UNIVERSIDADE de SÃo PAULO

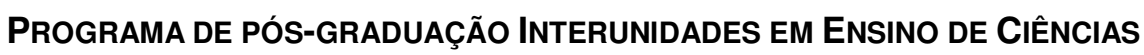

\title{
A IMPORTÂNCIA DA PERGUNTA NA PROMOÇÃO DA ALFABETIZAÇÃO CIENTÍFICA DOS ALUNOS EM AULAS INVESTIGATIVAS DE FÍSICA
}

VITOR FABRÍcIO MACHADO SOUZA 


\section{A IMPORTÂNCIA DA PERGUNTA NA PROMOÇÃO DA ALFABETIZAÇÃO CIENTÍFICA DOS ALUNOS EM AULAS INVESTIGATIVAS DE FÍSICA}

VITOR FABRÍCIO MACHADO SOUZA

DisSERTAÇÃo APRESENTADA AO INSTITUTO DE FísICA, INSTITUTO dE QUímICA, INSTITUTO DE BIologia e À FACULdAdE de EducAÇÃo da UnIVersidade de São PaUlo para OBTENÇÃO DO TíTULO DE MESTRE EM ENSINO DE CIÊNCIAS.

Área de CONCENTRAÇÃo: ENSINO de FísICA

Orientadora: Prof ${ }^{A}$ Dr $^{A}$ lucia Helena SASSERON

SÃo PAULO

MARÇO 2012 
Autorizo a reprodução e divulgação total ou parcial deste trabalho, por qualquer meio convencional ou eletrônico, para fins de estudo e pesquisa, desde que citada a fonte.

FICHA CATALOGRÁFICA

Preparada pelo Serviço de Biblioteca e Informação do Instituto de Física da Universidade de São Paulo

Souza, Vitor Fabrício Machado

A importância da pergunta na promoção da alfabetização científica dos alunos em aulas investigativa de física. - . São Paulo, 2012

Dissertação (Mestrado) - Universidade de São Paulo. Faculdade de Educação, Instituto de Física, Instituto de Química e Instituto de Biociências

Orientador: Profa. Dra. Lúcia Helena Sasseron Área de Concentração: Ensino de Física

Unitermos: 1.Física (Estudo e ensino); 2. Alfabetização Científica; 3. Atos da linguagem; 4. Análise do Discurso.

USP/IF/SBI-002/2012 


\section{RESUMO}

MACHADO, V. F. A importância da pergunta na promoção da alfabetização científica dos alunos em aulas investigativas de Física, 2012. Dissertação (mestrado) - Instituto de Física e Faculdade de Educação da Universidade de São Paulo (USP).

O trabalho de pesquisa desenvolvido aqui visa a entender quais os tipos de perguntas feitas pelo professor em uma atividade investigativa de Física e quais os indicadores de alfabetização científica (SASSERRON, 2008) apresentados pelos alunos a fim de investigar como as perguntas podem influenciar na promoção da alfabetização científica. Buscamos desenvolver uma categorização dos tipos de perguntas feitas pelo professor em aulas investigativas e verificar de que forma essas perguntas podem auxiliar os alunos a desenvolver aspectos relacionados à alfabetização científica.

O entendimento sobre o que seja pergunta está circunscrito à dimensão discursiva (BAKHTIN, 2000; VYGOTSKY, 2000) como um instrumento dialógico na cadeira enunciativa; à dimensão epistemológica (BACHELARD, 2007) como uma forma de se buscar o conhecimento e se investigar o mundo que nos cerca; e à dimensão social e política (FREIRE, 1985) como uma forma de incitar a curiosidade e o questionamento não apassivado perante as contradições existentes no mundo.

A elaboração das categorias considerou os referenciais relacionados aos aspectos discursivos (MORTIMER e SCOTT, 2002) no que se refere às intenções do professor em suas intervenções junto aos alunos no curso de uma investigação. Considerou também o ciclo argumentativo (SASSERON, 2008) que os alunos apresentam durante as etapas de uma atividade investigativa. Por fim, considerou os trabalhos anteriores cujo foco da pesquisa também se centrava nas perguntas do professor em aulas de Ciências (PENICK, 2007; MARTENS, 1999; e HARLEN, 1996). As categorias dos tipos de perguntas feitas pelo professor são: perguntas de problematização, perguntas sobre dados, perguntas exploratórias sobre processo, perguntas de sistematização. Com essa categorização, buscamos analisar de que forma as perguntas do professor ocorrem em uma aula investigativa e quais os indicadores de alfabetização científica (SASSERON, 2008) apresentados pelos alunos em cada momento das aulas investigativas.

As aulas analisadas, que constituem nossos dados, são oriundas do trabalho de mestrado de Barrelo Jr (2010) e compõem-se de uma Sequência de Ensino Investigativo (SEI) 
desenvolvida por Brokington (2005) sobre a dualidade onda-partícula e o interferômetro de Mach-Zenhder.

Verificamos em nossa análise que a nossa categorização apresenta uma grande ocorrência nas aulas e que, para determinadas perguntas do professor, os alunos apresentam, majoritariamente, alguns indicadores específicos de alfabetização científica, formando assim pares de perguntas/indicadores característicos para cada momento da atividade investigativa. Verificamos também que as perguntas dos alunos podem exercer um papel duplo no curso da argumentação e da investigação. Elas podem, ao mesmo tempo, expressar indicadores de alfabetização científica e, pelo seu caráter dialógico inerente, estimular e provocar os demais alunos a outras reflexões.

Concluímos, por fim, que as perguntas em aulas investigativas têm um papel importante no desenvolvimento de aspectos da alfabetização científica dos alunos e podem, quando amplamente utilizadas pelos alunos e professor oferecer um ambiente mais dialógico e propício para a argumentação em sala de aula, tornando-se um rico instrumento dialógico para auxiliar na construção dos significados em atividades investigativas de Física.

Palavras Chave: pergunta, atividades investigativas, alfabetização científica, ensino de Física 


\section{ABSTRACT}

MACHADO, V. F. The importance of the question in the promotion of scientific literacy of students in investigative Physics classes, 2012. Dissertation (Master's Degree) - Institute of Physics e Education School - USP

The research developed here aims to understand what are the types of questions asked by a teacher in an investigative Physicsactivity and which indicators of scientific literacy (SASSERRON, 2008) presented by the students to investigate how the questions can influence the promotion of scientific literacy. We seek to develop a categorization of types of questions asked by the teacher in investigative classes and check how these questions can help students to develop aspects related to scientific literacy.

The understanding of what is a question is circumscribed to the discursive dimension (BAKHTIN, 2000; VYGOTSKY, 2000) as a dialogical instrument; to the epistemological dimension (BACHELARD, 2007) as a way to pursue knowledge and to investigate the world around us; and to the a social and political dimensions (FREIRE, 1985) as a way to incite curiosity and not passive questioning before the contradictions of the world.

Our elaboration of categories considered the referentials related to the discursive aspects (MORTIMER and SCOTT, 2002) regarding the intentions of the teacher in the student's speeches in the course of an investigation. It also considered the argumentative cycle (SASSERON, 2008) which students present during the stages of an investigative activity. Finally, considered the previous works also focused on the teacher's questions in Science classes (PENICK, 2007; MARTENS, 1999; e HARLEN, 1996). The categories of types of questions asked by the teacher are: problematization questions, questions about data, exploratory questions about process, systematization questions. With this categorization, we sought to analyze how the teacher's questions occur in an investigative class and which are the indicators of scientific literacy (SASSERON, 2008) presented by the students in each moment of the investigative classes.

The classes that make up our analyzed data come from a master thesis by Barrelo $\mathrm{Jr}$ (2010) and consist of a Sequence of Investigative Teaching (SEl, the initials in Portuguese) developed by Brokington (2005) on the wave-particle duality and Mach- 
Zenhder interferometer.

We found in our analysis that our categorization has a high occurrence in the classes and, for certain teacher's questions, the students present, mostly, some specific indicators of scientific literacy, thus forming pairs of questions/indicators characteristic of each moment of the investigative activity. We also noticed that the student's questions can play a dual role in the course of argument and research. They can, at the same time, express indicators of scientific literacy and, for their inherent dialogical character, stimulate and provoke the other students to further reflection.

We conclude, finally, that the questions in investigative classes have a important role in the development of aspects of scientific literacy and may, when widely used by students and teacher, provide an environment more dialogical and favourable to argumentation in the classroom, becoming a rich dialogical tool to assist in the construction of meaning in investigative Physics activities.

Keywords: question, investigative activities, scientific literacy, Physics teaching 


\section{SUMÁRIO}

\section{Introdução e Justificativa}

1.1 A pergunta como forma de conhecer e de questionar. .09

1.2 A pergunta como manifestação discursiva na forma de aprender Física.

\section{Referencial teórico da pesquisa}

2.1 que consideramos como pergunta?

\section{Referencial Teórico Metodológico de pesquisa}

3.1 A pergunta nas análises das interações discursivas em Ciências.

3.2 A construção de um instrumento de análise das perguntas em aulas problematizadoras de física.

3.2.1 As categorias existentes, os Aspectos Discursivos do Ensino Investigativo e a elaboração de uma nova categorização.

4. Metodologia de pesquisa.

4.1 A constituição metodológica e dos dados com base nas perguntas de Investigação. .50

4.1.1 Os limites dos dados e os procedimentos de conformação destes à análise.......52 4.1.2 Quais os tipos de perguntas feitas pelo professor em uma aula de Física em que os alunos resolvem um problema?. .53

4.1.3 Que tipo de contribuição as perguntas podem trazer para um ensino que vise à $A C$ ? .53

\section{Análise}

5.1. Aula 2: o nascimento da Física Quântica. .55

Momento 1: Organização da aula, lembrança das aulas anteriores e introdução da atividade.

Momento 2: Retomada e discussão de conceitos e fenômenos ópticos:

(interferência, efeito fotoelétrico)..

Momento 3: Investigando situações clássicas (luz sob ação da gravidade, interferência, efeito fotoelétrico, reflexão da luz) para aplicar um modelo explicativo. 
Momento 4: Problematização: Se os dois modelos clássicos não dão conta de explicar todos os fenômenos, o que deve ser a luz?.......................................67

5.1.1 Observações gerais acerca da aula 2 ......................................................... 71

5.2 Aulas 10: Interpretações da Mecânica Quântica................................................71

Momento 1: Introdução da aula, lembrança do experimento do interferômetro e das figuras de interferência observadas............................................................ 73 Momento 2: Exploração do fenômeno de interferência para o fótons individuais da experiência observada comparando as figuras formadas.......................................75 Momento 3: O problema da explicação para a interferência para um único fóton no interferômetro.

Momento 4: As quatro interpretações da mecânica quântica para a natureza da luz.

Momento 5: As explicações das quatro interpretações para o padrão de interferência para apenas um ùnico fóton.

Momento 6: sistematização as explicações das quatro linhas interpretativas para a interferência de um fóton e introdução da atividade.

5.2.1 Observações gerais acerca da aula 10.

6. Síntese interpretativa das análises .88

6.2 As Perguntas de Problematização e os Indicadores associados. .91

6.3 As Perguntas sobre dados e os Indicadores associados. .92

6.4 As Perguntas exploratórias sobre processo e os indicadores associados. .93

6.5 As Perguntas de sistematização e os indicadores associados .94

6.6 As perguntas dos alunos e suas contribuições na $A C$ .95

\section{Considerações finais} .103

7.1 Quais os tipos de perguntas feitas pelo professor em uma aula de Física em que os alunos resolvem um problema?. .105

7.2 Que tipo de contribuição as perguntas podem trazer para um ensino que vise a $A C$ ?. .105

8. Conclusões .107

9. Referências Bibliográficas. 108

ANEXO A .114

ANEXO B 121

ANEXO C .136 


\section{Introdução e Justificativa}

1.1 A pergunta como forma de conhecer e de questionar

"Todo conhecimento é resposta a uma pergunta."

Gaston Bachelard

Você é capaz de ouvir o som de duas mãos batendo palma, mas qual o som de uma das mãos? Quem veio primeiro, o ovo ou a galinha? Por que "já" quer dizer agora e "já já" quer dizer daqui a pouco? O que é o que é, que nasce em pé e corre deitado? Um delicioso sorvete tem gosto nele mesmo ou na sua língua? Quem roubou pão na casa do João? Por que esse nariz tão grande, vovozinha? Oh, e agora, quem poderá nos ajudar? Com quantos paus se faz uma canoa? Qual o dobro de 5? Quem descobriu o Brasil? De onde viemos? O que você quer ser quando crescer? Para onde vamos? Uma árvore que caiu em um bosque desabitado emitiu som ao cair? Que mundo deixaremos para os nossos filhos? Que filhos deixaremos para o nosso mundo? Quem somos nós? O que é aquecimento global? Como surgiu a vida? O mundo vai acabar no apocalipse? Como surgiu o universo? O que é o amor? O que é Ciência? O que é Energia Escura? Existe éter? Por que um corpo cai? Ser ou não ser? Como aprender Física?

Poderíamos estender a lista de perguntas a muitas e muitas folhas caso retomássemos na memória as perguntas marcantes pelas quais se deteve cada um de nós durante nosso desenvolvimento da vida diária. Como bem expressou o escritor mineiro João Guimarães Rosa na obra Grande Serão Veredas (1988, p. 312):

"Vivendo, se aprende; mas o que se aprende mais é só a fazer outras maiores perguntas." (ROSA, 1988, p. 312)

Em um livro chamado "O que é a Pergunta?", voltado à introdução da filosofia para crianças, o filósofo contemporâneo Mário Sérgio Cortella expõe a seguinte passagem na fala de um personagem (professor de filosofia) para um menino questionador: 
"Perguntar é aceitar que não se sabe ainda alguma coisa e, com essa atitude, mostrar que se quer saber, em vez de fingir que já se sabe. Perguntar é a ponte que nos põe em contato com o novo, no lugar de ficarmos apenas repetindo o antigo. Perguntar leva até um território inédito a ser explorado, ou seja, a pergunta nos leva a terras desconhecidas, e, quando temos as respostas, ficamos mais cientes do mundo em que estamos. As respostas para alcançar curas de doenças, trazer ao mundo inovações e resolver problemas vieram das perguntas, e é desse modo que se criam novas soluções." (Cortella, 2008, p. 08)

O filósofo alemão e estudioso da linguagem Martin Heidegger (2008) considera que a linguagem é um dos elementos mais característicos da espécie humana pela capacidade de raciocinar. Para Heidegger, a pergunta é, senão a essência da razão, uma forma de inspecionar o mundo, conhecê-lo. E esse é um aspecto basilar também da natureza da Ciência, da investigação científica.

A premissa da pergunta como forma de se colocar diante do desconhecido e de abrigar o novo tornou-se familiar também à filosofia, ao positivismo, ao cientificismo e ao próprio espírito científico na construção de sua episteme. Para ilustrar o que queremos expressar, buscamos um exemplo concreto:

Em meados de 2009, mergulhadores australianos encontraram na costa de seu país um objeto não identificado (figura 1). A pergunta que se faz diante deste ente desconhecido é uma pergunta nem sempre falada em voz alta ou externalizada, mas muito provavelmente feita no interior do pensamento de quem o vê:

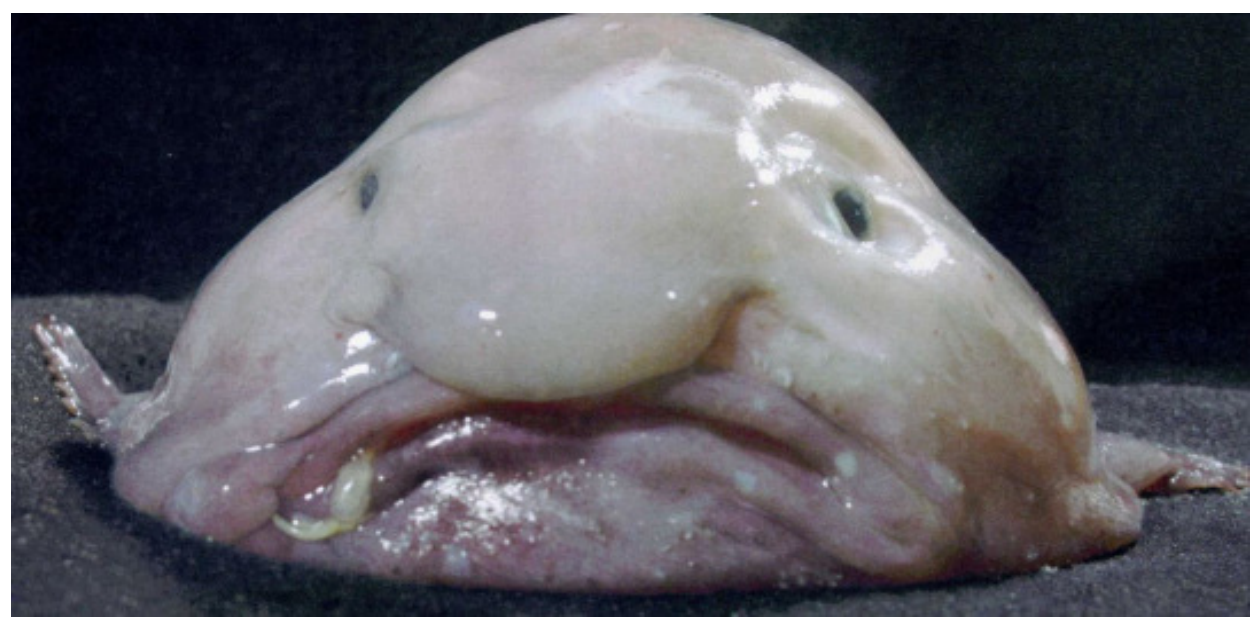

Figura 1: objeto encontrado na costa da Austrália

http://diariodebiologia.com/2010/12/blobfish-o-peixe-mais-feio-do-mundo/ 


\section{O QUE É ISSO?}

A Ciência é uma das formas pelas quais podemos responder a essa pergunta, e com os conhecimentos construídos em seus campos, pode se estabelecer um processo de investigação em que, diante do desconhecido, lançam-se perguntas como: Tem qual aspecto físico? É um ser vivo? Tem funções de organismos vivos? Que tipo de espécie pode ser? Estes são exemplos de perguntas, entre outras tantas, para que se chegue a um veredicto acerca da classificação daquele ente.

Guardadas as devidas proporções dessa descrição - até certo ponto grosseira -, esse exemplo se aproxima de um processo de investigação científica em sua natureza. Em decorrência disso, a cada pergunta lançam-se métodos, experimentos e teorias para saber quando se trata de um ser vivo, quais as suas características e que tipo de classificação pode ser-Ihe atribuída. Perguntar é parte da construção do conhecimento e o empreendimento humano chamado Ciência se vale de suas lógicas, seus métodos e seus empirismos para explorar as perguntas que emanam do imenso desconhecido que é o mundo. A pergunta é, portanto, um objeto epistêmico, ou como expressou Bachelard: "Todo conhecimento é resposta a uma pergunta" (2007, p. 12).

Quando falamos de conhecimento não nos restringimos à produção de conhecimento em seu fazer científico, artístico ou filosófico. Falamos também de onde o conhecimento se transmite, do espaço em que o conhecimento é experimentado e da escola como lugar em que este é apreciado, buscado, provocado. A sala de aula é um ambiente dinâmico no que se refere às interações entre alunos e seus pares, alunos e professores, e alunos e professores com os objetos de aprendizagem. O psicólogo russo Alexei Nikolaevich Leontiev contribui para essa reflexão em sua Teoria da Atividade na medida em que discute o psiquismo humano e as atividades, ações e operações realizadas pelo ser humano. Segundo compreendemos, os estudantes, quando se engajam em uma atividade, são estimulados por uma necessidade, um motivo. Isso os mobilizará na realização de uma ação. Essa ação, tanto para o investigador quanto para o aluno, pode ser a ação de perguntar. $O$ motivo dá sentido à atividade humana desenvolvida e a atividade de aprender demanda uma multiplicidade de motivos, ações e operações.

Em um debate aberto entre o educador Paulo Freire e o filósofo Antônio Faundez posteriormente compilado em um livro chamado "Por uma pedagogia da pergunta", no qual ambos discutem diversos temas da educação na América Latina-, o primeiro dirá que um dos grandes atributos do estudante é a sua inquietação, a sua dúvida, a sua 
curiosidade e estas devem ser tomadas pelo professor como desafios. Em um mimetismo teórico podemos arriscar que, para Freire, um dos grandes "motivos" (no sentido expresso por Leontiev) condutores na busca pelo aprendizado é a inquietude, a curiosidade. Para além dos motivos, Freire entra em uma busca pela "pedagogia da pergunta", na qual esta manifesta, sobretudo, a inquietude do aluno e seu engajamento em conhecer e questionar as coisas do mundo e os seus mecanismos. E não se trata apenas disso: perguntar é também uma forma de engajamento político, pois desestrutura o pilar do autoritarismo instaurado na escola e na sociedade contemporânea. É uma das formas de se tornar crítico e estabelecer novas formas de conduta perante a vida. Nas palavras de Freire:

\begin{abstract}
"A curiosidade do estudante às vezes pode abalar a certeza do professor. Por isso é que, ao limitar a curiosidade do aluno, a sua expressividade, o professor autoritário limita a sua também. Muitas vezes, por outro lado, a pergunta que o aluno, livre para fazê-la, faz sobre um tema, pode colocar ao professor um ângulo diferente, do qual the será possível aprofundar mais tarde uma reflexão mais crítica." (1985, p. 23)
\end{abstract}

Lorencini (1994), em uma pesquisa sobre a formulação de perguntas em sala de aula, faz um levantamento dos trabalhos sobre esse tema e destaca, entre outros objetivos, o estímulo à curiosidade dos estudantes. Em suas palavras:

\begin{abstract}
"A utilização de perguntas em sala de aula tem como principais objetivos aqueles que aparecem dispersos nos trabalhos de Mello Carvalho (1972), Harley (1973), Cols (1977), Sant'anna (1979) e Nérici (1989), e que podem ser resumidos a seguir: estimular a curiosidade e a capacidade criativa dos alunos; aumentar 0 interesse e a motivação para o conhecimento; desenvolver raciocínio, o senso crítico e a autoconfiança dos alunos; introduzir novos conceitos e manter a atenção dos alunos." (Lorencini, 1994, p. 107)
\end{abstract}

Defendemos a busca por um ambiente em que as perguntas são bem-vindas, tanto como forma de buscar o conhecimento, quanto como forma de estabelecer novas relações com os objetos de aprendizagem e como um engajamento mais questionador em relação ao mundo. Neste trabalho, quando falamos em perguntas do professor de Física em aulas investigativas de Física, incorporamos o fazer científico contido na construção do conhecimento Físico, as atividades problematizadoras e o espírito questionador dos alunos diante das questões e problemas que lhes aparecem. Isso faz com que os seus motivos os conduzam a uma busca coletiva da aprendizagem e da forma de ver o mundo da Física. Problematizar é possibilitar ao estudante criar, pensar, 
explorar toda e qualquer forma de conhecimento e objetos de seu pensamento na busca pela solução. O espaço de sala de aula é um espaço de construção coletiva onde os significados são estabelecidos. Esse processo de significação é também parte importante do trabalho ao olharmos as perguntas em sala de aula, pois o professor, em sua ação discursiva, pode auxiliar e modificar o curso de aprendizagem dos alunos.

\subsection{A pergunta como manifestação discursiva na forma de aprender Física}

Aprender é uma experiência primordialmente coletiva. De acordo com o psicólogo russo Lev Vygotsky (2000), é por meio das interações com os outros, com os pares e com os mais experientes que o conhecimento se constrói. Para nós, esse conceito de interação revela um traço tipicamente humano, que é a capacidade de articular a linguagem para produzir essas interações. E a linguagem não é um ente solitário, mas sim um conjunto de representações e formas de expressão que é construído e significado no seio da interação social.

Vygotsky (2000) expõe em seu livro "Pensamento e linguagem" que: "o homem, enquanto dá forma à natureza, confere significação à forma nova, o que the permite transformar a si próprio" (p. 103). Para o círculo de estudo do também russo Mikhail Mikhailóvitch Bakhtin (2009), filósofo da linguagem de filiação marxista, em seu livro "Marxismo e filosofia da Linguagem", "A palavra é resultante de um consenso entre indivíduos socialmente organizados, sua forma é condicionada tanto pelas relações sociais quanto pelas interações” (p. 99). Para os autores, há uma relação íntima entre o desenvolvimento da linguagem e o desenvolvimento do pensamento, ou seja, é por meio da estruturação da linguagem que se concebe um significado, e é por meio das articulações desses significados que a aprendizagem se dá em relação ao mundo. Esse pensamento é amplamente discutido desde meados da década de 1960, com uma linha de conduta pedagógica chamada "construtivismo" de caráter sócio-interacionista, exatamente pela necessidade de os sujeitos colocarem suas linguagens em torno de um objeto de conhecimento e negociarem os significados para ele.

Concebendo a sala de aula como um ambiente rico para possibilitar as significações e as construções conceituais, as perguntas dos alunos e/ou dos professores se encaixam nesse ambiente como inerentes à própria forma de se buscar o 
conhecimento. Para nossa pesquisa, entretanto, devemos precisar como acontecem essas interações e como entendemos a pergunta circunscrita ao ensino de Física e ao ensino de Ciências. Desse delineamento emerge a necessidade de estudar as interações discursivas que ocorrem em sala de aula, a forma como alunos e professores constroem um sentido para um conceito e como as perguntas participam desse movimento de aprendizagem.

A educadora brasileira Isabel Martins (1999) expõe que aprender Ciências exige o emprego de uma pluralidade de meios de comunicação de forma coordenada e a construção de novas significações resulta também da interação dos diversos sistemas de representação. Para ela, a forma de se conseguir essa pluralidade de meios de comunicação em sala de aula passa necessariamente pela interação entre os sujeitos envolvidos. Para que isso ocorra, as atividades implementadas devem privilegiar as discussões, os debates, as exposições de ideias e percepções dos alunos diante de um conceito ou fenômeno. Em suma, devem ser problematizadoras.

O professor tem papel importante em problematizar o conteúdo e incentivar o uso da linguagem científica em seu trabalho docente. Em concordância com esses pressupostos amplamente estudados nesta pesquisa, buscaremos explorar a pergunta feita pelo professor na construção dos conceitos em uma forma problematizadora e participativa de aprender Física. A pergunta pode ser tomada como objeto epistêmico do conhecimento e, além disso, uma ferramenta discursiva capaz de provocar os alunos e ajudá-los a desenvolver habilidades no modo de pensar da Física. Por isso, entendemos que a pergunta deve ser melhor entendida.

Como parte do léxico cotidiano, fazemos perguntas a vida inteira, ouvimos perguntas, falamos, pensamos por meio do conjunto semiótico do nosso sistema de comunicação. É preciso salientar, entretanto, que o professor, na condição de agente promotor da aprendizagem, na forma como concebemos o ensino da Física, deve levar a ação de perguntar aos seus alunos como dotada de uma consciência.

Ao perguntar, o professor pode ou não ter a consciência do seu intento com a ação. E para a sala de aula, esse intento deve remeter aos objetivos pedagógicos na construção de conhecimento, ou seja, àquilo que é pretendido na atividade, como aprendizagem para os alunos. Entretanto, a ação consciente de perguntar, alicerçada nos objetivos pedagógicos, muitas vezes acaba por tornar-se uma operação (LEONTIEV, 1978): um ato automático, desprovido de consciência, realizado comumente como outras tantas operações diárias, como escovar os dentes, escrever na lousa ou fazer a chamada. 
E, quando há uma operação sem consciência, Leontiev caracteriza isso como alienação.

Em um estudo quantitativo voltado para a verificação das ocorrências de perguntas em aulas de Física, Hargie (1983, apud MENEZES, 1996) observou as aulas de diferentes professores em seis classes de séries equivalentes ao nosso Ensino Médio e verificou que esses professores fazem, em média, uma pergunta a cada 72 segundos quando discursam. Destas, 38\% não são respondidas pelos alunos e a maioria implica somente no resgate da memória, sendo que somente a minoria demanda reflexões para a construção de novos saberes. A pergunta se torna uma operação corriqueira para confirmar algo, ou alguma forma de vício no discurso do professor.

Ademais, as pesquisas em ensino ainda têm subsidiado pouco a prática dos professores com relação a essas interações de sala de aula, de modo que estes continuam realizando perguntas em suas aulas de forma operacional. Sob esse aspecto, Carvalho e Gil-Pérez (1998) indicam algumas ideias de senso comum tidas por professores, oriundas muitas vezes da própria vivência escolar e que colaboram para uma visão simplista e tradicional do ensino. De acordo com os autores, existem concepções espontâneas por parte dos professores, como a percepção de que ensinar é fácil ou que é uma mera transmissão de conhecimentos e conteúdos; também indicam a existência de um pensamento entre alguns professores de que, em sala de aula, o professor é o centro do conhecimento e, portanto, invoca discursos solitários sob aspectos do conteúdo que não tomam sentido. Suas perguntas acabam, na maioria das vezes, sendo respondidas por eles mesmos, não se configurando, portanto, num processo dialógico (BAKHTIN, 2000).

Esse tipo de automatismo, em que o professor responde a si mesmo, pode ser visto como cultural. Jiménez-Aleixandre et al (2000) apontam para o "fazer escola", no qual professores e alunos se encaixam em uma série de comportamentos e normas, ambos isentos de reflexão. Por vezes, os alunos entendem, devido ao modo como sua experiência escolar foi co-construída, que eles devem fazer o que o professor quer. $E$ em uma cultura escolar com grande ênfase em resolução de exercícios e com poucos problemas, os alunos tendem a aplicar técnicas, normalmente relacionadas ao conteúdo desenvolvido naquele momento. Essa cultura escolar, impregnada na formação do aluno desde o início, faz com que ele pare de questionar, ou seja, desestimula a pergunta em sala de aula. Na mesma linha, Yore et al (2003) indicam que as crianças no início de sua vida escolar realizam muitas perguntas sobre todas as coisas que estudam, e durante a escolaridade perdem o hábito de perguntar, se centrando na obtenção de respostas ou 
nos produtos finais do conhecimento.

Pensamos e buscamos neste trabalho uma forma diferente de encarar 0 aprendizado em Física, pautada nas ações questionadoras dos alunos e dos professores, em um processo de investigação e de problematização, visando à alfabetização científica $(\mathrm{AC})^{1}$. Essa visão e defesa do ensino de Física se faz presente e importante neste contexto contribuindo para uma formação questionadora, investigativa, argumentativa e crítica, características centrais do fazer Ciência. E é por meio dessa forma do fazer científico ou cultura científica que entendemos o estudo da pergunta como pertinente à formação de cidadãos.

No trabalho de investigação aqui apresentado buscamos coerência com a linha de pesquisa do nosso grupo de pesquisa - LaPEF ${ }^{2}$ - e de outros grupos cujos trabalhos estão direcionados para a análise das interações discursivas em contextos formativos. Buscamos um ensino de Física no qual os alunos participem de forma ativa da construção de seus conhecimentos, saibam argumentar e se posicionar diante de um problema e saibam analisar e diferenciar argumentos no seu dia a dia, características necessárias e que devem ser trabalhadas com os alunos se almejamos a alfabetização científica.

Analisando as interações discursivas em aulas de Física em que os alunos resolvem um problema por investigação, nosso objetivo nesta pesquisa é compreender como as perguntas ocorrem; qual é o seu papel nas interações; verificar a ocorrência em aulas de Física; entender como elas podem promover a argumentação dos alunos; subsidiar a alfabetização científica; e categorizá-las com base nesses pressupostos.

E se propomos uma investigação sobre a pergunta, se faz necessário explicitar nossas perguntas de pesquisa centrais, que nos porão em frente ao novo e ao desconhecido, que nos moverão ao processo de busca aqui apresentado. E nossas perguntas são: Quais os tipos de perguntas feitas pelo professor em uma aula de Física em que os alunos resolvem um problema? Que tipo de contribuição as perguntas podem trazer para um ensino que vise à $A C$ ?

\footnotetext{
Neste trabalho, os referiremos ao termo "alfabetização científica" também com a sigla AC

2 LaPEF: Laboratório de Pesquisa em Ensino de Física da Faculdade de Educação da USP.
} 


\section{Referencial teórico da pesquisa}

\subsection{O que consideramos como pergunta?}

"Pergunta tão rica, precisava andar por aí mendigando por respostas?"

Paulo Leminski

Diante do discorrido na introdução, e considerando os sentidos atribuídos socialmente à palavra "pergunta", esta pode apresentar um caráter polissêmico e muitas vezes ser confundida como sinônimo de outras palavras da língua portuguesa como, por exemplo, a palavra "questão"; e pode ser confundida pelos próprios estudos acadêmicos sobre interações discursivas com os termos "enunciação" ou "iniciação". Cientes dos sentidos próximos usuais na vida cotidiana entre as palavras "pergunta" e "questão" defenderemos que a primeira será o objeto conceitual do trabalho e a segunda representará o espírito indagador e questionador ao qual Paulo Freire (1985) se refere e que incorporamos como parte da formação do educando.

As origens etimológicas, apesar de descentralizadas de seus contextos sociohistóricos de significação, oferecem uma forma diferente de ver as palavras envolvidas na pesquisa. Em uma consulta, ali por volta do $P$ e do $Q$ encontramos as seguintes origens para as palavras:

- Questão - substantivo feminino. Do latim, quaestionem. A questão. Negócio, pendência, demanda, briga, disputa, controvérsia. (BUENO, 1966, p. 3299)

- Pergunta - Substantivo feminino: Variação, preguntar. Do latim percontari, verbo da linguagem náutica significando sondar a profundidade dos mares para julgar o calado e evitar que o navio encalhasse. (BUENO, 1966, p. 2975)

Não devemos considerar as definições como cabais à nossa pesquisa, pois em dado momento as origens das palavras tiveram sentidos diferentes. Das línguas oriundas majoritariamente do Latim, como o Português, o Espanhol, o Catalão, o Galego, o Francês, o Italiano e o Romeno, apenas as três últimas não têm em seu idioma uma raiz 
próxima de "percontari". O Francês e o Italiano usam a questão como sinônimo e o romeno, por ser uma língua muito influenciada por outras, traz uma outra palavra.

Há, como podemos ver, uma pequena diferença nessas duas palavras na forma como as entendemos hoje e como elas se constituíram. As duas têm raízes linguísticas no Latim, uma das línguas-mãe do Português e fundamentalmente difundida durante o Império Romano. Atreladas à cultura, as duas encontram ligação nos modos e costumes desse povo, o que faz delas pouco distintas entre si. Quaestionarem surge como "a questão" (com o artigo antecedendo), a questão a ser resolvida, a pendência, o problema, sentido ainda hoje utilizado e que tomaremos para referir a uma ação questionadora, não passiva. A associação entre a questão para se resolver e um debate decorrido de tal questão deve ser salientada, de modo que questionar é também provocar o debate em torno da questão. Por sua vez, perguntar, no Latim, é investigar se o mar está fundo o suficiente para navegar. Esse sentido atrelado à navegação se assemelha ao processo de investigação acerca do desconhecido na medida em que expõe procedimentos para se descobrir algo oculto. É um método de investigar a profundidade, um diagnóstico; busca conhecer algo não evidente e, nesse sentido, se aproxima muito mais da pergunta como manifestação da natureza epistemológica. A pergunta propulsora para o conhecimento, que abre espaço para a investigação.

Esta não é uma justificativa baseada somente na etimologia. Trata-se de uma diferenciação dos sentidos que usaremos para as palavras "pergunta" e "questão" neste trabalho. O sentido da palavra "pergunta", o qual tomaremos como conceito, ganha uma nova forma e significado no seio da investigação que propomos e é preciso buscar o contexto em que estamos para assim ressignificá-la diante do ensino investigativo de Física e das interações discursivas em sala de aula.

\subsection{Ressignificando a pergunta}

No sentido buscado para a pergunta neste trabalho, o filósofo da linguagem russo Bakhtin tem um papel central no entendimento da pergunta na medida em que elaborou, junto com os colegas de seu círculo de estudos, duas unidades imprescindíveis para compreender a linguagem e a formação de significados: a teoria da enunciação e do conceito de dialogia.

Para Bakhtin e seus colaboradores as palavras carregam consigo signos que, na 
interação sócio-histórica, representam significados compartilhados. Como os sujeitos que compartilham o mesmo código significam as palavras ao longo da vida e da aprendizagem, e aprendem também a pensar por meio desses signos, nasce daí uma dicotomia natural entre o pensamento, ou fala interna, e as generalizações, ou falas externas. A fala interna é silenciosa, articula a própria consciência humana e é intermediada pelos signos. A fala externa representa um consenso entre os indivíduos socialmente organizados. Quando o sujeito fala ou externaliza, ele o faz por meio de palavras e se vale da situação em que se expressa. Nesse sentido, ele emite um enunciado. E nas palavras de Bakhtin: "enunciado é a forma na qual a palavra transita entre o interno e a situação social' (2009, p. 79).

A teoria da enunciação diz que um enunciado é o modo principal pelo qual as pessoas se comunicam, pois quaisquer interações verbais, e também aquelas em sala de aula, consideram um fluxo de enunciados ou uma cadeia enunciativa. Para que um enunciado seja compreendido pelo ouvinte, ele deve conferir um significado orientado pelo horizonte conceitual de quem fala considerando as palavras e signos de quem diz e de quem ouve. Acostumamo-nos a ouvir expressões no universo da sala de aula ou no convívio social como: "o professor sabe muito, mas não conseguimos compreender o que ele fala" ou "eu disse uma coisa e você entendeu outra". De certa forma, este empirismo cotidiano nos revalida essa Teoria da Enunciação no comum e popular, pois muitas vezes a mesma enunciação em uma conversa não tem o mesmo significado para a pessoa que fala e para a pessoa que ouve. Cada indivíduo constrói uma gama de significados para as palavras ao longo da vida e nas enunciações elas precisam ser reconstruídas. Por essa razão devemos introduzir o segundo conceito importante de Bakhtin: o de dialogia.

Percebamos que uma relação de troca enunciativa constitui um diálogo. Um diálogo considera o escopo de significados construídos sociohistoricamente por cada indivíduo no momento de uma interação. Cada sujeito atribui à sua fala um sentido, e quando as pessoas dialogam, esses sentidos e signos contidos nos enunciados estão sendo trocados.

Bakhtin chama de "voz" essa expressão do discurso interno. E em uma cadeia enunciativa como a de sala de aula, dependendo do contexto em que se criam, os significados contidos nas vozes vão evoluindo e se reconstruindo. Por isso dissemos linhas acima que precisamos apresentar o contexto de nossa pesquisa para ressignificarmos a palavra "pergunta". Nos termos propostos por Bakhtin: 
"compreender a formação dos contextos implica adotar o ponto de vista de várias vozes para perscrutar as formações enunciativas de cada um de seus participantes e identificar como evoluem os sentidos e os significados nos seus universos." (2009, p. 121)

Um importante dado desses conceitos propostos por Bakhtin em relação à enunciação e à dialogicidade é que, por a fala ser interna e externa, todo enunciado irá, necessariamente, esperar uma resposta do interlocutor. Ou seja, quando realizamos um enunciado em um diálogo, as nossas palavras causam aos nossos ouvintes um estímulo do discurso interno no processo de compreensão do que foi dito. Isso retrata um problema nem sempre notado em sala de aula, em que muitas vezes o aluno não fala em uma discussão ou cadeia discursiva em andamento, mas as vozes emergentes lá podem the causar um diálogo interno provocado pelos enunciados. Mesmo que os enunciados NÃO se constituam de perguntas, podem causar uma resposta ao ouvinte. Aqui, podemos diferenciar o enunciado de uma pergunta.

De acordo com Bakhtin (2009), uma pergunta pertence à esfera do enunciado. Ele se refere à "questão completa" com modo da enunciação. Nesse sentido, a enunciação presente na pergunta é uma iniciação à cadeia enunciativa que contém, mais que as outras, um caráter responsivo. Esse conceito de responsividade é importante e faz parte do caráter dialógico do discurso defendido por Bakhtin. Toda conversa pressupõe uma cadeia enunciativa e o caráter responsivo dos enunciados significa que sempre causarão ao interlocutor a busca por uma resposta que continue a cadeia. Por mais que um professor em sala de aula faça uma avaliação positiva cabal sobre certa colocação, as enunciações podem prosseguir na cabeça dos alunos em um diálogo com seu pensamento. A voz do discurso do locutor ressoa e se mistura ao pensamento do aluno em um diálogo interno.

Embora o caráter responsivo seja inerente à enunciação, faz-se necessário diferenciar responsividade de resposta a uma pergunta: responsividade decorre de uma interação verbal dialogando as vozes presentes, ou seja, em uma cadeia enunciativa, ao se ouvir a fala do interlocutor, há uma responsividade na assimilação das informações e uma articulação interna que pode virar uma fala externa; já a resposta a uma pergunta é a fala externa (repleta de signos). Para nós, em consonância com Bakhtin, a pergunta se diferencia do enunciado pelo seu propósito, e nesta pesquisa o propósito é considerado didático. Desse modo, podemos considerar neste trabalho a seguinte definição de pergunta por nós elaborada. 


\section{Trata-se de um instrumento dialógico de estímulo à cadeia enunciativa. Sendo assim usado com propósito didático dentro da história da sala de aula para traçar e acompanhar a construção de um significado e de um conceito.}

Devemos ressaltar três palavras imprescindíveis contidas nessa definição para cercar o sentido da pergunta utilizado neste trabalho: estímulo, instrumento e propósito. Ao apontarmos estímulo, estamos enfatizando que, para além da simples enunciação, a pergunta deve necessitar de um estímulo à resposta. E este pode levar a uma reflexão ou externalização da resposta. É, portanto, uma característica muito marcante da pergunta sob o ponto de vista da teoria da enunciação.

Quando falamos em instrumento e propósito, nos apropriamos dos trabalhos do pesquisador norte americano James Wertsch, cuja obra nasceu da convivência com os grupos de neovigotskiano e neobakhtinianos na Rússia e também com os estudos de Leontiev em sua Teoria da Atividade. Em seu livro "Mente e ação" (1978), Wertsch lança a Teoria da Ação Mediada que congrega os princípios de Vygotsky, Bakhtin e Leontiev. Wertsch olhará para os aspectos semióticos das enunciações e, principalmente, para o processo de internalização. Os sujeitos internalizam os significados contidos nas enunciações por meio de ferramentas culturais e do diálogo incessante das vozes presentes no contexto. O processo de significação, além da interanimação de vozes dentro dos enunciados, ocorrerá por meio de ferramentas emprestadas de um grupo social e, portanto, sujeitas ao rumo histórico-cultural da situação.

Para ele, a ação tem cinco características importantes: 1) o propósito - qual o motivo da ação, o que se quer com ela; 2) o cenário da ação - qual o lugar, o auditório e o contexto; 3) quem é o agente - quem fala, sua voz; 4) qual é a ação - sua natureza e característica; e 5) quais as ferramentas usadas na ação. A colocação e a visão de "ferramenta", "ação" e "propósitos” presentes no trabalho de Wertsch traz uma valorosa contribuição no sentido da definição da pergunta como será trabalhada em nossa pesquisa.

A pergunta compreende aqui um estímulo ainda maior da cadeia enunciativa em um contexto didático. Na visão de Wertsch, a fala e a pergunta são ações, e a palavra é 
uma ferramenta. O propósito da ação intencional de perguntar é muito importante, pois é ele que evidencia o que se pretende. A cena, o agente, o ato e a ferramenta estão circunscritos também nessa ação, mas a característica didática da pergunta em sala de aula impõe um propósito à ação de perguntar. Nesse sentido, deve-se considerar a relevância ao se tratar das perguntas. E, se consideramos o propósito da ação de perguntar nos termos definidos até aqui, devemos responder também, para esta pesquisa, quais são os nossos propósitos, o que pretendemos em um ensino de Física para que possamos estudar a pergunta dentro deste prisma constituído da nossa visão de ensino e educação.

2.3 0 ensino Investigativo de Física, a alfabetização científica e a pergunta

"No fundo, é correta a atitude de quem não se sente dono da verdade nem tampouco objeto acomodado do discurso alheio que Ihe é autoritariamente feito. Atitude correta de quem se encontra em permanente disponibilidade a tocar e a ser tocado, a perguntar e a responder, a concordar e a discordar. Disponibilidade à vida e a seus contratempos. Estar disponível é estar sensível aos chamamentos que nos chegam, aos sinais mais diversos que nos apelam, ao canto do pássaro, à chuva que cai ou que se anuncia na nuvem escura, ao risco manso da inocência, à cara carrancuda da desaprovação, aos braços que se abrem para acolher ou ao corpo que se fecha na recusa. É na minha disponibilidade permanente à vida a que me entrego de corpo inteiro, pensar crítico, emoção, curiosidade, desejo, que vou aprendendo a ser eu mesmo em minha relação com o contrário de mim. E quanto mais me dou à experiência de lidar sem medo, sem preconceito, com as diferenças, tanto melhor me conheço e construo meu perfil."

Paulo Freire

$\mathrm{Na}$ defesa e justificativa deste trabalho, destacamos a pergunta como objeto epistêmico na busca pelo conhecimento, como objeto discursivo no processo de significação de um conceito, e como forma de questionar o mundo e levar a uma formação crítica. Esse traço concernente à formação crítica está presente na forma como 
enxergamos a formação de um sujeito. Os propósitos formativos são características cruciais, às quais se reportam o comportamento discursivo do professor em sua ação de perguntar.

O educador Paulo Freire em seu livro "Pedagogia da Autonomia" (2007) traça uma defesa contundente da formação autônoma do educando para a compreensão crítica do mundo. Em suas palavras, o professor, em sua ação docente, deve primar pela curiosidade, pelo diálogo, pela criticidade, pelo sentido ideológico.

Acreditamos nesses princípios como forma de educar para uma emancipação intelectual, para um engajamento no mundo consciente de suas desigualdades, suas mazelas sociais. Tais características destacadas por Freire são promotoras do desenvolvimento de uma curiosidade crítica, insatisfeita, indócil. Curiosidade com que podemos investigar e nos defender dos "irracionalismos" decorrentes ou produzidos por certo excesso de "racionalidade" de nosso tempo.

O professor deve estimular a pergunta, a curiosidade contida nela e a reflexão crítica sobre a própria pergunta. Deve saber o que se pretende com esta ou com aquela pergunta em lugar da exposição excessiva. A atividade docente deve buscar a curiosidade no lugar do "puro vai-e-vem de perguntas e respostas, que burocraticamente se esterilizam" (FREIRE, 2007, p. 84).

Guardando uma similitude de idéias com Bakhtin, mesmo tendo desenvolvido trabalhos independentes, Paulo Freire - também considerado por muitos um materialista dialético - considera também o sentido da dialogicidade dizendo que esta não nega a validade de momentos explicativos em que o professor expõe ou fala sobre algo. Para ele, para além do sentido do diálogo de fala interna, a dialogicidade é, sobretudo, uma condição de igualdade, uma postura dialógica entre professor e alunos, aberta, curiosa, indagadora e não apassivada, enquanto fala ou enquanto ouve. O que importa é que professor e alunos se assumam epistemologicamente curiosos. "O bom professor", defende ele:

"...é o que consegue, enquanto fala, trazer o aluno até a intimidade do movimento de seu pensamento. Sua aula é assim um desafio e não uma 'cantiga de ninar'. Seus alunos cansam, não dormem. Cansam porque acompanham as idas e vindas de seu pensamento, surpreendem suas pausas, suas dúvidas, suas incertezas. Antes de qualquer tentativa de discussão de técnica, de materiais, de métodos para uma aula dinâmica assim, é preciso, indispensável mesmo, que o professor se ache 'repousado' no saber de que a pedra fundamental é a curiosidade do ser 
humano. É ela que me faz perguntar, conhecer, atuar, mais perguntar, reconhecer." (FREIRE, 1985, p. 84)

Cremos que a Física e as Ciências como áreas do conhecimento humano devam servir a esses propósitos também; devam possibilitar uma forma de leitura do mundo que ofereça possibilidades de olhar, entender e questionar os empreendimentos científicos e tecnológicos e suas relações sociais e ambientais na sociedade de hoje. $\mathrm{O}$ ensino de Ciências deve servir como meio de investigação, possibilitando habilidades do pensar científico que promovam uma criticidade indócil como forma de pensar um problema, de elaborar hipóteses e justificativas, de usar a argumentação como capacidade de expressão da opinião e de convencimento.

$\mathrm{Na}$ literatura da área, este modo de olhar o ensino de Ciências que estamos buscando encontra convergência na perspectiva de um ensino chamada de alfabetização científica, ou enculturação científica, ou letramento científico, de acordo com traduções ou discussões semânticas das escolas de pensamento. Para nós, a escolha do termo alfabetização científica se dá pela proximidade com o sentido de alfabetização defendido por Paulo Freire e do qual nos apropriamos. Para ele, a alfabetização empreende um domínio consciente de algo e resulta em uma autoformação e uma postura interferente do homem em seu contexto (FREIRE, 2007). Esse conceito foi usado por Freire para a alfabetização de adultos nos processos de escrita e leitura. Entendendo as Ciências como uma forma de ver e agir no mundo, alfabetizar cientificamente é possibilitar este processo no qual, por meio das Ciências, se interfere e se conhece o que nos rodeia.

A alfabetização científica vê o ensino sob uma perspectiva problematizadora e participativa, em que os alunos utilizam habilidades típicas das Ciências, ou seja, uma forma científica de pensar para intervir no mundo. $O$ alfabetizado cientificamente, assim como qualquer cientista, não precisa saber tudo sobre as ciências, mas deve ter conhecimentos suficientes de vários campos delas e saber como esses estudos se transformam em adventos para a sociedade. Ao mesmo tempo, ele é influenciado pelas relações políticas, buscando compreender de que modo tais conhecimentos podem afetar sua vida e a do planeta, e participa das discussões dos problemas que afetam a vida e a sociedade.

Esse sentido problematizador aparece em nosso trabalho de forma basilar no entendimento da ação de questionar e perguntar. Buscaremos, do ponto de vista didático, os pressupostos de que a ação de perguntar, conforme definida por nós, carrega consigo 
uma problematização. Este conceito de problema é melhor delimitado por Gil-Pérez et.al (1992), para quem um problema consiste de situações dificultosas, para as quais não existem soluções fechadas; uma situação, quantitativa ou não, que pede aos sujeitos envolvidos uma solução não evidente. Ainda para Gil-Pérez et al (op cit.), o modo pelo qual um cientista resolve um problema é pela investigação científica.

Pensamos que um ensino escolar cujo propósito seja a promoção da AC para alunos de qualquer um dos níveis da educação básica deve estar baseado em um currículo que permita o ensino investigativo, baseado em atividades problematizadoras das Ciências, levando os alunos a pensar sobre um problema, a criar estratégias e planos de ação para resolvê-lo e a organizar informações e conhecimentos novos e já existentes que Ihes permitam explicar fenômenos. Como nos lembra Vygotsky (2000), a construção do conhecimento se dá mediante as partilhas de significados, com a ajuda dos pares e do professor, de modo a diminuir a distância entre o que os educandos sabem previamente e o que conseguem resolver sem a ajuda de ninguém. Esta é uma parte do processo que Vygotsky dá o nome de zona do desenvolvimento proximal (ZDP). Assim, coletivamente, os estudantes avançam na construção de um conhecimento novo. Uma atividade problematizadora coloca em jogo as concepções prévias dos alunos, um problema motivador de investigação e uma ação conjunta com auxílio do professor para buscar as formas e meios de resolvê-lo, chegando sempre a um novo significado compartilhado pelo grupo.

E é por meio da linguagem e das interações discursivas que professores e alunos constroem as bases para um ensino que privilegie a ciência como uma cultura e vise à alfabetização científica. Além disso, é importante ressaltar que a adoção dos referenciais sobre o uso de diferentes linguagens em sala de aula nos permite compreender de que modo a construção do conhecimento é mediada pelo professor. Contudo, parece-nos verdadeiro que a atenção às interações discursivas em sala de aula apenas faz sentido quando explicitamos quais são nossos objetivos com o ensino da Física nas salas de aula de Educação Básica. A aprendizagem científica é também um processo de transição dialógica de uma linguagem abstrata e comum para uma linguagem científica com suas características particulares. Sendo que as linguagens não são excludentes e sim complementares em vista de suas significações simbólicas.

"É apenas pela interação em curso que o professor e os alunos têm a oportunidade de comparar interpretações do que estão dizendo uns aos 
outros e, assim, aproximam-se gradualmente de significados funcionalmente equivalentes." (VYGOTSKY, 2000. P. 13)

Com um conjunto de linguagens específicas baseadas na lógica, na matemática, em gráficos, fluxos, entre outros elementos, a Física dialoga essas linguagens em torno de um fenômeno físico natural. E a apreensão e articulação destas faz parte também do processo de significação dado no seio do grupo em que são trabalhados os problemas do conhecimento físico. Nas palavras de Driver e Newton (1997), grandes expoentes da pesquisa em ensino de Ciências:

"A Ciência é muito mais do que um conjunto de conteúdos específicos ordenados em teorias. Ela deve ser entendida como uma cultura, que tem regras, valores e linguagem próprias." (DRIVER e NEWTON, 1997, p. 5)

A partir do fim da década de 1980, o estudo sobre as interações discursivas e da linguagem tem crescido em diversas áreas do conhecimento. No ensino de Ciências, são expoentes os trabalhos de Mortimer e Scott (2002), Lemke (1998), Driver e Newton (1997), Nascimento e Vieira (2009), Sasseron e Carvalho (2008), Roth (2003); Jiménez Alexandre et al (2000), Martins et al (1999); entre outros. Todas essas pesquisas acordam sobre a importância da linguagem e das interações discursivas em consonância com as perspectivas construtivistas de aprendizagem e com uma visão mais ampla sobre o sentido de se ensinar Ciência como uma cultura, como um modo de pensar e agir na sociedade - visão que se faz presente nos principais currículos mundiais de ensino de Ciências (RODRIGUES e BORGES, 2008).

Um conceito que se sobressai no bojo das investigações em ensino de Ciências com a perspectiva da alfabetização científica é o de argumentação. Trata-se de uma habilidade central propiciada também pelos saberes científicos e que promove ao aluno as condições de criticidade e reflexão acerca das questões problemáticas no campo do conhecimento e na vida social. A pesquisadora galega Maria Pilar Jiménez-Aleixandre, referência na pesquisa em ensino de Ciências, ressalta o raciocínio argumentativo como relevante para o ensino de Ciências, já que um dos fins da investigação cientifica é a geração e justificação dos enunciados e ações encaminhadas para a compreensão da natureza. Sendo assim, o ensino de Ciências deveria dar a oportunidade de desenvolver, entre outras, a capacidade de raciocinar e de argumentar. 
Lucia Helena Sasseron, pesquisadora dedicada às questões de argumentação em ensino e Ciências, destaca a argumentação como "todo e qualquer discurso em que aluno e professor apresentam suas opiniões em aula, descrevendo ideias, apresentando hipóteses e evidências, justificando ações ou conclusões a que tenham chegado, explicando resultados alcançados" (SASSERON, 2008, p. 53). Esta é uma forma de ampliar o diálogo que defendemos em sala de aula e um meio pelo qual o conhecimento físico pode auxiliar o desenvolvimento das habilidades argumentativas. É, sobretudo, o que buscamos como propósito no ensino de Física.

No trabalho de sala de aula, quando falamos em alfabetização científica na importância da problematização e da argumentação, estamos pensando e organizando tais perspectivas dentro de uma Sequência de Ensino Investigativo (SEI) - um conjunto ordenado de atividades investigativas planejadas com um problema a ser resolvido e que envolvem a argumentação no processo de construção do conhecimento.

Para Azevedo (2009), as atividades investigativas sucedem situações problematizadoras. Os estudantes devem se envolver na investigação; o problema posto, não é do professor, e sim dos estudantes, que devem perceber o problema e assimilá-lo de modo que a buscar procedimentos e novos conhecimentos com a ajuda do professor e de seus colegas. Esta é uma participação ativa do aluno em seu próprio processo de atividade.

Azevedo enumera uma série de vantagens e características das atividades investigativas, como: lidar com um problema; refletir a relevância dele; potencializar as análises qualitativas; elaborar hipóteses como forma de solução; analisar resultados; refutar hipóteses; ressaltar o papel da comunicação e do debate na construção científica; ressaltar a dimensão coletiva do trabalho científico. Como dissemos anteriormente, atividades investigativas em torno de um problema têm um grande potencial para promover a aprendizagem dos alunos em Ciências.

Utilizaremos neste trabalho o termo SEI para nos referir a essas atividades investigativas que promovem a alfabetização científica. A sigla foi cunhada no trabalho de Carvalho (2011), no qual a autora, buscando explicitar as formas como o sujeito constrói o conhecimento científico e como se constrói o conhecimento na escola, utiliza os referenciais piagetiano e vigotskyano, respectivamente, e enumera alguns aspectos fulcrais presentes em uma SEI: a participação ativa do estudante; a importância da interação aluno-aluno; o papel do professor como elaborador de questões; a criação de um ambiente encorajador; o ensino a partir do conhecimento que o aluno traz para a sala 
de aula; o conteúdo (o problema) como algo significativo para o aluno; a relação Ciência, Tecnologia e sociedade; e a passagem da linguagem cotidiana para a linguagem cientifica.

Considerando tais perspectivas para o ensino de Ciências, quando falamos em investigar a pergunta do professor em aulas investigas de Física (dentro de SEIs) estamos apostando em uma perspectiva de educação crítica, antes de tudo, em um ensino de Física que carrega o germe da alfabetização científica. Falamos também do potencial discursivo mobilizado em sala de aula e como o professor poderá lidar com sua ação discursiva de modo a aproximar os alunos da zona em que a construção dos significados e conceitos se dará. A pergunta tem, acima de tudo, um papel na promoção do ensino em que acreditamos: consonante com as mais diversas linhas de pesquisa mundiais e profícuo para a sociedade vigente, com uma possibilidade questionadora do mundo da mesma forma como se aceita a curiosidade epistemológica.

Antevemos, todavia, que, ao desenvolvermos uma categoria de análise para classificar e tipificar as perguntas feitas pelos professores em sala de aula, levamos, na sombra dessa categoria, nossos propósitos. Com essa base, será desenvolvida a pesquisa por nós proposta, na qual as categorias aqui elaboradas, as análises realizadas e as conclusões só poderão caminhar para uma visão de ensino como aquela apresentada neste trabalho. 


\section{Referencial Teórico Metodológico de pesquisa}

\subsection{A pergunta nas análises das interações discursivas em Ciências}

Como nosso objeto de pesquisa se configura na pergunta do professor em aulas investigativas de Física, devemos retomar na literatura específica como está o estado da arte desta linha de pesquisa voltada para o ensino de Ciências e Física. Essa retomada visa a dar sustentação à nossa construção de categorias. Por isso, devemos levar conosco, sempre em mente, as nossas perguntas de pesquisa:

Quais os tipos de perguntas feitas pelo professor em uma aula de Física em que os alunos resolvem um problema? Que tipo de contribuição as perguntas podem trazer para um ensino que vise à $A C ?$

Olhando para nossas perguntas de pesquisa, devemos buscar meios para que possamos nos aproximar de respostas satisfatórias para elas. Parece-nos clara a necessidade de elaborar uma categorização para verificar quais os tipos de perguntas, e esta advém dos muitos trabalhos que focam seu olhar nas interações discursivas e daqueles que nos ancoram enquanto estrutura teórica. Muitos trabalhos têm olhado as interações discursivas em Ciências respaldados pelos mesmos referenciais aos quais nos filiamos. Os frutos dessas pesquisas nos são profícuos, pois abrangem a perspectiva discursiva e o Ensino de Ciências com sua epistemologia diferente das outras áreas do conhecimento. Devemos, portanto, olhá-los para estruturar nossas categorias e diferenciar nosso entendimento de pergunta dos objetos da linguagem de natureza semelhante que aparecem nas investigações sobre interações discursivas.

No capítulo 3 do Handbook of Research on Science Education, de 2007, intitulado Linguagem e Aprendizado Científico, o pesquisador Willian Carlsen faz um histórico da pesquisa em ensino de Ciências na perspectiva da linguagem. Esse trabalho nos dá uma dimensão ampla do que vem sendo estudado na área e como a pergunta, da forma como a entendemos, pode aparecer nesses estudos. Carlsen resgata Vygotsky, na medida em 
que este entende o conhecimento científico como um processo, passando de uma linguagem abstrata para uma concreta. Ao trazer o pesquisador Jay Lemke (1998), grande expoente da pesquisa em linguagem e em Ciências, Carsen destaca o papel dos diferentes tipos de linguagens existentes no ensino de Ciências, tais como gráficos, diagramas e tabelas, e afirma, de acordo com Lemke, que a aprendizagem em Ciências engloba o domínio e a diferenciação dessas diversas linguagens, que são fundamentais para o aprendizado em Ciências.

Para Lemke, os sistemas semióticos característicos das Ciências constituem também uma linguagem, e os objetos desta carregam uma noção de significação na qual esses objetos ganham forma no compartilhamento e na interação sociohistoricamente situados. O mesmo sentido fora apontado anteriormente em Bakhtin. "Cada palavra é rica de significados", argumenta Lemke:

\begin{abstract}
"significados que se acumulam à medida que os encontramos em muitos contextos diferentes. Cada palavra é uma intersecção de muitas declarações, muitos discursos que fazem uso dela. Cada palavra (num contexto) faz parte de alguma possível troca de significados entre os diferentes membros de uma comunidade (cf. LEMKE, 1998b). E o que é verdade para as palavras não é menos verdade para fotos e diagramas, gráficos e mapas, equações e representações simbólicas, e para o simbolismo das ações que significam tanto quanto acontecem." (CARLSEN, 1998, p. 08, tradução nossa)
\end{abstract}

E ainda de acordo com ele:

"O objetivo da educação científica deveria ser o de capacitar os alunos para a utilização de todas as linguagens da Ciência de formas significativas e apropriadas, e, acima de tudo, poder integrá-las funcionalmente na condução da atividade científica." (CARLSEN, 1998, p. 08, tradução nossa)

É interessante notar o papel das diversas linguagens que compõem a Ciência e que a dimensão discursiva se prolonga não só na oralidade enunciativa, mas também nas diversas formas de expressão. Os discursos se constituem também nas distintas formas de interagir, de usar símbolos, ferramentas e objetos. Em sala de aula, o professor dispõe desses elementos para dialogar com os educandos, e a pergunta coloca no centro do diálogo uma direção à forma de interação dos significados e instrumentos em jogo. 
Ainda no extenso trabalho de Carlsen, um dos quatro grandes levantamentos feito por ele diz respeito às linhas de pesquisa voltadas à questão: o que um orador parece estar fazendo? Essa questão remete ao professor enquanto orador em uma situação didática. Carlsen aponta duas principais vertentes mais estudadas durante 0 levantamento: o orador controla o discurso e o orador cria oportunidade para que haja construção de sentido. A pergunta do professor permeia as duas vertentes, pois, como já lembramos, ela é um instrumento e depende dos propósitos do professor. Resume Carlsen:

\begin{abstract}
"Perguntas docentes refletem tanto a autoridade do professor como a reforçam (Carlsen, 1991a). Perguntas afirmam o poder sociolinguístico (Mischler, 1978) e quando professores se encontram na discussão de um assunto que não lhes é familiar, eles podem confiar nas perguntas para se servirem de tópicos de discussão que lhes deixarão em território desconfortável (Carlsen, 1991b). Isto cria o que Driver (1983) chama de dilema do professor de Ciências: ensinar ciências como um processo de arguição ou como um corpo de conhecimento onde pousa um desafio linguístico constante?" (CARLSEN, p. 07, 2007, tradução nossa)
\end{abstract}

Estamos de acordo com essa colocação na medida em que reconhecemos a autoridade do professor como aquela repousada no saber a ser ensinado. Ressaltamos, entretanto, a distinção entre a autoridade à qual nos referimos e o autoritarismo emergente do discurso uníssono do professor. Defendemos o território desconfortável da dúvida e entendemos nosso objeto "pergunta" como a ponte para esse território. $\mathrm{Na}$ resolução do dilema proposto por Driver e apontado por Carlsen, estamos, com esta pesquisa, defendendo que o ensino da Física é um corpo de conhecimento e nosso trabalho se localiza como parte do "desafio linguístico constante", como Carlsen expôs acima.

Reconhecemos, ademais, que no momento em que o professor cria oportunidades para a construção de sentido, ele está de posse da fala, mas esse controle se distingue ontologicamente do controle do discurso pelo seu propósito. Controlar o discurso pode ser uma ferramenta, constituída de perguntas, para enfatizar o autoritarismo do professor e o estigma do mestre. Por outro lado, criar oportunidades para construção de sentido, é, sim, utilizar-se de uma ferramenta constituída de perguntas para possibilitar avanços, explorar, simbolizar, contribuir para solução de um problema compartilhado, democratizar a relação de construção do conhecimento, promover significação de conceitos e um espírito 
questionador.

Essa estrutura de controle do discurso é forte e universal em sala de aula. Em um trabalho de grande repercussão para os estudos sobre interações discursivas, Mehan, em 1979, mostrou, a partir da análise dos discursos em sala de aula, que há um padrão discursivo triádico corrente denominado IRA (Iniciação - Resposta - Avaliação). De acordo com esse padrão, o professor faz uma iniciação (elicitação) aos alunos e avalia a resposta do aluno. Em outras variações não triádicas, o professor pode dar um feedback (F) ou um prosseguimento (P) na interação em curso. Para Mehan, a aula pode ser dividida em etapas: abertura, desenvolvimento e fechamento, e cada etapa apresenta, de acordo com suas exaustivas análises, um padrão discursivo característico.

Mehan classificou ainda os diferentes tipos de iniciação/elicitação e as respectivas respostas, conforme a tabela 1 :

\begin{tabular}{|l|l|}
\hline Iniciativa & Resposta \\
\hline Elicitação de escolha & Resposta de escolha \\
\hline Elicitação de produto & Resposta de produto \\
\hline Elicitação de processo & Resposta de processo \\
\hline Elicitação de meta-processo & Resposta de reflexão \\
\hline
\end{tabular}

Tabela1: tipos de iniciação (MEHAN, 1979)

No curso da interação, certos atos de respostas são solicitados por certos atos de iniciação; uma elicitação de escolha parece demandar uma resposta de escolha (como a elicitação "você acham que é isso ou aquilo...?"); uma elicitação de processo envolve uma resposta de processo; e assim por diante. Essas relações de coocorrências parecem governar as sequências interacionais com grande regularidade.

Em um artigo detalhado sobre análises discursivas na determinação de perfis conceituais, Mortimer e Amaral (2006) lembram o trabalho de Mehan com a ressalva de que "o início de uma interação não é necessariamente uma pergunta e a resposta representa uma manifestação significativa do aluno ou do professor com relação a uma iniciação". Essa é uma observação importante, pois nosso sentido de pergunta se diferencia de uma iniciação. Uma iniciação pode ser uma afirmação, uma fala qualquer, e abrange uma gama de representações diferentes, como um gesto, um olhar ou uma fala. Enquanto a pergunta, que pode também ser expressa sem uma pontuação de interrogação, carrega consigo o senso de estímulo à cadeia enunciativa, para que haja uma fala externa causada por ela. 
É interessante notar a presença dos papéis de avaliador e gerenciador do discurso nas pesquisas que estamos apresentando. Outro trabalho importante para a composição do corpus para elaborar nossas categorias é o de Rodrigo Drummond Vieira e Silvânia Nascimento, no qual se discute e analisa o conceito de Procedimentos Discursivos Didáticos (PDD). Os PDD são intervenções discursivas de repercussão concreta em sala de aula. Um resumo se encontra na tabela 2.

A base para a construção desses procedimentos localiza-se no padrão argumentativo de Toulmin (2006), vastamente utilizado nas pesquisas em argumentação e ensino de Ciências no mundo. A dimensão argumentativa está fortemente presente em nosso olhar na medida em que permite entender como os educandos constroem hipóteses de solução, os dados em discussão e as justificativas de modo a argumentar ativamente na busca pela construção de um conceito quando estão diante de um problema. E é nesse bojo argumentativo que os PDDs emergem como intervenções do professor.

\begin{tabular}{|c|c|c|}
\hline Papéis do formador & $\begin{array}{ll}\begin{array}{l}\text { Procedimentos } \\
\text { Didáticos }\end{array} & \text { Discursivos } \\
\end{array}$ & Descrição do procedimento \\
\hline $\begin{array}{l}\text { Avaliador de pontos } \\
\text { de vista }\end{array}$ & $\begin{array}{l}\text { Justificação de um ponto de vista } \\
\text { Confirmação de ponto de vista } \\
\text { Reelaboração de um ponto de vista }\end{array}$ & $\begin{array}{l}\text { Formador imagina possíveis justificativas e evidências } \\
\text { que podem dar suporte a uma opinião } \\
\text { Formador assegura um ponto de vista ou justificativa } \\
\text { de um licenciando } \\
\text { Formador retoma um dado ponto de vista alheio e o } \\
\text { reelabora em sua fala }\end{array}$ \\
\hline $\begin{array}{l}\text { Gerenciador } \\
\text { discussão }\end{array}$ & $\begin{array}{l}\text { Explicitação de um ponto de vista } \\
\text { Sumarização de ideias discutidas } \\
\text { Enunciação de pontos de vista } \\
\text { contraditórios } \\
\text { Elaboração de feedbacks eliciativos } \\
\text { Interrupção de turnos de fala dos } \\
\text { licenciandos } \\
\text { Estabelecimento da última palavra }\end{array}$ & $\begin{array}{l}\text { Formador expõe o seu próprio ponto de vista } \\
\text { Formador sintetiza, em sua fala, ideias, pontos de } \\
\text { vista e justificativas anteriores sobre uma dada } \\
\text { questão } \\
\text { Formador enuncia dois pontos de vista contraditórios } \\
\text { sobre uma mesma questão } \\
\text { Formador solicita um ponto de vista sobre uma dada } \\
\text { questão ou pede por maior elaboração na fala de um } \\
\text { licenciando } \\
\text { Formador interrompe a fala de um licenciando para } \\
\text { avaliar o que foi dito ou dar sua opinião sobre o } \\
\text { assunto em pauta } \\
\text { Formador finaliza a discussão com enunciações que } \\
\text { redirecionam a atenção da turma para outra } \\
\text { discussão ou atividade }\end{array}$ \\
\hline Auscultador & Escuta atenta & $\begin{array}{l}\text { Formador se mantém em silêncio prestando atenção } \\
\text { nas trocas discursivas entre os licenciandos }\end{array}$ \\
\hline
\end{tabular}

Tabela 2: os procedimentos discursivos didáticos (DRUMMOND e NASCIMENTO, 2009, p. 448) 
Esse trabalho nos é importante por dois motivos: primeiro, pela aproximação argumentativa com a perspectiva investigativa que queremos assegurar no modo como alunos e professores atuam em uma atividade problematizadora; segundo, pelos PDDs como modos de intervenção, que não contemplam as perguntas. Em nosso entendimento, as perguntas são objetos essenciais para que tanto os PDDs quanto as argumentações ocorram. Incluir a pergunta nesta dimensão é enriquecer o espectro dos procedimentos adotados pelos professores e situar suas funções. Notemos, além disso, a presença dos papéis de avaliador e gerenciador do discurso, mais uma vez dispostos na forma como educadores lidam com as discussões e argumentações em sala de aula, de acordo com o trabalho de Vieira e Nascimento (2009).

\subsection{A construção de um instrumento de análise das perguntas em aulas} problematizadoras de física

"O que nos impressiona são as diferentes formas pelas quais os professores interagem com seus estudantes ao falar sobre os conteúdos científicos: em algumas salas, as palavras estão por toda a parte. Os professores fazem perguntas que levam os estudantes a pensar e os estudantes são capazes de articular suas ideias em palavras, apresentando pontos de vista diferentes. Em algumas ocasiões o professor lidera as discussões com toda a classe. Em outras, os estudantes trabalham em pequenos grupos e o professor desloca-se continuamente entre os grupos, ajudando os estudantes a progredirem nas tarefas. Em outras salas de aula, o professor faz uma série de questões e as respostas dos estudantes, na maioria das vezes, limitam-se a palavras aqui e acolá, preenchendo as lacunas no discurso do professor. Muitas vezes o professor é extremamente hábil nesse estilo de exposição, mas há muito pouco espaço para os estudantes fazerem e falarem algo, e muitos nunca abrem a boca."

Mortimer e Scott (2002)

Nossa construção de categorias abrange três vertentes principais:

1) $O$ princípio de ensino investigativo em Física, presente na noção de ciclo 
argumentativo, no qual os alunos lançam mão de estratégias discursivas para argumentar diante de um problema de investigação;

2) O conceito de propósito, imprescindível para a ação consciente de perguntar. Essa vertente está presente nas intenções discursivas analisadas por Mortimer e Scott (2000);

3) As classificações de perguntas existentes para o ensino de Ciências cujos enfoques são distintos, mas compõem um espectro dos tipos e categorias disponíveis para olharmos a pergunta do professor em aulas investigativas de Física.

O ciclo argumentativo, proposto por Sasseron e Carvalho (2011), surgiu em decorrência de uma pesquisa visando a entender como os alunos constroem os argumentos em sala de aula. Em uma SEI aplicada em turmas do ensino fundamental, as autoras buscaram verificar quais elementos discursivos apareciam na construção de argumentos orais para o problema apresentado. No trabalho, elas defendem a argumentação como "a capacidade de relacionar dados e conclusões, de avaliar enunciados teóricos à luz dos dados empíricos ou procedentes de outras fontes" (SASSERON, 2011, p. 06).

Com base nos estudos sobre argumentação, as autoras usaram os indicadores de alfabetização científica (SASSERON, 2008) para analisar a construção dos argumentos nessas aulas. Estes indicadores representam habilidades discursivas e ações articuladas pelos alunos para resolver o problema.

\begin{tabular}{|l|l|}
\hline \multicolumn{1}{|c|}{$\begin{array}{l}\text { Indicadores de alfabetização } \\
\text { científica }\end{array}$} & \multicolumn{1}{c|}{ Funcionalidade } \\
\hline $\begin{array}{l}\text { Levantamento de hipótese } \\
\text { Teste de hipótese }\end{array}$ & $\begin{array}{l}\text { Indicadores relacionados com a obtenção de dados e delimitação de } \\
\text { variáveis. }\end{array}$ \\
\hline $\begin{array}{l}\text { Classificação de informações } \\
\text { Seriação de informações } \\
\text { Organização de informações }\end{array}$ & Indicadores relacionados ao trabalho com os dados empíricos. \\
\hline $\begin{array}{l}\text { Explicação } \\
\text { Justificativas } \\
\text { Previsão }\end{array}$ & Indicadores de relação entre variáveis e informações. \\
\hline $\begin{array}{l}\text { Raciocínio lógico } \\
\text { Raciocínio proporcional }\end{array}$ & \\
\hline
\end{tabular}

Tabela 3: os indicadores de Alfabetização Científica e suas funcionalidades

Ao aplicar os indicadores para momentos diferentes das aulas investigativas, as autoras observaram a presença de um ciclo argumentativo, como chamaram, no qual os argumentos se desencadeiam durante a investigação dialogando com as informações disponíveis e a forma como eles se constroem de acordo com o desenvolvimento da 
atividade. Esse ciclo, nas aulas investigativas, aparecia claramente com indicadores relacionados: 1) aos dados no início da investigação; 2) à definição de variáveis, momento em que os alunos apresentam indicadores de elaboração e teste de hipóteses, assim como previsões e justificativas; 3) aos indicadores de apropriação de ideias em caráter científico, que são mais observados nos momentos finais das investigações, após o processo de discussão. Em suma, o ciclo apresenta três movimentos relacionados, respectivamente, com os dados, o processo de investigação e as apropriações.

Notemos, em tempo, que esse ciclo não é hermético, foi observado nas aulas investigativas da sequência proposta. Notemos, ademais, que a aproximação entre a argumentação dos alunos e o ensino investigativo de Ciências é parte da demanda trazida pelo problema, pois, posto um problema de investigação, as hipóteses, os dados e as refutações/validações/justificativas são parte de um processo de argumentação. É parte da investigação em curso nas atividades problematizadoras descartar variáveis, elaborar hipóteses, justificativas e explicações. Esses indicadores se relacionam com o ensino investigativo de forma ontológica no seio da episteme contida na investigação.

Defendemos, todavia, a utilização do conceito de ciclo argumentativo na construção nas nossas categorias: primeiro pela sua relação com o ensino investigativo e a forma como visualizamos o desenvolvimento de uma aula ou SEI; segundo, pela percepção de que há, para cada momento do ciclo, um comportamento discursivo diferente do professor. Esse comportamento também faz parte do nosso corpus de elaboração das categorias, consistindo de um segundo trabalho a ser considerado: o de Mortimer e Scott (2002).

Mortimer trabalhou com James Wertsch em seu pós-doutoramento nos Estados Unidos. Ele carrega em seus trabalhos, assim como Scott, os referenciais bakthiniano, vigostikiano e wertschiano. No trabalho publicado em conjunto, Mortimer e Scott elaboraram uma metodologia de análise do discurso para entender como ocorrem as interações professor-aluno em sala de aula e, sobretudo, a produção de significado. Os autores utilizam o conceito de gênero do discurso, elaborado pelo Círculo de Bakhtin e que é "constituído de tipos estáveis de enunciados no qual cada esfera da linguagem é usada" (BAKHTIN, 2009). Em uma construção detalhada e aplicada para uma investigação sobre oxidação em aula de química, os autores buscam abranger as diferentes esferas da linguagem utilizadas pelo professor de modo a se aproximar ao máximo de uma descrição precisa dos movimentos discursivos em aula. A estrutura analítica dos discursos abrange 0 papel do professor no que tange a cinco aspectos interrelacionados e dispostos em três 
blocos: os focos do ensino, a abordagem comunicativa do professor e as ações discursivas do professor.

l) Os focos do ensino relacionam-se com as intenções do professor, ou seja, qual o problema proposto, como ele foi pensado, de que forma o professor utilizará as concepções prévias dos alunos, como ele pretende guiar a atividade. As intenções estão diretamente relacionadas ao conceito de propósito de Wertsch. Uma alusão ao propósito é importante na definição da ação expressa por Wertsch, pois coloca, em uma ação discursiva, a intenção contida nela. Os autores definiram quais os tipos de intenções aparecem em sala de aula durante a investigação. São seis e estão organizados abaixo:

\begin{tabular}{|l|l|}
\hline \multicolumn{1}{|c|}{ Intenções do professor } & \multicolumn{1}{c|}{ Foco } \\
\hline Criando um problema. & $\begin{array}{l}\text { Engajar os estudantes, intelectual e emocionalmente, no } \\
\text { desenvolvimento inicial da 'história científica'. }\end{array}$ \\
\hline Explorando a visão dos estudantes. & $\begin{array}{l}\text { Elicitar e explorar as visões e entendimentos dos estudantes } \\
\text { sobre ideias e fenômenos específicos. }\end{array}$ \\
\hline $\begin{array}{l}\text { Introduzindo e desenvolvendo a 'história } \\
\text { científica'. }\end{array}$ & $\begin{array}{l}\text { Disponibilizar as ideias científicas (incluindo temas conceituais, } \\
\text { epistemológicos, tecnológicos e ambientais) no plano social da } \\
\text { sala de aula. }\end{array}$ \\
\hline $\begin{array}{l}\text { Guiando os estudantes no trabalho com as } \\
\text { ideias científicas, e dando suporte ao processo } \\
\text { de internalização. }\end{array}$ & $\begin{array}{l}\text { Dar oportunidades aos estudantes de falar e pensar com as } \\
\text { novas ideias científicas, em pequenos grupos e por meio de } \\
\text { atividades com a toda a classe. Ao mesmo tempo, dar suporte } \\
\text { aos estudantes para produzirem significados individuais, } \\
\text { internalizando essas ideias. }\end{array}$ \\
\hline $\begin{array}{l}\text { Guiando os estudantes na aplicação das ideias } \\
\text { científicas e na expansão de seu uso, } \\
\text { transferindo progressivamente para eles o } \\
\text { controle e responsabilidade por esse uso. }\end{array}$ & $\begin{array}{l}\text { Dar suporte aos estudantes para aplicar as ideias científicas } \\
\text { ensinadas a uma variedade de contextos e transferir aos } \\
\text { estudantes controle e responsabilidade (Wood et al., 1976) pelo } \\
\text { uso dessas ideias. }\end{array}$ \\
\hline $\begin{array}{l}\text { Mantendo a narrativa: sustentando o } \\
\text { desenvolvimento da 'história científica'. }\end{array}$ & $\begin{array}{l}\text { Prover comentários sobre o desenrolar da 'história científica', de } \\
\text { modo a ajudar os estudantes a seguir seu desenvolvimento e a } \\
\text { entender suas relações com o currículo de Ciências como um } \\
\text { todo. }\end{array}$ \\
\hline
\end{tabular}

Tabela 4: as intenções do professor para Mortimer e Scott (2002)

Outra perspectiva do foco de ensino é o conteúdo do discurso em sala de aula. Este pode referir-se aos tipos de interações desenvolvidas entre professor e aluno, podendo ser relacionadas à atividade, aos aspectos procedimentais e ao gerenciamento e manejo da sala. No trabalho, os autores desconsideram os conteúdos procedimentais e de manejo da turma, focando a análise nos conteúdos dos discursos na atividade. Neste aspecto, os autores classificam a interação como explicação, descrição ou generalização.

II) A abordagem comunicativa do professor fornece informações para a análise sobre como o professor trabalha as intenções e o conteúdo do ensino por meio das 
diferentes intervenções pedagógicas que resultam em diferentes padrões de interação.

As formas de abordagem podem ser basicamente: dialógica em que se contrapõem posições e vozes diferentes acerca do conteúdo; de autoridade, que apresenta uma visão única; interativa, na qual os alunos e o professor interagem na discussão; e não interativa, em que o professor sozinho discursa. Essas classes de abordagem relacionam-se diretamente com o papel do professor nos momentos em que ele controla o discurso em sala de aula. Elas aparecem em pares, podendo ser: dialógica-interativa, na qual o professor contrapõe pontos de vista chamando os alunos a contribuírem e interagindo com eles; dialógica-não interativa, na qual o professor não interage com os alunos, mas contrapõe visões acerca de um conhecimento utilizando ou não as ideias dos alunos; interativo-de autoridade, no qual o professor interage com os alunos, mas apresenta uma visão única acerca de um fenômeno e, via de regra, impõe essa visão aos estudantes; e não interativa-de autoridade, na qual só o professor fala, expondo uma visão única do fenômeno.

III) as ações do professor referem-se ao desenvolvimento da aula e aos movimentos discursivos implicados das interações, sejam os padrões discursivos estabelecidos ou as intervenções realizadas pelo professor. Foram chamados de padrão discursivo (IRA), no qual o professor elabora uma iniciação (I), os alunos dão uma resposta (R) e o professor, uma avaliação (A). Tais padrões foram elaborados primeiramente por Mehan (1979) e podem continuar com um feedback ou prosseguimento. Por último, as interações também são influenciadas pelas intervenções do professor diante de uma pergunta ou uma colocação. Essas intervenções podem dar forma aos significados, selecioná-los, marcá-los, compartilhá-los, verificar a compreensão dos alunos sobre eles e rever os procedimentos.

Dessa descrição das formas de interação entre professor e alunos (Mortimer e Scott, 2002), destacamos a distinção entre a pergunta, como a entendemos neste trabalho, e a iniciação do padrão de interação de Mehan (1979). Não consideraremos o conceito de iniciação para a construção de nossas categorias, pois não se trata de uma pergunta. O mesmo faremos com a "abordagem do professor" e "o conteúdo do discurso", pois a pergunta pode estar em todas essas vertentes, e como desejamos estudar a pergunta, sua relação com as abordagens comunicativas só pode ser construída a posteriori. Por outro lado, destacamos em nosso referencial teórico a importância do propósito didático para a pergunta, que está presente no trabalho de Mortimer e Scott como intenções discursivas do professor. É importante, para nós, ter, como pano de 
fundo, a noção de que a pergunta deve necessitar de um propósito. Assim, da ferramenta analítica proposta por Mortimer e Scott (2002), utilizaremos as intenções do professor como base para a construção das nossas categorias.

Postos os dois referenciais teóricos para justificar a categorização das perguntas do professor em aulas investigativas de Ciências, devemos ressaltar uma diferença entre eles. O primeiro, do ciclo argumentativo, apresenta diferentes momentos de argumentação dos alunos no desenvolvimento de uma aula investigativa, portanto, o foco do trabalho são os alunos; o segundo analisa primordialmente o professor. Mas ambos se preocupam com as interações discursivas em aulas investigativas. Assumindo que a aula investigativa apresenta diferentes momentos - como foi verificado no ciclo argumentativo , devemos primar que, para cada momento, haja intenções diferenciadas para o professor, de modo a garantir que os alunos tenham conhecido os dados, verificado as variáveis, elaborado e testado justificativas, e assim por diante. Apresentamos na tabela 5 como essas duas teorias se relacionam ao nosso ver.

\begin{tabular}{|l|l|}
\hline \multicolumn{1}{|c|}{ Intenções do professor (Mortimer e Scott) } & \multicolumn{1}{|c|}{ Aspectos do Ciclo argumentativo } \\
\hline$\bullet \quad \begin{array}{l}\text { Criando um problema. } \\
\text { Explorando a visão dos estudantes. }\end{array}$ & $\begin{array}{l}\text { Indicadores relacionados com a obtenção de } \\
\text { dados e delimitação de variáveis. Indicadores } \\
\text { relacionados ao trabalho com os dados } \\
\text { empíricos. }\end{array}$ \\
\hline - $\quad$ Introduzindo e desenvolvendo a 'história científica'. & $\begin{array}{l}\text { Indicadores de relação entre variáveis e } \\
\text { informações }\end{array}$ \\
\hline - $\quad \begin{array}{l}\text { Guiando os estudantes no trabalho com as ideias científicas e } \\
\text { dando suporte ao processo de internalização. } \\
\text { na expansão de seu uso, transferindo progressivamente para } \\
\text { eles o controle e responsabilidade por esse uso. }\end{array}$ & $\begin{array}{l}\text { Indicadores de apropriação de ideias em caráter } \\
\text { científico. }\end{array}$ \\
\hline $\begin{array}{l}\text { Mantendo a narrativa: sustentando o desenvolvimento da } \\
\text { 'história científica'. }\end{array}$ & \\
\hline
\end{tabular}

Tabela 5: as intenções do professor e as etapas do ciclo argumentativo em aulas investigativas.

Observemos desse comparativo - e com certa naturalidade - a ausência das perspectivas de criação do problema, de experiências prévias dos alunos e de sustentação da "história científica". A etapa de criar o problema é essencial para uma aula investigativa, pois, se o problema não for bem compreendido, as etapas do ciclo se diluem. Verificar o conhecimento prévio do aluno é também uma parte da criação do problema, pois, sem este conhecimento prévio, não se reconhece o problema proposto, e o aluno precisa reconhecer o problema e tê-lo para si de modo a se engajar na sua resolução. Para haver o ciclo é necessário um problema. E tomaremos a esfera discursiva 
da intenção de criar um problema como parte importante para construir nossas categorias. Essa intenção se reflete nas intervenções do professor, de acordo com Mortimer e Scott (2002), e, sendo assim, podem apresentar como respostas todos os indicadores.

Dessa comparação, incorporando a criação do problema às três funcionalidades discursivas do ciclo argumentativo, observamos os tipos de intenção do professor na ação discursiva e consideraremos essa intenção importante para a expressão enunciativa dos alunos ao responder. Assim, a pergunta mantém-se como instrumento dialógico de estímulo à cadeia enunciativa e contém em si intenções discursivas oriundas do propósito didático.

Como desdobramento, tomaremos como noções relevantes para olhar a pergunta do professor o que, a partir de agora, chamaremos de "Aspectos Discursivos do Ensino Investigativo", e são quatro: 1) A criação do problema, 2) 0 trabalho com os dados, 3) o processo de investigação, e 4) A explicação ou internalização dos conceitos. Ao relacionar as categorias para as intenções do professor com as etapas do ciclo argumentativo dos alunos, vemos que elas apresentam uma relação estreita entre o que o professor pergunta e a resposta dos alunos. Essas quatro esferas de uma aula investigativa devem refletir-se no comportamento discursivo do professor, por isso as tomaremos como base de construção das categorias e relacionaremos a seguir essas esferas com os trabalhos nas áreas de Ciências cujos frutos fornecerão classificações de perguntas do professor. Essa relação visa a aproximar as classificações já existentes dos nossos propósitos de análise para ensino investigativo e a fortalecer nossas categorias nas quatro esferas propostas.

3.2.1 As categorias existentes, os aspectos discursivos do ensino investigativo e a elaboração de uma nova categorização.

Em revisão da literatura encontramos três classificações diferentes relacionadas aos tipos de pergunta em sala de aula de Ciências (PENICK, 2007; MARTENS, 1999; e HARLEN, 1996). Cada uma delas buscou analisar as perguntas de acordo com uma perspectiva diferente. O que faremos é relacionar essas categorias com a nossa perspectiva de ensino investigativo presente nas quatro esferas de interações discursivas levantadas por nós. O trabalho de Martens (1999) organiza as perguntas possíveis dos professores em seis categorias, que vão desde a chamada de atenção para os detalhes 
de um problema e o cuidado com as informações existentes, passando pela análise e classificação das mesmas, culminando em questões que façam os alunos proporem explicações e construírem ideias e modelos sobre o caso estudado. A autora foca seu estudo em crianças entre 7 e 10 anos do ensino fundamental americano e no desenvolvimento de habilidades científicas dos alunos de modo a incentivá-los a observar os objetos de estudo e construir coletivamente conceitos científicos. A classificação proposta por ela está exposta na tabela 6 conforme nossa tradução:

\begin{tabular}{|l|l|l|}
\hline \multicolumn{1}{|c|}{ Tipos de Perguntas } & \multicolumn{1}{|c|}{ Descrição } & \multicolumn{1}{|c|}{ Exemplos } \\
\hline Perguntas de foco e atenção & $\begin{array}{l}\text { Ajudam os alunos a manter o foco e a atenção } \\
\text { nos detalhes. }\end{array}$ & $\begin{array}{l}\text { O que você observa aqui? } \\
\text { O que eles estão fazendo? }\end{array}$ \\
\hline $\begin{array}{l}\text { Perguntas de medição e } \\
\text { contagem }\end{array}$ & Ajudam os alunos a precisar as observações. & $\begin{array}{l}\text { Quantas vezes isso...? } \\
\text { Em quanto tempo....? }\end{array}$ \\
\hline Perguntas de comparação & Ajudam os alunos a analisar e classificar. & $\begin{array}{l}\text { Este é igual ou diferente? } \\
\text { Como atuam juntos....? }\end{array}$ \\
\hline Perguntas de ação & $\begin{array}{l}\text { Ajudam os alunos a explorar as propriedades de } \\
\text { materiais, eventos. A fazer previsões sobre } \\
\text { fenômenos. }\end{array}$ & $\begin{array}{l}\text { O que acontece se...? } \\
\text { O que aconteceria...? }\end{array}$ \\
\hline Perguntas problematizadoras & Ajudam os alunos a planejar e buscar soluções. & $\begin{array}{l}\text { Você pode descobrir como? } \\
\text { Encontre uma maneira....? }\end{array}$ \\
\hline Perguntas de raciocínio & $\begin{array}{l}\text { Ajudam os alunos a pensar sobre a experiência } \\
\text { e construir ideias que façam sentido. }\end{array}$ & $\begin{array}{l}\text { Por que você acha...? } \\
\text { Qual sua razão para...? }\end{array}$ \\
\hline
\end{tabular}

Tabela 6: classificação das perguntas para Mary Lee Martens

O segundo trabalho a analisar as perguntas é de natureza empírica. Em 2006, os pesquisadores do Exploratorium Institute for Inquiry, da Universidade de San Francisco, EUA, elaboraram uma classificação de perguntas em sala de aula: um grupo de professores de Ciências era colocado diante de vídeos com situações de sala de aula de nível médio e, em dados momentos, eles eram indagados sobre qual pergunta fariam aos alunos naquela situação. As categorias resultantes foram: perguntas diretivas em relação à explicação de um fenômeno; perguntas relacionadas aos procedimentos executados em uma investigação; perguntas que levam os questionados a expor hipóteses sobre o problema estudado; e outros tipos de perguntas.

\begin{tabular}{|l|l|l|}
\hline \multicolumn{1}{|c|}{ Tipos de Perguntas } & \multicolumn{1}{|c|}{ Descrição } & \multicolumn{1}{|c|}{ Exemplo } \\
\hline Perguntas centradas no assunto & $\begin{array}{l}\text { Remetem diretamente ao assunto a } \\
\text { ser estudado; têm somente uma } \\
\text { resposta certa. }\end{array}$ & $\begin{array}{l}\text { Quantas imagens temos nos } \\
\text { espelhos? }\end{array}$ \\
\hline Perguntas centradas no processo & $\begin{array}{l}\text { Buscam selecionar e destacar } \\
\text { variáveis; envolvem o processo de } \\
\text { investigação. }\end{array}$ & $\begin{array}{l}\text { De que forma ficou isso quando você } \\
\text { aumentou aquilo? }\end{array}$ \\
\hline Perguntas centradas na pessoa & $\begin{array}{l}\text { Não existem respostas certas ou } \\
\text { erradas; buscam extrair o que os }\end{array}$ & O que você acha que explica...? \\
\hline
\end{tabular}




\begin{tabular}{|l|l|ll|}
\hline & alunos acham ou sabem. & & \\
\hline Outros tipos de perguntas & $\begin{array}{l}\text { Perguntas que não se enquadram no } \\
\text { perfil anterior. }\end{array}$ & $\begin{array}{l}\text { O que você sabe sobre a } \\
\text { propriedade....? }\end{array}$ \\
\hline
\end{tabular}

Tabela 7: organização da classificação do Institute for inquiry para os tipos de perguntas.

O terceiro trabalho é o estudo de Penick (apud CLOUGH, 2007). Voltado para o trabalho experimental em aulas de Ciências, o autor sugere cinco categorias hierárquicas para classificar as perguntas feitas pelo professor. Sua classificação se volta à pergunta como contendo um significado próprio e, a partir daí, atribui sentido a ela. As categorias propostas partem desde: perguntas que levam os alunos a apresentarem suas observações do processo vivenciado; perguntas que permitem a comparação entre diferentes dados, informações e ideias; perguntas que remetem à aplicação do conhecimento estudado para outras situações; perguntas que exigem o levantamento de hipóteses sobre o conceito quando visto em outros contextos; e perguntas que se relacionam mais especificamente às relações causais. $\mathrm{Na}$ tabela 8 , resumimos a classificação de Penick.

\begin{tabular}{|l|l|l|}
\hline \multicolumn{1}{|c|}{ Tipos de Perguntas } & \multicolumn{1}{|c|}{ Descrição } & \multicolumn{1}{c|}{ Exemplo } \\
\hline Perguntas de História & Dizem respeito à experiência em curso. & $\begin{array}{l}\text { O que você fez...? } \\
\text { O que acontece quando você....? }\end{array}$ \\
\hline Perguntas de relacionamento & $\begin{array}{l}\text { Envolvem os alunos na comparação de } \\
\text { ideias. }\end{array}$ & $\begin{array}{l}\text { Como isso se compara a...? } \\
\text { O que estes têm em comum? }\end{array}$ \\
\hline Perguntas de aplicação & $\begin{array}{l}\text { Requerem que o estudante use o o } \\
\text { conhecimento em outro contexto. }\end{array}$ & $\begin{array}{l}\text { Como isso poderia ser usado para...? } \\
\text { Conhece algum outro lugar onde isso } \\
\text { acontece? }\end{array}$ \\
\hline Perguntas de especulação & $\begin{array}{l}\text { Requerem raciocínio para além do } \\
\text { experimento. }\end{array}$ & $\begin{array}{l}\text { O que aconteceria se...? } \\
\text { Quais problemas podem resultar se...? }\end{array}$ \\
\hline Perguntas de explanação & $\begin{array}{l}\text { Buscam razões subjacentes à à } \\
\text { investigação. Raciocínio. }\end{array}$ & $\begin{array}{l}\text { Como isso funciona? } \\
\text { Como podemos explicar isso? }\end{array}$ \\
\hline
\end{tabular}

Tabela 8: classificação das perguntas segundo Penick (1986)

Os trabalhos estudados e mencionados anteriormente esboçam e explicitam ideias quanto às perguntas dos professores em aulas de Ciências. No entanto, como enfatizamos, cada uma destas pesquisas foi realizada em situações distintas cujas razões nem sempre estavam ligadas às interações discursivas no âmbito de uma atividade investigativa, ocorridas em sala de aula. Considerando nossos objetivos, comparamos na tabela a seguir como tais categorias se enquadram em relação as quatro aspectos discursivos para o ensino investigativo, levantados no item 3.2 deste trabalho. Nossa intenção com a comparação é localizar dentro do propósito e do contexto de elaboração 
da classificação o que já existia anteriormente sobre perguntas e, assim, fortalecer nossa construção.

\begin{tabular}{|c|c|c|}
\hline $\begin{array}{l}\text { Aspectos discursivos do } \\
\text { ensino investigativo }\end{array}$ & $\begin{array}{l}\text { Ordenação das categorias } \\
\text { existentes dos tipos de } \\
\text { perguntas }\end{array}$ & Descrição \\
\hline \multirow{3}{*}{ Criação do problema } & Perguntas problematizadoras & Ajudam a planejar e buscar soluções. \\
\hline & Perguntas de História & $\begin{array}{l}\text { Dizem respeito à experiência em curso } \\
\text { (prévias e observadas). }\end{array}$ \\
\hline & Perguntas centradas na pessoa & $\begin{array}{l}\text { Buscam extrair o que os alunos acham ou } \\
\text { sabem. }\end{array}$ \\
\hline \multirow[t]{4}{*}{ Trabalho com os dados } & Perguntas de foco e atenção & $\begin{array}{l}\text { Ajudam os alunos a manter o foco e a } \\
\text { atenção nos detalhes. }\end{array}$ \\
\hline & $\begin{array}{l}\text { Perguntas de medição e contagem } \\
\text { Perguntas de comparação }\end{array}$ & $\begin{array}{l}\text { Ajudam os alunos a precisar as } \\
\text { observações. } \\
\text { Ajudam os alunos a analisar e classificar. }\end{array}$ \\
\hline & Perguntas centradas no assunto & $\begin{array}{l}\text { Remetem diretamente ao assunto a ser } \\
\text { estudado. }\end{array}$ \\
\hline & Perguntas de ação & $\begin{array}{l}\text { Ajudam os alunos a explorar as } \\
\text { propriedades de materiais, eventos. }\end{array}$ \\
\hline \multirow{3}{*}{ Processo de investigação } & Perguntas de ação & Ajudam a fazer previsões sobre fenômenos. \\
\hline & Perguntas centradas no processo & $\begin{array}{l}\text { Buscam selecionar e destacar variáveis; } \\
\text { envolvem o processo de investigação. }\end{array}$ \\
\hline & Perguntas de relacionamento & $\begin{array}{l}\text { Envolvem os alunos na comparação de } \\
\text { ideias. }\end{array}$ \\
\hline \multirow{6}{*}{$\begin{array}{l}\text { Apropriação ou Internalização } \\
\text { dos Conceitos }\end{array}$} & Perguntas de raciocínio & $\begin{array}{l}\text { Ajudam os alunos a pensar sobre a } \\
\text { experiência e construir ideias que façam } \\
\text { sentido. }\end{array}$ \\
\hline & Perguntas centradas na pessoa & $\begin{array}{l}\text { Buscam extrair o que os alunos acham ou } \\
\text { sabem. }\end{array}$ \\
\hline & Perguntas de aplicação & 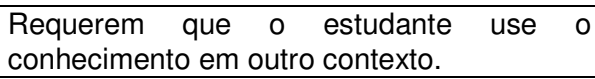 \\
\hline & Perguntas de especulação & $\begin{array}{l}\text { Requerem raciocínio para além do } \\
\text { experimento. }\end{array}$ \\
\hline & Perguntas de explanação & Buscam razões subjacentes à investigação. \\
\hline & Outros tipos de perguntas & Outros tipos de perguntas \\
\hline
\end{tabular}

Tabela 9: aspectos discursivos do ensino investigativo e as classificações vigentes

No aspecto discursivo de "criar o problema", o professor levanta os conhecimentos prévios dos alunos e explicita o problema cuja solução não é trivial aos alunos. As perguntas problematizadoras (MARTEENS, 1999), as de História (PENICK, 2007) e as centradas na pessoa (EXPLORATORIUM INSTITUTE FOR INQUIRY, 2010) se relacionam com a criação do problema na medida em que planejam a ação para problematizar, retiram elementos da atividade para criar o problema e buscam 0 
conhecimento prévio do aluno, respectivamente. Elas aparecem no primeiro item, pois remetem à etapa anterior do processo, em que o problema é criado, contando com o conhecimento prévio do aluno para que este possa observar o problema com auxílio do professor.

Muitas perguntas existentes nas categorias anteriores se relacionam ao trabalho com os dados, pois esta é uma etapa fundamental de uma investigação. Perguntas de foco e atenção, de medição e contagem, e de comparação, como colocadas por Marteens, são essencialmente relacionadas ao trabalho com dados, pois aumentam a acurácia do olhar do aluno para os dados, ajudam a eliminar ruídos nas medidas e comparam-nas. As perguntas centradas no assunto e as perguntas de ação também se relacionam com os dados na medida em que ajudam a explorar as propriedades dos materiais envolvidos. O trabalho com dados envolve comparações de observações, de medidas e de seleção de variáveis.

A pergunta de ação aparece novamente no aspecto discursivo do ensino investigativo como forma de fazer previsões sobre fenômenos. Entendemos que prever e criar hipóteses são etapas distintas da relação com os dados, por isso, essa categoria não pode estar toda em uma parte ou em outra. As perguntas "centradas no processo" e "de relacionamento" também são relativas ao processo de investigação, pois comparam ideias, fazem os alunos explorarem o fenômeno, pensarem sobre ele, criarem e refutarem hipóteses.

As perguntas de especulação e explanação têm o foco central na busca do raciocínio sobre as soluções do problema, na aplicação do conceito em outro contexto, o que pressupõe um entendimento, fazer com que os alunos elaborem explicações. Das categorias existentes, muitas são semelhantes nesse sentido: como as perguntas de raciocínio, pois ajudam os alunos a construir ideias que fazem sentido; as de explanação, pois requerem uma explicação do fenômenos; as de aplicação e de especulação, por buscarem em outro contexto e em outros exemplos a possibilidade de aplicação da solução do problema; e a pergunta centrada na pessoa aparece novamente aqui, na medida em que o processo de internalização é diferente da utilização da experiência prévia do aluno para se criar problema, embora ambos sejam centrados na pessoa.

Por fim, a classificação de pergunta elaborada pelo Institute of Inquiry e intitulada "outros tipos de perguntas" não se encaixa dentro dos aspectos discursivos do ensino investigativo, pois são gerais, buscam abranger o que não está contido em outras categorias. Os únicos exemplos para esse item tratariam de perguntas de gestão do 
ambiente ou da sala. De acordo com nossa definição de pergunta, seriam expressões tais quais: "Você pode mudar de lugar com seu colega?", "Alguém trouxe o experimento?", entre outras, que não se configuram como perguntas.

Ao alocarmos as categorias existentes dentro dos aspectos discursivos do ensino investigativo, algumas delas apresentam caráter ambíguo, encaixando-se em mais de um bloco. É o caso das perguntas de ação remetendo ao trabalho com dados e ao processo, e das perguntas centradas na pessoa que podem explorar o que ela sabe previamente ou o que ela aprendeu após a investigação. Esses exemplos de distinção entre as categorias pré-existentes e os aspectos discursivos do ensino investigativo nos fortalecem em busca de uma classificação mais coesa de acordo com o ensino investigativo. A construção das categorias leva em conta aquelas já existentes reconhecendo, contudo, cada uma delas elaborada com um objetivo distinto das outras. Se buscamos analisar aulas investigativas de Ciências, temos que construir um instrumento analítico que forneça uma descrição mais próxima dos fenômenos discursivos em curso durante as aulas investigativas.

Partindo do reagrupamento proposto por nós, elaboramos nossas categorias de perguntas, considerando os quatro aspectos discursivos do ensino investigativo como vias principais de encaminhamento discursivo para as perguntas nas aulas investigativas. Considerando na construção, em primeiro lugar, o ciclo argumentativo e a sua importância no desenvolvimento dos indicadores de alfabetização científica; em segundo lugar, a importância das intenções discursivas do professor para analisar a pergunta; e, por fim, em terceiro, a incorporação das categorias já existentes de perguntas em aulas de Ciências.

Com base na junção dos referenciais expostos anteriormente, enfatizando os quatro aspectos discursivos do ensino investigativo, propomos que estes são centrais e compõem nossa categorização. Entendemos que as perguntas feitas pelo professor em aulas investigativas planejadas contêm, em si, intenções de exploração da investigação, de relação com as etapas de investigação em curso e com os propósitos didáticos insurgentes do planejamento da aula. Assim, temos quatro categorias principais, todas situadas no curso da investigação. Estas visam a localizar os tipos de perguntas feitas pelo professor nas aulas investigativas. Portanto, na emergência de construção deste instrumento analítico está, conforme insistimos, a intenção do professor nas etapas de uma investigação planejada, de forma a possibilitar olhares e posturas diferentes das apresentadas pelos educandos no processo de construção de conceitos científicos. $\mathrm{Na}$ tabela 10 apresentamos as categorias que consideraremos para analisar aulas de 
Ciências em que se resolve um problema. Este será nosso instrumento analítico para entender melhor as perguntas do professor em sala de aula.

\begin{tabular}{|c|c|c|}
\hline $\begin{array}{c}\text { Classificação das } \\
\text { perguntas }\end{array}$ & Descrição & Exemplos \\
\hline $\begin{array}{l}\text { Perguntas de } \\
\text { problematização }\end{array}$ & $\begin{array}{l}\text { Remetem-se ao problema estudado ou subjacente a ele } \\
\text { dentro da proposta investigativa. Refazem, reformulam de } \\
\text { outra maneira, voltam à proposta do problema. Ajudam os } \\
\text { alunos a planejar e buscar soluções para um problema e } \\
\text { exploram os conhecimentos do aluno antes de eles o } \\
\text { resolverem. Levantam as demandas do problema para que } \\
\text { os alunos iniciem a organização das informações } \\
\text { necessárias para resolvê-lo. }\end{array}$ & $\begin{array}{l}\text { Por que isso acontece? } \\
\text { Como explicar esse fenômeno? }\end{array}$ \\
\hline $\begin{array}{l}\text { Perguntas sobre } \\
\text { dados }\end{array}$ & $\begin{array}{l}\text { Abordam os dados envolvidos no problema. Seja } \\
\text { evidenciando-os, apresentando-os ou selecionando-os de } \\
\text { forma a de descartar ou não variáveis. Direcionam o olhar do } \\
\text { aluno para as variáveis envolvidas relacionando-as, } \\
\text { procurando um grau maior de precisão, comparando ideias, } \\
\text { propondo inversões e mudanças. }\end{array}$ & $\begin{array}{l}\text { O que acontece quando você...? } \\
\text { O que foi importante para que isso } \\
\text { acontecesse? } \\
\text { Como isso se compara a...? }\end{array}$ \\
\hline $\begin{array}{l}\text { Perguntas } \\
\text { exploratórias } \\
\text { sobre o } \\
\text { Processo }\end{array}$ & $\begin{array}{l}\text { Buscam que os alunos emitam suas conclusões sobre os } \\
\text { fenômenos. Podem demandar hipóteses, justificativas, } \\
\text { explicações, conclusões como forma de sistematizar seu } \\
\text { pensamento na emissão de uma enunciação própria. } \\
\text { Buscam concretizar o aprendizado na situação proposta. } \\
\text { Fazem com que o aluno reveja o processo pelo qual ele } \\
\text { resolveu o problema, elucide seus passos. }\end{array}$ & $\begin{array}{l}\text { O que você acha disso? } \\
\text { Como será que isso funciona? } \\
\text { Como chegou a essa conclusão? }\end{array}$ \\
\hline $\begin{array}{l}\text { Perguntas de } \\
\text { sistematização }\end{array}$ & $\begin{array}{l}\text { Buscam que os alunos apliquem o conceito compreendido } \\
\text { em outros contextos, prevejam explicações em situações } \\
\text { diferentes da apresentada pelo problema. Levam o aluno a } \\
\text { raciocinar sobre o assunto e a construir o modelo para } \\
\text { explicar o fenômeno estudado. }\end{array}$ & $\begin{array}{l}\text { Você conhece algum outro } \\
\text { exemplo para isso? } \\
\text { O que disso poderia servir para } \\
\text { este outro....? } \\
\text { Como você explica o fato..? }\end{array}$ \\
\hline
\end{tabular}

Tabela 10: os tipos de perguntas do professor em aulas investigativas de Física

Essas quatro categorias abrangem etapas do processo investigativo importantes para o desenvolvimento da atividade e se constituem ontologicamente pela intenção contida na ação enunciativa de perguntar. A primeira categoria relaciona-se a um momento anterior à investigação, onde se especulam os conhecimentos prévios e se constitui o problema. A categoria de perguntas sobre dados expõe a seleção de dados, eliminação de variáveis, acurácia em medidas ou o melhor conhecimento dos fatores relevantes ao problema. As perguntas sobre processo visam a estimular os alunos a relacionar idéias com dados e observações, criando hipóteses, refutando e debatendo. A última categoria, de sistematização, explora os limites do contexto de investigação exatamente como meio de verificar como o processo de apropriação do conceito foi 
realizado; as perguntas instigam o aluno a explicar, explorar suas conclusões, apropriarse do conceito e internalizá-lo, passando a trabalhar com ele.

Em suma, trata-se de uma classificação situada no processo discursivo emergente de uma atividade de investigação, portanto passível de se aplicar para tentar entender os caminhos pelos quais os estudantes podem construir melhor seu conhecimento científico.

Com essa ferramenta analítica nas mãos, olharemos agora aulas investigativas de Física para verificar como as perguntas aparecem, suas funções e relações com a aula. Conforme pudemos observar no processo de construção, para realizar esta análise temos que estabelecer os critérios de seleção de aulas, episódios, transcrições e classificações que estejam de acordo com nossa ferramenta analítica para, assim, garantir a validade dos dados. Esclarecemos, a seguir, qual nossa metodologia de pesquisa. 


\section{Metodologia de pesquisa}

Nossa pesquisa tem caráter qualitativo, buscando analisar as interações discursivas com foco nas perguntas realizadas pelo professor em aulas de Física do Ensino Médio que envolvam a resolução de problemas pelos alunos, e analisar também os indicadores de alfabetização científica que eles apresentam no curso da atividade. A análise privilegia as perguntas do professor e os indicadores de $\mathrm{AC}$ dos alunos de modo a classificá-los de acordo com as respectivas categorias. Para as perguntas do professor, utilizaremos as categorias construídas por nós e, para as falas dos alunos, utilizaremos os indicadores de AC (SASSERON, 2008).

O método qualitativo de pesquisa é muito utilizado em pesquisas educacionais e, conforme sugere Erickson (1998), é especialmente apropriado quando se pretende, entre outras coisas, identificar nuances do entendimento subjetivo que motiva os vários participantes (p.1155). Nesse sentido, não esperamos generalizar comportamentos e atitudes, mas tecer um panorama de como esses dois fatores se encontram e se relacionam durante a investigação de um problema Físico, privilegiando aspectos e pormenores discursivos do trabalho em sala de aula que elucidem possíveis contradições e/ou incompreensões, as quais uma análise do tipo quantitativa poderia não ser capaz de responder.

De modo mais específico, para analisar as interações discursivas em uma sala de aula, como intentamos neste trabalho, localizamo-nos na perspectiva de uma pesquisa qualitativa que analisa o discurso tendo como pressuposto as relações entre linguagem e pensamento (VYGOTSKY, 2000) e significação (BAKTHIN, 2000), nas quais é possível inferir, pela localização das interações discursivas em seus contextos, como estão se construindo conceitos em sala de aula. Nesse sentido, os resultados da investigação vão além das descrições, da natureza e do conteúdo das ideias que os sujeitos possuem. Analisar o discurso é discutir os processos pelos quais essas ideias são propostas negociadas, defendidas e questionadas (MARTINS, 2006).

Embora seja um pouco distinta, a pesquisa com interações discursivas não deixa de ser qualitativa, conforme apontamos acima, no sentido exposto por Erickson (1998), na medida em que se desenvolve uma documentação dos eventos e a identificação dos significados contidos neles.

Em consonância com a base referencial de nossa pesquisa, defendemos a 
construção de significados localizada sociohistoricamente (Bakhtin, 2000), e esta concepção carrega consequências para a metodologia que se aplica na pesquisa. "Estas perspectivas", elucida a pesquisadora Isabel Martins:

"conduzem a uma visão de ensino e aprendizagem de Ciências envolvendo uma segunda socialização ou enculturação em subcomunidades, bastante diferente de visões que tratam o ensino como transmissão ou a aprendizagem como um processo de desenvolvimento cognitivo autônomo. A aprendizagem é recontextualizada como construção de sentidos e as análises das interações discursivas revelam como professor e estudantes negociam novos significados em um processo comunicativo no qual perspectivas culturais diferentes se encontram em um processo de crescimento mútuo." (Martins, 2006, p. 03)

Nossa metodologia de pesquisa obedecerá aos limites impostos pela visão de construção e negociação dos significados presentes nas categorias construídas na no item anterior e pela definição de pergunta por nós elaborada e utilizada, as quais delimitarão o recorte de validade advindo da resposta às seguintes questões centrais:

Quais os tipos de perguntas feitas pelo professor em uma aula de Física em que os alunos resolvem um problema? Que tipo de contribuição as perguntas podem trazer para um ensino que vise à $A C ?$

Buscaremos, para chegar às respostas das nossas perguntas de pesquisa, analisar um conjunto de dados obtidos pela transcrição dos discursos orais expressos em aulas gravadas em vídeo. Estas são oriundas de uma dissertação (Barrelo Jr, 2010) cuja investigação também se deu em torno das interações discursivas em aulas investigativas de Física. Para tanto, ao olharmos os dados, devemos considerar as perguntas do professor conforme nossa classificação expôs. Este delineamento busca atender à validade dos dados possíveis de serem analisados de acordo com nossos propósitos.

É importante para a nossa análise considerar as gravações em vídeos e as transcrições em texto obtidas a partir da aplicação da SEI, pois esses itens circunscrevem o contexto de negociação dos significados nas aulas. Nem sempre uma enunciação escrita na transcrição compreende exatamente o que o aluno quis expressar. $O$ áudio e o vídeo ajudam na interpretação dos dados para categorizar os tipos de perguntas ocorridas 
durante a aula. A imagem e o áudio podem mostrar um gesto ou uma entonação que a transcrição não anuncia. O mesmo é válido para os significados negociados. Sem um conhecimento prévio da SEI trabalhada não se pode saber se uma palavra está ou não expressando um conceito, no curso do trabalho investigativo.

\subsection{A constituição metodológica dos dados com base nas perguntas de investigação}

Para buscar uma resposta às nossas perguntas de pesquisa, delimitaremos quais os procedimentos de análise para esta investigação. As SEI analisadas já serviram de corpus para um trabalho realizado no LaPEF, cujos propósitos, ainda que voltados para aspectos do ensino e da aprendizagem da Física, eram diferentes dos nossos. Buscando verificar especificamente as perguntas feitas pelo professor e os indicadores de AC dos alunos, utilizaremos os materiais já gravados e transcritos.

Os dados têm relação com os objetivos de nosso trabalho, pois tratam do estudo de aulas de Física no Ensino Médio, com atividades problematizadoras de sequências de ensino investigativo (SEI) desenvolvidas com sucesso em relação à aprendizagem dos alunos. É uma SEI aplicada ao terceiro ano e o tema é previsto e proposto nos $\mathrm{PCN}+{ }^{3} \mathrm{da}$ Física. Para cada uma das aulas selecionadas analisaremos as perguntas realizadas pelo professor, os indicadores de alfabetização científica apresentados pelos alunos e as interações discursivas que nela ocorrem de acordo com nossos pressupostos teóricos e nossa categorização teórica construída.

O trabalho de pesquisa de Barrelo Jr analisou uma SEI de Física Moderna, versando sobre dualidade onda-partícula. $\mathrm{O}$ autor adaptou a sequência do trabalho de Brockington (2005) elaborando um conjunto de 11 aulas expostas no anexo A. A proposta remodelada foi discutida no grupo de pesquisa (LaPEF) a fim de explicitar os objetivos das aulas, recursos didáticos e discussões.

Os dados foram coletados em uma escola pública vinculada à Universidade de São Paulo, onde as aulas de Física são realizadas em um laboratório com instalações como bancadas de alvenaria, água, gás e rede elétrica. No centro, distribuem-se as cadeiras universitárias onde os alunos se sentam nas aulas expositivas ou de discussão.

Em linhas gerais, essa SEI sobre dualidade onda-partícula explora a contradição dos

\footnotetext{
${ }^{3}$ Parâmetros Curriculares Nacionais
} 
modelos clássicos de explicação da natureza da luz a fim de verificar que os modelos não explicam alguns fenômenos envolvendo a luz em sua totalidade, sendo necessário um novo modelo. São utilizados Interferômetros de Mach-Zenhder e simuladores para observar o comportamento da luz e problematizar com os alunos o fato de um fóton único gerar um padrão de interferência. E, a partir de então, explorar as quatro linhas interpretativas da mecânica quântica (ondulatória, corpuscular, dualista-realista e complementaridade). Inicialmente, os alunos passam por uma discussão sobre o efeito fotoelétrico, além de também já terem discutido ao longo do ano fenômenos relativos à luz como interferência, reflexão e difração. Na sequência, esses conceitos são retomados e situações são criadas para problematizar o fato de que os modelos conhecidos da natureza da luz não explicam alguns fenômenos relativos a ela de forma satisfatória. Após o problema da incompatibilidade entre os modelos e os fenômenos observados, manuseia-se o interferômetro de Mach-Zenhder real e o simulador visando a entender o comportamento da luz no interferômetro. Posteriormente, discutem-se as possibilidades de fótons únicos no interferômetro, introduzindo os problemas conceituais nos quais os modelos explicam um ou outro fenômeno, mas nenhum consegue explicar todos. Discute-se, então, a dualidade onda-partícula para, ao término, debater sobre as quatro interpretações da mecânica quântica e como elas explicam os fenômenos vistos no interferômetro (interferência para um único fóton). A aplicação de toda a SEI ocorreu ao longo de 11 aulas e algumas delas se desenvolveram como aulas duplas.

Escolhemos para a análise as aulas 2 e 10 da SEI. A aula 10 compreende também a aula 11, pelo fato de, no dia, ter havido possibilidade de utilizar o tempo de duas aulas. Porém, para fins da análise, chamaremos apenas de aula 10. Como nosso objetivo é analisar a fala do professor e dos alunos, buscamos as aulas em que há diálogo constante e clareza na captação de áudio e vídeo. Por esse motivo, as duas aulas a serem analisadas são as que nos oferecem esses requisitos.

Cada aula foi dividida em partes que chamamos de momentos. Eles são a base para a seleção dos dados analisados e são, neste trabalho, partes da aula em que há uma situação dialógica na qual as ações do professor estão voltadas para um objetivo específico. Um momento pode ser uma introdução, uma discussão sobre um experimento, uma problematização, uma exploração de informações de um quadro, etc. Dentro de cada um destes momentos teremos pequenos recortes de turnos, em que há uma cadeia enunciativa pequena, em torno de uma discussão. Ou seja, um momento pode ter a duração, por exemplo, de 100 turnos de falas transcritas por se tratar de uma discussão 
entre professor e alunos sobre uma mesma ideia. Dentro de cada momento, faremos um recorte de alguns turnos que possam ilustrar nossa análise. Em todos os momentos analisaremos as perguntas do professor de acordo com as nossas categorias e com os indicadores de AC dos alunos segundo Sasseron (2008).

A classificação de todos os turnos de acordo com as categorias seguirá de uma análise conjunta com o grupo de pesquisa sobre. De forma que todas as classificações sejam, ao menos revistas por mais de 3 pessoas, afim de se ter uma discussão e embasamento para atribuir àquela pergunta a categoria proposta e às respostas dos alunos os indicadores correspondentes.

\subsubsection{Os limites dos dados e os procedimentos de conformação destes à análise}

O fato de os dados serem oriundos de outra pesquisa carrega a perspectiva construída no seio da investigação proposta e, portanto, distinta da nossa. Entretanto, o que utilizaremos para a análise serão os dados em vídeo e as transcrições em conjunto com a proposta das sequências. Nosso objeto de análise são as perguntas do professor em relação aos indicadores de alfabetização científica e, para tal, o conjunto de dados disponível atende à nossa necessidade.

Devemos ressaltar ainda, que, frente à definição de pergunta construída nesta pesquisa, deveremos distinguir, nas transcrições já existentes, o que é uma pergunta válida para análise de uma expressão de entonação com pontuação interrogativa durante as falas. Em suma, nem sempre será a presença de um ponto de interrogação na transcrição que tornará a fala transcrita em uma pergunta tal qual definimos aqui. Do mesmo modo, pode ocorrer uma pergunta sem uma pontuação interrogativa.

Como foi discutido anteriormente, entendemos a pergunta como:

Um instrumento dialógico de estímulo à cadeia enunciativa. Sendo assim usado com propósito didático dentro da história da sala de aula para traçar e acompanhar a construção de um significado e de um conceito.

A partir disso, as transcrições do trabalho original foram reconstruídas. Esse processo foi feito com o acompanhamento simultâneo da transcrição original e do vídeo, 
apontando e destacando quais são as perguntas relevantes à análise. A título de exemplo, muitas vezes os professores têm o hábito de falar com a sala de aula com afirmações seguidas de confirmação - "Nós vamos fazer isso, tá?". Essa expressão, embora carregue corretamente o sinal de interrogação, pode não ser uma pergunta no sentido proposto por nós, caso verifiquemos se tratar somente de um hábito, ou uma forma de manter a atenção dos alunos. Assim, com as transcrições refeitas com base nos vídeos e na estrutura de elaboração da sequência e da aula, teremos o conjunto de dados a serem analisados. Essa análise, sobre a qual discorreremos, deve munir nossas evidências na busca pelas respostas às perguntas de pesquisa. Para cada uma delas, um requisito metodológico deve ser lembrado.

4.1.2 Quais os tipos de perguntas feitas pelo professor em uma aula de Física em que os alunos resolvem um problema?

Para investigar essa questão, utilizaremos as categorias teóricas construídas a priori, baseadas em trabalhos cujo foco consona com o ensino investigativo em Ciências e com as interações discursivas. Devemos, portanto, verificar em análise se essas categorias são válidas.

$\mathrm{Na}$ análise, destacaremos dentro da transcrição quais são as perguntas relevantes para serem classificadas, faremos uma breve descrição do sentido da pergunta no contexto da aula e a reformularemos de forma mais clara, colocando elementos presentes no espaço, no gesto ou no contexto em que o professor enuncia a pergunta e que não ficam nítidos somente com a transcrição da frase. A reformulação da pergunta não muda o seu sentido, ao contrário, busca deixá-la mais clara, dentro do padrão da norma culta e da estrutura morfossintática. Faremos isso deixando a pergunta com os elementos essenciais de uma oração - sujeito, predicado, verbo e objeto - sempre que possível. Dessa forma, temos uma pergunta contextualizada e mais clara, apenas para facilitar a classificação.

4.1.3 Que tipo de contribuição as perguntas podem trazer para um ensino que vise à AC?

Ao fazer a correlação entre as perguntas do professor feitas durante a aula 
investigativa dentro da SEI e os consequentes indicadores de alfabetização científica, estabelecemos uma relação causal embasada no conceito de dialogia de Bakthin (2000). Ou seja, a enunciação carrega um senso de responsividade e a resposta dos alunos é a expressão externa que dá continuidade à cadeia enunciativa. Como a pergunta do professor é dotada de propósito, essa relação causal caminha no sentido da construção de significados relativos à aula e à SEI, assim como a construção de elementos da AC. Como analisamos os indicadores de alfabetização científica levantados na interação com o professor, nos atentamos aos elementos discursivos apresentados pelos alunos que nos permitem inferir sobre as possibilidades argumentativas destes ao levantar hipóteses, apresentar justificativas, explicações, etc. Esse desenvolvimento é somente possível pela interação dialógica constante entre professor-alunos e alunos-alunos na aula.

Estabelecida essa relação causal, nossa análise buscará identificar os pares mais comuns de perguntas-indicadores, a fim de perceber relações no desenvolvimento de aspectos da alfabetização científica. Percebendo que pode haver uma relação entre determinadas perguntas realizadas pelo professor e indicadores de AC característicos, podemos compreender a pergunta como promotora de determinados indicadores em momentos diferentes da investigação. Por isso separamos as aulas investigativas em momentos específicos.

Como tratamos de aulas investigativas em nossa escolha da SEI a ser analisada e esta promoveu elementos da alfabetização científica dos alunos -, temos mais um elemento para estabelecer a relação entre o comportamento discursivo do professor e suas perguntas com o desenvolvimento da AC. Podemos, assim, contribuir para um ensino baseado na prática investigativa, problematizadora e que vise à $A C$. 


\section{Análise}

Conforme mencionamos no capítulo de metodologia de pesquisa, iniciaremos nossa análise pela aula 2 e, posteriormente, analisaremos a aula 10.

\subsection{Aula 2: o nascimento da Física Quântica.}

Esta aula tem como objetivo contextualizar um dos fatos relativos ao nascimento da Física Quântica: o problema da necessidade de adaptação da teoria aos dados experimentais. O fenômeno do efeito fotoelétrico expõe uma característica da luz corpuscular, o que contrasta com outros fenômenos também relativos à luz, como a interferência, que só é possível explicar tomando o modelo ondulatório da luz, estudado pelos alunos anteriormente. Para abordar o problema de adaptação da teoria existente aos dados experimentais novos, o professor inicia a aula relembrando conceitos, como 0 de ondas eletromagnéticas e as observações do efeito fotoelétrico realizadas com o simulador em outras aulas do curso, anteriores à implementação da SEI. Como a experiência do efeito fotoelétrico fez com que os alunos vissem a luz com um comportamento análogo ao de uma partícula, os dois modelos físicos da luz em questão na aula são o ondulatório e o corpuscular. Com uma apresentação em PowerPoint, o professor discute quatro situações relacionadas à luz para discutir quais modelos explicam as situações: 1) se a luz fosse uma partícula, os possíveis eventos gravitacionais que agem sobre ela; 2) uma reflexão de luz em um espelho; 3) um feixe de luz passando por duas fendas (interferência); 4) efeito fotoelétrico.

Esta aula apresenta um número grande de interações entre professor e alunos. São 202 turnos e cada um representa uma fala ou intervenção verbal. Dividimos a aula em quatro momentos principais: 1) a organização da sala e a lembrança das aulas anteriores e a introdução da aula; 2) retomada e discussão de conceitos e fenômenos envolvidos (efeito fotoelétrico e interferência); 3) investigação de situações clássicas (luz sob ação da gravidade, interferência, efeito fotoelétrico, reflexão); 4) problematização: se 
as explicações clássicas não dão conta de explicar todos os fenômenos, o que deve ser a luz?

Momento 1: Organização da aula, lembrança das aulas anteriores e introdução da atividade

O primeiro momento se estende do turno 01 ao turno 08, nos quais o professor organiza a sala de aula. Os alunos estão conversando bastante. Em um dado instante, o professor muda um aluno de lugar e ameaça tirá-lo da sala. Estabelecido o silêncio, o professor retoma os temas discutidos em aulas anteriores e explicita o roteiro da aula dizendo o que será trabalhado.

\begin{tabular}{|c|c|c|c|c|c|}
\hline$T$ & Falas transcritas & Desc. & $\begin{array}{l}\text { Reformul } \\
\text { ando a } \\
\text { pergunta }\end{array}$ & Clasf & \begin{tabular}{|l} 
Ind. \\
de \\
AC
\end{tabular} \\
\hline 1 & $\begin{array}{l}\text { Prof.: No nosso último encontro, é, nós respondemos a algumas questões. Olha, } \\
\text { pessoal, eu vou contar com a colaboração, caso contrário nós sentaremos em ordem } \\
\text { numérica, certo Joe? Então, no nosso último encontro a gente respondeu algumas } \\
\text { questões sobre o efeito fotoelétrico, e aí ao invés da gente já trazer as respostas } \\
\text { direto daquelas questões, nós vamos fazer uma pequena passagem, ou a gente } \\
\text { pode pular isso também, porque acho que vocês já tão "experts". }\end{array}$ & & & & \\
\hline 2 & Danilo:Por favor não & & & & \\
\hline 3 & $\begin{array}{l}\text { Prof.: Quando vocês quiserem a gente começa, ou se não quiserem eu já fiz } \\
\text { chamada, podem ir. Danilo tudo bem aí? Bom então vamos supor que todos vocês } \\
\text { entenderam, eu vou passar rapidamente pela apresentação, se alguém tiver dúvida, } \\
\text { para, se não tiver dúvida a gente vai em frente, ao final dessa aula eu passo uma } \\
\text { outra seqüência de exercícios pra vocês, ok? Muito bem. Então, o que nós faremos } \\
\text { nessa aula é... a gente revisitar o que a gente estudou ao longo desse ano pra gente } \\
\text { chegar até o efeito fotoelétrico, tá? Tá dando pra ler aí? É que a gente não pode } \\
\text { apagar completamente se não a câmera não consegue filmar vocês, tá. O que ficar } \\
\text { muito em dúvida, num momento que precisar ficar mais claro a gente apaga nesse } \\
\text { momento. Então, o que a gente viu até agora? }\end{array}$ & & & & \\
\hline 4 & Luis: Não dá pra enxergar... & & & & \\
\hline 5 & Prof.: Calma que eu leio. & & & & \\
\hline 6 & A3 (não identificado): Apaga a luz. & & & & \\
\hline 7 & $\begin{array}{l}\text { Prof.:Vou repetir que você não prestou atenção, a gente não pode apagar a luz } \\
\text { porque se apagar a luz a câmera não consegue filmar vocês no escuro, então } \\
\text { quando for necessário a gente apaga pra visão específica do quadro que for } \\
\text { necessário, se não a gente vai ler com vocês. O Joe, faz uma gentileza pra mim } \\
\text { senta na bancada ou pode sair. Mais alguém? Então, nós vimos um pouquinho de } \\
\text { modelos, quando a gente discutiu modelo a gente discutiu os modelos que a física } \\
\text { usa pra explicar a natureza das coisas, onda ou partícula, a gente verificou as } \\
\text { propriedades elétricas e magnéticas da matéria. Quando a gente começou a estudar } \\
\text { essas propriedades elétricas e magnéticas a gente falou então e discutiu um } \\
\text { pouquinho sobre a indução de campos, particularmente campo elétrico e campo } \\
\text { magnético. Depois a gente começou a estudar ondas, e aí a gente foi ver as } \\
\text { propriedades das ondas, o que definia uma onda, quais as características que uma } \\
\text { onda apresenta, a gente estudou depois luz, depois de luz a gente foi verificar os } \\
\text { espectros, e aí a gente se deparou com dois tipos de espectros, contínuos e } \\
\text { discretos, e pra explicar o modelo... pra explicar os espectros discretos a gente foi } \\
\text { então fazer uso do modelo atômico de Bohr. E aí nas duas últimas aulas a gente tá } \\
\text { conversando um pouquinho sobre o efeito fotoelétrico. Pra verificar se a gente tá } \\
\text { lembrando as coisas vamos dar uma pequena passadinha por esses diversos } \\
\text { tópicos. Então a gente quer chegar na discussão de dualidade onda-partícula, e pra } \\
\text { chegar a isso a gente começou discutindo o que são ondas, certo? Então, o que } \\
\text { definia, o que caracterizava pra gente onda? Uma onda transporta energia, sem que } \\
\text { haja transporte de matéria, ela não é... ela se espalha, não tá bem localizada. E a } \\
\text { gente tem dois fenômenos bastante associados às ondas que são os fenômenos da }\end{array}$ & $\begin{array}{l}\text { As expressões } \\
\text { interrogativas } \\
\text { que aparecem } \\
\text { neste turno são } \\
\text { automaticamen } \\
\text { te respondidas } \\
\text { pelo professor } \\
\text { de modo que } \\
\text { não as } \\
\text { consideramos } \\
\text { perguntas para } \\
\text { nossa análise. }\end{array}$ & & & \\
\hline
\end{tabular}


Tabela 11: transcrição do momento 1 da aula 2

Podemos observar que esse momento da aula não apresenta discussão sobre um conteúdo específico. Apenas uma introdução e retomada dos assuntos com os alunos. Sem a discussão sobre os conceitos, não há ainda a possibilidade de construção de significados. Não há perguntas com oportunidade dos alunos dialogarem. Aqui, o professor está explanando outros assuntos, preparando e anunciando as atividades do dia.

Embora não haja perguntas a serem classificadas ou indicadores neste momento, é importante para o bom desenvolvimento da aula esse momento de gestão do espaço, de organização do ambiente e anunciação das atividades para que os alunos possam ter ciência do que será tratado e quais informações e conceitos internalizados serão necessários para a discussão.

Momento 2: Retomada e discussão de conceitos e fenômenos ópticos (interferência, efeito fotoelétrico)

O segundo momento se inicia no turno 09 indo até o 61. Após relembrar os temas estudados em outras aulas, o professor retoma conceitos importantes para o entendimento do problema proposto para a aula sobre a natureza da luz, como espectro contínuo e discreto, e o efeito fotoelétrico. Nessa retomada, ele faz muitas perguntas aos alunos.

Selecionamos dois recortes deste momento para ilustrar as interações predominantes em relação às perguntas do professor e aos indicadores de AC. A classificação completa está no anexo B. O professor retoma conceitos necessários para o desenvolvimento da aula e o faz por meio de perguntas de sistematização, que, neste caso, objetivam saber o que os conceitos representam para os alunos. No cômpito dos indicadores de alfabetização científica, a maior ocorrência são de indicadores de explicação (5), organização de informações e justificativa (3).

No início da aula, ao falar da natureza da luz, o professor pergunta diretamente, no turno 09, "O que é um espectro contínuo de luz?". Essa é uma pergunta de 
sistematização, que exige resposta mediante o conhecimento construído pelos alunos em aulas anteriores. Essa pergunta não remete a uma articulação da observação ou a um processo, simplesmente requer uma resposta conceitualmente correta. Em resposta, os alunos respondem que não sabem definir. Então o professor pede um exemplo e, no turno 20, a aluna Clara reponde "Arco íris". O que se sucede está expresso no recorte do turno 21 ao 26:

\begin{tabular}{|c|c|c|c|c|c|}
\hline $\mathbf{T}$ & Falas transcritas & Descrição & $\begin{array}{l}\text { Reformulando a } \\
\text { pergunta. }\end{array}$ & Classificação & $\begin{array}{l}\text { Indicador } \\
\text { de AC }\end{array}$ \\
\hline 21 & Prof.: O arco íris. Por que que é contínuo? & $\begin{array}{l}\text { Retomando conceitos. } \\
\text { Busca uma explicação } \\
\text { da aluna sobre a } \\
\text { continuidade do arco iris }\end{array}$ & $\begin{array}{l}\text { Por que o arco iris } \\
\text { tem um espectro } \\
\text { de luz contínuo? }\end{array}$ & $\begin{array}{l}\text { Pergunta de } \\
\text { sistematização }\end{array}$ & \\
\hline 22 & $\begin{array}{l}\text { Clara: Porque é uma seqüência. Você não } \\
\text { tem um "buraco" sem... luz. Fica tudo } \\
\text { junto, vai passando gradualmente de uma } \\
\text { cor pra outra. }\end{array}$ & & & & Justificativa \\
\hline 23 & Prof.: Não tem o que GILBERTO? & $\begin{array}{l}\text { Quer saber o que o } \\
\text { aluno quis dizer com } \\
\text { "buraco". }\end{array}$ & & & \\
\hline 24 & $\begin{array}{l}\text { Gilberto: Não, é que nesse não tem } \\
\text { interferência. }\end{array}$ & & & & Justificativa \\
\hline 25 & Prof.: Interferência do que? & $\begin{array}{l}\text { Quer que o aluno se } \\
\text { expresse melhor }\end{array}$ & & & \\
\hline 26 & Gilberto: Do espectro contínuo.... & & & & Explicação \\
\hline
\end{tabular}

Tabela 12: recorte entre turnos 21 a 26 do momento 2 da aula 2

Ao observarmos a pergunta de sistematização do professor no turno 21 , verificamos, em resposta a ela, justificativas e explicações por parte dos alunos. No turno 21, o professor pergunta "por que o arco iris é um exemplo de espectro contínuo da luż. Essa pergunta envolve o conhecimento do conceito de espectro contínuo e necessita de uma justificativa para aquele exemplo, que é apresentada pela aluna Clara. Nesse caso, a pergunta de sistematização buscou explorar um conceito já visto em outras aulas e os alunos justificaram aquele exemplo como espectro contínuo. As perguntas de sistematização são específicas acerca de um conhecimento existente, e as respostas dos alunos podem, muitas vezes, ser dotadas apenas do conceito ou da informação requerida, ou da justificativa de uma colocação.

Com informações já discutidas e conceitos anteriores retomados, o professor apenas ajuda a relembrar a diferença entre espectro contínuo, espectro discreto e efeito fotoelétrico por meio de perguntas de sistematização. Em resposta, os alunos se veem diante de uma pergunta a partir da qual devem buscar a informação, explicar, justificar e organizar as informações para o decorrer da aula. São exemplos dessa relação os 
turnos 21, 29 e 33, nos quais o professor pergunta o que é um espectro discreto (29) e o que é o efeito fotoelétrico (33). Parece-nos claro neste início a necessidade de perguntas de sistematização para retomar conceitos e ter a possibilidade de construir o problema que será trabalhado. As perguntas mais diretas como "o que é isso?" aparecem.

$\mathrm{Na}$ sequência da discussão, separamos um segundo recorte deste segundo momento em que, no turno 33, o professor recorre à imagem do efeito fotoelétrico visando a lembrar os alunos desse conceito. A imagem é apresentada com a ajuda de um slide em PowerPoint, para que os alunos acompanhem a retomada.

\begin{tabular}{|c|c|c|c|c|c|}
\hline$T$ & Falas transcritas & Descrição & \begin{tabular}{|l|}
$\begin{array}{l}\text { Reformulando a } \\
\text { pergunta. }\end{array}$ \\
\end{tabular} & Classificação & $\begin{array}{l}\text { Indicador } \\
\text { de AC }\end{array}$ \\
\hline 33 & $\begin{array}{l}\text { Prof.: Tá fala. Isso? E aí a gente tem alguns } \\
\text { exemplos que a gente observou lá da luz } \\
\text { vinda de alguns lugares. E a gente tinha visto } \\
\text { lá também a diferença entre espectro de } \\
\text { emissão e de absorção, né? Bom, aí surge } \\
\text { esse fenômeno que a gente discutiu nas duas } \\
\text { ultimas aulas que é o efeito fotoelétrico. O } \\
\text { que é efeito fotoelétrico Virgínia?* } \mathrm{O} \text { desenho } \\
\text { ajuda vocês olha... o que tá acontecendo? }\end{array}$ & 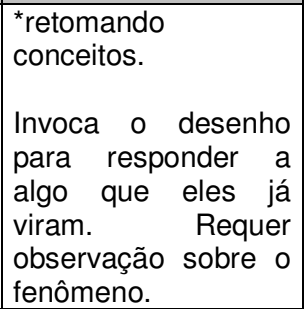 & $\begin{array}{l}{ }^{*} \mathrm{O} \text { que é o efeito } \\
\text { fotoelétrico? } \\
\text { De acordo com o } \\
\text { desenho o que } \\
\text { acontece no efeito } \\
\text { fotoelétrico? }\end{array}$ & $\begin{array}{l}\text { *Pergunta de } \\
\text { sistematização } \\
\text { Perguntas } \\
\text { sobre dados }\end{array}$ & \\
\hline 34 & $\begin{array}{l}\text { Luis: A luz tá batendo numa placa de metal e } \\
\text { no metal tá tendo emissão de elétrons... é... } \\
\text { acho que é elétrons mesmo. }\end{array}$ & & & & Explicação \\
\hline 35 & $\begin{array}{l}\text { Prof.: Tá, então eu faço incidir no metal um } \\
\text { feixe de luz, quando a luz bate nesse metal } \\
\text { alguns elétrons são emitidos }\end{array}$ & & & & \\
\hline 36 & $\begin{array}{l}\text { Gilberto: Mas na explicação, professor, } \\
\text { dependendo da luz batia e ia elétrons, } \\
\text { dependendo da luz batia e não ia elétrons }\end{array}$ & & & & Justificativa \\
\hline
\end{tabular}

Tabela 13: recorte entre os turnos 33 a 36 do momento 2 da aula 2

Os alunos, diante da pergunta de sistematização "o que é o efeito fotoelétrico" (T 33), apresentam uma explicação citando o desenho e retomando a experiência anterior para responder à pergunta do professor. Esta requer uma resposta definitiva, articulada, que defina tal fenômeno uma vez que essa ideia já foi discutida em aulas anteriores. Embora os alunos tenham estudado tal fenômeno, o professor utiliza o desenho da apresentação para direcionar a resposta dos alunos com base na representação disposta. Com isso, no turno 34, Luis explica o fenômeno utilizando elementos da imagem e elementos de conhecimento próprio (elétrons). O professor confirma a explicação (T 35). Logo em seguida, Gilberto complementa a resposta com uma justificativa colocando o adendo de que nem sempre há emissão de elétrons e que isso dependerá do "tipo" de luz que é incidida. Nota-se, então, uma retomada por parte dos alunos de conceitos e fenômenos estudados anteriormente, e a pergunta de sistematização do professor 
estimula essa lembrança.

Momento 3: Investigando situações clássicas (luz sob ação da gravidade, interferência, efeito fotoelétrico, reflexão da luz) para aplicar um modelo explicativo

O terceiro momento da aula transcorre entre os turnos 62 e 171. Após buscar relembrar os conceitos de interferência, reflexão e efeito fotoelétrico, no turno 62 , 0 professor introduz o problema central a ser trabalhado: "A luz é onda ou é partícula?". Todo o processo de sistematização sobre as experiências e saberes anteriores dos alunos contribui para o esclarecimento do problema e o desenvolvimento da aula no seu terceiro momento, iniciado no turno 62.

Conforme explicitado, o objetivo da aula é o problema de adaptação da teoria conhecida para o comportamento da luz aos dados experimentais observados. Para isso, o professor relembra dois aspectos (teoria anterior e exemplos experimentais) que os alunos já viram sobre as situações envolvidas a fim de se construir o problema do comportamento dual da luz. Então, o professor explora as situações clássicas da reflexão da luz em um espelho - da interferência da luz, do efeito da gravidade em um fóton de luz e do efeito fotoelétrico - a fim de aplicar os modelos existentes para tentar explicar os conceitos trabalhados no momento anterior. Devemos lembrar que chamamos essas situações de clássicas em oposição ao conhecimento da Física Moderna sobre os fenômenos em questão.

Separamos para a análise dois recortes entre os 109 turnos deste momento da aula para ilustrar a forma predominante como ocorrem as perguntas do professor e os indicadores de AC dos alunos. Em números gerais, temos 32 perguntas feitas pelo professor, sendo 14 sobre dados, 7 exploratórias sobre o processo, 6 de sistematização, 5 de problematização. Os tipos de perguntas mais observados no meio da aula são as perguntas sobre dados. Em relação aos indicadores de $A C$, temos os de levantamento de hipóteses como maioria dos 32 indicadores, com 8 ocorrências, e, em seguida, a organização de informações e explicação (7), e previsão (6). Tal disposição, entretanto, se dá em relação ao tipos de perguntas distintos. 


\begin{tabular}{|c|c|c|c|c|c|}
\hline 62 & $\begin{array}{l}\text { Prof.: Ah... aquilo é só foto da época. Tudo bem? Então } \\
\text { a mecânica quântica vai surgir a partir, a mecânica } \\
\text { quântica então começa a surgir a partir dessa, do } \\
\text { estudo dessa radiação quando os corpos eram } \\
\text { aquecidos. Um físico chamado Max Planck vai } \\
\text { conseguir determinar qual é... vai chegar } \\
\text { matematicamente à observação dessa curva dos } \\
\text { espectros de radiação e aí vem o que a gente já } \\
\text { discutiu um pouquinho nas últimas aulas a questão de } \\
\text { ser... de que os valores de energia são discretos, } \\
\text { dependem da constante de Planck e tal... bom, mas } \\
\text { voltemos à nossa questão primeira, lá de fevereiro, o } \\
\text { que afinal é a luz. Continua a pergunta, é onda ou é } \\
\text { partícula? }\end{array}$ & $\begin{array}{l}\text { Refaz a } \\
\text { pergunta } \\
\text { central da } \\
\text { investigação }\end{array}$ & $\begin{array}{l}\text { A luz é onda } \\
\text { ou partícula? }\end{array}$ & $\begin{array}{l}\text { Pergunta de } \\
\text { problematização }\end{array}$ & \\
\hline 63 & A23: Não dá pra ser as duas? & & & $\begin{array}{l}\text { Pergunta de } \\
\text { problematização }\end{array}$ & $\begin{array}{l}\text { Levantamento } \\
\text { de hipóteses }\end{array}$ \\
\hline 64 & Prof.: Ãhn? & & & & \\
\hline 65 & Patrícia: Não dá pra ser as duas? & & & \begin{tabular}{|l|} 
Pergunta de \\
problematização
\end{tabular} & $\begin{array}{l}\text { Levantamento } \\
\text { de hipóteses }\end{array}$ \\
\hline 66 & $\begin{array}{l}\text { Prof.: Calma, pra gente discutir isso, se dá ou não, pra } \\
\text { saber a gente vai pensar em quatro situações. }\end{array}$ & & & & \\
\hline 67 & $\begin{array}{l}\text { Gilberto: Professor, a luz não pode ser partícula com } \\
\text { propriedades de onda? }\end{array}$ & & & $\begin{array}{l}\text { Pergunta de } \\
\text { problematização }\end{array}$ & $\begin{array}{l}\text { Levantamento } \\
\text { de hipóteses }\end{array}$ \\
\hline 68 & Prof.: Guarda essa sua pergunta pra gente discutir. & & & & \\
\hline 69 & Eduardo: Qual a pergunta dele? & & & & \\
\hline 70 & $\begin{array}{l}\text { Prof.: Ele tá dizendo assim, olha uma partícula pode ter } \\
\text { propriedades de onda? }\end{array}$ & & & & \\
\hline 71 & $\begin{array}{l}\text { Eduardo: } \hat{E} \text { isso que eu to pensando, uma bolinha, } \\
\text { sabe? }\end{array}$ & & & & $\begin{array}{l}\text { Levantamento } \\
\text { de hipóteses }\end{array}$ \\
\hline 72 & Prof.: Guarda essa sua representação também. & & & & \\
\hline 73 & $\begin{array}{l}\text { Gilberto: Eu tava conversando que pode ser uma onda } \\
\text { com propriedade de partícula, uma partícula com } \\
\text { propriedade de onda. }\end{array}$ & & & & $\begin{array}{l}\text { Levantamento } \\
\text { de hipótese/ } \\
\text { Explicação } \\
\end{array}$ \\
\hline
\end{tabular}

Tabela 14: recorte entre turnos 62 a 73 do momento 3 da aula 2

Logo após a pergunta de problematização ser lançada, no turno 62, os alunos começam a se manifestar lançando outras perguntas. A colocação do problema no turno 62 é importante para situar os alunos da contradição entre os dados observados e os modelos explicativos. O professor recorrerá a uma série de situações as quais cada modelo - corpuscular e ondulatório - não consegue explicar corretamente.

Após a pergunta de problematização ter sido feita, os alunos começam a testar possibilidades perguntando ao professor se a luz poderia ser algo diferente do que é para os dois modelos vigentes. No turno 63, imediatamente após a pergunta, Patrícia questiona: “não pode ser as duas coisas?". Essa pergunta contém uma hipótese para o professor confirmar. Ele confirma o que foi dito (T 63) e o aluno repete a hipótese (T 65). O professor, então, sabendo que o aluno está antecipando o rumo da discussão - já que a interpretação dualista-realista dirá que a luz é ao mesmo tempo onda e partícula -, pede calma e retoma ao planejamento da atividade, que é discutir as quatro situações hipotéticas.

No turno 66, o professor diz: "Calma, pra gente discutir isso, se dá ou não pra saber a gente vai pensar em quatro situações". Logo em seguida, no turno 67, a pergunta de 
Gilberto lança uma hipótese: "Professor, a luz não pode ser partícula com propriedades de onda?". Novamente, a hipótese levantada pelo aluno antecipa uma interpretação prevista da luz, a da complementaridade. O professor continua administrando a atividade sem responder ao aluno, mas solicitando que ele guarde a pergunta.

Após a dúvida surgida na pergunta de Gilberto, Eduardo levanta uma hipótese desta vez, sem perguntar diretamente ao professor, mas expressando seu pensamento. Vemos isso no turno 71: "É isso que eu tô pensando, uma bolinha, sabe?". Novamente, o professor pede para que o aluno guarde aquela representação. E sem tempo de resposta, Gilberto novamente lança mais uma hipótese, no turno 73: "Eu tava conversando que pode ser uma onda com propriedade de partícula, uma partícula com propriedade de onda". O professor, então, solicita que Gilberto anote aquele pensamento e imediatamente começa a discutir o planejado sobre as quatro situações hipotéticas.

Podemos perceber que os alunos estão engajados no problema, articulando hipóteses para tentar resolvê-lo. Entretanto, o professor seguiu os passos estruturados, exatamente para possibilitar, ao longo da aula, que os alunos tivessem mais elementos para discutir o problema.

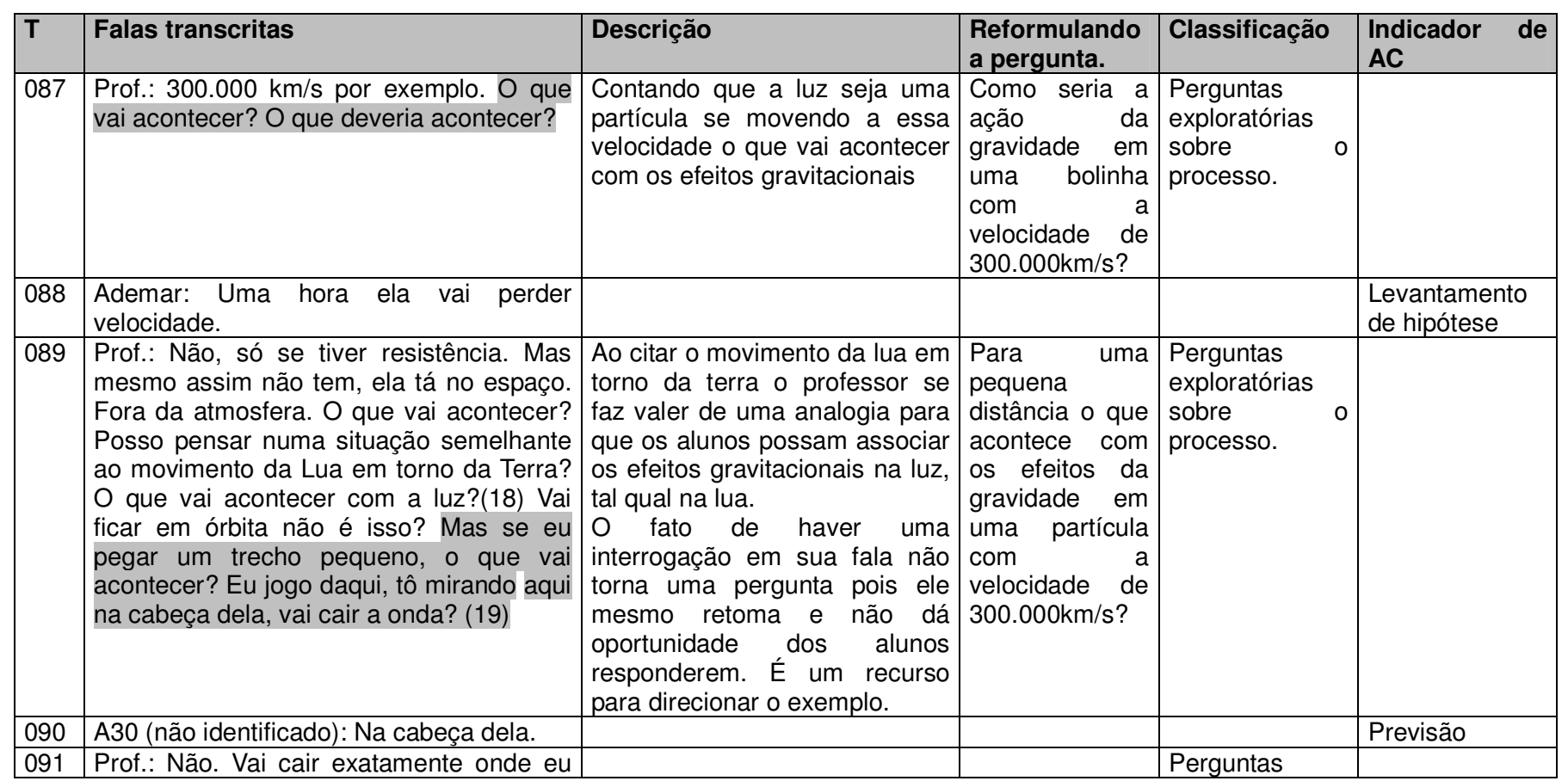




\begin{tabular}{|l|l|l|l|l|l|}
\hline & mirei? & & & $\begin{array}{l}\text { exploratórias } \\
\text { sobre } \\
\text { processo. }\end{array}$ & \\
\hline 092 & A30 (não identificado): Não. & & & Previsão \\
\hline
\end{tabular}

$\mathrm{Na}$ sequência, no segundo recorte que separamos deste momento, o professor começa a discutir efetivamente os quatro casos clássicos para entender o comportamento da luz em cada um. O primeiro caso discutido é o da luz como partícula sujeita a um campo gravitacional.

Tabela 15: turnos 87 a 92 do momento 3 da aula 2

Nesse trecho da discussão, as perguntas exploratórias sobre o processo aparecem associadas também à criação de uma situação hipotética baseada em ideias e evidências. A situação é hipotética pois não consegue medir o desvio da luz sob a ação da gravidade. Sabe-se hoje que esse desvio existe e é calculado pela geodésica, elemento central da teoria da relatividade geral de Einstein. Naquele momento, não era objetivo do professor promover essa discussão, ele apenas trabalhou um evento hipotético para conferir uma natureza corpuscular à luz.

Nos turnos 87, 89 e 91 deste recorte do terceiro momento da aula, o professor explora uma situação em que a luz é uma partícula que se desloca à velocidade de $300.00 \mathrm{~km} / \mathrm{s}$ e tenta articular com os possíveis efeitos gravitacionais agentes nesta partícula. No turno 87, a pergunta "Como seria a ação da gravidade em uma bolinha com a velocidade de $300.000 \mathrm{~km} / \mathrm{s}$ ?" traz uma situação hipotética sem evidências observáveis e, portanto, exige uma articulação de ideias em consonância com o que os alunos conhecem sobre a luz. É importante notar que, embora a equação da geodésica obtida na relatividade geral de Einstein descreva efeitos gravitacionais agindo no espaço-tempo e curvando a luz, o professor não explicita essa descrição, pois sua ideia é mais simples, ou seja, imaginar qual poderia ser a "queda" observável de um feixe de luz sob a ação da gravidade, mantida a velocidade absoluta da luz.

Diante da pergunta exploratória sobre o processo, feita pelo professor no turno 88, Ademar cria uma hipótese de que a gravidade pode desacelerar a luz, "uma hora ela vai perder velocidade". Na sequência, o professor recorre a uma analogia com o movimento da lua para que os alunos possam associá-lo ao movimento da luz. Após o uso dessa analogia, o professor cria uma nova experiência de pensamento supondo a mira do laser na cabeça de uma aluna e pergunta, no turno 89, se a onda vai cair. No turno seguinte, o aluno A30 (não identificado) responde dizendo que o laser atingirá a 
cabeça da menina. Essa resposta representa uma previsão, talvez por associar a mira laser a armas presentes em filmes, etc. E em casos como esses, vistos no dia a dia, parece não haver efeito gravitacional. O professor, então, talvez percebendo essa condição, nega a previsão de A30 (não identificado) e refaz a pergunta, desta vez com mais acurácia: "Vai cair exatamente onde eu mirei?" (T 91). A resposta imediata é do próprio A30, cuja previsão anterior foi negada: "Não".

Podemos observar desse recorte que, diante de uma situação em que os alunos não têm evidências diretas, eles criam hipóteses e previsões. O professor desenvolve, para cada exemplo de fenômeno (reflexão, interferência, efeito fotoelétrico), uma situação clássica na qual os alunos têm que demandar seus conhecimentos, observações e articulações de ideias para compreender a situação.

Após esse recorte do momento da aula, o professor passa a explorar qual tipo de modelo é mais plausível para explicar aquelas situações. Isso se dá por meio de perguntas de sistematização. Depois de todas as situações delimitadas, o problema, mais uma vez, é ressaltado: não se tem um modelo único para explicar todos os exemplos mostrados, o que acentua a importância de buscar entender a natureza da luz.

Na sequência, muitas perguntas sobre dados aparecem quando o professor está explorando os fenômenos, na medida em que os alunos, em tese, conhecem o fenômeno tratado e têm, juntamente com as imagens e exemplos do professor, dados postos para responder às perguntas.

\begin{tabular}{|c|c|c|c|c|c|}
\hline $\mathbf{T}$ & Falas transcritas & Descrição & $\begin{array}{l}\text { Reformulando } \\
\text { a pergunta. }\end{array}$ & Classificação & $\begin{array}{l}\text { Indicador } \\
\text { de AC }\end{array}$ \\
\hline 099 & $\begin{array}{l}\text { Prof.: Tem um ângulo, lógico que é. Tá aqui a mira, } \\
\text { tem um ângulo aqui, ela tá inclinada. Eu to mirando } \\
\text { aqui, se eu me afastar dele eu vou tá mirando ainda o } \\
\text { conjunto afasta junto. Então já tá previsto. Bom, mas } \\
\text { voltemos ao nosso tiro de luz aqui. Então a gente tem } \\
\text { uma distância aí da fonte até o anteparo de } 5 \mathrm{~m} \text { e pelo } \\
\text { que vocês estavam dizendo vai ter um pequeno desvio } \\
\text { pra baixo, certo? Vamos fazer de conta que a } \\
\text { velocidade da luz seja } 300.000 \mathrm{~km} / \mathrm{s} \text { e que a ação da } \\
\text { gravidade é de } 10 \mathrm{~m} / \mathrm{s}^{2} \text {, né Julia? Então a gente } \\
\text { direcionou o feixe de luz pra cá e vai abrir uma } \\
\text { distancia h aqui, uma altura h entre o ponto que a } \\
\text { gente esperava e o que a ação da gravidade vai levar } \\
\text { pra baixo, isso vai nos comprovar, se a gente fizer } \\
\text { isso, que a luz é partícula. Pensando nessa velocidade } \\
\text { da luz, pensando no raio terrestre, a luz demora um } \\
\text { décimo de segundo pra dar a volta na Terra. Então em } \\
\text { um décimo de segundo a luz dá a volta na Terra cujo } \\
\text { raio é da ordem de } 6.970 \mathrm{~km} \text {. Então significa que } 5 \mathrm{~m} \\
\text { vai ser num tempo infinitamente menor. Se isso } \\
\text { acontecesse pra gente medir dessa forma, essa } \\
\text { distância que a gente tá querendo calcular aqui como }\end{array}$ & $\begin{array}{lr}\text { Dada } & a \\
\text { suposição da } & \text { da } \\
\text { situação 1. Não é }\end{array}$ & $\begin{array}{l}\text { Posto que não } \\
\text { podemos medir } \\
\text { a queda da luz } \\
\text { pela atração }\end{array}$ & $\begin{array}{l}\text { Perguntas } \\
\text { exploratórias } \\
\text { sobre } \\
\text { processo. }\end{array}$ & \\
\hline
\end{tabular}




\begin{tabular}{|c|c|c|c|c|c|}
\hline & $\begin{array}{l}\text { desvio da luz seria de aproximadamente } 10^{-16} \mathrm{~m} \text {, ou } \\
\text { seja em } 5 \mathrm{~m} \text {, que é a distância que a gente tá medindo, } \\
\text { o desvio que a luz sofreria é de } 0 \text {, quinze } 0 \text { um atrás } \\
\text { do outro } 1 \text { metro. E pra gente comparar o diâmetro de } \\
\text { um átomo é da ordem da } 10-10 \mathrm{~m} \text { ou seja essa } \\
\text { distancia que a gente espera que dê é muito menor } \\
\text { que o diâmetro atômico, a gente não tem condição } \\
\text { então de medir com os instrumentos que a gente } \\
\text { possui hoje, pra gente ter uma noção, um livro com } \\
100,150 \text { páginas, essa espessura, tem } \\
\text { aproximadamente essa quantidade de átomos } \\
\text { enfileirados um atrás do outro. Então se a gente pegar } \\
\text { um livro com aproximadamente } 100 \text { páginas, essa } \\
\text { espessura aqui tem essa quantidade de átomos, se a } \\
\text { distância que a gente vai medir é muito menor que um } \\
\text { único átomo pra esta nossa primeira preocupação, o } \\
\text { que a gente pode inferir? Dá pra dizer que a luz é uma } \\
\text { coisa ou outra? Eu posso afirmar que a luz é } \\
\text { partícula? Mas posso afirmar que ela não seja? } \\
\text { Também não. Então pra essa nossa preocupação, se } \\
\text { a luz é partícula e ela interagir com outros corpos } \\
\text { sofrendo a ação da gravidade, sofreria um desvio e } \\
\text { esse desvio é tão pequeno que a gente não tem } \\
\text { instrumento pra medir. Então nessa primeira situação } \\
\text { a gente não consegue obter informação a respeito, } \\
\text { certo? Nessa segunda situação a luz interagindo com } \\
\text { um espelho o que acontece? Tem um espelho aqui, } \\
\text { emito um raio de luz o que vai acontecer com esse } \\
\text { raio de luz? }\end{array}$ & 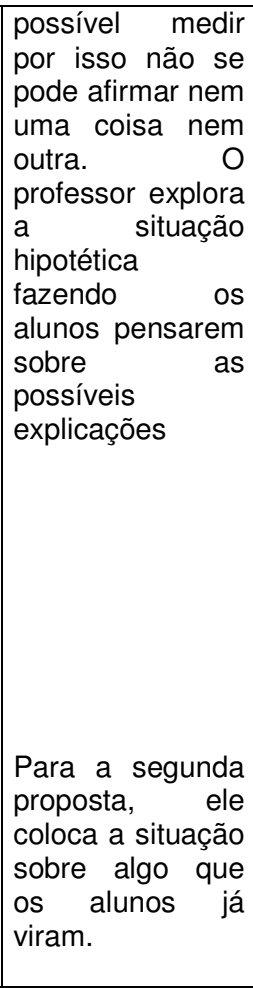 & $\begin{array}{l}\text { gravitacional, } \\
\text { podemos } \\
\text { afirmar que ela } \\
\text { é partícula? } \\
\text { Podemos } \\
\text { afirmar que ela } \\
\text { não é? }\end{array}$ & $\begin{array}{l}\text { Pergunta de } \\
\text { sistematização }\end{array}$ & \\
\hline 100 & Eduardo: Vai ser refletido. & & & & $\begin{array}{l}\text { Previsão/ } \\
\text { explicação }\end{array}$ \\
\hline 101 & $\begin{array}{l}\text { Prof.: Vai ser refletido. Qual é a condição de } \\
\text { reflexão?(25) Tem que voltar no mesmo ângulo que } \\
\text { incidiu, não é isso? Então a condição é manda um raio } \\
\text { de luz pro espelho volta no mesmo ângulo, não é } \\
\text { isso? E aí pra essa situação eu posso responder se a } \\
\text { luz for partícula a partícula bate no espelho e é } \\
\text { refletida, se a luz for onda bate no espelho e também } \\
\text { é refletida. A que conclusão a gente chega?(26) }\end{array}$ & $\begin{array}{l}\text { Busca uma } \\
\text { resposta de um } \\
\text { conceito. } \\
\text { Expõe a situação } \\
\text { em que a luz } \\
\text { pode ser as duas } \\
\text { coisas (onda e } \\
\text { partícula) pede } \\
\text { uma conclusão }\end{array}$ & $\begin{array}{l}\text { Qual a lei da } \\
\text { reflexão? } \\
\text { Se a luz como } \\
\text { onda bate no } \\
\text { espelho e } \\
\text { reflete e a luz } \\
\text { como uma } \\
\text { partícula bate } \\
\text { no espelho e } \\
\text { também reflete, } \\
\text { qual a } \\
\text { conclusão? }\end{array}$ & $\begin{array}{l}\text { Pergunta de } \\
\text { sistematização } \\
\text { Pergunta de } \\
\text { sistematização }\end{array}$ & \\
\hline 102 & Cristina: Nenhuma. & & & & \\
\hline 103 & $\begin{array}{l}\text { Prof.: Pode ser onda ou partícula, certo? Terceira } \\
\text { situação, agora eu tenho uma luz emitida por uma } \\
\text { fonte que atravessa um anteparo que tem duas } \\
\text { fendas, então vamos pensar numa chapinha, essa } \\
\text { chapinha tem dois cortes, né, duas fendas e aí algo } \\
\text { semelhante a isso aqui, certo? Então a gente tem um } \\
\text { anteparo com duas fendas e a gente faz incidir sobre } \\
\text { ele uma fonte de luz. O que vai acontecer? O que } \\
\text { acontece? Aqui é uma fenda aqui é outra fenda, } \\
\text { mesma fonte de luz, passa por aqui e aí o que vai } \\
\text { acontecer? Se a luz bater aqui [na parte onde não há } \\
\text { fenda] o que acontece? }\end{array}$ & \begin{tabular}{|lr} 
Problema & da \\
fenda. O & que \\
acontecerá & na \\
situação três. Os \\
elementos & para \\
responder & a \\
questão não são \\
evidentes & \\
Exemplificou & a \\
questão. & Para \\
direcionar o olhar \\
$\begin{array}{ll}\text { dos alunos a } \\
\text { descartar } \\
\text { variáveis }\end{array}$ \\
\end{tabular} & $\begin{array}{l}\text { O que acontece } \\
\text { quando } \\
\text { incidimos uma } \\
\text { luz em duas } \\
\text { fendas? } \\
\text { O que acontece } \\
\text { quando a luz } \\
\text { bate em um } \\
\text { objeto opaco? }\end{array}$ & $\begin{array}{l}\text { Pergunta de } \\
\text { problematizaçã } \\
0\end{array}$ & \\
\hline 104 & Nicolau: Ela passa. & & & & Previsão \\
\hline 105 & Prof.: Passa? & & & & \\
\hline 106 & Nicolau: Bate e volta. & & & & Previsão \\
\hline 107 & $\begin{array}{l}\text { Prof.:Bate e volta se o objeto for opaco, é isso? Se } \\
\text { bate aqui [no vão da fenda]?(28) }\end{array}$ & idem & $\begin{array}{l}\text { O que acontece } \\
\text { quando a luz } \\
\text { passa por uma } \\
\text { fenda? }\end{array}$ & \begin{tabular}{|l} 
Perguntas \\
sobre dados
\end{tabular} & \\
\hline 108 & Nicolau: Passa. & & & & previsão \\
\hline 109 & Prof.: Passa, vai ficar aqui assim, certo? Se bate aqui & idem & O que acontece & Pergunta sobre & \\
\hline
\end{tabular}




\begin{tabular}{|l|l|l|l|l|}
\hline & $\begin{array}{l}\text { [no vão da outra fenda]? Passa também, eu vou ter } \\
\text { outra linha aqui, certo? Posso ter um pequeno desvio } \\
\text { pra um lado ou pro outro dependendo do ângulo de } \\
\text { incidência, não é isso? Aqui então deve ser sombra, } \\
\text { não deve ter marca nenhuma, não é isso? Aquela } \\
\text { região vai ser uma região de sombra. }\end{array}$ & $\begin{array}{l}\text { quando a luz dados. } \\
\text { passa por uma } \\
\text { fenda? }\end{array}$ & \\
\hline 110 & Augusto: Só se a luz não estiver muito inclinada. & $\begin{array}{l}\text { Se o ângulo de } \\
\text { incidência nas } \\
\text { fendas não for } \\
\text { muito excêntrico }\end{array}$ & explicação \\
\hline
\end{tabular}

Tabela 16: recorte entre os turnos 99 a 110 do momento 3 da aula 2

As perguntas sobre dados referem-se a situações experimentais hipotéticas, às quais o professor recorre para perguntar aos alunos sobre os fenômenos envolvidos. É o caso verificado no turno 99: "Tem um espelho aqui, emito um raio de luz o que vai acontecer com esse raio de luz?'. Cria-se uma situação experimental hipotética, em que os alunos já conhecem os fenômenos envolvidos, e se explora o que os alunos sabem para dizer o que acontecerá. O mesmo acontece nos turnos 103, 107 e 109.

Discutindo a terceira situação clássica, sobre a interferência de luz, o professor mostra uma figura de fenda dupla e problematiza para que os alunos prevejam o que acontecerá na situação montada. Ao mesmo tempo, ele já simplifica a pergunta para uma especificidade da montagem que é prever o que acontece quando a luz se depara com a parte opaca, e ele indica com a mão: "Se a luz bater aqui [na parte que não há fenda] o que acontece?” (T 103). Essa pergunta explicita uma previsão de uma montagem simples. Nicolau responde que a luz passará e o professor então repete a sentença de Gilberto, indagando-o: "passa?” (T 105). Assim, ele nega a explicação do aluno. Tanto que, imediatamente, Nicolau fala sua previsão - "bate e volta" (T 106) - e, no mesmo momento, o professor confirma a previsão de que, naquele lugar, o objeto é opaco e a luz não atravessará, e passa para outra situação: "Se bate aqui [no vão da fenda]?" (T 107). Desta vez, eliminada a hipótese de voltar, um aluno responde corretamente à previsão: "passa".

O professor desenvolve, então, alguns casos hipotéticos para lembrar os alunos sobre o fenômeno da interferência. Como ele expõe situações simuladas, os alunos devem prever o que acontecerá em determinada situação. E é o que eles apresentam. Esse levantamento de previsibilidade será importante para o professor retomar o conceito de interferência na medida em que, por meio da observação dos dados dispostos e dos conhecimentos dos alunos sobre a luz, possibilita prever a situação para depois explorar 
que tipo de modelo da natureza da luz pode explicar o fenômeno relativo à aquela situação, que os próprios alunos concluíram.

Logo em seguida, o professor sistematiza a situação para que os alunos possam concluir sobre o modelo aplicado à situação das fendas mostrando as figuras de interferência de ondas e perguntando sobre os motivos da formação daquele padrão.

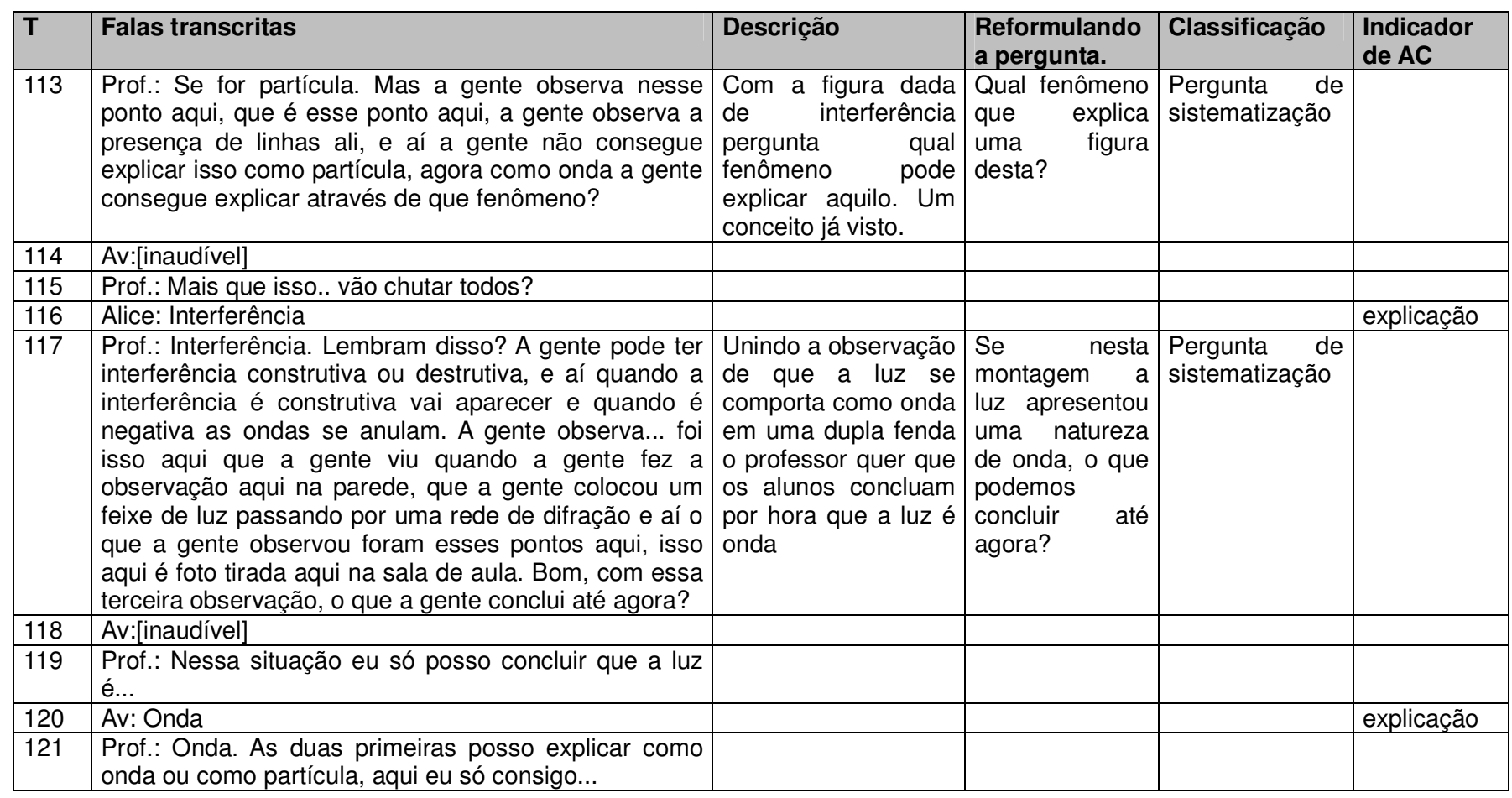

Tabela 17:recorte entre turnos 113 a 121 do momento 3 da aula 2

Aqui, algumas perguntas de sistematização aparecem seguidas, na maioria das vezes, de indicadores de explicação. O professor mostra a figura observada (de interferência), perguntando qual fenômeno explica aquele padrão - uma pergunta de sistematização para que os alunos o identifiquem. Como resposta, no turno 116, a aluna Alice responde com o fenômeno esperado: "Interferência". O professor confirma a intervenção da aluna e explana o fenômeno em questão. Em seguida, ele conclui junto aos alunos qual dos modelos para a natureza da luz explica a interferência e, no caso, ela só pode ser explicada com a luz sendo onda. Após a explanação o professor pergunta qual modelo explica a interferência ( $\mathrm{T}$ 119), e um aluno já conclui, dizendo que naquele caso a luz tem de ser onda.

Nos pequenos recortes apresentados, o professor explora uma situação com dados 
evidentes e, após ter ficado claro o exemplo, passa a fazer perguntas de sistematização para que os alunos concluam que a interferência a luz só pode ser explicada como onda (T 120).

Momento 4: Problematização - Se os dois modelos clássicos não dão conta de explicar todos os fenômenos, o que deve ser a luz?

O quarto e último momento da aula vai do turno 172 ao turno 202. Após os conceitos serem retomados no momento 2 e os exemplos de situações clássicas articularem os conceitos e os exemplos no momento 3, verifica-se uma incongruência entre os modelos ondulatório e corpuscular disponíveis e suas impossibilidades de explicar todos os exemplos dados. Essa constatação acontece no término do momento 3 e, após ela ser feita, o problema se acentua novamente, ou seja, como explicar a natureza da luz?

O quarto momento da aula é voltado ao problema que será levado para o resto da SEI: "o que é a luz?". Nesta etapa de fixação do problema, o professor recapitula os passos da aula. Ao todo, são 7 perguntas, sendo 4 de problematização e 3 de sistematização. Os alunos, por sua vez, apresentam três tipos de indicadores de AC: levantamento de hipótese (6), explicação (3) e organização de informações (2).

O recorte entre o turno 178 e 187 ilustra como o professor sistematiza a discussão com a classe para ter condições de retomar o problema da SEI e, logo após (entre os turnos 187 e 195), problematizar a questão da natureza da luz.

\begin{tabular}{|c|c|c|c|c|c|}
\hline$T$ & Falas transcritas & Descrição & $\begin{array}{l}\text { Reformulando a } \\
\text { pergunta. }\end{array}$ & Classificação & $\begin{array}{l}\text { Indicador de } \\
\text { AC }\end{array}$ \\
\hline 178 & $\begin{array}{l}\text { Prof.: Eu não acho nada. Gente, aqui } \\
\text { tem um resumo então dos fenômenos e } \\
\text { das explicações, possíveis ou não, pra } \\
\text { cada um dos dois modelos. Então nesse } \\
\text { quadrinho aqui a gente tem, né... pra } \\
\text { esses fenômenos. Olhando pra esse } \\
\text { quadro, a gente pode falar que a luz é } \\
\text { uma onda? }\end{array}$ & $\begin{array}{l}\text { Resume r as } \\
\text { situações } \\
\text { expressas nas } \\
\text { quais não se } \\
\text { explica } \\
\text { inteiramente } \\
\text { todos os casos } \\
\text { com nenhum dos } \\
\text { dois modelos. }\end{array}$ & $\begin{array}{l}\text { Observando as situações } \\
\text { e as possibilidades de } \\
\text { explicar os casos como } \\
\text { onda ou partícula, } \\
\text { podemos afirmar que é } \\
\text { uma onda? }\end{array}$ & $\begin{array}{l}\text { Pergunta de } \\
\text { sistematização }\end{array}$ & \\
\hline 179 & Diversos: Mais ou menos. & & & & explicação \\
\hline 180 & Diversos: Não. & & & & explicação \\
\hline 181 & $\begin{array}{l}\text { Prof.: Posso dizer que é uma onda? } \\
\text { Posso? }\end{array}$ & Refaz a pergunta & idem & $\begin{array}{l}\text { Pergunta de } \\
\text { sistematização }\end{array}$ & \\
\hline 182 & Av: Não. & & & & explicação \\
\hline 183 & $\begin{array}{l}\text { Prof.: Se ela é onda, ela explica tudo } \\
\text { isso aqui, certo? Explica aqui? Então } \\
\text { pode ser onda? }\end{array}$ & & $\begin{array}{l}\text { Observando as situações } \\
\text { e as possibilidades de } \\
\text { explicar os casos como } \\
\text { onda ou partícula, }\end{array}$ & $\begin{array}{l}\text { Pergunta de } \\
\text { sistematização }\end{array}$ & \\
\hline
\end{tabular}




\begin{tabular}{|l|l|l|l|l|}
\hline & & $\begin{array}{l}\text { podemos afirmar que é } \\
\text { uma onda? }\end{array}$ & \\
\hline 184 & Diversos: Não. & & explicação \\
\hline 185 & $\begin{array}{l}\text { Prof.: Porque não explica esse } \\
\text { fenômeno. Olhando pra cá, posso dizer } \\
\text { que é partícula? }\end{array}$ & $\begin{array}{l}\text { Observando as situações } \\
\text { e as possibilidades de } \\
\text { explicaros casos como } \\
\text { onda ou partácula, } \\
\text { podemos afirmar que é } \\
\text { uma partícula? }\end{array}$ & $\begin{array}{c}\text { de } \\
\text { sistematização }\end{array}$ \\
\hline 186 & Av: Não. & & & explicação \\
\hline
\end{tabular}

Tabela 18: recorte entre os turnos 178 a 186 do momento 4 da aula 2

As perguntas de sistematização são elaboradas para rever as quatro situações clássicas (fóton sobre a ação da gravidade, reflexão, interferência e efeito fotoelétrico) e concluir que não há modelo capaz de explicar todos os casos. No turno 178, o professor pergunta: "Observando as situações e as possibilidades de explicar os casos como onda ou partícula, podemos afirmar que é uma onda?". Os alunos respondem, apresentando explicações: "mais ou menos" (T 179), "não" (T 180). Ele refaz a pergunta no turno 181, obtendo a mesma resposta. Então, ele somente muda a natureza do objeto para que os alunos concluam que nenhum modelo pode explicar os fenômenos observados. No turno 185, o professor pergunta “Olhando pra cá, posso dizer que é partícula?" e a resposta vem imediatamente: "Não" (T 184).

Para as perguntas de sistematização no recorte do quarto momento, os alunos articulam o que acabaram de discutir, o quadro da apresentação do professor e o que já sabiam anteriormente para responder objetivamente ao professor, o que consideramos como explicação/conclusão.

\begin{tabular}{|c|c|c|c|c|c|}
\hline$T$ & Falas transcritas & Descrição & $\begin{array}{l}\text { Reformulando a } \\
\text { pergunta. }\end{array}$ & Classificação & $\begin{array}{l}\text { Indicador } \\
\text { AC }\end{array}$ \\
\hline 189 & $\begin{array}{l}\text { Prof.: Porque assim, se os dois modelos } \\
\text { que a gente tem explicam parte dos } \\
\text { fenômenos, e esses dois modelos são } \\
\text { excludentes. Eu posso dizer que é as duas } \\
\text { coisas? }\end{array}$ & $\begin{array}{l}\text { Reforça a conclusão } \\
\text { da aula de que não } \\
\text { se pode explicar os } \\
\text { casos com somente } \\
\text { um modelo, nem } \\
\text { com os dois. }\end{array}$ & $\begin{array}{l}\text { Observando as } \\
\text { situações e as } \\
\text { possibilidades de } \\
\text { explicar os casos } \\
\text { como onda ou } \\
\text { partícula, } \\
\text { podemos afirmar } \\
\text { que é uma } \\
\text { partícula? }\end{array}$ & $\begin{array}{l}\text { Pergunta de } \\
\text { problematização }\end{array}$ & \\
\hline 190 & Teresa: Em determinada situação... & & & & $\begin{array}{l}\text { Levantamento } \\
\text { de hipóteses/ } \\
\text { explicação }\end{array}$ \\
\hline 191 & Augusto: É intermediário. & & & & $\begin{array}{l}\text { Levantamento } \\
\text { de hipóteses/ } \\
\text { explicação }\end{array}$ \\
\hline 192 & $\begin{array}{l}\text { Prof.: Uma terceira coisa? Lembrando } \\
\text { desde o inicio lá, nossa primeira discussão } \\
\text { sobre modelo, onda e partícula são } \\
\text { excludentes. Onda tá espalhada, partícula } \\
\text { tá localizada, certo? Começa por aí, algo } \\
\text { pode estar ao mesmo tempo bem localizado } \\
\text { e espalhado? Dá pra ser ao mesmo tempo }\end{array}$ & $\begin{array}{l}\text { Reforça a conclusão } \\
\text { colocando o fator do } \\
\text { tempo e as } \\
\text { características dos } \\
\text { objetos físicos onda } \\
\text { e partícula. } \\
\text { Problematizando. }\end{array}$ & $\begin{array}{lrr}\text { Se a luz } & \text { está } \\
\text { espalhada } & \text { no } \\
\text { espaço } & \text { a } \\
\text { partícula } & \text { está } \\
\text { bem localizada, } \\
\text { algo pode estar } \\
\text { ao mesmo tempo }\end{array}$ & $\begin{array}{l}\text { Pergunta de } \\
\text { problematização }\end{array}$ & \\
\hline
\end{tabular}




\begin{tabular}{|l|l|l|l|l|}
\hline & as duas coisas? & & $\begin{array}{l}\text { espalhado e } \\
\text { localizado? }\end{array}$ & \\
\hline 193 & A61: Depende. & & $\begin{array}{l}\text { Levantamento } \\
\text { de } \\
\text { hipótese/ }\end{array}$ \\
\hline 194 & $\begin{array}{l}\text { Prof.: Dependicação } \\
\text { agora é isso aqui: interferência eu só } \\
\text { consigo explicar como onda, efeito } \\
\text { fotoelétrico, só consigo como partícula... }\end{array}$ & & & \\
195 & A62: A luz não poderia ser uma exceção? & & $\begin{array}{l}\text { Pergunta de } \\
\text { problematização }\end{array}$ & $\begin{array}{l}\text { Levantamento hipótese } \\
\text { de }\end{array}$ \\
\hline
\end{tabular}

Tabela 19: recorte entre os turnos 189 a 195 do momento 4 da aula 2

Por fim, após toda a discussão há a introdução da problemática maior da SEI sobre a natureza da luz. Isso pode ser visto no recorte a seguir.

No turno 189, aproveitando a sequencia de perguntas de sistematização que faz com que os alunos concluam sobre a não explicação dos fenômenos apresentados somente como onda ou somente como partícula, o professor faz uma pergunta de problematização: "Posso dizer que é os dois?" (T 189). Essa é uma situação nova que excede o conhecimento clássico sobre a luz. Os alunos respondem com levantamento de hipóteses. No turno 190, Teresa diz "Em determinada situação". No turno 191, mais uma hipótese, desta vez de Augusto: "É intermediário". Diante da situação nova e da problemática expressa pela pergunta, os alunos levantam hipóteses para tentar solucionála.

No turno 192, o professor relembra os alunos da característica de cada um dos modelos clássicos explicativos para luz, de que a luz como onda está espalhada no espaço e a partícula está bem localizada. Em seguida, o professor faz outra pergunta de problematização: "Onda tá espalhada, partícula tá localizada, certo? Começa por aí, algo pode estar ao mesmo tempo bem localizado e espalhado? Dá pra ser ao mesmo tempo as duas coisas?' (T 192). O restante das aulas terá esse norte. Esse é o problema central da SEI e foi colocado somente no final da aula. Depois de resumir e organizar as informações das discussões, o professor problematiza mais uma vez o foco da investigação e, assim como visto nos momentos anteriores, a pergunta de problematização é acompanhada por indicadores de levantamento de hipóteses e explicação. Porém, os alunos já têm elementos para saber que a luz tem, de fato, comportamentos diferentes em diferentes situações. Ao responder as perguntas do professor, embora não saibam explicar qual é então a natureza da luz, os alunos têm elementos para afirmar que serão diferentes, por isso dão respostas de levantamento de 
hipóteses e de explicações.

\subsubsection{Observações gerais acerca da aula 2}

A aula 2 é uma aula introdutória da SEI e apresenta um número grande de interações entre professor e alunos. O professor centraliza a discussão, realizando muitas perguntas para os alunos. Nessa aula, o professor retoma grande parte dos conceitos e experiências abordados anteriormente à sequência. Tal relação é marcada pela presença de perguntas de sistematização, com as quais se pergunta objetivamente o que é um conceito ou uma lei. Com essas perguntas, os alunos apresentam um grande número de indicadores de explicação.

São observadas também perguntas sobre dados, com as quais se retoma dados observados nas montagens clássicas, como a imagem das fendas e do efeito fotoelétrico - neste caso, dados para auxiliar os alunos a lembrarem dos fenômenos. Às perguntas de dados os alunos apresentam grande número de indicadores de previsão. Notamos também uma aparição de perguntas exploratórias sobre o processo relacionadas a situações onde são avaliados casos não evidentes e articulados conceitos estabelecidos com situações empíricas hipotéticas ou não.

Ao término da aula, ocorre a sistematização das conclusões e das incongruências dos modelos ondulatório e corpuscular. Com isso, é possível estabelecer o problema central da sequência: "Qual é a natureza da luz?" - que, na sua categoria, é uma pergunta de problematização. Os alunos seguirão durante a SEI investigando outros experimentos e simuladores em busca da resposta.

\subsection{Aula 10: Interpretações da Mecânica Quântica}

Como dissemos, a aula 10 (que também compreende a aula 11) é a última da SEI. Ou seja, entre a aula 2 e a aula 10, como podemos ver no anexo A, os alunos vão ao laboratório, manuseiam em grupos o interferômentro de Mach-Zehder (IMZ) para verificar 
os padrões de interferência e discutem os resultados. Vão também ao laboratório de informática para explorar o interferômetro virtual, no qual é possível reduzir a intensidade da luz emitida pela fonte até um fóton individual. E, por fim, discutem os procedimentos e conceitos relativos aos experimentos.

Os objetivos da aula 10 são apresentar as quatro interpretações para o comportamento do fóton no interferômetro de Mach-Zehnder e mostrar que nenhuma delas explica o comportamento do fóton individual de forma completamente satisfatória.

Os alunos estão dispostos em círculo, o professor retoma as discussões sobre a interferência no IMZ e problematiza sobre como explicar o fenômeno da interferência para um único fóton. Os alunos têm em mãos uma folha com a atividade que deverão fazer e entregar após a discussão para buscar entender a natureza da luz. Há uma apresentação em PowerPoint em que o professor mostrará as quatro linhas interpretativas da mecânica quântica para a natureza da luz (ondulatória, corpuscular, dualista-realisa e complementaridade). O professor promove um debate entre os alunos e, ao término, sistematiza a aula, salientando que nenhuma das interpretações é totalmente satisfatória para explicar completamente o comportamento do fóton no interferômetro. Em seguida, entrega as atividades finais aos alunos.

Essa aula tem 307 turnos, um número grande de interações entre professor e alunos devido ao debate promovido pelo professor (anexo C). Separamos a aula em 6 momentos principais: 1) introdução, lembrança do experimento do interferômetro e das figuras de interferência observadas; 2) exploração do fenômeno de interferência da experiência tanto para a luz quanto para o fótons individuais comparando as figuras formadas; 3) 0 problema da interferência para um único fóton no interferômetro; 4) as quatro interpretações da mecânica quântica para a natureza da luz; 5) as explicações das quatro interpretações para a interferência com apenas um fóton - nas quais o professor explora as interpretações junto com os alunos para ver como cada uma delas pode explicar a interferência de um fóton; e 6) sistematização das explicações das quatro linhas interpretativas para a interferência de um fóton.

A seguir, veremos com mais detalhes cada um desses momentos da aula.

Momento 1: Introdução da aula, lembrança do experimento do interferômetro e das figuras de interferência observadas 
O primeiro momento da aula vai do turno 1 ao turno 31 . Ela começa com uma fala do professor retomando o que foi visto nas últimas aulas, desde a aula 2 - em que o problema da natureza da luz foi colocado - e passando pela experiência com o interferômetro de Mach-Zehnder real e o simulador, as atividades e discussões. $\mathrm{O}$ professor distribui uma folha com as atividades a serem feitas após a discussão. Ele resume como será a aula, retomando conceitos e experiências de modo a tentar entender a luz. Com isso, começa a relembrar o experimento do IMZ, seus componentes e a função de cada um deles. Esse processo de introdução é importante para poder situar os alunos sobre quais assuntos serão tratados no decorrer da aula e quais conceitos serão demandados. Nessa introdução, o professor lança mão de algumas perguntas também.

Por parte do professor são seis perguntas, sendo cinco sobre dados e uma de problematização. O professor se volta para a explicação das franjas de interferência com a mudança de anteparo no experimento. No IMZ, conforme a imagem abaixo, quatro semiespelhos dividem a passagem da luz fazendo com que no anteparo se verifique um padrão de interferência (imagem 2). Os alunos manusearam o aparelho, obstruindo o caminho da luz em trechos e verificando a imagem formada.

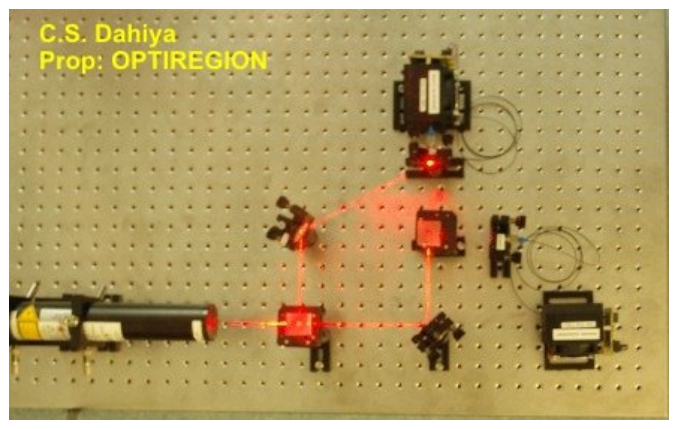

Imagem 1: representação do Interferômetro de Mach-Zehnder

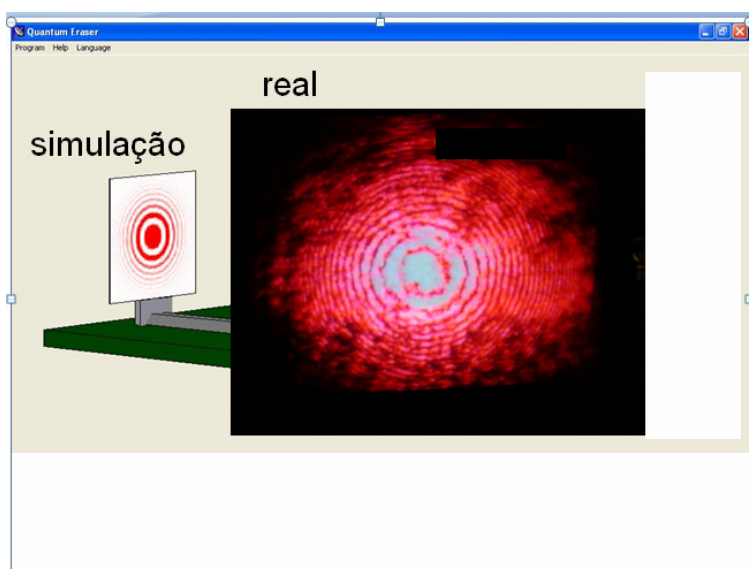

Imagem 2: figura de interferência formada no IMZ 
Os alunos apresentam cinco tipos de indicadores de alfabetização científica: cinco de organização de informações, quatro justificativas, três explicações, uma classificação e uma explicação com raciocínio lógico. Escolhemos um recorte para ilustrar a introdução da aula e as interações registradas.

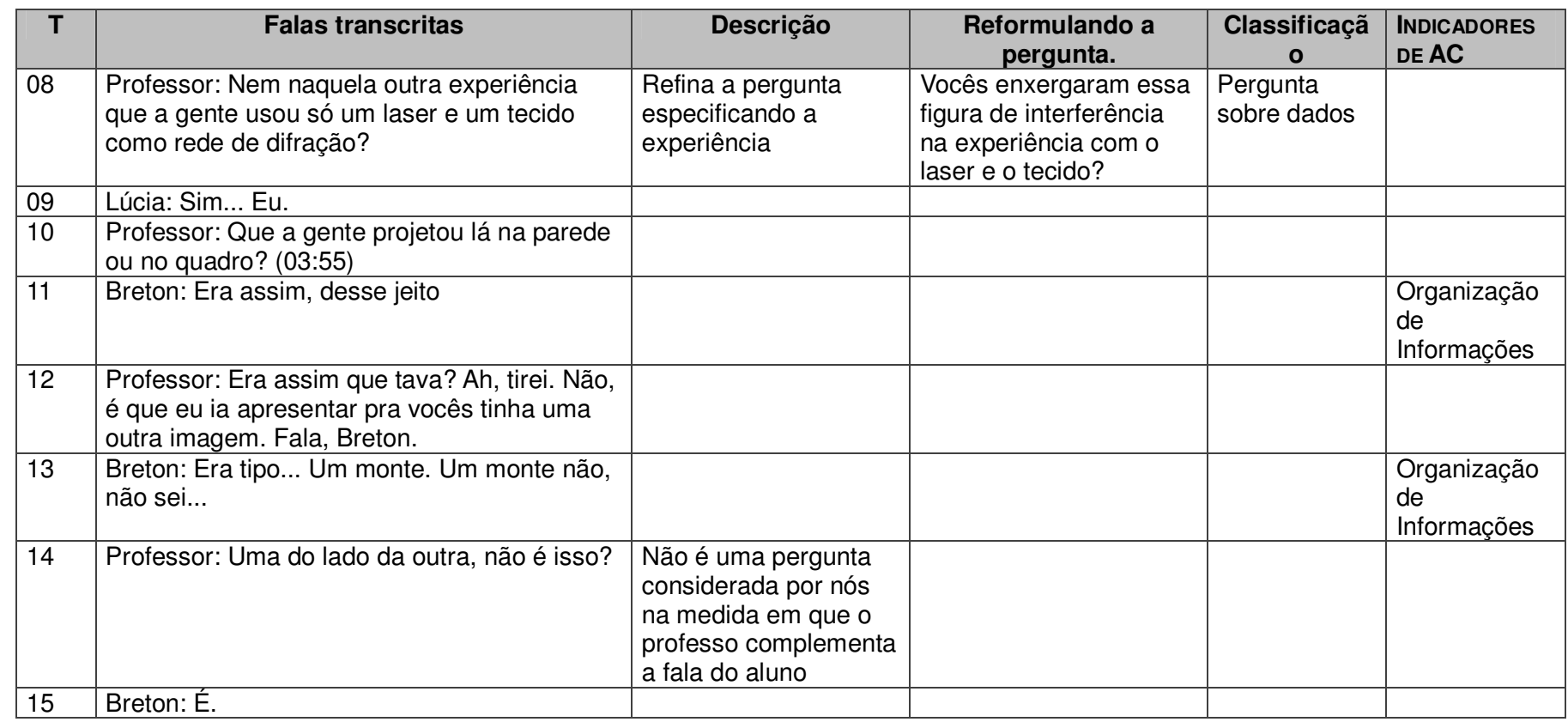

Tabela 20: recorte entre os turnos 8 a 15 do primeiro momento da aula 10.

No turno 8, após ter perguntado se os alunos haviam observado uma figura de interferência no IMZ real, o professor insiste e lança uma pergunta sobre os dados disponíveis na apresentação (imagem 2): "Vocês enxergaram essa figura de interferência na experiência com o laser e o tecido?" (T 9). O professor está retomando informações, conceitos e relações importantes para a discussão que ele pretende estabelecer com a sala. Em resposta, o aluno Breton confirma a semelhança da figura projetada com o observado na experiência: "era assim, desse jeito." ( $T$ 11). O professor confirma a intervenção de Breton (T12), este tenta esclarecer o que disse antes (T 13) e o professor o ajuda a organizar sua fala: "uma do lado da outra, não é isso?" (T 14) e ele responde

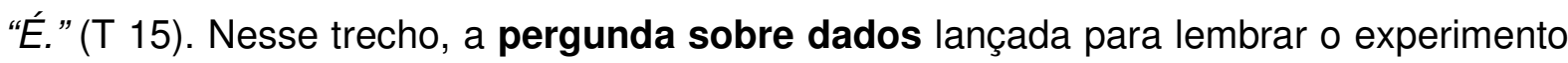


e o padrão de interferência visualizado faz com que o aluno apresente indicadores de organização de informações.

Até o final desse momento da aula, o professor busca lembrar os alunos dos dados observados durante as experiências realizadas ao longo da SEl. Lembrando, para cada passo, que tipo de figura ou mudança na obstrução da luz era observado. Os alunos vão organizando as informações da mesma forma que o recorte mostra. Após essas lembranças, o professor passa a explorar a experiência realizada considerando a interferência da luz contínua e de fótons individuais.

Momento 2: Exploração do fenômeno de interferência para o fótons individuais da experiência observada comparando as figuras formadas

O segundo momento da aula começa no turno 32, com o professor explicando e relembrando o que é a interferência, e vai até o turno 68, quando o professor passa a focar no problema da explicação do padrão de interferência para um fóton individual. Aqui, por meio de perguntas sobre dados, o professor vai lembrando os alunos do que acontecia quando interviam de alguma forma no experimento as figuras observadas na experiência tanto para a luz quanto para fótons individuais.

Ao todo, aparecem quatro perguntas do professor de acordo com a nossa categoria, sendo três sobre dados e uma exploratória sobre o processo. Os indicadores de alfabetização científica apresentados totalizam 16: a maior ocorrência é de indicadores de explicação (5) e, em seguida, vêm os de justificativa (4), de organização de informações (3), de raciocínio lógico (2), de classificação de informações (1) e de levantamento de hipóteses (1).

Separamos dois recortes para ilustrar as interações neste momento da aula. $O$ primeiro, do turno 40 ao 53, mostra como os alunos e o professor estão relembrando o experimento e comparando resultados, e o segundo (do turno 59 ao 68) ilustra a comparação das figuras observadas para o fóton individual.

\begin{tabular}{|c|c|c|c|c|c|}
\hline $\mathbf{T}$ & Falas transcritas & Descrição & $\begin{array}{l}\text { Reformuland } \\
\text { o a pergunta. }\end{array}$ & $\begin{array}{c}\text { Classificaçã } \\
0\end{array}$ & $\begin{array}{l}\text { INDICADORES DE } \\
\text { AC }\end{array}$ \\
\hline
\end{tabular}




\begin{tabular}{|c|c|c|c|c|c|}
\hline 040 & $\begin{array}{l}\text { Professor: É o mesmo, não é? O que ta acontecendo só } \\
\text { é que a gente aqui vai... Quando a gente manda com o } \\
\text { laser forma imagem instantaneamente, não é isso? Todo } \\
\text { o fóton... Ele vai se distribuindo, né? E dependendo da } \\
\text { quantidade que a gente tem aí a gente vai acabar } \\
\text { observando a linha, certo? Até aqui nenhuma novidade, } \\
\text { né? Tudo bem aí, Guilherme? Explica essas duas } \\
\text { figuras aí pra mim, por favor. Fala aí, Willian. }\end{array}$ & $\begin{array}{l}\text { O professor } \\
\text { relembra o } \\
\text { experimento e } \\
\text { chama a } \\
\text { atenção dos } \\
\text { alunos por } \\
\text { falarem. }\end{array}$ & & & \\
\hline 041 & Willian: O canto de lá é... & & & & $\begin{array}{l}\text { Organização } \\
\text { de } \\
\text { informações }\end{array}$ \\
\hline 042 & $\begin{array}{l}\text { Professor: O canto de lá você diz a direita de quem ta } \\
\text { olhando? }\end{array}$ & & & & \\
\hline 043 & Willian: Isso... Não, a esquerda de quem ta olhando. & & & & \\
\hline 044 & Alunos: Inaudível & & & & \\
\hline 045 & Professor: Vamos chamar esse de 1 e esse de 2. & & & & \\
\hline 046 & Willian: Ta. O 2 é de fóton e o de cá onda & & & & explicação \\
\hline 047 & Professor: O que eles têm de semelhante? & $\begin{array}{l}\text { Compara as } \\
\text { duas figuras de } \\
\text { interferência } \\
\text { com luz e } \\
\text { fotons }\end{array}$ & $\begin{array}{l}\text { Qual a } \\
\text { semelhança } \\
\text { entre os dois } \\
\text { resultados } \\
\text { (imagens)? }\end{array}$ & $\begin{array}{l}\text { Pergunta } \\
\text { sobre dados }\end{array}$ & \\
\hline 048 & Willian: O desenho... & & & & $\begin{array}{l}\text { Organização } \\
\text { de } \\
\text { informações }\end{array}$ \\
\hline 050 & Willian: é como se forma. & & & & $\begin{array}{l}\text { Organização de } \\
\text { informaões }\end{array}$ \\
\hline 051 & Professor: É o que? & & & & \\
\hline 052 & $\begin{array}{l}\text { Gilberto: Gradativamente, professor, conforme os fótons } \\
\text { vão chegando. (11:25) }\end{array}$ & & & & $\begin{array}{l}\text { Explicação / } \\
\text { raciocínio lógico }\end{array}$ \\
\hline 053 & $\begin{array}{l}\text { Professor: dessa maneira [aponta para uma das } \\
\text { imagens], a formação, ela é instantânea, né? E nessa } \\
\text { aqui [aponta a outra imagem] ele vai se formando } \\
\text { conforme vai acontecendo a chegada das partículas. }\end{array}$ & & & & \\
\hline
\end{tabular}

Tabela 21: recorte entre os turnos 40 a 53 do primeiro momento da aula 10.

No turno 40, o professor está falando do fóton e dos caminhos que ele pode tomar. Então, ao chamar a atenção de Guilherme, ele solicita que o aluno explique as figuras representadas na lousa. Nesse momento, o aluno Willian começa a esboçar uma explicação. Há uma confusão sobre a qual imagem Willian está se referindo. Até que, no turno 49, diante da tentativa de Willian de relacionar as imagens, o professor pergunta 0 que as imagens terão de diferente - uma pergunta sobre dados, levando em consideração a presença das imagens. Willian, diante da pergunta, organiza a informação primeiramente no turno 50: "É como se forma". O professor, buscando entender melhor o raciocínio de Willian, expressa dúvida e o aluno elabora uma explicação: "Gradativamente, professor, conforme os fótons vão chegando" (T 52). O professor valida a explicação de Willian sobre a maneira que a imagem de interferência é formada na interferência da luz. Observa-se instantaneamente o fenômeno, e com fótons individuais eles apresentarão o padrão de interferência depois de um tempo, quando muitos fótons tiverem chegado ao anteparo. 
Imediatamente após essa passagem, na qual se discute a formação do padrão de interferência para fótons disparados um a um, o professor passa para outros dois desenhos: um com a figura de interferência do interferômetro e outra sem interferência.

\begin{tabular}{|c|c|c|c|c|c|}
\hline $\mathbf{T}$ & Falas transcritas & Descrição & $\begin{array}{l}\text { Reformulando a } \\
\text { pergunta. }\end{array}$ & Classificação & $\begin{array}{l}\text { INDICADORES } \\
\text { DE AC }\end{array}$ \\
\hline 059 & $\begin{array}{l}\text { Professor: Qual a relação? Por que forma essa } \\
\text { figura aqui e não aqui? }\end{array}$ & $\begin{array}{l}\text { Explora a } \\
\text { comparação entre } \\
\text { a figura com e sem } \\
\text { interferência. }\end{array}$ & $\begin{array}{l}\text { Por que na } \\
\text { montagem } \\
\text { observamos esta } \\
\text { figura e não } \\
\text { esta? }\end{array}$ & $\begin{array}{l}\text { Pergunta } \\
\text { exploratória } \\
\text { sobre o } \\
\text { processo }\end{array}$ & \\
\hline 060 & Alice: Porque na primeira tem interferência. & & & & $\begin{array}{l}\text { Justificativa/ } \\
\text { Explicação }\end{array}$ \\
\hline 061 & Gilberto: Professor! & & & & \\
\hline 062 & $(12: 28)$ alunos: [inaudível] & & & & \\
\hline 063 & Professor: Fala, Gilberto! & & & & \\
\hline 064 & $\begin{array}{l}\text { Gilberto: Então, nos primeiros círculos as duas se } \\
\text { encontram, os dois raios estão juntos }\end{array}$ & & & & Explicação \\
\hline 065 & Professor: Pessoal! & & & & \\
\hline 066 & $\begin{array}{l}\text { Gilberto: Enquanto que na outra figura como tem } \\
\text { um detector ele impede a passagem de um dos } \\
\text { caminhos de chegar no anteparo, então só tem } \\
\text { um caminho que o fóton pode passar. Por isso, } \\
\text { ele não forma a figura. }\end{array}$ & & & & $\begin{array}{l}\text { Explicação/ } \\
\text { Justificativa } \\
\text { Rac. lógico }\end{array}$ \\
\hline 067 & $\begin{array}{l}\text { Professor: Tá. Então, nesse caso, não tem } \\
\text { interferência e aqui a gente tem interferência, não } \\
\text { é isso? Bom, agora o seguinte, o que a gente veio } \\
\text { conversando ao longo do ano inteirinho é que a } \\
\text { física pode explicar as coisas de duas maneiras, } \\
\text { ou como onda ou como partícula. }\end{array}$ & & & & \\
\hline 068 & Alice: A luz. & & & & \\
\hline
\end{tabular}

Tabela 22: recorte entre os turnos 59 a 68 do primeiro momento da aula 10.

Da mesma maneira que o recorte anterior, aqui, dentro do segundo momento da aula, fala-se sobre a interferência para um único fóton, elucidando as condições, a maneira de formação da imagem e o observado no laboratório de informática. Entretanto, a pergunta do turno 59 - "Por que na montagem observamos esta figura e não esta?" faz com que se tente estabelecer uma diferença conceitual entre as causas para os fenômenos representados nas duas figuras. Essa pergunta exploratória sobre o processo não apresenta uma resposta evidente, e faz com que os alunos tenham que relacionar fatos, ideias e conceitos já estabelecidos com os dados (imagens) disponíveis.

Diante disso, Alice, no turno 60, explica como se forma a figura, justificando sua ideia pelo fato de se tratar de dois fenômenos diferentes: "Porque na primeira tem interferência". Em seguida, Gilberto então oferece uma explicação para a interferência de ondas, no turno 64: "Então, nos primeiros círculos as duas se encontram, os dois raios estão juntos". O padrão apresenta a interferência destrutiva quando as ondas estão em fases diferentes e construtivas quando estão na mesma fase. O que Gilberto trouxe para 
a aula foi dizer, em outras palavras, que no centro da figura há interferência construtiva. Em seguida, Gilberto oferece uma explicação detalhada sobre o porquê de não se ter observado a figura de interferência quando se colocava o detector. No turno 66, ele diz: "Enquanto que na outra figura como tem um detector ele impede a passagem de um dos caminhos de chegar no anteparo, então só tem um caminho que o fóton pode passar. Por isso, ele não forma a figura". Nessa explicação do aluno, é possível identificar o indicador de raciocínio lógico. Sua fala expressa uma articulação que relaciona as situações e o fato de só haver um caminho para o fotón passar, portanto, considerando que o caráter de interferência da luz depende de duas frentes de onda, não é possível haver o padrão de interferência.

No recorte em questão, a pergunta exploratória sobre o processo abordou o porquê de haver ou não o padrão de interferência e levou os alunos a elaborarem justificativas e explicações.

Posta a condição experimental para haver ou não interferência no experimento, um novo momento da aula explorará os motivos para a interferência de um fóton único. Embora os alunos saibam, do próprio manuseio do IMZ, que a presença de um detector elimina o padrão de interferência, não sabem ainda como ele se forma se os fótons são lançados individualmente.

Momento 3: O problema da explicação para a interferência para um único fóton no interferômetro

O terceiro momento da aula vai do turno 69 até o turno 98. No turno 67, o professor havia concluído que a figura com franjas tinha interferência e que a outra figura, sem franjas, não tinha. Após isso, o professor introduz este novo momento da aula quando diz: "O que a gente veio conversando ao longo do ano inteirinho é que a Física pode explicar as coisas de duas maneiras, ou como onda ou como partícula". Neste caso, o problema da interpretação da interferência para fótons únicos será visto conforme esses dois modelos.

No total, são cinco perguntas do professor, sendo três de problematização e duas exploratórias sobre o processo. Por parte dos alunos, observamos oito indicadores de AC: quatro levantamentos de hipóteses, duas explicações, uma previsão e uma justificativa.

O recorte que selecionamos para ilustrar este momento compreende os turnos 75 ao 84 
e, nele, o professor discute a hipótese da natureza da luz que se divide em duas partes para causar interferência.

\begin{tabular}{|c|c|c|c|c|c|}
\hline $\mathbf{T}$ & Falas transcritas & Descrição & $\begin{array}{l}\text { Reformulando a } \\
\text { pergunta. }\end{array}$ & Classificação & $\begin{array}{l}\text { INDICADORES DE } \\
\text { AC }\end{array}$ \\
\hline 075 & $\begin{array}{l}\text { Professor: Mas duas partes do que? De } \\
\text { partícula? Duas partes de onda? Uma parte } \\
\text { partícula outra parte onda? }\end{array}$ & $\begin{array}{l}\text { Para hipótese do fóton } \\
\text { se dividir em duas } \\
\text { partes o professor } \\
\text { explora quais seriam } \\
\text { as partes desta } \\
\text { divisão. }\end{array}$ & $\begin{array}{l}\text { Se o fóton se } \\
\text { dividiu em duas } \\
\text { partes, o que } \\
\text { compõe essas } \\
\text { duas partes? } \\
\text { Partícula? Onda? } \\
\text { As duas coisas? }\end{array}$ & $\begin{array}{l}\text { Pergunta de } \\
\text { problematizaçã } \\
0\end{array}$ & \\
\hline 076 & Alice: Acho que as duas partes partícula. & & & & $\begin{array}{l}\text { Levantamento } \\
\text { de hipótese }\end{array}$ \\
\hline 077 & $\begin{array}{l}\text { Professor: Mas aí se ele se dividir ao meio, } \\
\text { eu deixo de ter um fóton e tenho dois. Dois } \\
\text { meio fótons... }\end{array}$ & & & & \\
\hline 078 & Alice: Aí depois eles se juntam. & & & & justificativa \\
\hline 079 & Professor: Junta aqui embaixo de novo? & $\begin{array}{l}\text { Professor testa a } \\
\text { hipótese da aluna. }\end{array}$ & $\begin{array}{l}\text { Após se dividir os } \\
\text { fótons se juntam } \\
\text { novamente? }\end{array}$ & $\begin{array}{l}\text { Exploratória de } \\
\text { processos }\end{array}$ & \\
\hline 080 & Alice: É, os dois lados. & & & & explicação \\
\hline 081 & $\begin{array}{l}\text { Professor: mas como é que com eles juntos } \\
\text { eu posso ter no anteparo dos dois lados? } \\
\text { Aqui... Olha, a Clara ta dizendo o seguinte, } \\
\text { aqui ele se divide, certo? Aí vem pra cá e } \\
\text { vem pra cá. Quando chega aqui, se eles se } \\
\text { juntam, como a Clara ta falando, eu teria } \\
\text { que ter observação em um único anteparo, } \\
\text { mas eu consigo medir nos dois ao mesmo } \\
\text { tempo. }\end{array}$ & $\begin{array}{l}\text { Motiva uma hipótese } \\
\text { para a explicação do } \\
\text { fóton se dividir e ser } \\
\text { medido nos dois } \\
\text { anteparos }\end{array}$ & $\begin{array}{l}\text { Se as duas } \\
\text { metades do fóton } \\
\text { se juntam como eu } \\
\text { posso ver nos dois } \\
\text { anteparos? }\end{array}$ & $\begin{array}{l}\text { Pergunta de } \\
\text { problematizaçã } \\
0\end{array}$ & \\
\hline 082 & $\begin{array}{l}\text { Márcia: (16:15) Eu estava pensando que ali } \\
\text { no meio eles se dividem de novo... }\end{array}$ & & & & $\begin{array}{l}\text { Levantamento } \\
\text { de hipótese }\end{array}$ \\
\hline 083 & Professor: Meninos, por favor! & & & & \\
\hline 084 & $\begin{array}{l}\text { Márcia: Vai passar uma parte ali e a outra } \\
\text { vai por ali, ó [aponta a figura] }\end{array}$ & & & & $\begin{array}{l}\text { Levantamento } \\
\text { de hipótese }\end{array}$ \\
\hline
\end{tabular}

Tabela 23: recorte entre os turnos 75 a 84 do terceiro momento da aula 10.

Nesse recorte, o professor aproveita a hipótese levantada por Alice diante do problema e pergunta, no turno 75: “O que compõem essas partes?”. A pergunta de problematização busca explorar a hipótese de Alice. Ela, ainda em suas hipóteses, no turno 76, diz que se dividiria em duas partes da mesma partícula. O professor faz um comentário, no turno 77, para testar a hipótese de Alice dizendo que se o fóton se dividir em dois deixará de ser um fóton - serão dois "meios fótons". Vale lembrar que não foi explicitado, nesse caso, que o fóton é uma partícula indivisível, por isso, o professor não recorre a tal definição, embora sua intervenção para testar a hipótese contenha essa premissa ao dizer que se dividir deixará de ser um inteiro, sendo dois meios.

Levando a hipótese de Alice adiante, o professor pergunta para toda a turma como seria essa divisão e a "reconciliação" do fóton no anteparo do experimento (T 81). Novamente, temos aqui uma pergunta de problematização e, nela, embutida a 
perspectiva e uma resposta com alguma hipótese de previsão. Isso fica evidente quando a aluna Márcia traz uma contribuição nos turnos 82 e 84: "Eu estava pensando que ali [semiespelho] no meio eles se dividem de novo" (T 82). "Vai passar uma parte ali e a outra vai por ali, ó [aponta a figura]" (T 84).

A problematização central proposta aqui envolve os procedimentos experimentais realizados pelos alunos com o interferômetro de Mach-Zehnder e o fato de que mesmo um fóton lançado por vez apresenta o padrão de interferência. Isso é um problema, pois a interferência explicada sob o ponto de vista ondulatório requer frentes de ondas simultâneas interagindo entre si para causar aquele padrão. Isso conflita com as condições ondulatórias para se ter interferências (frentes de onda interagindo), e a hipótese mais comum é a de que o fóton interfira com ele mesmo. Diante desse problema, as hipóteses são trazidas e o professor explica como seria a interferência considerando a hipótese de divisão do fóton em partes.

Após essa etapa e entendendo o problema da interferência para um único fóton, o professor recorre ao slide do PowerPoint para apresentar as quatro linhas interpretativas sobre a natureza da luz para a mecânica quântica (ondulatória, corpuscular, dualistarealista e da complementaridade). Ele anuncia que existem quatro interpretações para explicar a luz e os fenômenos relativos a ela, e a aula entra em um novo momento, para entender cada uma dessas linhas.

Momento 4: As quatro interpretações da mecânica quântica para a natureza da luz

O quarto momento da aula se estende do turno 99 até o turno 173. O professor faz 10 perguntas a serem analisadas neste momento da aula. São oito exploratórias sobre o processo e duas sobre dados. Os alunos, por sua vez, apresentam 29 indicadores de AC, sendo, em ordem de maior ocorrência, oito explicações, sete justificativas, sete levantamento de hipóteses, quatro construções com raciocínio lógico e trÊs classificações de informações.

Neste momento da aula, que ocupa a maior parte dela, o professor investiga, junto com os alunos, as quatro interpretações, construindo o significado para cada uma. Esse processo se dá, principalmente, por meio de perguntas em que se coloca o que aquela interpretação vai dizer sobre a luz. Tal exploração de ideias só é possível por conta do percurso que os alunos fizeram ao longo da SEI. Há mais discussão quando o professor 
explora as interpretações dualista-realista e da complementaridade, já que nas interpretações ondulatória e corpuscular os alunos já respondem prontamente que a luz é, para essas interpretações, onda e partícula, respectivamente.

Os recortes escolhidos para analisarmos aqui retratam bem o caráter da interação neste momento da aula em que o professor preponderantemente solicita aos alunos uma possível explicação sobre o que cada uma dessas interpretações dirá acerca da natureza da luz. A partir do turno 109, o professor discutirá com os alunos a interpretação dualistarealista. $\mathrm{Na}$ lista passada aos alunos, a complementaridade era a próxima a ser discutida. O professor então decide pular essa interpretação (talvez pelo fato de ela ser a mais aceita na comunidade científica) e perguntar sobre a dualista-realista

\begin{tabular}{|c|c|c|c|c|c|}
\hline $\mathbf{T}$ & Falas transcritas & Descrição & $\begin{array}{l}\text { Reformulando a } \\
\text { pergunta. }\end{array}$ & $\begin{array}{l}\text { Pergunta } \\
\text { do } \\
\text { professor }\end{array}$ & $\begin{array}{l}\text { INDICADORES DE } \\
\text { AC }\end{array}$ \\
\hline 109 & $\begin{array}{l}\text { Professor: São fótons. Fóton é uma } \\
\text { partícula de luz. Existe uma } \\
\text { interpretação... Vou pular pra ultima... } \\
\text { Dualista. }\end{array}$ & $\begin{array}{l}\text { Embora não haja } \\
\text { interrogação, esta é uma } \\
\text { pergunta implícita pela ação } \\
\text { anterior do professor em } \\
\text { perguntar o que pode ser } \\
\text { cada interpretação. Busca } \\
\text { dos alunos o que a } \\
\text { interpretação ondulatória. }\end{array}$ & $\begin{array}{l}\text { A interpretação } \\
\text { da luz chamada } \\
\text { dualista diz que a } \\
\text { luz é...? }\end{array}$ & $\begin{array}{l}\text { Pergunta } \\
\text { exploratória } \\
\text { de } \\
\text { processo. }\end{array}$ & \\
\hline 110 & $\begin{array}{l}\text { Márcia: Ora como onda e como } \\
\text { partícula. }\end{array}$ & & & & $\begin{array}{l}\text { Levantamento } \\
\text { de hipóteses }\end{array}$ \\
\hline 111 & Alice: Onda e partícula. & & & & $\begin{array}{l}\text { Levantamento } \\
\text { de hipóteses }\end{array}$ \\
\hline 112 & Gilberto: É onda e partícula? & & & & $\begin{array}{l}\text { Levantamento } \\
\text { de hipóteses }\end{array}$ \\
\hline 113 & $\begin{array}{l}\text { Professor: Que ela pode ser as duas } \\
\text { coisas ao mesmo tempo? É uma } \\
\text { partícula que é associada com uma } \\
\text { onda ou uma onda com uma partícula... }\end{array}$ & & & & \\
\hline 114 & Alunos: Inaudível. & & & & \\
\hline 115 & $\begin{array}{l}\text { Nicolau: 19:29 Você falou que não tem } \\
\text { como, que não pode ser onda e } \\
\text { partícula ao mesmo tempo }\end{array}$ & & & & $\begin{array}{l}\text { Justificativa/ } \\
\text { refutação }\end{array}$ \\
\hline 116 & $\begin{array}{l}\text { Professor: Então, aí cai nessa situação } \\
\text { que o Nicolau ta falando, né? }\end{array}$ & & & & \\
\hline 117 & Alice: ela é uma coisa e outra. & & & & explicação \\
\hline 118 & $\begin{array}{l}\text { Professor: É... Pra mecânica clássica } \\
\text { isso não é possível. }\end{array}$ & & & & \\
\hline 119 & Alice: Mas e em Quântica... & & & & justificativa \\
\hline 120 & Nicolau: Acho que é & & & & \\
\hline
\end{tabular}

Tabela 24: recorte entre os turnos 109 a 120 do quarto momento da aula 10.

A pergunta do professor que inicia esse recorte - "A interpretação da luz chamada dualista diz que a luz é...?" (T 109) - é uma pergunta exploratória de processo na medida em que os alunos não sabem o que a luz é para a interpretação em questão, mas têm elementos das discussões e do nome da interpretação (dualista-realista) para 
elaborar hipóteses ou explicá-la. Então surgem algumas hipóteses: no turno 110, a aluna Márcia diz "Ora como onda, ora como partícula"; no turno 111, a Alice diz "Onda e partícula" e Gilberto reforça com "É, onda e partícula". O professor então refina a hipótese de Gilberto e Alice dizendo ( $T$ 113) que a luz pode ser uma onda associada a uma partícula ou uma partícula associada a uma onda. Imediatamente, Nicolau (T 115) refuta a fala do professor justificando que, em aulas anteriores, o professor ter dito que não era possível ter onda e partícula ao mesmo tempo. O professor então explica (T 117) que, na mecânica clássica, não era possível, mas na Física moderna novas explicações têm que ser encontradas e uma delas pode ser a luz como as duas coisas ao mesmo tempo.

Após a confirmação de que a hipótese de Alice e Gilberto era procedente para a natureza da luz, o professor passa para a última interpretação, a da complementaridade. Neste outro recorte temos um percurso discursivo parecido.

\begin{tabular}{|c|c|c|c|c|c|}
\hline $\mathbf{T}$ & Falas transcritas & Descrição & $\begin{array}{c}\text { Reformulando a } \\
\text { pergunta. }\end{array}$ & $\begin{array}{l}\text { Pergunta do } \\
\text { professor }\end{array}$ & $\begin{array}{l}\text { INDICADORES DE } \\
\text { AC }\end{array}$ \\
\hline 123 & Professor: E complementaridade? & $\begin{array}{l}\text { Busca dos alunos o } \\
\text { que a interpretação } \\
\text { da } \\
\text { complementaridade }\end{array}$ & $\begin{array}{l}\text { A interpretação da luz } \\
\text { chamada } \\
\text { complementaridade, } \\
\text { deve dizer que a luz é } \\
\text { o quê? }\end{array}$ & $\begin{array}{l}\text { Pergunta } \\
\text { exploratória de } \\
\text { processo. }\end{array}$ & \\
\hline 124 & Nicolau: As duas se complementam & & & & $\begin{array}{l}\text { Levantamento } \\
\text { de hipóteses }\end{array}$ \\
\hline 125 & Márcia: uma completa a outra & & & & $\begin{array}{l}\text { Levantamento } \\
\text { de hipóteses }\end{array}$ \\
\hline 126 & Professor: Então, segundo a Alice... & & & & \\
\hline 127 & Nicolau: inaudível & & & & \\
\hline 128 & Márcia: Nicolau, para! & & & & \\
\hline 129 & $\begin{array}{l}\text { Professor: Não, mas essa ideia que o } \\
\text { Nicolau ta falando tem mais a ver com } \\
\text { a dualista, né? Num é? }\end{array}$ & & & & \\
\hline 130 & Nicolau: $\dot{E} \ldots$ & & & & \\
\hline 131 & $\begin{array}{l}\text { Gilberto: Professor, e se eu disser que } \\
\text { a luz é partícula... }\end{array}$ & $\begin{array}{l}\text { Começa a construir } \\
\text { a hipótese do turno } \\
133\end{array}$ & & & \\
\hline 132 & $\begin{array}{l}\text { Professor: Silêncio, eu não estou } \\
\text { ouvindo o Gilberto que tá quase do } \\
\text { meu lado. Fala, Gilberto. }\end{array}$ & & & & \\
\hline 133 & $\begin{array}{l}\text { Gilberto: E se eu falar que a luz é } \\
\text { partícula com fatores ondulatórios ou é } \\
\text { onda com fator de partícula? }\end{array}$ & & & \begin{tabular}{|l|} 
Pergunta de \\
problematização
\end{tabular} & $\begin{array}{l}\text { Elaboração de } \\
\text { hipóteses / } \\
\text { explicação }\end{array}$ \\
\hline 134 & $\begin{array}{l}\text { Professor: Aí nesse caso, você acha } \\
\text { que vai tá dentro de qual dessas } \\
\text { interpretações? }\end{array}$ & $\begin{array}{l}\text { Faz o aluno situar } \\
\text { sua descrição } \\
\text { dentro de uma das } \\
\text { interpretações da } \\
\text { mecânica quântica }\end{array}$ & $\begin{array}{l}\text { Qual interpretação } \\
\text { contempla o fato da } \\
\text { luz ser uma onda com } \\
\text { aspectos de partícula } \\
\text { ou partícula com } \\
\text { fatores ondulatórios? }\end{array}$ & $\begin{array}{l}\text { Pergunta } \\
\text { exploratória de } \\
\text { processo }\end{array}$ & \\
\hline 135 & $\begin{array}{l}\text { Gilberto: Então, mas assim, no meu } \\
\text { raciocínio ela segue um caminho, mas } \\
\text { só que o que complementa ela é o } \\
\text { outro. }\end{array}$ & & & & $\begin{array}{l}\text { Justificativa / } \\
\text { rac. lógico }\end{array}$ \\
\hline 136 & $\begin{array}{l}\text { Professor: Dá pra encaixar, não dá? } \\
\text { Dentro de uma dessas interpretações. } \\
\text { Fala aí, Cristina. }\end{array}$ & & & & \\
\hline
\end{tabular}


Tabela 25: recorte entre os turnos 123 a 136 do quarto momento da aula 10.

Como no caso anterior, da interpretação dualista-realista, neste caso, ao fazer a pergunta exploratória sobre o processo " $A$ interpretação da luz chamada complementaridade, deve dizer que a luz é o quê?" (T 123), o professor busca articular os conhecimentos dos alunos e o nome da interpretação para que ele apresentem hipóteses para o que possa ser a interpretação da complementaridade. No turno 124, Nicolau diz "as duas se complementam" e no turno 125 "uma complementa a outra”. Essas hipóteses estão mais relacionadas à interpretação dualista-realista, pois, para ela, a luz é uma partícula que carrega junto uma onda, ou seja, são as duas coisas ao mesmo tempo. E a interpretação da complementaridade expressa que dependendo da forma que se mede ou se observa a luz, ela poderá se comportar ora como partícula, ora como onda, não podendo ser as duas ao mesmo tempo.

O professor então associa a hipótese de Nicolau e Márcia à interpretação dualistarealista (T 129). Logo em seguida, no turno, 133, Gilberto lança uma nova hipótese: "E se eu falar que a luz é partícula com fatores ondulatórios ou é onda com fator de partícula?”. Essa pergunta poderia ser feita pelo professor, e se ele a fizesse, ela seria classificada como uma pergunta de problematização. O professor então devolve a pergunta: "Aí nesse caso, você acha que vai tá dentro de qual dessas interpretações?” (T 134). E Gilberto tenta justificar, no turno 135, dizendo que uma complementa a outra.

O momento de discussão sobre a complementaridade continua com a hipótese de Eduardo de que a complementaridade poderia ser um estado microscópico e um estado macroscópico da luz. Até que, no turno 150, a aluna Márcia argumenta contra Eduardo e expõe uma explicação "Porque aí ela tá sendo duas coisas ao mesmo tempo. Complementaridade é quando ela tá sendo ora uma coisa ora outra". Essa discussão se estende até o turno 173 sem uma definição ou validação do professor. No lugar disso, ele já muda o foco da discussão da possível explicação dessas linhas interpretativas para o fenômeno da interferência de um fóton único, o que significa um novo momento da aula.

Momento 5: As explicações das quatro interpretações para o padrão de interferência para apenas um único fóton

O quinto momento da aula vai do turno 174 até o 217. São oito perguntas que o 
professor faz, sendo sete exploratórias sobre o processo e uma de problematização. Oito também é o número de indicadores de alfabetização científica dos alunos: quatro explicações, uma classificação de informações, uma organização de informações, uma justificativa com raciocínio lógico.

Nesse momento da aula, o professor explora as quatro interpretações do comportamento da luz junto com os alunos para ver como cada uma delas pode explicar a interferência de um fóton. A pergunta "Como eu explico a interferência pela interpretação...?" é feita e refeita aos alunos para que eles discutam e relacionem o entendimento de cada interpretação a uma aplicação dos seus conhecimentos para explicar o no fenômeno do interferômetro.

Como o tipo de pergunta se repete para cada interpretação (para saber como ela explica o fenômeno da interferência), um recorte apenas pode ilustrar que tipo de interação predomina nesse momento da aula.

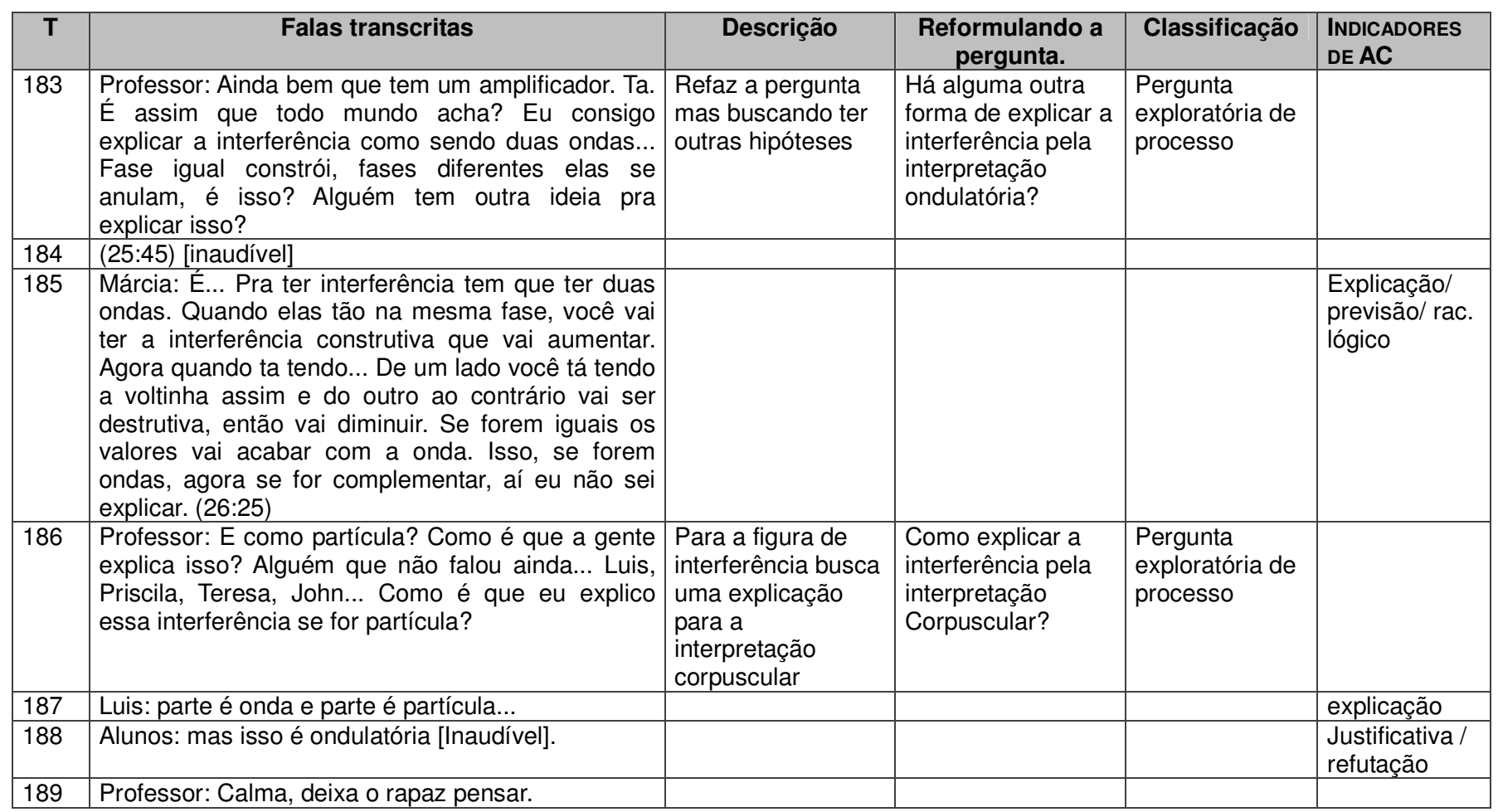

Tabela 26: recorte entre os turnos 183 a 189 do quinto momento da aula 10.

Conforme dissemos acima, as perguntas do professor no momento em questão buscam articular o entendimento recente das interpretações da mecânica quântica com o fenômeno da interferência, já trabalhado com os alunos ao longo da SEI. Esta é uma 
característica marcante das perguntas exploratórias sobre processo: articulação entre ideias e dados.

Nesse recorte, o professor pergunta, no turno 183, se há uma forma de explicar a interferência pela interpretação ondulatória da luz. A explicação correta considera a luz como uma onda e as frentes de onda se interferirão, formando padrões destrutivos e construtivos. Em resposta à pergunta do professor, no turno 185, a aluna Márcia desenvolve uma explicação: "É... Pra ter interferência tem que ter duas ondas. Quando elas tão na mesma fase, você vai ter a interferência construtiva que vai aumentar. Agora quando tá tendo... De um lado você tá tendo a voltinha assim e do outro ao contrário vai ser destrutiva, então vai diminuir. Se forem iguais os valores vai acabar com a onda. Isso, se forem ondas, agora se for complementar, aí eu não sei explicar". O professor passa para a próxima interpretação, considerando a explicação da aluna satisfatória. No mesmo turno 186, em que ele valida a explicação de Márcia, o professor já pergunta, aproveitando a linha de raciocínio traçada pela aluna, qual a explicação para a interpretação corpuscular.

Com as interpretações dualista-realista e da complementaridade, o professor também faz as mesmas perguntas para buscar a explicação da interferência para um único fóton, mas propositadamente não conclui nada sobre a explicação, pois essa será a tarefa individual de cada aluno após a discussão.

No entanto, a estrutura dessa discussão do quinto momento de aula segue a mesma: o professor perguntando como se pode explicar, os alunos elaborando hipóteses, buscando uma explicação e o professor fazendo falas de conclusão e sistematização. Por fim, no turno 217, o professor retorna às quatro interpretações descritas na folha de resumo e passa para um novo momento: o de ler e sistematizar o que trata cada uma.

Momento 6: sistematização as explicações das quatro linhas interpretativas para a interferência de um fóton e introdução da atividade

O sexto momento vai do turno 218 até o 292. O professor faz sete perguntas: quatro de sistematização e três exploratórias sobre o processo. Os alunos apresentam 25 indicadores de AC: 14 levantamento de hipóteses, seis explicações, três justificativas, uma organização de informações e uma classificação de informações.

Nesse momento da aula, o apoio do texto e a ação do professor caminham juntos para sistematizar as quatro interpretações para o comportamento da luz. O texto da 
atividade traz quatro frases, as quais os alunos têm relacionar a cada interpretação. $O$ professor busca, antes que os alunos resolvam a atividade, sistematizar as interpretações por meio de perguntas de sistematização do tipo: "Qual interpretação fala que a luz é... ?". O trecho recortado a seguir pode oferecer uma visão de como as discussões estão sendo desenvolvidas no momento em questão.

\begin{tabular}{|c|c|c|c|c|c|}
\hline $\mathbf{T}$ & Falas transcritas & Descrição & $\begin{array}{l}\text { Reformulando a } \\
\text { pergunta. }\end{array}$ & Classificação & $\begin{array}{l}\text { INDICADORES } \\
\text { DE AC }\end{array}$ \\
\hline 277 & $\begin{array}{l}\text { Professor: É... Qual delas fala sobre, né? Onda e } \\
\text { partícula juntas? }\end{array}$ & $\begin{array}{l}\text { Localizando a } \\
\text { interpretação com } \\
\text { a questão }\end{array}$ & $\begin{array}{l}\text { Qual interpretação } \\
\text { fala que a luz tem } \\
\text { duas partes? }\end{array}$ & $\begin{array}{l}\text { Pergunta de } \\
\text { sistematização. }\end{array}$ & \\
\hline 278 & Lúcia: Dualista. & & & & Explicação \\
\hline 279 & $\begin{array}{l}\text { Professor: } \dot{E} \text {, que ele fala que tem então uma } \\
\text { partícula surfando numa onda. Qual que fala } \\
\text { sobre isso? }\end{array}$ & Refaz a pergunta. & $\begin{array}{l}\text { Qual interpretação } \\
\text { fala que a luz tem } \\
\text { duas partes? }\end{array}$ & $\begin{array}{l}\text { Pergunta de } \\
\text { sistematização. }\end{array}$ & \\
\hline 280 & Alunos: Inaudível. & & & & \\
\hline 281 & Professor: Como é que é? A dois? & & & & \\
\hline 282 & Luis: A dois é complementaridade. & & & & Explicação \\
\hline 283 & $\begin{array}{l}\text { 41:41 Alunos: A três é ondulatória e a um é } \\
\text { dualidade }\end{array}$ & & & & Explicação \\
\hline 284 & $\begin{array}{l}\text { Professor: É isso? É isso, povo? Vamos conferir? } \\
\text { "Nunca um meio fóton foi detectado", ta certo? } \\
\text { Pensando na gente dividir a onda em duas partes, } \\
\text { ta certo? Na teoria corpuscular a gente não } \\
\text { consegue explicar então a gente precisa de uma } \\
\text { lógica nova, não é isso? Pensando como sendo } \\
\text { partícula, que ela é invisível esse tipo de coisa, } \\
\text { então eu preciso de uma nova lógica pra explicar } \\
\text { a partícula, pra explicar essa interferência, ta? Pra } \\
\text { um único fóton a gente não conseguiu dar } \\
\text { explicação. Onda vazia caminhando, né? Numa } \\
\text { partícula... A partícula caminhando nessa onda é } \\
\text { dualista realista. E esse aqui é complementar por } \\
\text { quê? Porque eu só vou ter informação da } \\
\text { natureza da luz depois de medir. Quando eu to } \\
\text { vendo a luz eu não sei se ela é onda ou se ela é } \\
\text { partícula. Se eu observo interferência eu to me } \\
\text { referindo a quê? }\end{array}$ & $\begin{array}{l}\text { Situar as } \\
\text { explicações/fenôm } \\
\text { enos dentro da } \\
\text { interpretação da } \\
\text { complementaridad } \\
\text { e }\end{array}$ & $\begin{array}{l}\text { Para a } \\
\text { complementaridad } \\
\text { e, quando } \\
\text { observamos um } \\
\text { fenômeno de } \\
\text { interferência a luz } \\
\text { será tratada como } \\
\text { o que? }\end{array}$ & $\begin{array}{l}\text { Pergunta de } \\
\text { sistematização }\end{array}$ & \\
\hline 285 & Alice: Onda. & & & & explicação \\
\hline 286 & $\begin{array}{l}\text { Professor: À onda. Se eu observo efeito } \\
\text { fotoelétrico? }\end{array}$ & $\begin{array}{l}\text { Situar as } \\
\text { explicações/fenôm } \\
\text { enos dentro da } \\
\text { interpretação da } \\
\text { complementaridad } \\
\text { e }\end{array}$ & $\begin{array}{l}\text { Para a } \\
\text { complementaridad } \\
\text { e, quando } \\
\text { observamos o } \\
\text { efeito fotoelétrico a } \\
\text { luz será tratada } \\
\text { como o que? }\end{array}$ & $\begin{array}{l}\text { Pergunta de } \\
\text { sistematização }\end{array}$ & \\
\hline 287 & Alice: Partícula. & & & & explicação \\
\hline
\end{tabular}

Tabela 27: recorte entre os turnos 277 a 287 do sexto momento da aula 10.

Com base no texto, as perguntas de sistematização têm o caráter de melhorar o entendimento e aperfeiçoar a explicação para cada uma das interpretações sobre o comportamento da luz. No turno 277, o professor pergunta "Qual interpretação fala que a luz tem duas partes?" e essa é uma pergunta de sistematização, para que os alunos localizem entre as linhas interpretativas que acabaram de discutir qual explica a natureza 
da luz daquela forma. No turno seguinte, a aluna Lúcia já responde com uma explicação: "dualista”. O professor então passa para a próxima pergunta de sistematização: "qual interpretação fala que a luz tem duas partes?" (T 279). A partir daí, os alunos começam a falar alto associando as interpretações às perguntas: o aluno Luis diz "A dois é complementaridade" (T 282). Essa resposta com indicadores de explicação será corrente nesta etapa de sistematização. O professor explica brevemente que eles terão que realizar uma atividade associando e explicando como cada interpretação descreve o comportamento a luz no interferômetro de Mach-Zenhder.

Após esses momentos, os alunos passam a resolver os exercícios e fazer perguntas burocráticas ao professor sobre notas, etc até o fim da aula.

\subsubsection{Observações gerais acerca da aula 10}

A aula 10 finaliza a SEI e congrega diversos elementos de sistematização e de exploração do processo investigativo. No primeiro momento da aula, o professor retoma grande parte dos conceitos e experiências abordados anteriormente. Há um grande número de perguntas sobre dados, na medida em que o professor deseja que eles lembrem as observações e as formas vistas durante o experimento realizado. Em correlação, observamos indicadores de organização de informações por parte dos alunos, nos quais eles vão lembrando e discutindo as figuras apresentas e obtidas nos experimentos.

Observamos, majoritariamente, nesse momento da aula, perguntas exploratórias sobre o processo, nas quais os alunos precisam articular o conhecimento e as informações obtidas até aquele momento da SEI para buscar uma resposta, seja para o levantamento de hipóteses sobre o que determinada interpretação diz sobre a natureza da luz, seja sobre como aquela interpretação explica a interferência para um único fóton. A grande maioria dos indicadores de AC observados foi de levantamento de hipótese um retrato da busca de resposta nas articulações entre os dados, as informações e as ideias.

Por fim, ao término da sequência, foram observadas algumas perguntas de sistematização para internalizar o que cada interpretação diz sobre o comportamento da luz. Para as perguntas de sistematização, observamos somente indicadores de alfabetização científica de explicação. 


\section{Síntese interpretativa das análises}

Ao longo das duas aulas analisadas com o foco nas perguntas feitas pelo professor e nos indicadores de alfabetização científica expressos pelos alunos, verificamos um número grande de perguntas associadas a indicadores nos diferentes momentos das aulas. São pares de perguntas-indicadores que devem ser analisados mais profundamente. Nosso intuito, explicitado pelas perguntas de pesquisa, é identificar os tipos de perguntas feitas pelo professor em uma aula investigativa de Física e também verificar como essas perguntas podem ajudar os alunos a desenvolver aspectos da alfabetização científica.

Para tanto, desenvolvemos, a priori, uma categoria de perguntas do professor baseada em nossos pressupostos teóricos. Os tipos de perguntas são: perguntas de problematização, perguntas sobre dados, perguntas exploratórias de processo e perguntas de sistematização. Nas duas aulas analisadas,,as perguntas aparecem da seguinte maneira, de acordo com os momentos de cada uma. 


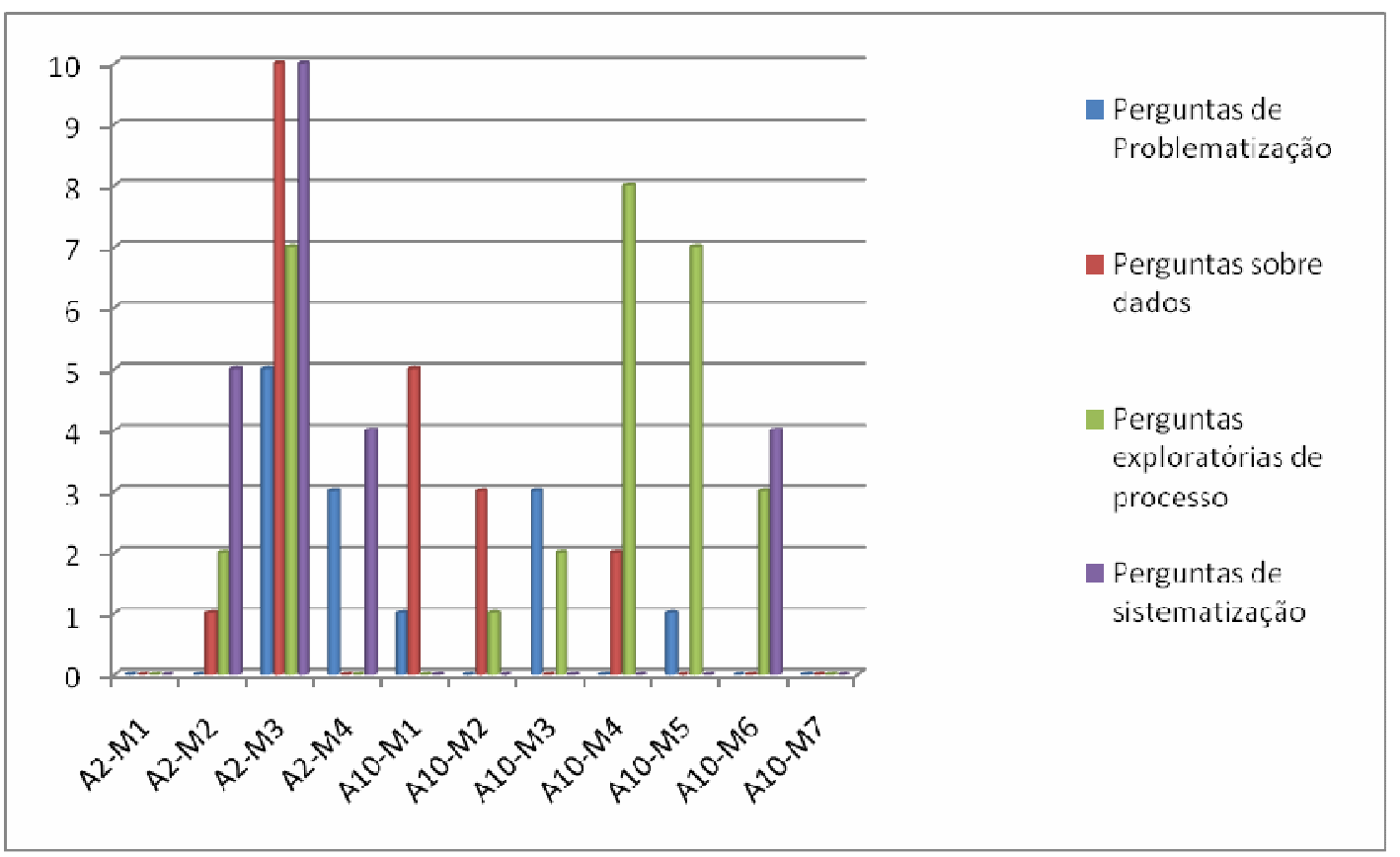

Gráfico 1- As perguntas do professor nos momentos das aulas - número absoluto

Os índices no eixo das abscissas são os momentos das aulas. A2-M1 deve ser lido como "aula 2 momento 1", e assim por diante. Na aula 2, início da SEI, há uma grande concentração de perguntas de sistematização e perguntas sobre dados. $\mathrm{Na}$ aula 10 , última aula da $\mathrm{SEl}$, observamos um grande número de perguntas exploratória sobre o processo, exatamente por se tratar de discussões que envolviam a articulação das ideias em torno dos conceitos novos, das observações e do experimento. Esta visão ampla do conjunto dos momentos, entretanto, pode não oferecer uma ideia mais precisa sobre as perguntas do professor e os indicadores de alfabetização científica dos alunos, na medida em que as perguntas do professor estão muito atreladas aos momentos da aula em que são postas e às intenções do professor naqueles momentos. Uma disposição percentual nos oferece novas possibilidades. 


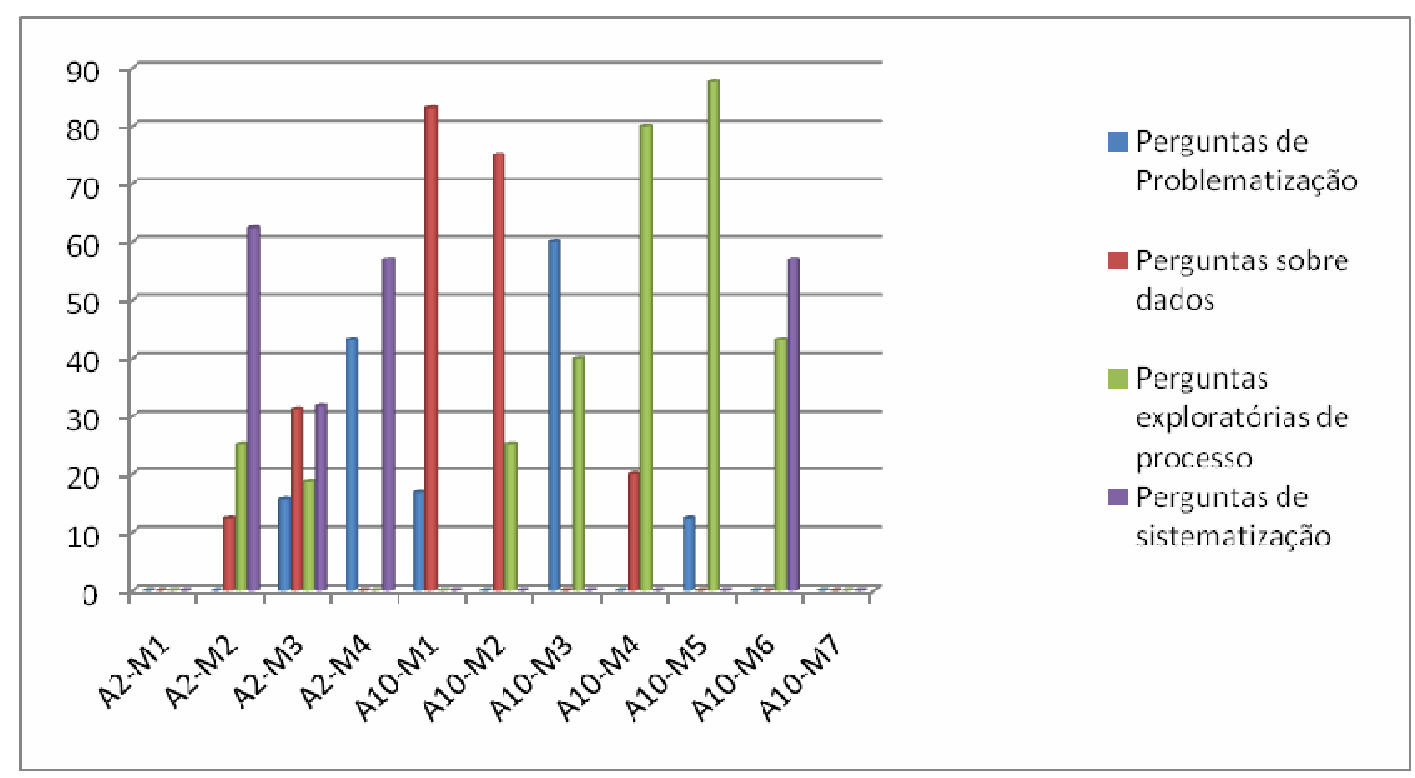

Gráfico 2: As perguntas do professor nos momentos das aulas - percentuais

Esse gráfico também nos faz perceber uma maior ocorrência percentual das perguntas de sistematização no início da sequência e de perguntas exploratórias sobre o processo na aula 10. Dentro de cada momento é que podemos verificar a importância da ação do professor na SEl quanto à realização de perguntas e também quanto às respostas dos alunos a essas perguntas.

Quando observamos atentamente as perguntas do professor e os indicadores de AC dos alunos, percebemos, ao longo dos momentos, que existem pares pergunta-indicador observados com maior frequência. $\mathrm{Na}$ apresentação das análises, mostramos quais são esses pares e em quais momentos eles ocorrem. Os quadros abaixo permitem resumir tais pares de acordo com os momentos de cada aula.

\begin{tabular}{|c|c|c|}
\hline \multicolumn{3}{|c|}{ Aula 2} \\
\hline $\mathbf{M}$ & Perguntas do professor & Indicadores de AC mais observados \\
\hline 1 & Nada verificado & Nada verificado \\
\hline 2 & Sistematização & Explicação e justificativa \\
\hline \multirow{5}{*}{3} & Sistematização & Explicação \\
\hline & Problematização & Levantamento de hipótese \\
\hline & Exploratórias do processo & levantamento de hipótese/ previsões \\
\hline & Sobre dados & Organização de informações \\
\hline & Sistematização & Explicação \\
\hline
\end{tabular}




\begin{tabular}{|l|l|l|}
\hline $\mathbf{4}$ & Problematização & Levantamento de hipótese \\
\hline
\end{tabular}

Tabela 27: pares perguntas/Indicadores mais frequentes nos momentos da aula 2.

\begin{tabular}{|c|c|c|}
\hline Aula 10 & & \\
\hline $\mathbf{M}$ & Perguntas do professor & Indicadores de AC mais observados \\
\hline $\mathbf{1}$ & Sobre dados & Organização de informações \\
\hline \multirow{2}{*}{$\mathbf{2}$} & Sobre dados & Organização de informações \\
\cline { 2 - 3 } & Exploratórias do processo & Explicação e justificativa \\
\hline \multirow{2}{*}{$\mathbf{3}$} & Problematização & Levantamento de hipótese \\
\cline { 2 - 3 } & Exploratórias do processo & Explicação e justificativa \\
\hline \multirow{2}{*}{$\mathbf{4}$} & Exploratórias do processo & Levantamento de hipótese/justificativa \\
\cline { 2 - 3 } & Exploratórias do processo & Levantamento de hipótese/ justificativa \\
\hline $\mathbf{5}$ & Exploratórias do processo & Explicação e justificativa \\
\hline $\mathbf{6}$ & Sistematização & Explicação e justificativa \\
\hline $\mathbf{7}$ & Nada verificado & Nada verificado \\
\hline
\end{tabular}

Tabela 28: pares perguntas/Indicadores mais frequentes nos momentos da aula 10.

Podemos perceber por essa tabela que, em diferentes momentos das aulas, podem aparecer perguntas do professor que provocam ou solicitam indicadores de alfabetização científica dos alunos. Essa relação causal pode ser interpretada com base em nosso referencial teórico. Uma pergunta contém em sua enunciação uma intenção que ocasionará alguns tipos de indicadores de AC nos alunos, como será explicitado no item seguinte do capítulo.

\subsection{As perguntas de problematização e os indicadores associados}

As perguntas de problematização foram verificadas em uma associação direta com indicadores de levantamento de hipóteses. Exemplos claros dessa relação foram demonstrados nos momentos destacados a seguir,

No terceiro momento da aula 2, o professor, após resumir a atividade e retomar conceitos, recoloca a pergunta que será levada adiante na investigação: "Afinal, a luz é o 
quê?" (T 62). Essa pergunta de problematização expõe o problema de investigação e, conforme vimos, um problema consiste de situações dificultosas, para as quais não existem soluções fechadas. Trata-se de uma situação, quantitativa ou não, que pede aos sujeitos envolvidos uma solução não evidente (GIL-PÉREZ et.al, 1992). Nessa perspectiva, uma pergunta de problematização oferece uma abertura às hipóteses para solucionar o problema. É o que verificamos na maioria das vezes em que uma pergunta de problematização é colocada.

Ainda na aula dois, ao término da aula, onde o problema de investigação é mais enfatizado, o professor pergunta "A luz pode ser o quê?" (T 172). Trata-se de uma pergunta de problematização caracterizando a dificuldade dos modelos clássicos em explicar a luz em todas as suas manifestações. Essa pergunta explicita o problema a ser investigado ao longo da sequência, e o reforça após todos os exemplos em que os modelos sobre a luz explicam cada qual um fenômeno. Em resposta a esse problema, o aluno Eduardo levanta uma hipótese "Onda com propriedades de partícula ou partícula com propriedades de onda." ( $T$ 173) e, logo em seguida. Eduardo levanta mais uma hipótese sobre o comportamento da luz: "Uma bolinha vibrando" (T 175). Após essas manifestações, o professor entrega um resumo das explicações para que os alunos possam discutir.

$\mathrm{Na}$ aula 10 , dentro do terceiro momento, outra pergunta de problematização (“Como eu explico o fenômeno da interferência para um único fóton?") também ocasiona indicadores de levantamento de hipóteses: "O fóton se divide em dois". Todos estão discutindo as explicações dos fenômenos observados no IMZ sob a perspectiva de um fóton lançado por vez. Trata-se de uma pergunta de problematização, pois a explicação para a interferência de um único fóton não foi oferecida, é um problema a ser resolvido e, diante disso, os alunos elaboram suas hipóteses.

O levantamento de hipóteses é uma etapa essencial para uma atividade de investigação, pois mobiliza os alunos a buscarem uma solução, criarem e imaginarem possibilidades que possam resolver o problema. Para a pergunta de problematização do professor, essa etapa é igualmente válida, no sentido em que a pergunta evidencia uma necessidade de buscar naquele momento - pela enunciação do professor - uma hipótese para resolver o problema.

\subsection{As Perguntas sobre dados e os indicadores associados}


Nas aulas analisadas, observamos uma associação direta entre as perguntas sobre dados do professor e indicadores de organização de informações.

$\mathrm{Na}$ aula 2, no momento em que o professor investiga algumas situações clássicas para discutir a natureza da luz e retoma o efeito fotoelétrico, ele faz perguntas sobre dados para relacionar grandezas verificadas no simulador de efeito fotoelétrico, estudado pelos alunos anteriormente. Conforme mostramos na análise, no turno 133 do momento 3 da aula 2, o professor pergunta: "O que observamos na simulação quando aumentamos a intensidade da luz?). Essa é uma pergunta sobre dados, pois relaciona as variáveis de um fato observado. Em resposta, o aluno afirma "Dependia da frequência da luž'. Ou seja, o professor, por meio da pergunta de dados, estava buscando uma organização de informações para reforçar variáveis daquele fenômeno. E a resposta do aluno organiza as informações, ressaltando a variável relevante.

No primeiro e segundo momentos da aula 10, a mesma observação pode ser feita. $O$ professor, fazendo o uso de imagens de interferência, pergunta à turma se eles observaram aquela imagem no experimento: "Foi esta figura de interferência que observamos quando fizemos o experimento?" (T 04). Associar a observação ao dado apresentado também é uma forma de organizar as informações e esclarecer o observado durante o experimento. Os alunos respondem que não observaram aquela figura, ou seja, descartam aquele dado do escopo a ser trabalhado. As perguntas sobre dados continuam na sequência daquele momento e, buscando esclarecer o que havia sido observado, os alunos vão organizando e classificando informações, de modo a considerar quais são os dados relevantes.

O tratamento com os dados tem uma função importantíssima dentro de uma investigação, pois é por meio do estudo e análise deles que a investigação ocorre. Ele é a ponte entre o fenômeno e sua possível lei, e traduz o observável em variáveis e proporções. Em uma atividade investigativa em que é possível desenvolver um problema específico, perguntas sobre os dados têm também o papel de chamar a atenção dos alunos para que eles possam perceber o que é ou não relevante na situação e de que forma aqueles dados se relacionam entre si. Essa percepção é o início de uma construção lógica buscada pela Física.

\subsection{As Perguntas exploratórias sobre processo e os indicadores associados}


As perguntas exploratórias apresentam algumas correlações importantes com os indicadores de alfabetização científica, principalmente com o de levantamento de hipóteses, o de justificativas e de explicações. Em sua essência, essa categoria envolve ideias dos estudantes, conceitos internalizados e evidências exteriores ou dados. É mais do que organizar informações, é organizar ideias. Os indicadores de levantamento de hipóteses nos remetem a à correlação das ideias e conceitos diante de um novo caso a ser respondido; já os indicadores de explicação e justificativa carregam a possibilidade de esta articulação levar o aluno a concluir ou explicar algo conforme suas concepções.

Quando o professor está investigando as situações clássicas para a luz, no terceiro momento da aula 2, ele pergunta, no turno 89: "Para uma pequena distância o que acontece com os efeitos da gravidade em uma partícula com a velocidade de $300.000 \mathrm{~km} / \mathrm{s}$ ?'. Essa pergunta envolve uma hipótese, uma situação hipotética em que os estudantes terão que articular seus conhecimentos prévios e conceitos internalizados para resolver a situação. Nessa etapa, observamos indicadores de levantamento de hipóteses. No turno seguinte, o aluno responde "Na cabeça dela", indicando que não se observará nenhuma queda da luz por conta da gravidade.

Na aula 10, quando a turma está discutindo as interpretações da mecânica quântica para a luz (momento 4), o tipo de pergunta característico que o professor faz é exploratória do processo. No turno 109, o professor pergunta aos alunos: "A interpretação da luz chamada dualista diz que a luz é...?”. Naquele momento da aula, sabemos que os alunos não tomaram conhecimento do que é a interpretação dualista-realista, por isso o intuito do professor é fazer com que eles articulem ideias e discutam o que pode ser essa interpretação. No turno seguinte, os alunos respondem: "Ora como onda e como partícula." (T 110) e "Onda e partícula." (T 112). Também observamos, nesse caso, indicadores de levantamento de hipóteses. No turno 143 da aula 10, quando a turma está discutindo sobre as interpretações, um aluno lança uma hipótese sobre a explicação da interpretação da complementaridade. Para ele, a luz poderia ser onda no "macro" e partícula no "micro". Diante disso, o professor tenta explorar as ideias dele sobre a hipótese: "A luz pode ser partícula no micro e onda no macro?". Essa é uma pergunta exploratória na medida em que busca a articulação de ideias do aluno, que responde a pergunta com uma explicação: "Depende de como se olha."

Articular ideias, criar situações e verificar hipóteses envolvem uma exploração mista do que é observado ou sabido com o que é novo ou problemático. Se os alunos desenvolvem uma hipótese, tendem a responder uma pergunta exploratória sobre o 
processo com justificativas e explicações. Se a pergunta vem relacionando uma articulação de ideias não evidentes, tendem a responder com levantamento de hipóteses. Em ambos os casos, portanto, lidamos com um processo de investigação, posterior à problematização e à elucidação dos dados: trata-se agora de uma articulação entre ideias e dados.

\subsection{As Perguntas de sistematização e os indicadores associados}

Em uma correlação muito clara, as perguntas de sistematização causam, na grande maioria das vezes, a expressão de indicadores de explicação pelos alunos. A pergunta de sistematização requer um conhecimento já obtido pelos alunos ou em processo de internalização. O que observamos nas duas aulas analisadas foi essa ocorrência em um número maior de vezes em dois momentos de cada aula.

No momento 2 da aula 2, no qual os alunos estão relembrando os conceitos de interferência e efeito fotoelétrico, muitas perguntas de sistematização aparecem exatamente para retomar informações, fenômenos e conceitos necessários ao desenvolvimento da aula. No turno 29 do segundo momento da aula 2 o professor faz uma pergunta de sistematização: “O que é o espectro discreto da luz?”. Em seguida, o aluno responde: "Quando você tem uma radiação que não tem todas as cores, aí você consegue ver quando passa de uma cor pra outra". Claramente, ele apresenta uma explicação para a pergunta feita. Essa pergunta, de sistematização, refere-se a conhecimentos anteriores à investigação e que serão necessários naquele momento ou durante toda a sequência.

Por outro lado, no final de toda discussão sobre a investigação, é necessária uma sistematização dos significados construídos ao longo da sequência. No momento 6 da aula 10, em que os alunos estão analisando as quatro interpretações, algumas perguntas de sistematização são feitas para que eles relacionem corretamente a interpretação com sua estrutura. No turno 277, o professor pergunta "Qual interpretação fala que a luz tem duas partes?". Para essa pergunta de sistematização, há possíveis quatro respostas, quatro interpretações para o comportamento da luz. Naquele momento da aula, ela tem a função de organizar e sistematizar o conhecimento construído. A aluna então responde com uma explicação: "Dualista”. Uma relação clara de sistematização e explicação caminhando juntas para fortalecer um conceito. 


\subsection{As perguntas dos alunos e suas contribuições na AC}

Uma observação que pudemos fazer nas análises das aulas - e para a qual não havíamos dispensado atenção inicialmente, por estarmos focados nas perguntas feitas pelo professor - trata das perguntas feitas pelos alunos. Nosso referencial teórico trata da pergunta como fenômeno discursivo, social e epistemológico, independente de quem a faça. Por outro lado, compreendendo o papel do professor no manejamento das interações discursivas em sala de aula, focamo-nos em construir uma categoria de tipos de perguntas em aulas investigativas para analisar como o professor pode influenciar no processo de alfabetização científica. Para analisar os alunos, utilizamos os indicadores de alfabetização científica desenvolvidos por Sasseron (2008). Porém, a interface entre essas duas vertentes de análise está posta exatamente quando os alunos atuam na discussão fazendo perguntas que, ao serem analisadas sob o ponto de vista das categorias por nós desenvolvidas, desempenham, tal qual as perguntas que o professor faz, um importante papel na construção dos significados para o coletivo da sala.

Paulo Freire, supracitado em nosso referencial teórico, ancorava-se muito na participação dos alunos em seu próprio processo de aprendizagem do mundo. Para ele, os problemas a serem discutidos em sala de aula para possibilitar novas construções devem ser trazidos pelos alunos do seio de sua vivência social. Segundo Freire, a curiosidade alimenta o conhecimento, mobiliza as pessoas para buscá-lo:

\footnotetext{
"A curiosidade do estudante às vezes pode abalar a certeza do professor. Por isso é que, ao limitar a curiosidade do aluno, a sua expressividade, o professor autoritário limita a sua também. Muitas vezes, por outro lado, a pergunta que o aluno, livre para fazê-la, faz sobre um tema, pode colocar ao professor um ângulo diferente, do qual the será possível aprofundar mais tarde uma reflexão mais crítica." (FREIRE, 1985, página 23)
}

Por outro lado, nosso outro referencial teórico de base, Bakhtin, nos oferece uma perspectiva dialógica das interações discursivas. A presença de várias vozes e discursos presentes na fala dialoga com a consciência do interlocutor. Mesmo que a fala externa não 
se manifeste, há dialogo no pensamento de quem ouve.

Quando um aluno faz uma pergunta prevista em nossas categorias como de problematização, sistematização, sobre dados ou exploratórias sobre o processo, estamos dizendo implicitamente que a pergunta é parte da cadeia enunciativa para a construção de significados.

Abaixo, destacamos as oportunidades em que as perguntas dos alunos tiveram esse papel nas duas aulas analisadas, mostrando o desenrolar nas interações com o professor e com a turma.

No segundo momento da aula 2, em que se retomam conceitos de interferência e de efeito fotoelétrico, quatro perguntas dos alunos exercem esse papel dialógico.

\begin{tabular}{|c|c|c|c|c|c|}
\hline $\mathbf{T}$ & Falas transcritas & Descrição & $\begin{array}{l}\text { Reformulando a } \\
\text { pergunta. }\end{array}$ & Classificação & $\begin{array}{l}\text { Indicadores } \\
\text { de AC }\end{array}$ \\
\hline 40 & Rubens: Professor... & & & & \\
\hline 41 & Prof.: Fala Rubens. & & & & \\
\hline 42 & $\begin{array}{l}\text { Rubens: Tem como descobrir se vai emitir ou não sem } \\
\text { fazer o teste? }\end{array}$ & $\begin{array}{l}\text { A pergunta do } \\
\text { aluno }\end{array}$ & $\begin{array}{l}\text { É possível descobrir } \\
\text { se há ou não } \\
\text { emissão de elétrons } \\
\text { sem verificar na } \\
\text { prática? }\end{array}$ & $\begin{array}{l}\text { Pergunta de } \\
\text { problematização }\end{array}$ & \\
\hline 43 & Prof.: Como assim? & & & & \\
\hline 44 & $\begin{array}{l}\text { Rubens: Tem alguma outra forma de saber se a luz vai } \\
\text { emitir ou não elétrons, antes de colocar a luz naquele } \\
\text { metal, tem como eu saber se vai emitir? }\end{array}$ & $\begin{array}{l}\text { Reformula a } \\
\text { pergunta }\end{array}$ & $\begin{array}{l}\text { É possível descobrir } \\
\text { se há ou não } \\
\text { emissão de elétrons } \\
\text { sem verificar na } \\
\text { prática? }\end{array}$ & \begin{tabular}{|l|} 
Pergunta de \\
problematização
\end{tabular} & \\
\hline 45 & $\begin{array}{l}\text { Prof.: Não. Pra você saber se é efeito fotoelétrico o que } \\
\text { você precisa saber, se o elétron vai ser arrancado de lá } \\
\text { quando incide luz, então o que você faz primeiro, você } \\
\text { mede pra ver se tá tendo emissão sem a luz, aí se tiver } \\
\text { emissão sem a luz não é efeito fotoelétrico, lembra que a } \\
\text { gente viu? São outras..Ãh? }\end{array}$ & & & & Explicação \\
\hline 46 & $\begin{array}{l}\text { Patrícia: Depois que sai o elétron do metal o que } \\
\text { acontece? }\end{array}$ & & $\begin{array}{l}\text { Após a emissão do } \\
\text { elétron o que } \\
\text { acontece com o } \\
\text { metal? }\end{array}$ & \begin{tabular}{|l|} 
Pergunta de \\
problematização
\end{tabular} & $\begin{array}{l}\text { Organização } \\
\text { de } \\
\text { informações. }\end{array}$ \\
\hline 47 & $\begin{array}{l}\text { Prof.: O que ele fez aqui? Que ele mostrou lá o } \\
\text { equipamento naquela simulação que tinha o Einstein } \\
\text { falando? Ele colocou um amperímetro ali e mediu a } \\
\text { passagem de corrente elétrica, não é isso? Então ele vai } \\
\text { verificar se tem ou não, aí ele até colocou uma situação, a } \\
\text { gente mediu alguma coisa com a fonte desligada por que? }\end{array}$ & $\begin{array}{l}\text { Retoma um } \\
\text { detalhe } \\
\text { experimental } \\
\text { da montagem }\end{array}$ & $\begin{array}{l}\text { No experimento } \\
\text { tivemos que medir a } \\
\text { corrente com a fonte } \\
\text { de luz desligada por } \\
\text { quê? }\end{array}$ & $\begin{array}{l}\text { Pergunta } \\
\text { exploratórias } \\
\text { sobre processo. }\end{array}$ & \\
\hline 48 & A18 (não identificado): Tinha luz ambiente. & & & & Explicação \\
\hline 50 & $\begin{array}{l}\text { Prof.: Tinha luz ambiente, então pra eu saber se é efeito } \\
\text { fotoelétrico ou não o que eu faço, deixo completamente } \\
\text { no escuro, sem incidência de luz nenhuma e verifico se } \\
\text { tem emissão ou não, se houver emissão essa emissão } \\
\text { não é devido ao efeito fotoelétrico. Tá? }\end{array}$ & & & & \\
\hline 51 & $\begin{array}{l}\text { Rubens: Antes de eu fazer o experimento, eu sei que } \\
\text { daqui a } 10 \text { min eu vou lá por o metal na luz, eu quero } \\
\text { saber antes de eu fazer isso tem como eu fazer um } \\
\text { cálculo ou algo do tipo, alguma coisa pra saber se quando } \\
\text { eu colocar vai emitir ou não? }\end{array}$ & $\begin{array}{l}\text { Aluno retoma } \\
\text { a pergunta }\end{array}$ & $\begin{array}{l}\text { É possível descobrir } \\
\text { se há ou não } \\
\text { emissão sem } \\
\text { verificar na prática? }\end{array}$ & $\begin{array}{l}\text { Pergunta de } \\
\text { problematização }\end{array}$ & \\
\hline 52 & $\begin{array}{l}\text { Prof.: Tem. O que vocês fizeram nos dois últimos } \\
\text { exercícios? Vocês fizeram os cálculos, pra calcular o que? }\end{array}$ & $\begin{array}{l}\text { Responde ao } \\
\text { aluno }\end{array}$ & $\begin{array}{l}\text { Nos exercícios, qual } \\
\text { era nosso objetivo } \\
\text { ao fazer os cálculos? }\end{array}$ & $\begin{array}{l}\text { Pergunta } \\
\text { exploratória de } \\
\text { processo }\end{array}$ & \\
\hline
\end{tabular}




\begin{tabular}{|c|c|c|c|c|c|}
\hline 53 & Cristina:A energia. & & & & explicação \\
\hline 54 & $\begin{array}{l}\text { Prof.: A energia necessária pra isso acontecer. Só? Saber } \\
\text { qual a energia necessária pra isso acontecer não é } \\
\text { suficiente? Oi? }\end{array}$ & & & & \\
\hline 55 & Patrícia: Pra que serve isso aí? & & $\begin{array}{l}\text { Para que serve o } \\
\text { efeito fotoelétrico? }\end{array}$ & $\begin{array}{l}\text { Pergunta de } \\
\text { sistematização }\end{array}$ & \\
\hline 56 & Prof.: Pra que serve o que? & $\begin{array}{l}\text { Busca } \\
\text { entender a } \\
\text { pergunta do } \\
\text { aluno }\end{array}$ & & & \\
\hline 57 & Patrícia: Aonde isso é usado? & $\begin{array}{l}\text { A aluna } \\
\text { deseja saber } \\
\text { uma } \\
\text { aplicação do } \\
\text { fenômeno. } \\
\end{array}$ & $\begin{array}{l}\text { Em que situações o } \\
\text { efeito fotoelétrico é } \\
\text { usado? }\end{array}$ & \begin{tabular}{|l|} 
Pergunta de \\
sistematização.
\end{tabular} & \\
\hline 58 & $\begin{array}{l}\text { Prof.: Ah... você quer um exemplo técnico de onde é } \\
\text { usado isso... fotocélula, pra acender a lâmpada a noite, } \\
\text { sensor de elevador. }\end{array}$ & & & & \\
\hline
\end{tabular}

Tabela 29: perguntas dos alunos no segundo momento da aula 2

Nesse recorte, duas dúvidas dos alunos são notadas. A primeira se refere a uma forma de saber teoricamente a emissão de elétrons ou não, e a segunda, a saber para que serve o efeito fotoelétrico, suas aplicações. É interessante notar que o professor utiliza outras perguntas para envolver os alunos na emergência da resposta.

Nos turnos 42, 44 e 51, o aluno pergunta e refaz a pergunta para o professor sobre a possibilidade de saber de antemão se o elétron sairia ou não da placa no efeito fotoelétrico. Essa pergunta é de problematização na medida em que se necessita aprofundar o conceito para respondê-la. A resposta do professor após a explicação da pergunta é falar da energia h.f $f^{4}$ de uma partícula, da qual os alunos tomaram conhecimento quando trabalharam com o efeito fotoelétrico. O professor envolve os alunos na lembrança dos dados e observações para poder responder à pergunta. E ele o faz com outra pergunta no turno 52: "Nos exercícios, qual era nosso objetivo ao fazer os cálculos?”, e o aluno responde: “Achar a energia” (T 53). Ou seja, a pergunta do aluno é problematizadora para ele e para a turma na medida em que não se tem uma resposta evidente. É preciso articular informações para chegar à resposta, e o professor o faz lembrando os alunos do que eles haviam feito e não respondendo prontamente à dúvida. Esse processo faz com que os alunos reflitam sobre as condições do fenômeno e o entendam melhor. Embora esteja retomando conceitos, esse problema poderia ser posto pelo professor como forma de retomar o antigo experimento do efeito fotoelétrico.

Ainda no mesmo momento da aula 2 , no turno 57, a aluna pergunta para 0

\footnotetext{
${ }^{4} E=h . f$, fórmula da energia quantizada
} 
professor onde aquilo (efeito fotoelétrico) pode ser utilizado. É uma pergunta clara de sistematização na medida em que aplica o conhecimento em situações do dia a dia. Em uma atividade investigativa, a abordagem de aplicação do conhecimento normalmente é feita após a reflexão e compreensão dos conceitos envolvidos. É uma forma de verificar se aquele conceito foi internalizado e também de dar mais sentido a ele. Nesse caso, a pergunta também serve para todos os alunos que estão ouvindo a aluna. Muitos poderiam tentar responder, aplicando o conhecimento deles sobre o efeito fotoelétrico ao dia a dia e, assim, trabalhando com a relação conceito-realidade. O professor responde prontamente citando células fotoelétricas e sensores de acender a iluminação pública.

As perguntas dos alunos na aula 2 apresentam um caráter mais propositivo, não são feitas em decorrência de uma pergunta do professor ou em resposta a alguma pergunta dele. São intervenções no decurso da discussão que demonstram curiosidade e engajamento dos alunos na atividade. Ao olharmos sob a perspectiva dos indicadores de $A C$, elas não se encaixam em algum específico; são dúvidas importantíssimas para o processo de ensino-aprendizagem, por colocarem o aluno na condição de "aceitar que não se sabe alguma coisa e, com essa atitude, mostrar que se quer saber, em vez de fingir que já se sabe.... é a ponte que nos põe em contato com o novo" (CORTELLA, 2008).

No quinto momento da aula 2, quando a turma está discutindo o problema do caráter dúbio da luz, dizendo que os modelos conhecidos não explicam perfeitamente todos os fenômenos da luz, um aluno faz uma pergunta:

\begin{tabular}{|c|c|c|c|c|c|}
\hline $\mathbf{T}$ & Falas transcritas & Descrição & $\begin{array}{l}\text { Reformulando a } \\
\text { pergunta. }\end{array}$ & Classificação & $\begin{array}{l}\text { Indicadores de } \\
\text { AC }\end{array}$ \\
\hline 192 & $\begin{array}{l}\text { Prof.: Uma terceira coisa? Lembrando } \\
\text { desde o inicio lá, nossa primeira } \\
\text { discussão sobre modelo, onda e partícula } \\
\text { são excludentes. Onda tá espalhada, } \\
\text { partícula ta localizada, certo? Começa por } \\
\text { aí, algo pode estar ao meso tempo bem } \\
\text { localizado e espalhado? Dá pra ser ao } \\
\text { mesmo tempo as duas coisas? }\end{array}$ & $\begin{array}{l}\text { Reforça a conclusão } \\
\text { colocando o fator do } \\
\text { tempo e as } \\
\text { características dos } \\
\text { objetos físicos onda e } \\
\text { partícula. } \\
\text { Problematizando. }\end{array}$ & $\begin{array}{l}\text { Se a luz está espalhada } \\
\text { no espaço e a partícula } \\
\text { está bem localizada, } \\
\text { algo pode estar ao } \\
\text { mesmo tempo } \\
\text { espalhado e localizado? }\end{array}$ & $\begin{array}{l}\text { Pergunta de } \\
\text { problematização }\end{array}$ & \\
\hline 193 & Patrícia: Depende. & & & & $\begin{array}{l}\text { Levantamento } \\
\text { de hipótese }\end{array}$ \\
\hline 194 & $\begin{array}{l}\text { Prof.: Depende né? O que a gente tem até } \\
\text { agora é isso aqui, interferência eu só } \\
\text { consigo explicar como onda, efeito } \\
\text { fotoelétrico só consigo como partícula... }\end{array}$ & & & & \\
\hline 195 & Gilberto: A luz não poderia ser uma & & & Pergunta de & Levantamento \\
\hline
\end{tabular}


O professor problematiza uma questão central da atividade investigativa sobre a incoerência entre os modelos corpusculares e ondulatórios: se pode haver algo ao mesmo tempo localizado e não localizado no espaço (como partículas e ondas, respectivamente). Como vimos em nossa análise, essa pergunta de problematização demanda o levantamento de hipóteses, e uma delas é colocada em forma de pergunta direcionada ao professor: "A luz não pode ser uma exceção?" (T 195). Ela revela uma articulação entre as contradições apresentadas durante a aula 2 para os modelos não explicarem todos os comportamentos da luz. É uma hipótese riquíssima do ponto de vista conceitual, pois, de fato, os objetos quânticos, como o fóton, se comportam de forma diferente. Essa hipótese lançada para a turma é também uma pergunta de problematização, pois expõe uma possível natureza distinta da luz. O propósito do professor é exatamente estudar essa natureza. Por isso, naquele momento da aula que inicia a investigação, ele responde introduzindo e validando o problema do aluno sem respondê-lo, já que a resposta será buscada ao longo da sequência.

Tomando pela ótica de nossas categorias, trata-se de uma pergunta de problematização, exatamente pelo fato de ser necessário uma série de experiências para poder entender melhor o comportamento da luz - experiências as quais os alunos tomariam contato naquela SEl. Ao mesmo tempo em que essa pergunta é problematizadora, é também uma hipótese sobre a natureza da luz, de que, talvez, a luz pudesse ter comportamentos duplos.

Considerando o conceito de dialogia expresso por Bakhtin (2000), podemos dizer que esta pergunta do aluno tem um papel duplo ao problematizar a questão perante os outros alunos que estão ouvindo aquele enunciado e ao levantar uma hipótese para o enunciador e para a turma. Em um processo de pensamento e fala interior, a pergunta problematiza, mas para o aluno é uma hipótese para a natureza da luz. Hipótese na qual outros poderiam ainda não ter pensado. Isso enriquece o escopo de possibilidades para 0 problema da natureza da luz.

$\mathrm{Na}$ aula 10, há outros momentos em que perguntas de problematização são feitas 
pelos alunos. Da mesma forma, neste caso, as perguntas dos alunos têm um papel duplo. Problematizam perante a sala e indicam levantamento de hipóteses por parte de quem pergunta.

No segundo momento dessa aula, quando discutem de que forma um fóton individual se comporta no interferômetro de Mach-Zehnder, o aluno Gilberto lança mais uma pergunta.

\begin{tabular}{|c|c|c|c|c|c|}
\hline $\mathbf{T}$ & Falas transcritas & Descrição & $\begin{array}{l}\text { Reformulando a } \\
\text { perqunta. }\end{array}$ & Classificação & $\begin{array}{l}\text { Indicadores de } \\
\text { AC }\end{array}$ \\
\hline 053 & $\begin{array}{l}\text { Professor: dessa maneira [aponta para uma das } \\
\text { imagens], a formação, ela é instantânea, né? E } \\
\text { nessa aqui [aponta a outra imagem] ele vai se } \\
\text { formando conforme vai acontecendo a chegada das } \\
\text { partículas. }\end{array}$ & & & & \\
\hline 054 & Gilberto: No laser os fótons estão todos juntinhos? & & & $\begin{array}{l}\text { Pergunta de } \\
\text { problematização }\end{array}$ & $\begin{array}{l}\text { Levantamento } \\
\text { de hipótese }\end{array}$ \\
\hline 055 & $\begin{array}{l}\text { Professor: Não, laser a gente tem que pensar na luz } \\
\text { sendo onda. Na verdade, ora como onda, ora como } \\
\text { partícula. Bom, e aqui? Alice S, compare essas duas } \\
\text { figuras. }\end{array}$ & & & & \\
\hline
\end{tabular}

Tabela 31: perguntas dos alunos no segundo momento da aula 10

Essa pergunta, da mesma forma que nos recortes anteriores com perguntas de alunos, demonstra uma articulação e entendimento do experimento no qual os fótons individualmente chegam para montar uma figura de interferência e uma especulação sobre a natureza da luz, ou seja, se a luz pode ser vista como partículas individuais, um lazer é um conjunto de fótons que podem estar todos juntos. Essa é, senão, a natureza quântica da luz. Novamente, a pergunta, feita diante dos colegas de turma, auscultadores, problematiza a natureza da luz e levanta uma hipótese sobre ela para o aluno. 0 processo de dialogia ocorre de forma intensa com o aluno que pergunta, dada a articulação entre o aprendido, o observado e a fala do professor, e também para os colegas, que se deparam com um novo problema e uma nova hipótese. O mesmo se observa no quarto momento da aula 10, quando discutem as quatro interpretações da mecânica quântica para a luz.

\begin{tabular}{|c|c|c|c|c|c|}
\hline $\mathbf{T}$ & Falas transcritas & Descrição & $\begin{array}{l}\text { Reformulando a } \\
\text { perqunta. }\end{array}$ & Classificação & $\begin{array}{l}\text { Indicadores de } \\
\text { AC }\end{array}$ \\
\hline 131 & $\begin{array}{l}\text { Gilberto: Professor, e se eu disser que a luz é } \\
\text { partícula... }\end{array}$ & & & & \\
\hline 132 & $\begin{array}{l}\text { Professor: Silêncio, eu não estou ouvindo o } \\
\text { Gilberto que ta quase do meu lado. Fala, } \\
\text { Gilberto. }\end{array}$ & & & & \\
\hline 133 & $\begin{array}{l}\text { Gilberto: E se eu falar que a luz é partícula } \\
\text { com fatores ondulatórios ou é onda com fator } \\
\text { de partícula? }\end{array}$ & & & $\begin{array}{l}\text { Pergunta de } \\
\text { problematização }\end{array}$ & $\begin{array}{l}\text { Elaboração de } \\
\text { hipóteses / } \\
\text { explicação }\end{array}$ \\
\hline
\end{tabular}




\begin{tabular}{|c|c|c|c|c|c|}
\hline 134 & $\begin{array}{l}\text { Professor: Aí nesse caso, você acha que vai } \\
\text { ta dentro de qual dessas interpretações? }\end{array}$ & $\begin{array}{l}\text { Faz o aluno situar } \\
\text { sua descrição } \\
\text { dentro de uma das } \\
\text { interpretações da } \\
\text { mecânica quântica }\end{array}$ & $\begin{array}{l}\text { Qual interpretação } \\
\text { contempla o fato da luz } \\
\text { ser uma onda com } \\
\text { aspectos de partícula ou } \\
\text { partícula com fatores } \\
\text { ondulatórios? }\end{array}$ & $\begin{array}{l}\text { Pergunta } \\
\text { exploratória de } \\
\text { processo }\end{array}$ & \\
\hline 135 & $\begin{array}{l}\text { Gilberto: Então, mas assim, no meu raciocínio } \\
\text { ela segue um caminho, mas só que o que } \\
\text { complementa ela é o outro. }\end{array}$ & & & & $\begin{array}{l}\text { Justificativa / } \\
\text { rac. lógico }\end{array}$ \\
\hline 136 & $\begin{array}{l}\text { Professor: Dá pra encaixar, não dá? Dentro } \\
\text { de uma dessas interpretações. Fala aí, } \\
\text { Cristina. }\end{array}$ & & & & \\
\hline
\end{tabular}

Tabela 32: perguntas dos alunos no quarto momento da aula 10

O aluno lança uma pergunta de problematização que é, ao mesmo tempo, uma hipótese sobre a natureza da luz. Nesse momento da sequência, essas questões estão sendo discutidas e esclarecidas, portanto, as hipóteses estão mais elaboradas. Do mesmo modo que problematiza, cria uma possibilidade para a natureza da luz. O professor novamente não responde diretamente, mas faz com que os alunos olhem para as linhas interpretativas para encaixar aquela hipótese dentro de uma descrição das interpretações da mecânica quântica para a natureza da luz.

No sexto momento da aula 10, quando discutem as explicações das quatro interpretações da mecânica quântica para a interferência com apenas um fóton, Alice faz uma pergunta.

\begin{tabular}{|c|c|c|c|c|c|}
\hline $\mathbf{T}$ & Falas transcritas & Descrição & $\begin{array}{l}\text { Reformulando a } \\
\text { pergunta. }\end{array}$ & Classificação & $\begin{array}{l}\text { Indicadores de } \\
\text { AC }\end{array}$ \\
\hline 219 & $\begin{array}{l}\text { Professor: O fóton como sendo uma onda, } \\
\text { certo? O fóton é uma onda e aí você tem o } \\
\text { quê? Você divide ao meio no primeiro } \\
\text { semiespelho, quando ele chega no segundo } \\
\text { semiespelho ele se junta novamente e aí a } \\
\text { gente tem a interferência. Agora, na segunda } \\
\text { interpretação o fóton é uma partícula e aí ela } \\
\text { não se divide nunca, ta certo? }\end{array}$ & & & & \\
\hline 220 & Alice: Por que uma partícula não se divide? & $\begin{array}{l}\text { Aluna questiona o } \\
\text { princípio da indivisibiliade } \\
\text { das partículas } \\
\text { fundamentais }\end{array}$ & & $\begin{array}{l}\text { Pergunta de } \\
\text { problematização }\end{array}$ & $\begin{array}{l}\text { Levantamento } \\
\text { de hipótese }\end{array}$ \\
\hline 221 & $\begin{array}{l}\text { Professor: Não. É a menor porção que a } \\
\text { gente pode ter. E aí neste caso, para um } \\
\text { único fóton... Ah... Como é que eu vou } \\
\text { explicar a interferência? }\end{array}$ & $\begin{array}{l}\text { Professor reforça o } \\
\text { princípio. Para a figura de } \\
\text { interferência busca uma } \\
\text { explicação para a } \\
\text { ondulatória visualizando } \\
\text { um único foton }\end{array}$ & $\begin{array}{l}\text { Como explicar a } \\
\text { interferência em } \\
\text { um único foton } \\
\text { pela } \\
\text { interpretação } \\
\text { ondulatória? }\end{array}$ & $\begin{array}{l}\text { Pergunta } \\
\text { exploratória de } \\
\text { processo }\end{array}$ & \\
\hline 222 & $\begin{array}{l}\text { Gilberto: Um único fóton é uma única } \\
\text { partícula... }\end{array}$ & & & & $\begin{array}{l}\text { Classificação/ } \\
\text { organização }\end{array}$ \\
\hline
\end{tabular}

Tabela 33: perguntas dos alunos no sexto momento da aula 10 
Essa última pergunta é extremamente problematizadora na medida em que sua exploração remonta a problemas da Física atual, dos modelos utilizados. Normalmente, não se discute o porquê das partículas fundamentais serem fundamentais. $E$ há teorias de que talvez elas não sejam. Portanto, uma pergunta com essa natureza certamente causa a quem ouve e está, naquele momento da aula, debruçado sobre a natureza da luz, uma problematização.

\section{Considerações finais}

Ao longo deste trabalho, intentamos responder às seguintes perguntas de pesquisa: "Quais os tipos de perguntas feitas pelo professor em uma aula de Física em que os alunos resolvem um problema?" e "Que tipo de contribuição as perguntas podem trazer para um ensino que vise a AC?'. Para tal, elaboramos, em consonância com nosso referencial teórico sobre as interações discursivas e o ensino de Ciências, uma categoria para classificar os tipos de perguntas que o professor faz em uma aula investigativa de 
Física. Utilizamos também os indicadores de alfabetização científica (SASSERON, 2008) para verificar quais deles ocorrem no decurso das falas dos alunos na interação com o professor e com os colegas.

Em nossa análise, classificamos e verificamos os padrões das perguntas do professor em aulas investigativas em que há um número grande de interações discursivas, e verificamos, concomitantemente, quais indicadores de alfabetização científica os alunos apresentam em seus discursos no decorrer da interação. Nossa análise está circunscrita a uma sequência sobre dualidade onda-partícula (BROKINGTON, 2005) utilizando os dados oriundos da pesquisa de mestrado de Barrelo Jr. (2010).

Observamos que há uma relação íntima entre as perguntas do professor e os indicadores de AC associados em determinados momentos das aulas. Essa relação expressa a pergunta como uma enunciação (BAKHTIN, 2000), com a característica de requerer do interlocutor uma expressão de resposta. Definimos a pergunta em nosso trabalho como um instrumento dialógico de estímulo à cadeia enunciativa responsiva, sendo assim usado com propósito didático dentro da estória da sala de aula, para traçar e acompanhar a construção de um significado e um conceito. Essa definição orientou nossa análise na medida em que percebemos o estímulo à cadeia enunciativa (BAKHTIN, 2000), com o qual os alunos se envolvem dialogando intensamente com o conjunto da sala de aula na busca por soluções, conceitos e investigações a cerca da dualidade ondapartícula e suas interpretações. Tal envolvimento dos estudantes também pôde ser identificado por meio dos indicadores de alfabetização científica apresentados por eles no decorrer das discussões. Assim, a relação entre a pergunta do professor e os indicadores de $A C$ dos alunos se configurou em pares pergunta-indicador.

Os pares mais observados em nossas análises foram:

Perguntas de problematização / levantamento de hipóteses - conforme ressaltamos, a atividade investigativa requer um problema a ser apreciado, buscado e discutido. Um problema pressupõe uma situação na qual não há respostas evidentes para resolvê-la (GIL-PÉREZ et al) e, portanto, o que se faz primeiro na investigação científica, diante de uma situação problema, é o levantamento de hipóteses. E, do mesmo modo, observamos o levantamento de hipóteses na atividade investigativa analisada.

Perguntas sobre dados / organização de informações - Em uma atividade investigativa, as variáveis relevantes ao fenômeno são discutidas com o grupo de alunos, 
que busca uma resposta ao problema. É notória na investigação a relação entre os dados disponíveis para a atividade e a organização das informações para considerar variáveis relevantes e descartar dados. Ao fazer esse tipo de pergunta, o professor explicita a necessidade de considerar ou levar os alunos a refletir sobre quais seriam os dados importantes a serem considerados na atividade investigativa. Por sua vez, os alunos organizam as informações disponíveis de forma a eliminar as variáveis irrelevantes e considerar as relevantes para compreender o fenômeno.

Perguntas exploratórias sobre o processo / levantamento de hipótese e Perguntas exploratórias sobre o processo/explicações e justificativa - após lidar com os dados e suas relações causais, relacionar ideias a fatos é um processo de exploração dos fenômenos estudados. Tal relação pode conter hipóteses sobre a forma como o conceito se aplica ou se comporta diante de uma situação, ou conter explicações oriundas dessa articulação de ideias tendo em vista e relação já estabelecida com os dados e os fenômenos.

Perguntas de sistematização / explicações e justificativas - no processo de investigação, são necessários muitas vezes o levantamento dos saberes prévios dos alunos e seus conhecimentos anteriores sobre determinado conceito, assim como alguns conceitos mais fundamentais, para que o problema proposto possa ser considerado pelos alunos como um problema de fato. Nessa etapa, anterior à proposição do problema, saber pontualmente se os alunos dominam os conceitos prévios envolve perguntas de sistematização e, na grande maioria das vezes, explicações e justificativas são dadas diante de um conceito já internalizado. Em nossa análise, no início da sequência, o professor pergunta sobre a reflexão (fenômeno já visto e discutido pelo grupo) e, em resposta, os alunos explicam e justificam o que é esse fenômeno. Por outro lado, ao término de uma SEI, pretende-se que os alunos tenham aprendido um determinado conceito, relacionando-o com a realidade social em que vivem (aspectos centrais da alfabetização científica). Neste momento da aula, as perguntas de sistematização buscam uma explicação do aluno sobre o conceito recém-construído e suas relações. As respostas a ela são também explicações e justificativas.

Não existem somente essas relações de pares em uma atividade investigativa. Porém, os pares destacados de nossa análise apresentam coerência com o que entendemos como atividade investigativa e com a construção da nossa categoria de 
perguntas feitas pelo professor. Verificamos, portanto, uma relação íntima entre as perguntas do professor e os indicadores de AC dos alunos nas aulas investigativas.

Diante de tais considerações, devemos nos voltar às perguntas de pesquisa para Ihes conferir a resposta que nosso trabalho de pesquisa construiu.

7.1 Quais os tipos de perguntas feitas pelo professor em uma aula de Física em que os alunos resolvem um problema?

A categorização dos tipos de perguntas foi elaborada teoricamente por nós e se constitui de perguntas de problematização, perguntas sobre dados, perguntas exploratórias sobre processo e perguntas de sistematização. Cada uma tem uma descrição apresentada na tabela 10 (página 42). Essas perguntas seguem nossos pressupostos teóricos sobre a alfabetização científica, as interações discursivas, a construção coletiva dos significados e as atividades investigativas problematizadoras.

Nossa análise mostrou que essa categorização é amplamente verificada nas aulas investigadas, nas quais os alunos estão resolvendo um problema. Tal ocorrência nos permite responder uma das perguntas de pesquisa considerando nossas categorias como válidas para nossos propósitos na pesquisa.

\subsection{Que tipo de contribuição as perguntas podem trazer para um ensino que vise à AC?}

Nossa análise apontou uma relação entre as perguntas do professor e os indicadores de alfabetização científica dos alunos. Essa relação expressa uma influência das perguntas e seus diferentes tipos no processo de construção de argumentos pelos alunos em sala de aula e, consequentemente, nos indicadores de alfabetização científica observados. Embora não consigamos responder precisamente o tipo de contribuição que as perguntas podem trazer para um ensino que vise à $A C$, sabemos que há contribuição na forma como se pergunta, sabendo, de antemão, que determinada pergunta requererá dos alunos, pelo seu caráter dialógico e intenção do professor no momento da aula, um tipo de raciocínio circunscrito ao contexto da pergunta. Ou seja, em uma aula onde as perguntas são postas obedecendo ao desenvolvimento da turma no curso da investigação, estas contribuirão para a alfabetização científica dos alunos. A fala do professor dialoga com os alunos e estes respondem ao estímulo com aspectos relacionados à alfabetização científica, como a argumentação, a compreensão básica de termos e conceitos científicos, e as relações entre Ciência e Tecnologia. 


\section{Conclusões}

As considerações finais de nosso trabalho já servem como conclusões da pesquisa proposta e das respostas às perguntas motivadoras deste trabalho de investigação. Podemos, diante do trabalho realizado e das considerações postas até agora, concluir, para finalizar a pesquisa desenvolvida, que a relação entre as perguntas do professor e os indicadores de alfabetização científica dos alunos existe e é profícua para ser 
explorada em sala de aula. Concluímos também que não só a pergunta do professor desenvolve esse papel; muitas vezes as perguntas que os alunos colocam durante a discussão exercem uma função semelhante àquela esperada por nós no início do trabalho em relação ao professor. Tal observação nos indica não só um processo de construção compartilhada e coletiva do conhecimento, como também um engajamento dos alunos em uma aula dialógica, colaborando e expressando dúvidas acerca de seus entendimentos. Essas dúvidas são, ao mesmo tempo, reconhecidas pelo restante da turma em um processo de dialogia e responsividade (Bakhtin, 2000). Isso nos faz supor que, quanto maior a participação dos alunos por meio de perguntas (dúvidas), mais rica do ponto de vista dialógico e de construção de significado será uma aula investigativa. Hipótese baseada em nossas observações, e profícua para futuras investigações.

\section{Referências Bibliográficas}

Amaral, E. M. R.; Mortimer, E. F. "Uma metodologia para análise da dinâmica entre zonas de um perfil conceitual no discurso da sala de aula." In: SANTOS, F. M. T.; GRECA, I. M. (Orgs.). A pesquisa em ensino de ciências no Brasil e suas metodologias. ljuí: Unijuí, 2006.

Azevedo, M. C. P. S. de. "Ensino por investigação: problematizando as atividades em sala 
de aula." In: CARVALHO, Anna Maria Pessoa de. (Org.). Ensino de ciências: unindo a pesquisa e a prática. São Paulo: Thomson, 2005. p. 19-33

Bachelard, G (1938). A formação do espírito científico - contribuição para uma psicanálise do conhecimento. Rio de Janeiro: Contraponto, 2007, 316p.

Bakhtin, M. M. Marxismo e Filosofia da Linguagem. 13. ed. São Paulo: Hucitec, 2009.

Barrelo N. J., Argumentação no discurso oral e escrito de alunos do ensino médio em uma sequência didática da Física moderna. 2010. Dissertação (Mestrado em Educação) - Faculdade de Educação da Usp, . Orientador: Anna Maria Pessoa de Carvalho.

Bybee, R.W. e DeBoer, G.E., "Research on Goals for the Science Curriculum", In: Gabel, D.L.(ed.), Handbook of Research in Science Teaching and Learning, New York, McMillan, 1994.

Biasoto, J.E, O Pensamento em Ação dos Alunos na Resolução de um Problema Experimental de Física, Dissertação de mestrado, IF/FEUSP, São Paulo, 2010.

Brockington, G. A realidade escondida: a dualidade onda - partícula para estudantes do ensino médio. 2005. 341p. dissertação (mestrado em ensino de ciências). IF - FEUSP, São Paulo, 2005

Bueno, Silveira. Grande dicionário etimológico prosódico da língua portuguesa. São Paulo: Saraiva, 8 volumes. 1966.

Capecchi, M.C.V. M e Carvalho, A.M.P, "Argumentação em uma Aula de Conhecimento Físico com Crianças na Faixa de Oito a Dez Anos", Investigações em Ensino de Ciências, v.5, n.2, 171-189, 2000.

Aspectos da Cultura Científica em Atividades de Experimentação nas Aulas de Física, Tese de Doutorado. São Paulo: FE-USP, 2004.

Carmo, A.B., A Linguagem Matemática em uma Aula Experimental de Física, Dissertação de Mestrado. São Paulo: IF-USP e FE-USP, 2006.

Carlsen, W. S. "Language and Science Learning". In: S.K Abell. and N.G. Lederman (org.), Handbook of Research on Science Education (Lawrence Erlbaum Ass. Pub, 2007), p. $57-74$

Carvalho, A.M.P., "Ensino e aprendizagem de ciências: referenciais teóricos e dados empíricos das sequencias de ensino investigativas (SEI)", In LONGHINI, M. C. 
(org.) O Uno e o Diverso na Educação. Uberlândia/MG: EDUFU, 2011

Carvalho, A.M.P., "Building up Explanations in Physics Teaching", International Journal of Science Education, v.26, n.2, 225-237, 2004.

Carvalho, A.M.P e Gil-Pérez, D., Formação de Professores de Ciências - Tendências e Inovações, 6ª . ed, São Paulo, Cortez, 1998.

Carvalho, A.M.P., Vannucchi, A.I., Barros, M.A., Gonçalves, M.E.R. e Rey, R.C., Ciências no Ensino Fundamental - O conhecimento físico. São Paulo: Editora Scipione, 1998.

Clough, M. P. (2007). What is so Important about Asking Questions? lowa Science $\begin{array}{lll}\text { Teachers Journal, } \quad \text { Editorial, } & \text { 34(1), }\end{array}$ http://ists.pls.uni.edu/isti/issues/34/1 winter 07/editorial 34(1).pdf

Cortella, M. S. O que é a pergunta? 1.ed. São Paulo: Cortez, 2008

Driver, R. e Newton, P., Establishing the Norms of Scientific Argumentation in Classrooms, ESERA Conference, Roma, 1997.

Erickson, F., "Qualitative Research Methods for Science Education", in: Fraser, B.J. e Tobin, K.G. (orgs.), International Handbook of Science Education, Part One, Kluwer Academic Publishers, 1998.

Exploratorium Institute for Inquiry, Professional Development Tools for Inquiry $\square$ Based Science. 3. Effective Questioning, San Francisco University, 2006. http://www.exploratorium.edu/ifi/activities

Freire, P., Por uma pedagogia da pergunta. Rio de Janeiro : Paz e Terra, 1985

Freire, P., Pedagogia da autonomia: saberes necessários à prática educativa. São Paulo: Paz e Terra, 2007

Gil-Pérez, D.; Torregroza, M. J.; Ramirez, L.; Dumas Carre, A.; Gofard, M.; Carvalho, A. M P. Questionando a didáctica de resolução de problemas: elaboração de um modelo alternativo. Caderno Catarinense de Ensino de Física, v. 9, n. 1, p. 719, 1992.

Hargie, O. D. W. (1983). "The Importance of Teacher Questions in the Classroom". In M. Stubs and H. Hillier (Eds.), Readings on Language, Schools and Classrooms (pp. 185-192). London: Methuen.

Heidegger, M., Lógica: A Pergunta pela essência da Linguagem. Lisboa: Fundação 
Calouste Gulbenkian, 2008

Jiménez-Aleixandre, M.P., Bugallo Rodríguez, A. e Duschl, R.A., "Doing the Lesson" or

"Doing Science": Argument in High School Genetics, Science Education, v.84, 757-792, 2000.

Lemke, J., "Multiplying Meaning: Visual and Verbal Semiotics in Scientific Text", in: Martin, J.R. e Veel, R. (eds.), Reading Science, Londres, Routledge, 87-113, 1998.

Lemke, J., (1998). Teaching all the language of science: Words, symbols, images and actions. International conference on ideas for a scientific culture (Museo de Cienra / Fondacion La Caixa, Barcelona). [En ligne]. Disponible : http://academic.brooklyn.cuny.edu/education/jlemke/papers/barcelon.htm

Leontiev, A., O desenvolvimento do psiquismo. Lisboa: Horizonte, 1978.

Locatelli, R.J., Uma Análise do Raciocínio Utilizado pelos Alunos ao Resolverem os Problemas Propostos nas Atividades de Conhecimento Físico, Dissertação apresentada ao Instituto de Física e à Faculdade de Educação da USP, 2006.

Lorencini Júnior, A., "O ensino de Ciências e a formulação de perguntas e respostas em sala de aula". In: Cadernos de Textos da III Escola de Verão. Serra Negra, São Paulo: FEUSP, 1994, p. 128-137

Martens, M.L., Productive questions: Tools for supporting constructivist learning. Science Children. 1999. 53:7. [NCES] National Center for Education Statistics. Highlights from the Third International Mathematics and Science Study-Repeat (TIMSS-R). 2000. http://nces.ed.gov/timss/timss-r/highlights.asp

Martins, I., Ogborn, J; Kress, G. Explicando uma explicação. Ensaio - Pesquisa em educação em Ciências, Belo Horizonte, v. 1, n. 1, p. 1-14, 1999.

Martins, I., "Dados como diálogo: construindo dados a partir de registros de observações de sala de aula". In: Santos, F. M. T.; Greca, I. M.. (Org.). A Pesquisa em Ensino de Ciência no Brasil e suas Metodologias. 1 ed. ljuí: Editora da Unijuí, 2006, v. , p. 297-321.

Menezes, L. (1996). A importância da pergunta do professor na aula de Matemática. In J. Ponte, C. Monteiro, M. Maia, L. Serrazina, C. Loureiro Orgs. Desenvolvimento Profissional dos Professores de Matemática: Que Formação? (pp. 105-116). Secção de Educação Matemática - Sociedade Portuguesa de Ciências da Educação: Lisboa. 
Mortimer, E. F.; Scott, P. Atividade discursiva nas salas de aula de ciências: uma ferramenta sociocultural para analisar e planejar o ensino. Investigações em Ensino de Ciências, Porto Alegre, v. 7, n. 3, p. 3, 2002. Disponível em: <http://www.if.ufrgs.br/public/ensino/vol7/n3/v7_n3_a7.htm >. Acesso em: 29 abr. 2007.

Rodrigues, T. A.; Borges, A. T. O Ensino De Ciências Por Investigação: Reconstrução Histórica. XI Encontro de Pesquisa em Ensino de Física - Curitiba -. 2008.

Rosa, J. G. Grande Sertão Veredas, 3aㅗ edição, Rio de Janeiro: José Olympio, 1993.

Roth, W.M., Competent Workplace Mathematics: How Signs Become Transparent, International Journal of Computers for Mathematical Learning, v.8, n.3, 161-189, 2003.

Sasseron, L.H. e Carvalho, A.M.P. Construindo argumentação na sala de aula: a presença do ciclo argumentativo. Ciência \& Educação, no prelo.

Sasseron, L.H., Alfabetização Científica no ensino Fundamental - Estrutura e Indicadores deste processo em sala de aula, tese apresentada à Faculdade de Educação da USP, 2008.

Sasseron, L.H. e Carvalho, A.M.P. Almejando a alfabetização científica no ensino fundamental: a proposição e a procura de indicadores do processo. Investigações em Ensino de Ciências, v.13 n.3 pp. 333-352, 2008.

Silva, J. F.. Apropriação da linguagem científica por parte dos alunos em uma sequência de ensino de física. 2009. Dissertação (Mestrado em FÍSICA) Interunidades Física e FEUSP, Orientador: Anna Maria Pessoa de Carvalho.

Vieira, R. D. ; Nascimento, S. S. Uma visão integrada dos procedimentos discursivos didáticos de um formador em situações argumentativas de sala de aula. Ciência e Educação (UNESP), v. 15, p. 1-15, 2009.

Vygotsky, L. S. Pensamento e linguagem. 2. ed. São Paulo: Martins Fontes, 2000.

Wertsch,J. La Mente en Acción. Buenos Aires: Aique, 1999

Yore, L.D., Bisanz, G.L e Hand, B.M., Examining the Literacy Component of Science Literacy: 25 Years of Language Arts and Science Research, International Journal of Science Education, v. 25, n. 6, 689-725, 2003. 


\section{ANEXO A \\ Do real clássico ao ideal quântico: Uma sequência de aulas para introduzir o tema dualidade onda-partícula no ensino médio. Informações gerais sobre a sequência de aulas (11 aulas)}

A sequência se inicia com uma revisão das noções básicas de óptica clássica e de diferentes modelos para a luz (raio luminoso, modelo corpuscular e ondulatório).

Após construir e ajustar o interferômetro de Mach-Zehnder (MZ); discutimos o comportamento da luz no interferômetro e seguimos explorando o interferômetro como experimento de pensamento com fótons únicos. Visamos assim estudar a dualidade onda-partícula, o princípio da complementaridade e a noção de superposição de estados quânticos contemplando a dimensão 
epistemológica do conhecimento físico.

\section{Objetivos:}

1)Incentivar o aluno a refletir:

- sobre a natureza do fenômeno quântico considerando-o a partir de uma abordagem relacional, ou seja, partindo de diferentes pontos de vista: do objeto observado, do instrumento de medida e do papel observador.

- sobre as implicações filosóficas da física quântica para o desenvolvimento do conhecimento físico.

- sobre o conhecimento físico e tecnológico como construção humana e a noção de realidade.

2) Desenvolver no aluno competências que deverão manifestar-se em suas habilidades para racionar matematicamente (formal), empregar conceitos adequadamente (conceitual) e observar e descrever objetivamente fenômenos físicos (fenomenológica).

3) Estimular o aluno a pensar e a argumentar criticamente desenvolvendo sua capacidade de trabalhar em grupo, socializar seu conhecimento, contrapor opiniões diferentes e expressar-se de maneira clara e direta.

\section{Conteúdo Físico (11 aulas)}

Conceitos de óptica geométrica: reflexão, refração, transmissão e propagação da luz

Modelos para o comportamento da luz: raio, corpuscular e ondulatório

Funcionamento do interferômetro

Interferência

Laser

Fóton

Dualidade onda-partícula

Interpretações de mecânica quântica

\section{Metodologia}

- realização de aulas expositivas, demonstrações (professor).

- simulações experimentais (alunos)

- realização de atividades experimentais (trabalho em grupo)

- discussões em sala de aula

- $\quad$ uso de textos de apoio e de vídeos e DVDs educacionais.

\section{Aula 1 : 0 universo físico}

Objetivos:

- Apresentação da proposta de aulas para os alunos.

- Levantar as concepções dos alunos sobre as seguintes questões (questionário para responder em classe):

1. Como você explicaria o que é "física" para alguém que nunca estudou física?

2. O que é física quântica para você?

3. Você gostaria de aprender algo sobre física quântica? O quê? Por quê?

- Motivar os alunos a refletirem sobre o tema "a natureza do conhecimento físico".

Conteúdos:

- O universo físico (o que existe no universo? O que existe no universo físico? Qual a diferença entre esses dois universos?).

- Trabalhar conceito de trajetória e caracterizar os "objetos tipo partícula" contrapondo-os aos "objetos tipo onda".

- A natureza do conhecimento físico (como a física "funciona"? Qual o papel da observação, dos modelos, das leis gerais, da matemática, das representações gráficas, etc.?)

Materiais e recursos:

- Apresentação da sequência didática (apresentação data-show: conhecimento físico).

- Questionário.

- Material para atividade do tatuzinho (tatuzinhos, tubos de mangueira transparente, réguas, papel milimetrado, cronômetro, etc.).

Momentos: 
- O professor apresenta em linhas gerais os objetivos e o conteúdo das aulas da sequência de aulas.

- O professor apresenta o esquema do vetor epistemológico (apresentação data-show) discutindo brevemente o processo de construção do conhecimento científico e relacionando essa discussão com a construção do fenômeno quântico que será estudado ao longo dos quatro episódios epistemológicos.

- Os alunos respondem o questionário proposto pelo professor.

O professor propõe a atividade do tatuzinho:

- O professor fornece as instruções e o material necessário para a realização da atividade do tatuzinho.

- Os alunos trabalham em grupos na atividade do tatuzinho.

- O professor propõe e estimula uma discussão sobre a natureza do conhecimento físico baseado na atividade do tatuzinho de modo a levantar as concepções dos alunos sobre o que é relevante/irrelevante para o estudo do comportamento do tatuzinho do ponto de vista da física (ex. relevante: perceber a relação entre a distância percorrida e o tempo; irrelevante: considerar o estado emocional do tatuzinho).

- O professor sistematiza as ideias dos alunos sobre o que pertence ao universo e ao universo físico sistematizando a discussão sobre o conhecimento físico a exemplo da atividade do tatuzinho (ex. discute com os alunos o que essa atividade poderia significar para um biólogo, um físico, um psicólogo, um trabalhador rural, uma pessoa que não frequentou a escola etc.).

\section{Aula 2: O nascimento da física quântica}

Objetivos:

- Contextualizar o nascimento da física quântica (problema prático ligado a questão da radiação do corpo negro e da necessidade de adaptação da teoria aos dados experimentais).

Conteúdos:

- História da física antes de 1900 (modelo ondulatório bem estabelecido).

- História da física por volta de 1900 (problema: determinar a melhor fonte de luz para iluminar as cidades europeias: iluminação a gás ou iluminação elétrica recém descoberta; necessidade de comprar fontes luminosas diferentes: corpo negro como fonte de luz ideal, quantização da radiação por Planck: nascimento da física quântica).

Materiais e recursos:

- Apresentação data-show (o nascimento da física quântica).

- Textos de apoio para os alunos.

- Fontes luminosas diferentes (lampião de gás e luz elétrica comum). Momentos:

- O professor apresenta em linhas gerais o modelo corpuscular de Newton e o modelo ondulatório salientando que esses dois modelos são contraditórios.

- O professor chama a atenção para o fato de que no final do século XIX, período que antecede o nascimento da mecânica quântica, o modelo ondulatório era o modelo aceito pela comunidade científica.

- O professor mostra as duas fontes luminosas (gás e eletricidade) e pede para que os alunos as comparem e determinem qual é que mais ilumina, qual consome mais energia, etc. (o professor salienta a dificuldade de uma avaliação subjetiva e a necessidade de realizar medidas mais precisas para comparar diferentes fontes luminosas).

- O professor apresenta e contextualiza o momento histórico de nascimento da mecânica quântica (problema prático era comparar duas fontes de luz diferentes e daí a necessidade de se utilizar uma fonte padrão de comparação, a fundação do instituto de física do reino em Berlim, as medidas dos espectros etc.).

\section{Bloco Temático: Trabalhando com os componentes ópticos do interferômetro de Mach- Zehnder Informações gerais sobre o bloco:}

No primeiro episódio temático o tema central das aulas baseia-se na observação do comportamento de um feixe luminoso emitido por uma fonte laser ao interagir com espelhos 
planos, semiespelhos, lentes e anteparos opacos (componentes ópticos básicos para a construção de um interferômetro de Mach-Zehnder clássico).

Nesse bloco os alunos devem "experimentar" com objetos reais e concretos (espelhos, semiespelhos etc.) paralelamente com objetos de pensamento (modelos propostos para explicar o comportamento da luz como, por exemplo, o raio luminoso, o modelo corpuscular de Newton e o modelo ondulatório) e, assim, perceberem a diferença entre essas classes de objetos.

\section{Aula 3: (trabalhar propriedades de reflexão, refração e propagação da luz e a idéia de raio como modelo para a luz) \\ Objetivos:}

- Os alunos devem observar o comportamento do feixe luminoso ao se propagar no espaço e serem capazes de perceber que: a luz se propaga em linha reta, o feixe de laser sofre uma dispersão pequena ao longo de seu percurso até atingir um anteparo opaco e que, ao atingir o anteparo, o raio luminoso produz uma mancha clara praticamente homogênea sobre o mesmo.

- Os alunos devem observar o comportamento da luz ao interagir com o espelho e serem capazes de perceber e expressar oralmente (de forma qualitativa) a lei da reflexão: o ângulo de incidência é igual o ângulo de reflexão.

- Os alunos devem observar o comportamento da luz ao interagir com o semiespelho e serem capazes de perceber e expressar oralmente o fato de que o feixe luminoso ao interagir com o semiespelho é dividido em dois feixes de intensidades aproximadamente iguais sendo que: o feixe que atravessa o semiespelho (feixe transmitido) sofre um desvio na sua direção de propagação e abandona o semiespelho numa direção de propagação paralela à da incidência inicial e o feixe refletido obedece a lei da reflexão.

- Os alunos devem utilizar o modelo de raio luminoso para esquematizar em um desenho o comportamento da luz ao interagir com o espelho e com o semiespelho.

- Os alunos devem ser capazes de diferenciar feixe e raio luminoso (feixe: algo real ligado a Conteúdos: nossa percepção sensorial e raio: objeto construído mentalmente, sem dimensão).

- Reflexão, refração, transmissão e propagação do feixe de luz.

- Conceitos de feixe e raio luminoso.

Materiais e recursos:

- Componentes ópticos necessários para a construção de um interferômetro de MachZehnder (fonte de laser, dois espelhos planos, dois semiespelhos, dois anteparos opacos).

- Talco ou pó de giz para refletir o feixe de laser.

Dicas para o professor:

- As atividades propostas no presente episódio temático devem, se possível, ser realizadas em uma sala escura.

- Se não houver material suficiente para que os alunos realizem as atividades propostas em grupos, o professor pode realizá-las como demonstração. Neste caso, se possível, usar uma câmera de vídeo para captar a imagem dos experimentos feitos pelo professor e projetá-la em uma tela para que todos os alunos possam observar e interagir com as ações do professor durante as demonstrações experimentais.

- ATENÇÃO: alertar os alunos para os perigos da utilização do laser (nunca olhar diretamente para o feixe!).

Momentos:

1) O professor propõe que os alunos realizem em grupos de aproximadamente 5 componentes:

- Projetar o feixe de laser sobre o espelho variando o ângulo de incidência.

OBS: para visualizar a trajetória do feixe pode-se espalhar um pouco de talco ou pó de giz na região.

- Observar o comportamento do feixe refletido buscando estabelecer uma relação entre o ângulo de incidência e o ângulo de reflexão.

- Desenhar numa folha de papel o que foi observado.

- Repetir o procedimento descrito anteriormente utilizando um semiespelho (iniciar com ângulo de incidência de aproximadamente 45) buscando estabelecer uma relação entre o feixe incidente e os feixes transmitidos e refletidos.

2) O professor faz as seguintes demonstrações em sala de aula (ou propõe que os alunos as 
realizem em grupos):

- Projetar o feixe de laser sobre um anteparo opaco colocado a aproximadamente $5 \mathrm{~m}$ da fonte.

- Comparar o diâmetro do feixe próximo a fonte com o diâmetro do feixe sobre o anteparo. OBS: o laser não deve apresentar uma dispersão grande.

- Desenhar o que foi observado.

OBS: A intenção é que os alunos percebam que a noção de feixe se diferencia da noção de raio. Numa experiência de pensamento podemos reduzir a espessura do feixe de modo a obter um feixe tão estreito, que somente pode existir como uma construção geométrica. Esse não seria mais um feixe, mas sim um raio! A ideia é chamar a atenção dos alunos para o processo de modelagem do feixe transformando-o em raio e então estender essa discussão para o espelho, o semiespelho, os anteparos etc. O que é um espelho ideal? (não tem dimensão, não há perda de energia etc.).

Aula 4: (modelo corpuscular de Newton X modelo ondulatório)

Objetivos:

- Os alunos devem conhecer diferentes modelos para a luz: raio, o modelo corpuscular e o modelo ondulatório.

- Os alunos devem reconhecer as diferenças entre os modelos e perceber as limitações e os Conteúdos: domínios de aplicação de cada modelo.

- Modelo corpuscular de Newton.

- Modelo ondulatório.

Materiais e recursos:

OBS: os alunos devem trazer como tarefa realizada extraclasse uma pequena pesquisa sobre o tema: modelo corpuscular e modelo ondulatório.

- Laser e um anteparo com duas fendas (experimento simples de dupla fenda).

- Uma lata de tinta spray e um anteparo com duas fendas (analogia ao experimento de dupla fenda).

Momentos:

- O professor retoma os resultados da aula anterior solicitando que os alunos consultem as anotações que fizeram quando observaram o comportamento da luz no espelho, no semiespelho e no anteparo opaco e consultem também a pesquisa que realizaram em casa.

- O professor divide a classe em dois grupos: "grupo onda" e "grupo partícula" e promove um debate entre os dois grupos propondo que: o grupo ondas tente explicar os fenômenos observados na aula anterior com o modelo ondulatório e o grupo partícula com o modelo corpuscular.

OBS: é essencial que os alunos tenham feito anteriormente em casa uma pesquisa sobre o modelo ondulatório e o modelo corpuscular.

- O professor sistematiza as discussões na lousa e mostra que o modelo corpuscular (de Newton) apresenta limitações para explicar o fenômeno de refração e de interferência.

- O professor mostra o comportamento das partículas de tinta no experimento análogo de dupla fenda realizado com tinta spray e contrapõe esse ao experimento de dupla fenda com laser (aparecimento de um padrão de interferência) salientando que o fenômeno de interferência não pode ser explicado com o modelo corpuscular.

OBS: como alternativa ao experimento com o spray pode-se utilizar também um tabuleiro de Galton com duas fendas.

\section{Bloco temático: Montando e ajustando o interferômetro de Mach-Zehnder Informações gerais sobre o bloco:}

No segundo episódio temático o conteúdo central das aulas é a montagem, ajuste e observação do interferômetro de Mach-Zehnder.

Neste bloco de aulas os alunos devem perceber que as observações em física são imediatas. Fazemos hipóteses a priori. 
Aulas 5 e 6: (observar o interferômetro de Mach-Zehnder clássico e real)

Objetivos:

- Montar o interferômetro de Mach-Zehnder.

- Observar os padrões de interferência (complementares).

- Adquirir habilidade experimental (ajuste no interferômetro).

Conteúdos:

- O interferômetro de Mach-Zehnder (trabalhar dois grupos: MZ real clássico e simulação do $\mathrm{MZ}$ ).

Materiais e recursos:

- Apresentação (nascimento do interferômetro de MZ).

- KIT interferômetro de Mach-Zehnder real clássico.

- Simulação do interferômetro de MZ (software da universidade de Munique).

Momentos:

- - O professor apresenta brevemente o interferômetro de $M Z$ e conta um pouco de sua história e de origem (a partir de um arranja experimental do interferômetro de Jamin).

- O professor divide a classe em dois grupos: um grupo vai trabalhar com o interferômetro real clássico e o outro com o interferômetro virtual (no laboratório de informática).

Para o grupo que vai trabalhar com o interferômetro real clássico:

- O professor apresenta o interferômetro de MZ real clássico e salienta a formação de padrões de interferência complementares chamando a atenção para a validade do modelo ondulatório como modelo adequado para explicar o comportamento da luz.

- O professor desmonta o interferômetro e propõe que os alunos em grupo montem e ajustem o aparelho de modo a obterem padrões de interferência semelhantes aos observados anteriormente.

- O professor pede que os alunos desenhem o esquema do interferômetro numa folha de papel e proponham uma explicação para o aparecimento de interferência baseada no modelo ondulatório.

Para o grupo que vai trabalhar com o interferômetro virtual:

- Simulação do interferômetro (software livre).

Bloco temático: Transformando o interferômetro de Mach-Zehnder real clássico em um interferômetro ideal

Aula 7: (modelando o interferômetro de MZ)

Objetivos:

- Os alunos devem ser capazes de perceber e listar os fatores que devem ser desconsiderados e os que precisam ser considerados no processo de modelagem do interferômetro de $\mathrm{MZ}$ (transformação do interferômetro real clássico em um interferômetro ideal).

Conteúdos:

- Modelagem do interferômetro de MZ

- Laser

Materiais e recursos:

- KIT interferômetro de MZ real clássico.

- Apresentação data-show (esquema do interferômetro de MZ ideal clássico).

- Guia para relatório.

Momentos:

- O professor apresenta novamente o interferômetro real e o interferômetro esquematizado e propõe uma discussão entre os alunos visando levantar suas argumentações sobre o processo de modelagem do interferômetro (o que é espelho, semi-espelho ideal, o que significa que o interferômetro está ajustado, a necessidade de uma fonte laser, etc.).

- Os alunos trabalham em grupos completando o guia para o relatório.

Aula 8: (a matemática do interferômetro de MZ) Objetivos:

- Os alunos devem compreender o funcionamento do interferômetro de MZ e do modelo ondulatório para a luz a partir de uma modelagem matemática do fenômeno. 
Conteúdos:

- Modelagem matemática do interferômetro de MZ.

Materiais e recursos:

- Apresentação data-show (como funciona o interferômetro de MZ).

- Roteiro de trabalho (como funciona o interferômetro de MZ).

Momentos:

- O professor apresenta a modelagem matemática do interferômetro.

- Os alunos trabalham em grupos completando a folha de trabalho.

\section{Bloco temático: Transformando o interferômetro de Mach-Zehnder clássico em um} interferômetro quântico

Aula 9: (construindo um interferômetro quântico)

Objetivos:

- Os alunos devem ser capazes de perceber e listar os fatores que devem ser desconsiderados e os que precisam ser considerados no processo de transformação do interferômetro ideal clássico em um interferômetro ideal quântico (exemplificando: o feixe luminoso deve ser tênue o suficiente para que somente um único fóton de cada vez percorra o interferômetro, os anteparos devem ser substituídos por detectores sensíveis o

Conteúdos: suficiente para registrar o fóton, etc.).

- Interferômetro de MZ quântico.

- Dualidade onda-partícula.

Materiais e recursos:

- Apresentação data-show (como funciona o interferômetro de $M Z$ quântico).

- Roteiro de trabalho (como funciona o interferômetro de MZ quântico).

Momentos:

- O professor retoma o esquema do interferômetro de $M Z$ ideal clássico e discute com os alunos a transformação do interferômetro clássico em interferômetro quântico.

- O professor incentiva os alunos a perceberem o comportamento "estranho" do fóton e a problemática da dualidade onda-partícula.

- Os alunos trabalham em grupos completando o roteiro de trabalho.

Aula 10: (interpretações da mecânica quântica)

Objetivos:

- Os alunos devem conhecer quatro interpretações para o comportamento do fóton no interferômetro de MZ.

- Os alunos devem perceber que nenhuma das quatro interpretações explica o comportamento do fóton de forma completamente satisfatória.

- Os alunos devem reconhecer que, embora não exista uma interpretação completamente satisfatória para o comportamento dual dos objetos quânticos, a teoria quântica é a teoria física mais bem-sucedida desenvolvida até hoje pelos físicos e que essa teoria não só fornece previsões experimentais corretas como também possui aplicações práticas.

Conteúdos:

- Interpretações para o comportamento do fóton no interferômetro de $M Z$ (interpretação corpuscular, ondulatória, dualista-realista, complementaridade).

Materiais e recursos:

- Apresentação data-show.

- Momentos:

- O professor apresenta as diferentes interpretações.

- O professor promove um debate entre os alunos. Os alunos trabalham em grupos e cada grupo deve defender uma das quatro interpretações apresentadas.

- O professor sistematiza a aula, salientando que nenhuma das interpretações é totalmente satisfatória para explicar completamente o comportamento do fóton no interferômetro.

Aula 11: O sentido das coisas

Objetivos: 
- Discutir a natureza da ciência e da realidade física (nova visão de mundo da física quântica).

Conteúdos:

- Natureza da ciência e noção de realidade na física.

Materiais e recursos: questionário da sequência proposta por Brockington (recurso de ensino 3 )

Momentos:

- O professor promove o debate, iniciando a discussão a partir das hipóteses dos alunos a respeito do que observaram na sala.

- O professor sistematiza a sequência de aulas, retomando a discussão da primeira aula (o universo físico). 
ANEXO B

TRANSCRIÇÕES E CLASSIFICAÇÕES DA AULA 2

\section{Momento 1: Organização da aula, lembrança das aulas anteriores e introdução da} atividade

\begin{tabular}{|c|c|c|c|c|c|}
\hline$T$ & Falas transcritas & Descrição & $\begin{array}{l}\text { Reformuland } \\
\text { o a } \\
\text { pergunta. }\end{array}$ & $\begin{array}{l}\text { Classificaç } \\
\text { ão }\end{array}$ & $\begin{array}{l}\text { Indicador de } \\
\text { AC }\end{array}$ \\
\hline 01 & $\begin{array}{l}\text { Prof.: No nosso último encontro, é, nós respondemos a algumas } \\
\text { questões. Olha, pessoal, eu vou contar com a colaboração, } \\
\text { caso contrário nós sentaremos em ordem numérica, certo Joe? } \\
\text { Então, no nosso último encontro a gente respondeu algumas } \\
\text { questões sobre o efeito fotoelétrico, e aí ao invés da gente já } \\
\text { trazer as respostas direto daquelas questões, nós vamos fazer } \\
\text { uma pequena passagem, ou a gente pode pular isso também, } \\
\text { porque acho que vocês já tão "experts". }\end{array}$ & & & & \\
\hline 02 & Nicolau:Por favor não & & & & \\
\hline 03 & $\begin{array}{l}\text { Prof.: Quando vocês quiserem a gente começa, ou se não } \\
\text { quiserem eu já fiz chamada podem ir. Nicolau tudo em aí? Bom } \\
\text { então vamos supor que todos vocês entenderam eu vou passar } \\
\text { rapidamente pela apresentação, se alguém tiver dúvida pára, se } \\
\text { não tiver dúvida a gente vai em frente, ao final dessa aula eu } \\
\text { passo uma outra seqüência de exercícios pra vocês, ok? Muito } \\
\text { bem. Então, o que nós faremos nessa aula é... a gente revisitar } \\
\text { o que a gente estudou ao longo desse ano pra gente chegar até } \\
\text { o efeito fotoelétrico, tá? Tá dando pra ler aí? É que a gente não } \\
\text { pode apagar completamente se não a câmera não consegue } \\
\text { filmar vocês, tá. O que ficar muito em dúvida, num momento que } \\
\text { precisar ficar mais claro a gente apaga nesse momento. Então, } \\
\text { o que a gente viu até agora? }\end{array}$ & & & & \\
\hline 04 & Luis: Não dá pra enxergar.. & & & & \\
\hline 05 & Prof.: Calma que eu leio. & & & & \\
\hline 06 & A3 (não identificado): Apaga a luz. & & & & \\
\hline 07 & $\begin{array}{l}\text { Prof.:Vou repetir que você não prestou atenção, a gente não } \\
\text { pode apagar a luz porque se apagar a luz a câmera não } \\
\text { consegue filmar vocês no escuro, então quando for necessário a } \\
\text { gente apaga pra visão específica do quadro que for necessário, } \\
\text { se não a gente vai ler com vocês. O Joe, faz uma gentileza pra } \\
\text { mim senta na bancada ou pode sair. Mais alguém? Então, nós } \\
\text { vimos um pouquinho de modelos, quando a gente discutiu } \\
\text { modelo a gente discutiu os modelos que a física usa pra explicar } \\
\text { a natureza das coisas, onda ou partícula, a gente verificou as } \\
\text { propriedades elétricas e magnéticas da matéria. Quando a } \\
\text { gente começou a estudar essas propriedades elétricas e } \\
\text { magnéticas a gente falou então e discutiu um pouquinho sobre } \\
\text { a indução de campos, particularmente campo elétrico e campo } \\
\text { magnético. Depois a gente começou a estudar ondas, e aí a } \\
\text { gente foi ver as propriedades das ondas, o que definia uma } \\
\text { onda, quais as características que uma onda apresenta, a gente } \\
\text { estudou depois luz, depois de luz a gente foi verificar os } \\
\text { espectros, e aí a gente se deparou com dois tipos de espectros, } \\
\text { contínuos e discretos, e pra explicar o modelo... pra explicar os } \\
\text { espectros discretos a gente foi então fazer uso do modelo } \\
\text { atômico de Bohr. E aí nas duas últimas aulas a gente ta } \\
\text { conversando um pouquinho sobre o efeito fotoelétrico. Pra } \\
\text { verificar se a gente ta lembrando as coisas vamos dar uma } \\
\text { pequena passadinha por esses diversos tópicos. Então a gente } \\
\text { quer chegar na discussão de dualidade onda-partícula, e pra } \\
\text { chegar a isso a gente começou discutindo o que são ondas, }\end{array}$ & & & & \\
\hline
\end{tabular}




\begin{tabular}{|l|l|l|l|l|}
\hline & $\begin{array}{l}\text { certo? Então, o que definia, o que caracterizava pra gente } \\
\text { onda? Uma onda transporta energia, sem que haja transporte } \\
\text { de matéria, ela não é... ela se espalha, não tá bem localizada. E } \\
\text { a gente tem dois fenômenos bastante associados às ondas que } \\
\text { são os fenômenos da sobreposição de ondas e de interferência. }\end{array}$ & & & \\
\hline 08 & A4 (não identificado): Você vai dar uma provinha? & & & \\
\hline
\end{tabular}

\section{Momento 2: Retomada e discussão de conceitos e fenômenos ópticos: (interferência, efeito fotoelétrico, interferência)}

\begin{tabular}{|c|c|c|c|c|c|}
\hline $\mathbf{T}$ & Falas transcritas & Descrição & $\begin{array}{c}\text { Reformula } \\
\text { ndo a } \\
\text { pergunta. }\end{array}$ & $\begin{array}{l}\text { Classifica } \\
\text { ção }\end{array}$ & $\begin{array}{l}\text { Indicador de } \\
\text { AC }\end{array}$ \\
\hline 09 & $\begin{array}{l}\text { Prof.: Não. Ok? Diferentemente em partículas o que a gente } \\
\text { tem? Partículas eu posso localizar, posso saber a posição dela } \\
\text { em cada instante, e eu posso observar a sua trajetória. } \\
\text { Também transporta energia, correto? Então ondas e partículas } \\
\text { são duas maneiras diferentes e excludentes da gente explicar a } \\
\text { natureza. E aí é onde estão as duas principais diferenças, no } \\
\text { caso aí a localização, a partícula ta sempre bem localizada, eu } \\
\text { consigo dizer onde ela se encontra, e nas ondas eu tenho o } \\
\text { fenômeno da interferência, certo? Bom, aí a gente estudou } \\
\text { essas propriedades. Quando a gente começou a estudar a luz, } \\
\text { pois não Priscila. Fala pra classe. Quando a gente começou a } \\
\text { estudar a luz, que a gente foi estudar a questão sa visão, da } \\
\text { cor, a gente começou a estudar o espectroscópio, a gente foi } \\
\text { caminhando pra idéia de que a luz é uma onda, onda } \\
\text { eletromagnética. Então a gente foi observando ao longo das } \\
\text { aulas, foi observando nos experimentos, nas experiências que } \\
\text { nós fomos fazendo a gente foi concluindo que a luz é uma } \\
\text { onda. Tudo bem até aí? Tá muito rápido? Bom, aí quando nós } \\
\text { começamos a observar os espectros nos espectroscópios a } \\
\text { gente se deparou com dois tipos de espectro, contínuo e } \\
\text { discreto. Fala aí Teresa o que é um espectro contínuo? }\end{array}$ & $\begin{array}{l}\text { 1, está } \\
\text { retomando } \\
\text { conceitos } \\
\text { anteriores em } \\
\text { uma revisão. } \\
\text { Pergunta } \\
\text { objetiva sobre } \\
\text { o que é } \\
\text { aquele } \\
\text { conceito. }\end{array}$ & $\begin{array}{l}\text { O que é um } \\
\text { espectro } \\
\text { contínuo? }\end{array}$ & $\begin{array}{l}\text { Pergunta } \\
\text { de } \\
\text { sistematiz } \\
\text { ação }\end{array}$ & \\
\hline 10 & Teresa:Não sei & & & & \\
\hline 11 & Prof.: Dá um exemplo. & & & & \\
\hline 12 & $\begin{array}{l}\text { Teresa:Aquele que a gente viu na apostila da luz que passa } \\
\text { pelo prisma }\end{array}$ & & & & $\begin{array}{l}\text { Classificação } \\
\text { de informações }\end{array}$ \\
\hline 13 & Prof.: Que luz? & $\begin{array}{l}\text { Procura que a } \\
\text { aluna } \\
\text { explique } \\
\text { melhor o } \\
\text { exemplo. }\end{array}$ & $\begin{array}{l}\text { Que tipo luz } \\
\text { você se } \\
\text { refere? }\end{array}$ & $\begin{array}{l}\text { Pergunta } \\
\text { de } \\
\text { sistematiz } \\
\text { ação. }\end{array}$ & \\
\hline 14 & Teresa:A luz normal. & & & & $\begin{array}{l}\text { Organização de } \\
\text { informações. }\end{array}$ \\
\hline 15 & $\begin{array}{l}\text { Prof.: Que luz que é normal? Essa luz é normal e essa é } \\
\text { anormal? }\end{array}$ & $\begin{array}{l}\text { Apenas faz } \\
\text { uma anedota. }\end{array}$ & & & \\
\hline 16 & Teresa: Ah.. não sei professor. & & & & \\
\hline 17 & Prof.: Fala aí Cristina, e sem resmungar. & & & & \\
\hline 18 & Cristina:Não sei. & & & & \\
\hline 19 & $\begin{array}{l}\text { Prof.: Sabe Priscila? Fala Clara. Dá um exemplo de espectro } \\
\text { contínuo. }\end{array}$ & & & & \\
\hline 20 & Clara: O arco íris. & & & & $\begin{array}{l}\text { Seriação de } \\
\text { informações. }\end{array}$ \\
\hline 21 & Prof.: O arco íris. Porque que é contínuo? & $\begin{array}{l}\text { Retomando } \\
\text { conceitos. } \\
\text { Busca uma } \\
\text { explicação da } \\
\text { aluna sobre a } \\
\text { continuidade } \\
\text { do arcoiris } \\
\end{array}$ & $\begin{array}{l}\text { Porque o } \\
\text { arcoiris tem } \\
\text { um espectro } \\
\text { de luz } \\
\text { contínuo? }\end{array}$ & $\begin{array}{l}\text { Pergunta } \\
\text { de } \\
\text { sistematiz } \\
\text { ação }\end{array}$ & \\
\hline
\end{tabular}




\begin{tabular}{|c|c|c|c|c|c|}
\hline 22 & $\begin{array}{l}\text { Clara: Porque é uma seqüência. Você não tem um "buraco" } \\
\text { sem... luz. Fica tudo junto, vai passando gradualmente de uma } \\
\text { cor pra outra. }\end{array}$ & & & & Justificativa. \\
\hline 23 & Prof.: Não tem o que Gilberto? & $\begin{array}{l}\text { Quer saber o } \\
\text { que o aluno } \\
\text { disse. }\end{array}$ & & & \\
\hline 24 & Gilberto: Não, é que nesse não tem interferência. & & & & justificativa \\
\hline 25 & Prof.: Interferência do que? & $\begin{array}{l}\text { Quer que o } \\
\text { aluno se } \\
\text { expresse } \\
\text { melhor }\end{array}$ & & & \\
\hline 26 & Gilberto: Do espectro contínuo.... & & & & \\
\hline 27 & Prof.: Mas a gente viu que interferência é outra coisa. & & & & \\
\hline 28 & José: É discreto porque não tem todas as cores. & & & & $\begin{array}{l}\text { Levantamento } \\
\text { de hipótese. }\end{array}$ \\
\hline 29 & $\begin{array}{l}\text { Prof.: Calma nós vamos chegar lá. Primeiro vamos lá, contínuo } \\
\text { ta claro pra todo mundo? Ta, quando você tem lá uma faixa de } \\
\text { radiação em que você tem todos os valores possíveis ali, a } \\
\text { gente não consegue distinguir quando passa de um valor pra } \\
\text { outro, aí o exemplo que a Clara deu foi do arco íris, a gente vê } \\
\text { a decomposição das cores, certo? Como tá lá no desenho, } \\
\text { passa luz branca pelo prisma e aí do outro lado a gente têm a } \\
\text { decomposição da luz branca em todas as cores possíveis, } \\
\text { certo? Tudo bem? Tá, e o discreto? }\end{array}$ & $\begin{array}{l}\text { Retomando } \\
\text { conceitos. } \\
\text { Busca } \\
\text { explicação do } \\
\text { que seja um } \\
\text { espectro } \\
\text { discreto. }\end{array}$ & $\begin{array}{l}\text { O que é um } \\
\text { espectro } \\
\text { discreto de } \\
\text { luz? }\end{array}$ & $\begin{array}{l}\text { Pergunta } \\
\text { de } \\
\text { sistematiz } \\
\text { ação }\end{array}$ & \\
\hline 30 & Augusto: [inaudível] & & & & \\
\hline 31 & $\begin{array}{l}\text { Prof.: Quando você tem algumas cores, não é isso? Você tem } \\
\text { brancas ou linhas e você tem outros valores que não. }\end{array}$ & & & & \\
\hline 32 & $\begin{array}{l}\text { A11 (não identificado): Quando você tem uma radiação que não } \\
\text { tem todas as cores, aí você consegue ver quando passa de } \\
\text { uma cor pra outra. }\end{array}$ & & & & Explicação. \\
\hline 33 & $\begin{array}{l}\text { Prof.: Tá fala. isso? E aí a gente tem alguns exemplos que a } \\
\text { gente observou lá da luz vinda de alguns lugares. E a gente } \\
\text { tinha visto lá também a diferença entre espectro de emissão e } \\
\text { de absorção, né? Bom, aí surge esse fenômeno que a gente } \\
\text { discutiu nas duas ultimas aulas que é o efeito fotoelétrico. O } \\
\text { que é efeito fotoelétrico Virgínia?* O desenho ajuda vocês } \\
\text { olha... o que tá acontecendo? }\end{array}$ & $\begin{array}{l}\text { *retomando } \\
\text { conceitos. } \\
\text { Invoca o } \\
\text { desenho para } \\
\text { responder a } \\
\text { algo que eles } \\
\text { já viram. } \\
\text { Requer } \\
\text { observação } \\
\text { sobre o } \\
\text { fenômeno. } \\
\end{array}$ & $\begin{array}{l}\text { *O que é o } \\
\text { efeito } \\
\text { fotoelétrico? } \\
\text { De acordo } \\
\text { com o } \\
\text { desenho o } \\
\text { que } \\
\text { acontece no } \\
\text { efeito } \\
\text { fotoelétrico? }\end{array}$ & $\begin{array}{l}{ }^{*} \text { Pergunta } \\
\text { de } \\
\text { sistematiz } \\
\text { ação } \\
\text { Perguntas } \\
\text { sobre } \\
\text { dados }\end{array}$ & \\
\hline 34 & $\begin{array}{l}\text { Luis: A luz tá batendo numa placa de metal e no metal tá tendo } \\
\text { emissão de elétrons.. é.. acho que é elétrons mesmo. }\end{array}$ & & & & Explicação \\
\hline 35 & $\begin{array}{l}\text { Prof.: Tá, então eu faço incidir no metal um feixe de luz, quando } \\
\text { a luz bate nesse metal alguns elétrons são emitidos }\end{array}$ & & & & \\
\hline 36 & $\begin{array}{l}\text { Gilberto: Mas na explicação professor dependendo da luz batia } \\
\text { e ia elétrons, dependendo da luz batia e não ia elétrons }\end{array}$ & & & & Justificativa \\
\hline 37 & $\begin{array}{l}\text { Prof.: Muito bem. Mas o fenômeno em si é a emissão dos } \\
\text { elétrons, certo? Tudo bem até aí? Duvida até aí? }\end{array}$ & $\begin{array}{l}\text { Verificando o } \\
\text { entendimento }\end{array}$ & & & \\
\hline 38 & $\begin{array}{l}\text { Clara: Mas você incidi luz no metal e do metal saem os } \\
\text { elétrons? }\end{array}$ & & & & $\begin{array}{l}\text { Organização de } \\
\text { informações. }\end{array}$ \\
\hline 39 & Prof.: Isso. & & & & \\
\hline 40 & Rubens: Professor... & & & & \\
\hline 41 & Prof.: Fala Rubens. & & & & \\
\hline 42 & $\begin{array}{l}\text { Rubens: Tem como descobrir se vai emitir ou não sem fazer o } \\
\text { teste? }\end{array}$ & $\begin{array}{l}\text { A pergunta do } \\
\text { aluno }\end{array}$ & $\begin{array}{l}\text { É possível } \\
\text { descobrir se } \\
\text { há ou não } \\
\text { emissão } \\
\text { sem } \\
\text { verificar na } \\
\text { prática? } \\
\end{array}$ & $\begin{array}{l}\text { Pergunta } \\
\text { de } \\
\text { problemati } \\
\text { zação }\end{array}$ & \\
\hline 43 & Prof.: Como assim? & & & & \\
\hline 44 & $\begin{array}{l}\text { Rubens: Tem alguma outra forma de saber se a luz vai emitir } \\
\text { ou não elétrons, antes de colocar a luz naquele metal, tem } \\
\text { como eu saber se vai emitir? }\end{array}$ & $\begin{array}{l}\text { Reformula a } \\
\text { pergunta }\end{array}$ & $\begin{array}{l}\text { É possível } \\
\text { descobrir se } \\
\text { há ou não } \\
\text { emissão }\end{array}$ & $\begin{array}{l}\text { Pergunta } \\
\text { de } \\
\text { problemati } \\
\text { zação }\end{array}$ & \\
\hline
\end{tabular}




\begin{tabular}{|c|c|c|c|c|c|}
\hline & & & $\begin{array}{l}\text { sem } \\
\text { verificar na } \\
\text { prática? }\end{array}$ & & \\
\hline 45 & $\begin{array}{l}\text { Prof.: Não. Pra você saber se é efeito fotoelétrico o que você } \\
\text { precisa saber, se o elétron vai ser arrancado de lá quando } \\
\text { incide luz, então o que você faz primeiro, você mede pra ver se } \\
\text { tá tendo emissão sem a luz, aí se tiver emissão sem a luz não } \\
\text { é efeito fotoelétrico, lembra que a gente viu? São outras..Âh? }\end{array}$ & & & & Explicação \\
\hline 46 & Patrícia: Depois que sai o elétron do metal o que acontece? & & & & $\begin{array}{l}\text { Organização de } \\
\text { informações. }\end{array}$ \\
\hline 47 & $\begin{array}{l}\text { Prof.: O que ele fez aqui? Que ele mostrou lá o equipamento } \\
\text { naquela simulação que tinha o Einstein falando? Ele colocou } \\
\text { um amperímetro ali e mediu a passagem de corrente elétrica, } \\
\text { não é isso? Então ele vai verificar se tem ou não, aí ele até } \\
\text { colocou uma situação, a gente mediu alguma coisa com a fonte } \\
\text { desligada porque? }\end{array}$ & $\begin{array}{l}\text { Retoma um } \\
\text { detalhe } \\
\text { experimental } \\
\text { da montagem }\end{array}$ & $\begin{array}{l}\text { No } \\
\text { experimento } \\
\text { tivemos que } \\
\text { medir a } \\
\text { corrente } \\
\text { com a fonte } \\
\text { de luz } \\
\text { desligada } \\
\text { por quê? }\end{array}$ & $\begin{array}{l}\text { Pergunta } \\
\text { exploratóri } \\
\text { as sobre } \\
\text { processo. }\end{array}$ & \\
\hline 48 & A18 (não identificado): Tinha luz ambiente. & & & & Explicação \\
\hline 50 & $\begin{array}{l}\text { Prof.: Tinha luz ambiente, então pra eu saber se é efeito } \\
\text { fotoelétrico ou não o que eu faço, deixo completamente no } \\
\text { escuro, sem incidência de luz nenhuma e verifico se tem } \\
\text { emissão ou não, se houver emissão essa emissão não é } \\
\text { devido ao efeito fotoelétrico. Tá? }\end{array}$ & & & & \\
\hline 51 & $\begin{array}{l}\text { Rubens: Antes de eu fazer o experimento, eu sei que daqui a } \\
\text { 10min eu vou lá por o metal na luz, eu quero saber antes de eu } \\
\text { fazer isso tem como eu fazer um cálculo ou algo do tipo, } \\
\text { alguma coisa pra saber se quando eu colocar vai emitir ou } \\
\text { não? }\end{array}$ & $\begin{array}{l}\text { Aluno retoma } \\
\text { a pergunta }\end{array}$ & $\begin{array}{l}\text { É possível } \\
\text { descobrir se } \\
\text { há ou não } \\
\text { emissão } \\
\text { sem } \\
\text { verificar na } \\
\text { prática? }\end{array}$ & $\begin{array}{l}\text { Pergunta } \\
\text { de } \\
\text { problemati } \\
\text { zação }\end{array}$ & \\
\hline 52 & $\begin{array}{l}\text { Prof.: Tem. O que vocês fizeram nos dois últimos exercícios? } \\
\text { Vocês fizerram os cálculos, pra calcular o que? }\end{array}$ & $\begin{array}{l}\text { Responde ao } \\
\text { aluno }\end{array}$ & $\begin{array}{l}\text { Nos } \\
\text { exercícios, } \\
\text { qual era } \\
\text { nosso } \\
\text { objetivo ao } \\
\text { fazer os } \\
\text { cálculos? }\end{array}$ & $\begin{array}{l}\text { Pergunta } \\
\text { exploratóri } \\
\text { a de } \\
\text { processo }\end{array}$ & \\
\hline 53 & Cristina:A energia. & & & & explicação \\
\hline 54 & $\begin{array}{l}\text { Prof.: A energia necessária pra isso acontecer. Só? Saber qual } \\
\text { a energia necessária pra isso acontecer não é suficiente? Oi? }\end{array}$ & & & & \\
\hline 55 & Patrícia: Pra que serve isso aí? & & & & \\
\hline 56 & Prof.: Pra que serve o que? & $\begin{array}{l}\text { Busca } \\
\text { entender a } \\
\text { pergunta do } \\
\text { aluno } \\
\end{array}$ & & & \\
\hline 57 & Patrícia: Aonde isso é usado? & $\begin{array}{l}\text { A aluna } \\
\text { deseja saber } \\
\text { uma } \\
\text { aplicação do } \\
\text { fenômeno. }\end{array}$ & $\begin{array}{l}\text { Em que } \\
\text { situações o } \\
\text { efeito } \\
\text { fotoelétrico } \\
\text { é usado? }\end{array}$ & $\begin{array}{l}\text { Pergunta } \\
\text { de } \\
\text { sistematiz } \\
\text { ação. }\end{array}$ & \\
\hline 58 & $\begin{array}{l}\text { Prof.: Ah... você quer um exemplo técnico de onde é usado } \\
\text { isso... fotocélula, pra acender a lâmpada a noite, sensor de } \\
\text { elevador. }\end{array}$ & & & & \\
\hline 59 & Patrícia: Gera energia elétrica isso? & & & & previsão \\
\hline 60 & $\begin{array}{l}\text { Prof.: É, o que você fez, você provocou uma corrente elétrica } \\
\text { aqui. Bom. Então o que acontecia na virada do séc. XIX pro } \\
\text { séc. XX, os cientistas achavam que a gente já... os grandes } \\
\text { problemas da ciência já estavam resolvidos, e que existiam } \\
\text { alguns detalhes, algumas pequenas coisas que eram questão } \\
\text { de ajuste. Achava-se que, é... caminhava-se pro conhecimento } \\
\text { completo, mas aí tinham dois "pequenos" problemas, reparem } \\
\text { que pequenos está entre aspas, não são tão pequenos assim, } \\
\text { que era a questão das ondas eletromagnéticas, pois não Luis. } \\
\text { E eu vi que você tava conversando com ela. E uma outra } \\
\text { situação que acontecia era a questão do espectro de radiação, } \\
\text { e a relação entre espectro de radiação e temperatura, }\end{array}$ & & & & \\
\hline
\end{tabular}




\begin{tabular}{|l|l|l|l|l|}
\hline & $\begin{array}{l}\text { lembrando que naquele tempo a industria de base principal, era } \\
\text { a indústria siderúrgica, metalúrgica e aí o que aconteceu, } \\
\text { observava-se lá quando is colocar um metal pra fundir que } \\
\text { esse metal tinha radiação, certo? E aí começa a surgir então a } \\
\text { partir... oi }\end{array}$ & & & \\
\hline 61 & Patrícia: O que é aquilo? & & \\
\hline
\end{tabular}

\section{Momento 3 - Investigando situações clássicas (luz sob ação da gravidade, interferência, efeito fotoelétrico, reflexão) para aplicar um modelo explicativo.}

\begin{tabular}{|c|c|c|c|c|c|}
\hline $\mathrm{T}$ & Falas transcritas & Descrição & \begin{tabular}{|l|} 
Reformula \\
ndo a \\
pergunta. \\
\end{tabular} & $\begin{array}{l}\text { Classifica } \\
\text { ção }\end{array}$ & $\begin{array}{l}\text { Indicador de } \\
\text { AC }\end{array}$ \\
\hline 62 & $\begin{array}{l}\text { Prof.: Ah... aquilo é só foto da época. Tudo bem? Então a } \\
\text { mecânica quântica vai surgir a partir, a mecânica quântica } \\
\text { então começa a surgir a partir dessa, do estudo dessa } \\
\text { radiação quando os corpos eram aquecidos. Um físico } \\
\text { chamado Max Planck vai conseguir determinar qual é... vai } \\
\text { chegar matematicamente à observação dessa curva dos } \\
\text { espectros de radiação e aí vem o que a gente já discutiu um } \\
\text { pouquinho nas ultimas aulas a questão de ser... de que os } \\
\text { valores de energia são discretos, dependem da constante de } \\
\text { Planck e tal... bom, mas voltemos a nossa questão primeira, } \\
\text { lá de fevereiro, que afinal é a luz. Continua a pergunta, é } \\
\text { onda ou é partícula? (12) }\end{array}$ & $\begin{array}{l}\text { Refaz a } \\
\text { pergunta } \\
\text { central da } \\
\text { investigação }\end{array}$ & $\begin{array}{l}\text { A luz é onda } \\
\text { ou } \\
\text { partícula? }\end{array}$ & $\begin{array}{l}\text { Perguntas } \\
\text { de } \\
\text { problemati } \\
\text { zação }\end{array}$ & \\
\hline 63 & Patrícia: Não dá pra ser as duas? & & & & $\begin{array}{l}\text { Levantamento } \\
\text { de hipóteses }\end{array}$ \\
\hline 64 & Prof.: Ãh? & & & & \\
\hline 65 & Patrícia: Não dá pra ser as duas? & & & & $\begin{array}{l}\text { Levantamento } \\
\text { de hipóteses }\end{array}$ \\
\hline 66 & $\begin{array}{l}\text { Prof.: Calma, pra gente discutir isso, se dá ou não pra saber a } \\
\text { gente vai pensar em quatro situações. }\end{array}$ & & & & \\
\hline 67 & $\begin{array}{l}\text { Gilberto: Professor a luz não pode ser partícula com } \\
\text { propriedades de onda? }\end{array}$ & & & & $\begin{array}{l}\text { Levantamento } \\
\text { de hipóteses }\end{array}$ \\
\hline 68 & Prof.: Guarda essa sua pergunta pra gente discutir. & & & & \\
\hline 69 & Eduardo: Qual a pergunta dele? & & & & \\
\hline 70 & $\begin{array}{l}\text { Prof.: Ele tá dizendo assim, olha uma partícula pode ter } \\
\text { propriedades de onda? }\end{array}$ & & & & \\
\hline 71 & Eduardo: $E$ isso que eu to pensando, uma bolinha, sabe? & & & & $\begin{array}{l}\text { Levantamento } \\
\text { de hipóteses }\end{array}$ \\
\hline 72 & Prof.: Guarda essa sua representação também. & & & & \\
\hline 73 & $\begin{array}{l}\text { Gilberto: Eu tava conversando que pode ser uma onda com } \\
\text { propriedade de partícula, uma partícula com propriedade de } \\
\text { onda. }\end{array}$ & & & & $\begin{array}{l}\text { Levantamento } \\
\text { de hipótese }\end{array}$ \\
\hline 74 & $\begin{array}{l}\text { Gilberto.: Anota, vamos discutir isso. Mas antes da gente } \\
\text { chegar a essa discussão vamos pensar em quatro situações } \\
\text { relacionadas a luz e vamos tentar então responder a essas } \\
\text { situações pensando na luz como onda ou como partícula. A } \\
\text { primeira situação então, a gente pensa em uma luz emitida } \\
\text { por uma fonte que ta se propagando no espaço, se a luz for } \\
\text { uma onda ela se espalha pelo espaço, certo? Se a gente } \\
\text { pensar num feixe de luz e esse feixe de luz for partícula } \\
\text { imaginemos então... o Gilberto você quer falar coma sala? } \\
\text { Então se a gente pensar na luz como sendo onda ela vai se } \\
\text { espalhar pelo espaço, se a gente pensar num feixe de luz e } \\
\text { essa luz... é como sendo partícula, supondo que a gente aqui } \\
\text { na sala emitisse um raio de luz paralelo a tangente aqui, } \\
\text { paralelo ao nosso chão, o que vai acontecer com esse feixe }\end{array}$ & $\begin{array}{l}\text { Problematiza } \\
\text { uma situação } \\
\text { hipotética } \\
\text { para que os } \\
\text { alunos criem } \\
\text { hipóteses } \\
\text { sobre como a } \\
\text { luz se } \\
\text { comportaria } \\
\text { em uma dada } \\
\text { situação se } \\
\text { ela fosse } \\
\text { partícula. }\end{array}$ & \begin{tabular}{|l} 
Se \\
emitirmos \\
um raio de \\
luz reto o \\
que \\
acontecerá \\
com ele se \\
ele for \\
partícula?
\end{tabular} & $\begin{array}{l}\text { Pergunta } \\
\text { de } \\
\text { problemati } \\
\text { zação }\end{array}$ & \\
\hline
\end{tabular}




\begin{tabular}{|c|c|c|c|c|c|}
\hline & $\begin{array}{l}\text { de luz se ele for partícula?(13) Guilherme acorda por favor! E } \\
\text { aí? O que deve acontecer? }\end{array}$ & & & & \\
\hline 75 & Av:[inaudível] & & & & \\
\hline 76 & $\begin{array}{l}\text { Prof.: Se eu jogar uma bolinha daqui pro final da sala o que } \\
\text { vai acontecer? }\end{array}$ & $\begin{array}{l}\text { Criou uma } \\
\text { relação } \\
\text { concreta para } \\
\text { o problema } \\
\text { levantado }\end{array}$ & $\begin{array}{l}\text { Se eu jogar } \\
\text { uma bolinha } \\
\text { reta daqui } \\
\text { para o fim } \\
\text { da sala o } \\
\text { que } \\
\text { acontecerá } \\
\text { com ela? }\end{array}$ & $\begin{array}{l}\text { Pergunta } \\
\text { de } \\
\text { problemati } \\
\text { zação }\end{array}$ & \\
\hline 78 & Gilberto:Ela vai descrever.. & & & & \\
\hline 79 & Ptof.: Vai descrever... & & & & \\
\hline 80 & Gilberto: Uma parábola. & & & & Previsão \\
\hline 81 & Prof.: Por que?(15) & $\begin{array}{l}\text { Busca uma } \\
\text { explicação } \\
\text { para a } \\
\text { hipótese } \\
\text { levantada }\end{array}$ & $\begin{array}{l}\text { Por que a } \\
\text { bolinha vai } \\
\text { cair? }\end{array}$ & $\begin{array}{l}\text { Pergunta } \\
\text { de } \\
\text { sistematiz } \\
\text { ação }\end{array}$ & \\
\hline 82 & Gilberto: Porque você jogou e uma hora ela vai cair. & & & & justificativa \\
\hline 83 & Prof.: Por que?(16) & $\begin{array}{l}\text { Busca uma } \\
\text { explicação } \\
\text { para a } \\
\text { hipótese } \\
\text { levantada }\end{array}$ & $\begin{array}{l}\text { Por que a } \\
\text { bolinha vai } \\
\text { cair? }\end{array}$ & $\begin{array}{l}\text { Pergunta } \\
\text { de } \\
\text { sistematiz } \\
\text { ação }\end{array}$ & \\
\hline 84 & Gilberto:Por causa da gravidade. & & & & explicação \\
\hline 85 & $\begin{array}{l}\text { Prof.:Vai sofrer a ação da gravidade. Então se a luz for uma } \\
\text { partícula vai sofrer a ação da gravidade. }\end{array}$ & $\begin{array}{l}\text { Valida a } \\
\text { resposta do } \\
\text { aluno. }\end{array}$ & & & \\
\hline 86 & Gilberto: Professor e se a luz for tão rápida assim... & & & & \\
\hline 87 & $\begin{array}{l}\text { Prof.: } 300.000 \mathrm{~km} / \mathrm{s} \text { por exemplo. O que vai acontecer? O que } \\
\text { deveria acontecer? }\end{array}$ & $\begin{array}{l}\text { Contando que } \\
\text { a luz seja } \\
\text { uma partícula } \\
\text { se movando a } \\
\text { essa } \\
\text { velocidade o } \\
\text { que vai } \\
\text { acontecer } \\
\text { com os } \\
\text { efeitos } \\
\text { gravitacionais }\end{array}$ & $\begin{array}{l}\text { Como seria } \\
\text { a ação da } \\
\text { gravidade } \\
\text { em uma } \\
\text { bolinha com } \\
\text { a } \\
\text { velocidade } \\
\text { de } \\
300.000 \mathrm{~km} / \\
\mathrm{s} ?\end{array}$ & $\begin{array}{l}\text { Perguntas } \\
\text { exploratóri } \\
\text { as sobre o } \\
\text { processo. }\end{array}$ & \\
\hline 88 & Ademar: Uma hora ela vai perder velocidade. & & & & $\begin{array}{l}\text { Levantamento } \\
\text { de hipótese }\end{array}$ \\
\hline 89 & $\begin{array}{l}\text { Prof.: Não, só se tiver resistência. Mas mesmo assim não } \\
\text { tem, ela ta no espaço. Fora da atmosfera. O que vai } \\
\text { acontecer? Posso pensar numa situação semelhante ao } \\
\text { movimento da Lua em torno da Terra? O que vai acontecer } \\
\text { com a luz?(18) Vai ficar em órbita não é isso? Mas se eu } \\
\text { pegar um trecho pequeno o que vai acontecer? Eu jogo daqui } \\
\text { to mirando aqui na cabeça dela, vai cair a onda? (19) }\end{array}$ & & $\begin{array}{l}\text { Para uma } \\
\text { pequena } \\
\text { distância o } \\
\text { que } \\
\text { acontece } \\
\text { com os } \\
\text { efeitos da } \\
\text { gravidade } \\
\text { em uma } \\
\text { partícula } \\
\text { com a } \\
\text { velocidade } \\
\text { de } \\
300.000 \mathrm{~km} / \\
\text { s? }\end{array}$ & $\begin{array}{l}\text { Perguntas } \\
\text { exploratóri } \\
\text { as sobre o } \\
\text { processo. }\end{array}$ & \\
\hline 90 & A30 (não identificado): Na cabeça dela. & & & & previsão \\
\hline 91 & Prof.: Não. Vai cair exatamente onde eu mirei? & & & $\begin{array}{l}\text { Perguntas } \\
\text { exploratóri } \\
\text { as sobre o } \\
\text { processo. }\end{array}$ & \\
\hline 92 & A30 (não identificado): Não & & & & Previsão. \\
\hline 93 & $\begin{array}{l}\text { Prof.: Tem a ação da gravidade vai cair um pouquinho né? } \\
\text { Então e mais ou menos isso essa primeira situação. Vamos } \\
\text { pensar então que a gente tem uma distancia de } 5 \mathrm{~m} \text { da } \\
\text { televisão até a prateleira e a gente emite então uma fonte de }\end{array}$ & & & & \\
\hline
\end{tabular}




\begin{tabular}{|c|c|c|c|c|c|}
\hline & luz daqui até a parede. Fala Julia. & & & & \\
\hline 94 & $\begin{array}{l}\text { Patrícia: Quando você vai atirar em alguém você tem que } \\
\text { mirar um pouco mais pra cima pra acertar. }\end{array}$ & & & & \\
\hline 95 & Prof.: A mira já faz isso. & & & & \\
\hline 96 & Patrícia: A é? A tá... & & & & \\
\hline 97 & $\begin{array}{l}\text { Prof.: A mira fica acima do cano, ela já ta prevendo isso aí. } \\
\text { Ma voltemos, o nosso tiro é de luz só. }\end{array}$ & & & & \\
\hline 98 & Av:[inaudível] & & & & \\
\hline 99 & 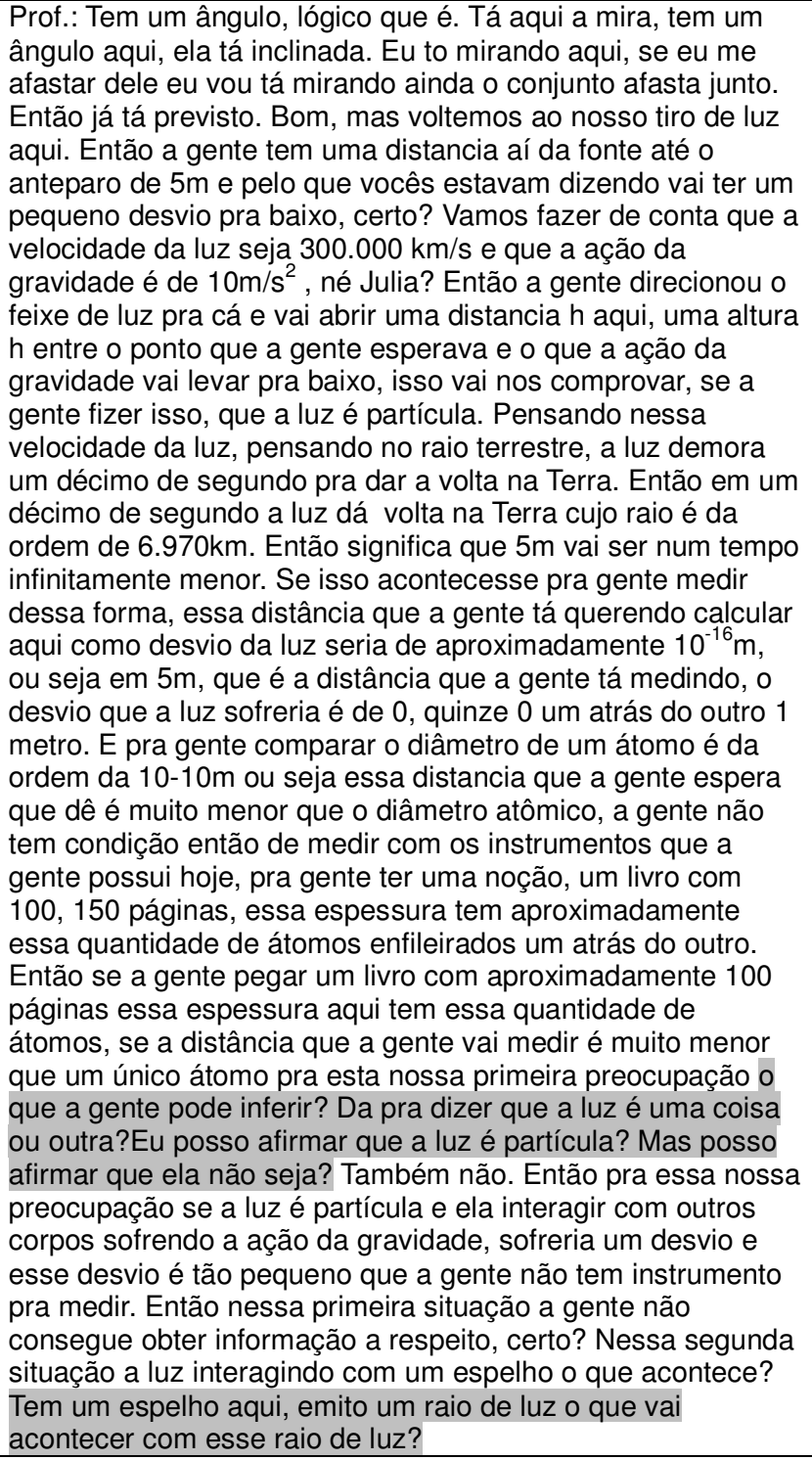 & $\begin{array}{l}\text { Dada a } \\
\text { suposição da } \\
\text { situação 1. } \\
\text { Não é } \\
\text { possível } \\
\text { medir por isso } \\
\text { não se pode } \\
\text { afirmar nem } \\
\text { uma coisa } \\
\text { nem outra. O } \\
\text { professor } \\
\text { explora a } \\
\text { situação } \\
\text { hipotética } \\
\text { fazendo os } \\
\text { alunos } \\
\text { pensarem } \\
\text { sobre as } \\
\text { possíveis } \\
\text { explicações } \\
\\
\text { Para a } \\
\text { segunda } \\
\text { proposta, ele } \\
\text { coloca a } \\
\text { situação } \\
\text { sobre algo } \\
\text { que os alunos } \\
\text { já viram. }\end{array}$ & $\begin{array}{l}\text { Posto que } \\
\text { não } \\
\text { podemos } \\
\text { medir a } \\
\text { queda da } \\
\text { luz pela } \\
\text { atração } \\
\text { gravitaciona } \\
\text { l, podemos } \\
\text { afirmar que } \\
\text { ela é } \\
\text { partícula? } \\
\text { Podemos } \\
\text { afirmar que } \\
\text { ela não é? } \\
\\
\text { O que } \\
\text { acontece } \\
\text { com a luz } \\
\text { emitida em } \\
\text { um } \\
\text { espelho? }\end{array}$ & $\begin{array}{l}\text { Perguntas } \\
\text { exploratóri } \\
\text { as sobre } \\
\text { processo. }\end{array}$ & \\
\hline 100 & Eduardo: Vai ser refletido. & & & & $\begin{array}{l}\text { Previsão/ } \\
\text { explicação }\end{array}$ \\
\hline 101 & $\begin{array}{l}\text { Prof.: Vai ser refletido. Qual é a condição de reflexão?(25) } \\
\text { Tem que voltar no mesmo ângulo que incidiu, não é isso? } \\
\text { Então a condição é manda um raio de luz pro espelho volta } \\
\text { no mesmo ângulo, não é isso? E aí pra essa situação eu } \\
\text { posso responder se a luz for partícula a partícula bate no } \\
\text { espelho e é refletida, se a luz for onda bate no espelho e } \\
\text { também é refletida. A que conclusão a gente chega?(26) }\end{array}$ & $\begin{array}{l}\text { Busca uma } \\
\text { resposta de } \\
\text { um conceito. } \\
\text { Expõe a } \\
\text { situação em } \\
\text { que a luz } \\
\text { pode ser as } \\
\text { duas coisas } \\
\text { (onda e } \\
\text { partícula) } \\
\text { pede uma } \\
\text { conclusão }\end{array}$ & $\begin{array}{l}\text { Qual a lei } \\
\text { da reflexão? } \\
\text { Se a luz } \\
\text { como onda } \\
\text { bate no } \\
\text { espelho e } \\
\text { reflete e a } \\
\text { luz como } \\
\text { uma } \\
\text { partícula } \\
\text { bate no } \\
\text { espelho e } \\
\text { também } \\
\text { reflete, qual }\end{array}$ & $\begin{array}{l}\text { Pergunta } \\
\text { de } \\
\text { sistematiz } \\
\text { ação } \\
\text { Pergunta } \\
\text { de } \\
\text { sistematiz } \\
\text { ação }\end{array}$ & \\
\hline
\end{tabular}




\begin{tabular}{|c|c|c|c|c|c|}
\hline & & & $\begin{array}{l}\text { a } \\
\text { conclusão? }\end{array}$ & & \\
\hline 102 & Cristina: Nenhuma. & & & & \\
\hline 103 & $\begin{array}{l}\text { Prof.: Pode ser onda ou partícula, certo? Terceira situação, } \\
\text { agora eu tenho uma luz emitida por uma fonte que atravessa } \\
\text { um anteparo que tem duas fendas, então vamos pensar } \\
\text { numa chapinha, essa chapinha tem dois cortes, né, duas } \\
\text { fendas e aí algo semelhante a isso aqui, certo? Então a gente } \\
\text { tem um anteparo com duas fendas e a gente faz incidir sobre } \\
\text { ele uma fonte de luz. O que vai acontecer? O que acontece? } \\
\text { Aqui é uma fenda aqui é outra fenda, mesma fonte de luz, } \\
\text { passa por aqui e aí o que vai acontecer? Se a luz bater aqui } \\
\text { [na parte que não há fenda] o que acontece? }\end{array}$ & $\begin{array}{l}\text { Problema da } \\
\text { fenda. O que } \\
\text { acontecerá } \\
\text { na situação } \\
\text { tres. Os } \\
\text { elementos } \\
\text { para } \\
\text { responder a } \\
\text { questão não } \\
\text { são evidentes } \\
\\
\text { Exemplificou } \\
\text { a questão. } \\
\text { Para } \\
\text { direcionar o } \\
\text { olhar dos } \\
\text { alunos a } \\
\text { descartar } \\
\text { variáveis }\end{array}$ & $\begin{array}{l}\text { O que } \\
\text { acontece } \\
\text { quando } \\
\text { incidimos } \\
\text { uma luz em } \\
\text { duas } \\
\text { fendas? } \\
\text { O que } \\
\text { acontece } \\
\text { quando a } \\
\text { luz bate em } \\
\text { um objeto } \\
\text { opaco? }\end{array}$ & $\begin{array}{l}\text { Pergunta } \\
\text { de } \\
\text { problemati } \\
\text { zação }\end{array}$ & \\
\hline 104 & Nicolau: Ela passa. & & & & $\begin{array}{l}\text { Previsão/ } \\
\text { explicação }\end{array}$ \\
\hline 105 & Prof.: Passa? & ? & & & \\
\hline 106 & Nicolau: Bate e volta. & & & & explicação \\
\hline 107 & $\begin{array}{l}\text { Prof.:Bate e volta se o objeto for opaco, é isso? Se bate aqui } \\
\text { [no vão da fenda]?(28) }\end{array}$ & idem & $\begin{array}{l}\text { O que } \\
\text { acontece } \\
\text { quando a } \\
\text { luz passa } \\
\text { por uma } \\
\text { fenda? }\end{array}$ & $\begin{array}{l}\text { Perguntas } \\
\text { de } \\
\text { sistematiz } \\
\text { ação }\end{array}$ & \\
\hline 108 & Nicolau: Passa. & & & & explicação \\
\hline 109 & $\begin{array}{l}\text { Prof.: Passa, vai ficar aqui assim, certo? Se bate aqui [no vão } \\
\text { da outra fenda]? Passa também, eu vou ter outra linha aqui, } \\
\text { certo? Posso ter um pequeno desvio pra um lado ou pro outro } \\
\text { dependendo do ângulo de incidência, não é isso? Aqui então } \\
\text { deve ser sombra, não deve ter marca nenhuma, não é isso? } \\
\text { Aquela região vai ser uma região de sombra. }\end{array}$ & idem & $\begin{array}{l}\text { O que } \\
\text { acontece } \\
\text { quando a } \\
\text { luz passa } \\
\text { por uma } \\
\text { fenda? } \\
\end{array}$ & $\begin{array}{l}\text { Perguntas } \\
\text { de } \\
\text { sistematiz } \\
\text { ação }\end{array}$ & \\
\hline 110 & Augusto: Só se a luz não estiver muito inclinada. & & & & explicação \\
\hline 111 & $\begin{array}{l}\text { Prof.: Mas se estiver muito inclinado, pensando que muita } \\
\text { inclinação tá vindo muito pra cá o que vai acontecer, eu vou } \\
\text { continuar com esse padrão você concorda? Eu vou ter.. isso } \\
\text { vem mais pra cá e isso desloca mais pra cá, mas a gente } \\
\text { espera que tenha um intervalo aqui, não é isso? Então se a } \\
\text { luz for partícula é isso que acontece, certo? Só que o que a } \\
\text { gente observa, agora vou ter que apagar aqui um pouquinho, } \\
\text { então esse é o nosso experimento, a gente tem uma fonte de } \\
\text { luz aqui, tem as duas fendas, e aí a gente tem alguma coisa } \\
\text { parecida com isso aqui se ela for partícula, certo? Mas a } \\
\text { gente observa algo parecido com isso aqui quando a gente } \\
\text { faz a luz passar por um anteparo com dupla fenda. A gente } \\
\text { conversou agora pouco que aqui no meio não deveria } \\
\text { acontecer nada, uma região sombra, que não haveria nada } \\
\text { ali, então no anteparo atrás naquela região ali não deveria ter } \\
\text { nada. }\end{array}$ & & & & \\
\hline 112 & A36 (não identificado): Se for partícula. & & & & $\begin{array}{l}\text { Levantamento } \\
\text { de hipótese }\end{array}$ \\
\hline 113 & $\begin{array}{l}\text { Prof.: Se for partícula. Mas a gente observa nesse ponto aqui, } \\
\text { que é esse ponto aqui, a gente observa a presença de linhas } \\
\text { ali, e aí a gente não consegue explicar isso como partícula, } \\
\text { agora como onda a gente consegue explicar através de que } \\
\text { fenômeno? }\end{array}$ & $\begin{array}{l}\text { Com a figura } \\
\text { dada de } \\
\text { interferência } \\
\text { pergunta qual } \\
\text { fenomeno } \\
\text { pode explicar } \\
\text { aquilo. Um } \\
\text { conceito já } \\
\text { visto. }\end{array}$ & $\begin{array}{l}\text { Qual } \\
\text { fenomeno } \\
\text { que explica } \\
\text { uma figura } \\
\text { desta? }\end{array}$ & $\begin{array}{l}\text { Pergunta } \\
\text { de } \\
\text { sistematiz } \\
\text { ação }\end{array}$ & \\
\hline 114 & Av:[inaudível] & & & & \\
\hline
\end{tabular}




\begin{tabular}{|c|c|c|c|c|c|}
\hline 115 & Prof.: Mais que isso.. vão chutar todos? & & & & \\
\hline 116 & Alice: Interferência & & & & explicação \\
\hline 117 & $\begin{array}{l}\text { Prof.: Interferência. Lembram disso? A gente pode ter } \\
\text { interferência construtiva ou destrutiva, e aí quando a } \\
\text { interferência é construtiva vai aparecer e quando é negativa } \\
\text { as ondas se anulam. A gente observa... foi isso aqui que a } \\
\text { gente viu quando a gente fez a observação aqui na parede, } \\
\text { que a gente colocou um feixe de luz passando por uma rede } \\
\text { de difração e aí o que a gente observou foram esses pontos } \\
\text { aqui, isso aqui é foto tirada aqui na sala de aula. Bom, com } \\
\text { essa terceira observação o que a gente conclui até agora? }\end{array}$ & $\begin{array}{l}\text { Unindo a } \\
\text { observação } \\
\text { de qua a luz } \\
\text { se comporta } \\
\text { como onda } \\
\text { em uma } \\
\text { dupla fenda o } \\
\text { professor } \\
\text { quer que os } \\
\text { alunos } \\
\text { conluam por } \\
\text { hora que a } \\
\text { luz é onda } \\
\end{array}$ & $\begin{array}{l}\text { Se nesta } \\
\text { montagem } \\
\text { a luz } \\
\text { apresenteu } \\
\text { uma } \\
\text { natureza de } \\
\text { onda, o que } \\
\text { podemos } \\
\text { concluir até } \\
\text { agora? }\end{array}$ & $\begin{array}{l}\text { Pergunta } \\
\text { de } \\
\text { sistematiz } \\
\text { ação }\end{array}$ & \\
\hline 118 & Av:[inaudível] & & & & \\
\hline 119 & Prof.: Nessa situação eu só posso concluir que a luz é... & & & & \\
\hline 120 & Av: Onda & & & & explicação \\
\hline 121 & $\begin{array}{l}\text { Prof.: Onda. As duas primeiras posso explicar como onda ou } \\
\text { como partícula, aqui eu só consigo... }\end{array}$ & & & & \\
\hline 122 & Alice: O quarto só consegue explicar como partícula. & & & & previsão \\
\hline 123 & $\begin{array}{l}\text { Prof.: É evidente Alice? Aí segundo a Alice o quarto a gente } \\
\text { só consegue explicar como partícula é isso Alice? Por que eu } \\
\text { só posso explicar o efeito fotoelétrico como sendo partícula? }\end{array}$ & $\begin{array}{l}\text { Tenta buscar } \\
\text { dos alunos } \\
\text { um modelo } \\
\text { que explique } \\
\text { o efeito } \\
\text { fotoelétrico } \\
\text { com a luz } \\
\text { sendo } \\
\text { partícula }\end{array}$ & $\begin{array}{l}\text { Porque eu } \\
\text { só consigo } \\
\text { explicar o } \\
\text { Efot com a } \\
\text { luz sendo } \\
\text { partícula? }\end{array}$ & $\begin{array}{l}\text { Pergunta } \\
\text { de } \\
\text { problemati } \\
\text { zação. }\end{array}$ & \\
\hline 124 & Augusto: Porque arranca elétrons. & & & & $\begin{array}{l}\text { Levantamento } \\
\text { de hipótese }\end{array}$ \\
\hline 125 & $\begin{array}{l}\text { Prof:: Mas arrancar elétrons eu posso arrancar como sendo } \\
\text { onda. }\end{array}$ & & & & \\
\hline 126 & Rubens: Não & & & & \\
\hline 127 & $\begin{array}{l}\text { Prof.: Por que não?Uma onda vem transfere energia, a gente } \\
\text { não disse que uma onda transporta energia? Ela transfere } \\
\text { energia pro elétron, o elétron recebe energia e é emitido. } \\
\text { Posso explicar como onda, não posso? }\end{array}$ & & & & $\begin{array}{l}\text { Teste de } \\
\text { hipótese }\end{array}$ \\
\hline 128 & Rubens:[inaudível] & & & & \\
\hline 129 & $\begin{array}{l}\text { Prof.: Quando eu falo em efeito fotoelétrico a gente tá falando } \\
\text { assim efeito fotoelétrico é quando eu faço incidir numa placa } \\
\text { metálica luz, e aí elétrons são arrancados dessa placa. Essa } \\
\text { luz que ta incidindo eu poso explicar como onda?(34) A onda } \\
\text { pode interagir com a matéria? Pode. Tá transportando } \\
\text { energia? Tá. E por que a gente fala então que o efeito } \\
\text { fotoelétrico só pode ser explicado se a luz for partícula?(36) }\end{array}$ & $\begin{array}{l}\text { Refaz a } \\
\text { pergunta } \\
\text { problema de } \\
\text { forma mais } \\
\text { explicativa } \\
\\
\\
\text { Refaz o } \\
\text { problema já } \\
\text { dizendo que a } \\
\text { interação } \\
\text { como onda é } \\
\text { possível. } \\
\text { Necessita-se } \\
\text { de uma } \\
\text { hipótese. }\end{array}$ & $\begin{array}{l}\text { Posso dizer } \\
\text { que a luz } \\
\text { que retira } \\
\text { eletrons da } \\
\text { placa } \\
\text { metálica } \\
\text { age como } \\
\text { uma onda? } \\
\text { Se luz é } \\
\text { energia e a } \\
\text { energia } \\
\text { pode } \\
\text { interagir } \\
\text { com a } \\
\text { matéria por } \\
\text { que } \\
\text { explicamos } \\
\text { o Efot com } \\
\text { a luz sendo } \\
\text { partícula? } \\
\end{array}$ & $\begin{array}{l}\text { Pergunta } \\
\text { exploratóri } \\
\text { a de } \\
\text { processo. }\end{array}$ & \\
\hline 130 & A42 (não identificado): [inaudível] & & & & \\
\hline 131 & $\begin{array}{l}\text { Prof.: Não, mas transporta energia e a energia tá interagindo } \\
\text { com a matéria. Então o que tá acontecendo? Fala aí Clara. } \\
\text { Qual é sua explicação pra isso. Vamos pensar juntos. O que } \\
\text { a mecânica clássica previa pra questão da onda, ta certo? } \\
\text { Então olha, eu tenho a luz arrancando elétrons de uma } \\
\text { superfície metálica, certo? E aí o que a gente esperava? }\end{array}$ & $\begin{array}{l}\text { Retoma a } \\
\text { simulação } \\
\text { para verificar } \\
\text { as } \\
\text { possibilidades } \\
\text { da luz ser } \\
\end{array}$ & $\begin{array}{l}\text { Esperávam } \\
\text { os jogar } \\
\text { uma luz } \\
\text { com maior } \\
\text { intensidade } \\
\text { e ter um } \\
\end{array}$ & $\begin{array}{l}\text { Perguntas } \\
\text { sobre } \\
\text { dados }\end{array}$ & \\
\hline
\end{tabular}




\begin{tabular}{|c|c|c|c|c|c|}
\hline & $\begin{array}{l}\text { Quanto mais intensa for a luz maior a velocidade do elétron } \\
\text { emitido, ou seja quanto maior for a intensidade da luz maior a } \\
\text { energia do elétron que tá saindo. Isso acontece? }\end{array}$ & $\begin{array}{l}\text { onda ou } \\
\text { partícula no } \\
\text { Efot. }\end{array}$ & $\begin{array}{l}\text { eletron com } \\
\text { maior } \\
\text { intensidade, } \\
\text { isso } \\
\text { aconteceu? }\end{array}$ & & \\
\hline 132 & Av: Não & & & & $\begin{array}{l}\text { Organização de } \\
\text { informações }\end{array}$ \\
\hline 133 & Prof.: O que a gente viu lá na simulação, o que acontecia? & & $\begin{array}{l}\text { O que } \\
\text { observamos } \\
\text { na } \\
\text { simulação } \\
\text { quando } \\
\text { aumentamo } \\
\text { s a } \\
\text { intensidade } \\
\text { da luz? }\end{array}$ & $\begin{array}{l}\text { Pergunta } \\
\text { sobre } \\
\text { dados. }\end{array}$ & \\
\hline 134 & A43: Dependia da freqüência da luz. & & & & $\begin{array}{l}\text { Organização de } \\
\text { informações. }\end{array}$ \\
\hline 135 & $\begin{array}{l}\text { Prof.: Não, mas com relação a intensidade. O que acontecia } \\
\text { lá com os elétrons que ficavam correndo, que chegavam na } \\
\text { plaquinha de chegada. }\end{array}$ & & & & \\
\hline 136 & Luis: [inaudível] & & & & \\
\hline 137 & $\begin{array}{l}\text { Prof.: Não, quando aumentava a intensidade o que } \\
\text { acontecia? }\end{array}$ & $\begin{array}{l}\text { Refaz a } \\
\text { pergunta }\end{array}$ & $\begin{array}{l}\text { O que } \\
\text { observamos } \\
\text { na } \\
\text { simulação } \\
\text { quando } \\
\text { aumentamo } \\
\text { s a } \\
\text { intensidade } \\
\text { da luz? }\end{array}$ & $\begin{array}{l}\text { Pergunta } \\
\text { sobre } \\
\text { dados. }\end{array}$ & \\
\hline 138 & Nicolau: não acontecia nada. & & & & $\begin{array}{l}\text { Organização de } \\
\text { informações. }\end{array}$ \\
\hline 139 & Prof.: O que mudava? & $\begin{array}{l}\text { Refina a } \\
\text { pergunta para } \\
\text { uma } \\
\text { espcificidade } \\
\text { da simulação }\end{array}$ & $\begin{array}{l}\text { O que } \\
\text { mudava nos } \\
\text { eletrons } \\
\text { quando } \\
\text { almentávam } \\
\text { os a } \\
\text { intensidade } \\
\text { da luz? } \\
\end{array}$ & $\begin{array}{l}\text { Pergunta } \\
\text { sobre } \\
\text { dados. }\end{array}$ & \\
\hline 140 & Nicolau: Nada. & & & & $\begin{array}{l}\text { Organização de } \\
\text { informações. }\end{array}$ \\
\hline 141 & Eduardo: [inaudível] & & & & \\
\hline 142 & $\begin{array}{l}\text { Prof.: Não, isso é o eu era previsto. Mudava a velocidade, e } \\
\text { não muda, e o que a gente via lá, quando a gente mudou lá } \\
\text { na simulação o que aconteceu com os elétrons? }\end{array}$ & $\begin{array}{l}\text { Refaz a } \\
\text { pergunta } \\
\text { refinada }\end{array}$ & \begin{tabular}{|l} 
O que \\
mudava nos \\
eletrons \\
quando \\
almentávam \\
os a \\
intensidade \\
da luz? \\
\end{tabular} & $\begin{array}{l}\text { Pergunta } \\
\text { sobre } \\
\text { dados. }\end{array}$ & \\
\hline 143 & Educardo: Eles não chegavam mais lá & & & & $\begin{array}{l}\text { Organização de } \\
\text { informações. }\end{array}$ \\
\hline 144 & Prof.: Não, os que conseguiam chegar. & & & & \\
\hline 145 & Eduardo: la mais rápido. & & & & \\
\hline 146 & $\begin{array}{l}\text { Prof.: Não, ia mais rápido era o previsto. Se eu aumento a } \\
\text { intensidade da luz o que acontece? Fala. O que acontece } \\
\text { classe? }\end{array}$ & $\begin{array}{l}\text { Refaz a } \\
\text { pergunta } \\
\text { novamente }\end{array}$ & $\begin{array}{l}\text { O que } \\
\text { mudava nos } \\
\text { eletrons } \\
\text { quando } \\
\text { aumentáva } \\
\text { mos a } \\
\text { intensidade } \\
\text { da luz? } \\
\end{array}$ & $\begin{array}{l}\text { Pergunta } \\
\text { sobre } \\
\text { dados. }\end{array}$ & \\
\hline 147 & A46 (não identificado): [inaudível] & & & & \\
\hline 148 & $\begin{array}{l}\text { Prof.: Não, a intensidade é pra falar se é mais forte ou mais } \\
\text { fraco. }\end{array}$ & & & & \\
\hline 149 & Cristina: O número de elétrons? & & & & \\
\hline
\end{tabular}




\begin{tabular}{|c|c|c|c|c|c|}
\hline 150 & $\begin{array}{l}\text { Prof.: O numero de elétrons? A quantidade. Então olha, o } \\
\text { esperado era assim, eu aumento a intensidade, aumenta a } \\
\text { energia cinética do elétron emitido. Isso é o que era previsto, } \\
\text { no entanto o que acontece de fato, eu aumento a intensidade } \\
\text { e tenho mais elétrons, lembrando lá da simulação o elétron } \\
\text { tava correndo e chegava lá na linha de chegada e quando a } \\
\text { gente aumentava a intensidade mais elétrons chegavam, mas } \\
\text { eles chegavam juntos, não era num tempo menor, certo? } \\
\text { Segunda coisa, o que era esperado quando a gente tivesse } \\
\text { uma intensidade baixa? }\end{array}$ & $\begin{array}{l}\text { Retoma as } \\
\text { relações da } \\
\text { simulação } \\
\text { sobre o } \\
\text { esperado e o } \\
\text { obtido }\end{array}$ & $\begin{array}{l}\text { O que } \\
\text { esperávamo } \\
\text { s quando a } \\
\text { luz incidida } \\
\text { na placa } \\
\text { metálica } \\
\text { fosse de } \\
\text { baixa } \\
\text { intensidade } \\
?\end{array}$ & $\begin{array}{l}\text { Pergunta } \\
\text { exploratóri } \\
\text { a sobre o } \\
\text { processo. }\end{array}$ & \\
\hline 151 & Eduardo: Que não emitiria. & & & & $\begin{array}{l}\text { Organização de } \\
\text { informações. }\end{array}$ \\
\hline 152 & $\begin{array}{l}\text { Prof.: Não. Eu tenho energia suficiente pra arrancar, só que a } \\
\text { intensidade da luz é baixa, o que a gente esperava? Que ele } \\
\text { ia ficar um tempo antes de ser emitido, porque ele precisava } \\
\text { armazenar essa energia. Então quando a gente mandasse } \\
\text { uma luz com intensidade fraca o elétron ia precisar de um } \\
\text { tempo, nesse tempo ele ia estar absorvendo até que essa } \\
\text { energia fosse suficiente pra ele ser arrancado, certo? } \\
\text { Acontece isso? O que a gente viu quando fez a simulação? }\end{array}$ & $\begin{array}{l}\text { Refina a } \\
\text { pergunta, } \\
\text { relação } \\
\text { causal } \\
\\
\text { Retoma a } \\
\text { simulação } \\
\text { para verificar } \\
\text { o que } \\
\text { aconteceu. }\end{array}$ & $\begin{array}{l}\text { Com a luz } \\
\text { emitida com } \\
\text { energia } \\
\text { suficiente } \\
\text { para } \\
\text { arrancar } \\
\text { eletrons } \\
\text { mas com } \\
\text { baixa } \\
\text { intensidade, } \\
\text { o que } \\
\text { esperávamo } \\
\text { s? } \\
\text { Nós } \\
\text { observamos } \\
\text { na } \\
\text { simulação } \\
\text { que o } \\
\text { eletron } \\
\text { espera um } \\
\text { tempo antes } \\
\text { de ser } \\
\text { emitido? }\end{array}$ & $\begin{array}{l}\text { Pergunta } \\
\text { exploratóri } \\
\text { a sobre o } \\
\text { processo. }\end{array}$ & \\
\hline 153 & Augusto: Os elétrons pegavam e já saiam. & & & & $\begin{array}{l}\text { Organização de } \\
\text { informações./ } \\
\text { previsão }\end{array}$ \\
\hline 154 & $\begin{array}{l}\text { Prof.: Isso, no exato momento em que você tinha a incidência } \\
\text { a emissão é instantânea, tá? Então, incidiu a luz emissão } \\
\text { instantânea, não teve esse tempo de espera. Vamos pensar } \\
\text { aqui então. Recapitulando, primeira previsão, maior } \\
\text { intensidade da luz, maior a energia do elétron emitido, o que } \\
\text { a gente observa, aumentou a intensidade, aumenta a } \\
\text { quantidade, mas a velocidade permaneça a mesma. Segunda } \\
\text { previsão, se a intensidade for fraca o que a gente vai } \\
\text { observar, nossa, se a intensidade for fraca deveria haver um } \\
\text { tempo até que os elétrons começassem a ser emitidos. Então } \\
\text { você coloca lá a luz incidindo na placa e vai esperar lá u } \\
\text { tempo até que haja a emissão. O que a gente observa de fato } \\
\text { é que independente da intensidade, se a energia for } \\
\text { suficiente o elétron é emitido imediatamente. Tem mais. O } \\
\text { que a gente percebeu lá também? A previsão dizia que de } \\
\text { veria acontecer pra qualquer freqüência de luz, e o que a } \\
\text { gente observou nas duas simulações? Era com qualquer uma } \\
\text { que a gente tinha elétrons arrancados? O que precisava } \\
\text { acontecer? }\end{array}$ & $\begin{array}{l}\text { Retoma a } \\
\text { observação } \\
\text { da simulação }\end{array}$ & $\begin{array}{l}\text { De acordo } \\
\text { com as } \\
\text { simulações, } \\
\text { era para } \\
\text { qualquer } \\
\text { frequencia } \\
\text { de luz que } \\
\text { arrancava } \\
\text { eletrons da } \\
\text { placa? }\end{array}$ & $\begin{array}{l}\text { Pergunta } \\
\text { de dados. }\end{array}$ & \\
\hline 155 & Cristina: [inaudível] & & & & \\
\hline 156 & Prof.: Tá associado a que? & & & & \\
\hline 157 & Cristina: $A$ freqüência. & & & & explicação \\
\hline 158 & $\begin{array}{l}\text { Prof.: Então eu tenho uma freqüência mínima pra isso } \\
\text { acontecer. Acontecia mais perto de que cores? }\end{array}$ & $\begin{array}{l}\text { Retomando } \\
\text { as } \\
\text { observações } \\
\text { do simulador }\end{array}$ & $\begin{array}{l}\text { Em que } \\
\text { região do } \\
\text { espectro de } \\
\text { cores a luz } \\
\text { incidida } \\
\text { fazia emitir } \\
\text { eletrons? }\end{array}$ & $\begin{array}{l}\text { Pergunta } \\
\text { sobre } \\
\text { dados }\end{array}$ & \\
\hline 159 & Av: Azul, vermelho. & & & & $\begin{array}{l}\text { Classificação } \\
\text { de informações }\end{array}$ \\
\hline
\end{tabular}




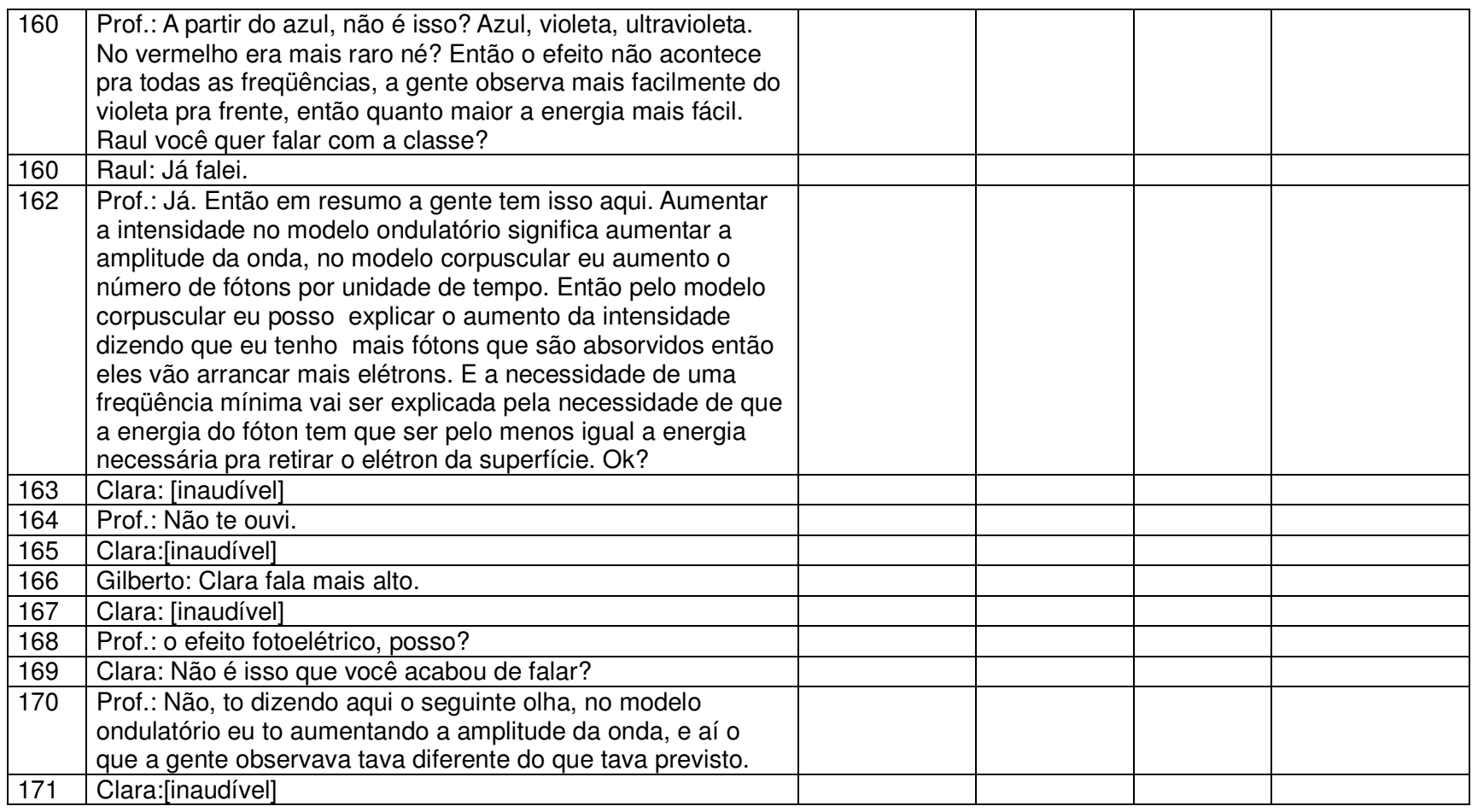

\section{Momento 4 - Problematização: Se as duas explicações clássicas não dão conta de explicar todos os fenomenos, o que deve ser a luz?}

\begin{tabular}{|c|c|c|c|c|c|}
\hline$T$ & Falas transcritas & Descrição & $\begin{array}{l}\text { Reformula } \\
\text { ndo a } \\
\text { pergunta. }\end{array}$ & $\begin{array}{l}\text { Classifica } \\
\text { ção }\end{array}$ & $\begin{array}{l}\text { Indicador de } \\
\text { AC }\end{array}$ \\
\hline 172 & $\begin{array}{l}\text { Prof.: corpuscular é partícula, corpúsculo, tá? Então o efeito } \\
\text { fotoelétrico explica a luz como sendo partícula. E aí vem } \\
\text { aquelas questões que vocês apresentaram no inicio aula, } \\
\text { vocês Eduardo e Luquinhas. E aí segundo o Gilberto, como } \\
\text { que era a previsão, a luz pode ser o que? }\end{array}$ & $\begin{array}{l}\text { Retoma o } \\
\text { problema }\end{array}$ & $\begin{array}{l}\text { Diante } \\
\text { destas } \\
\text { situações, a } \\
\text { luz pode ser } \\
\text { o que? }\end{array}$ & $\begin{array}{l}\text { Pergunta } \\
\text { de } \\
\text { problemati } \\
\text { zação }\end{array}$ & \\
\hline 173 & $\begin{array}{l}\text { Gilberto: Onda com propriedades de partícula ou partícula } \\
\text { com propriedades de onda. }\end{array}$ & & & & $\begin{array}{l}\text { Levantamento } \\
\text { de hipóteses }\end{array}$ \\
\hline 174 & $\begin{array}{l}\text { Prof.: E se segundo o modelo apresentado aqui pelo Eduardo } \\
\text { a gente tem oque? }\end{array}$ & $\begin{array}{l}\text { Explora } \\
\text { hipótese do } \\
\text { aluno com a } \\
\text { sala. }\end{array}$ & & & \\
\hline 175 & Eduardo:Uma bolinha vibrando. & & & & $\begin{array}{l}\text { Levantamento } \\
\text { de hipótese }\end{array}$ \\
\hline 176 & $\begin{array}{l}\text { Prof.: Uma bolinha vibrando, uma partícula vibrando. A } \\
\text { representação que ele tava trazendo era essa, certo? O que } \\
\text { nós vamos discutir. }\end{array}$ & & & & \\
\hline 177 & Augusto: O que você acha? & & & & \\
\hline 178 & $\begin{array}{l}\text { Prof.: Eu não acho nada. Gente, aqui tem um resumo então } \\
\text { dos fenômenos e das explicações, possíveis ou não, pra cada } \\
\text { um dos dois modelos. Então nesse quadrinho aqui a gente } \\
\text { tem, né... pra esses fenômenos. Olhando pra esse quadro, a } \\
\text { gente pode falar que a luz é uma onda? }\end{array}$ & $\begin{array}{l}\text { Resume as } \\
\text { situações } \\
\text { expressas } \\
\text { nas quais não } \\
\text { se explica } \\
\text { interiamente } \\
\text { todos os } \\
\text { casos com } \\
\text { nenhum dos } \\
\text { dois modelos. }\end{array}$ & $\begin{array}{l}\text { Observando } \\
\text { as } \\
\text { situações e } \\
\text { as } \\
\text { possibilidad } \\
\text { es de } \\
\text { explicar os } \\
\text { casos como } \\
\text { onda ou } \\
\text { partícula, } \\
\text { podemos } \\
\text { afirmar que } \\
\text { é uma }\end{array}$ & $\begin{array}{l}\text { Pergunta } \\
\text { de } \\
\text { sistematiz } \\
\text { ação }\end{array}$ & \\
\hline
\end{tabular}




\begin{tabular}{|c|c|c|c|c|c|}
\hline & & & onda? & & \\
\hline 179 & Diversos: Mais ou menos. & & & & explicação \\
\hline 180 & Diversos: Não. & & & & explicação \\
\hline 181 & Prof.: Posso dizer que é uma onda? Posso? & $\begin{array}{l}\text { Refaz a } \\
\text { pergunta }\end{array}$ & idem & $\begin{array}{l}\text { Pergunta } \\
\text { de } \\
\text { sistematiz } \\
\text { ação }\end{array}$ & \\
\hline 182 & Av: Não. & & & & explicação \\
\hline 183 & $\begin{array}{l}\text { Prof:: Se ela é onda ela explica tudo isso aqui, certo? Explica } \\
\text { aqui? Então pode ser onda? }\end{array}$ & & $\begin{array}{l}\text { Observando } \\
\text { as } \\
\text { situações e } \\
\text { as } \\
\text { possibilidad } \\
\text { es de } \\
\text { explicar os } \\
\text { casos como } \\
\text { onda ou } \\
\text { partícula, } \\
\text { podemos } \\
\text { afirmar que } \\
\text { é uma } \\
\text { onda? }\end{array}$ & & \\
\hline 184 & Diversos: Não. & & & & $\begin{array}{l}\text { Organização de } \\
\text { informações }\end{array}$ \\
\hline 185 & $\begin{array}{l}\text { Prof.: Porque não explica esse fenômeno. Olhando pra cá, } \\
\text { posso dizer que é partícula? }\end{array}$ & idem & $\begin{array}{l}\text { Observando } \\
\text { as } \\
\text { situações e } \\
\text { as } \\
\text { possibilidad } \\
\text { es de } \\
\text { explicar os } \\
\text { casos como } \\
\text { onda ou } \\
\text { partícula, } \\
\text { podemos } \\
\text { afirmar que } \\
\text { é uma } \\
\text { partícula? }\end{array}$ & $\begin{array}{l}\text { Pergunta } \\
\text { de } \\
\text { sistematiz } \\
\text { ação }\end{array}$ & \\
\hline 186 & Av: Não. & & & & $\begin{array}{l}\text { Organização de } \\
\text { informações }\end{array}$ \\
\hline 187 & $\begin{array}{l}\text { Prof.: Não explicou esses dois. Posso dizer que é os dois? } \\
\text { Essa é a discussão que a gente vai começar a fazer a partir } \\
\text { de agora. }\end{array}$ & idem & $\begin{array}{l}\text { Observando } \\
\text { as } \\
\text { situações e } \\
\text { as } \\
\text { possibilidad } \\
\text { es de } \\
\text { explicar os } \\
\text { casos como } \\
\text { onda ou } \\
\text { partícula, } \\
\text { podemos } \\
\text { afirmar que } \\
\text { é os dois? }\end{array}$ & $\begin{array}{l}\text { Pergunta } \\
\text { de } \\
\text { problemati } \\
\text { zação }\end{array}$ & \\
\hline 188 & Av: [inaudível] & & & & \\
\hline 189 & $\begin{array}{l}\text { Prof.: Porque assim, se os dois modelos que a gente tem } \\
\text { explicam parte dos fenômenos, e esses dois modelos são } \\
\text { excludentes. Eu posso dizer que é as duas coisas? }\end{array}$ & $\begin{array}{l}\text { Reforça a } \\
\text { conclusão da } \\
\text { aula de que } \\
\text { não se pode } \\
\text { explicar os } \\
\text { casos com } \\
\text { somente um } \\
\text { modelo, nem } \\
\text { com os dois. }\end{array}$ & $\begin{array}{l}\text { Observando } \\
\text { as } \\
\text { situações e } \\
\text { as } \\
\text { possibilidad } \\
\text { es de } \\
\text { explicar os } \\
\text { casos como } \\
\text { onda ou } \\
\text { partícula, } \\
\text { podemos } \\
\text { afirmar que } \\
\text { é uma } \\
\text { partícula? }\end{array}$ & $\begin{array}{l}\text { Pergunta } \\
\text { de } \\
\text { problemati } \\
\text { zação }\end{array}$ & \\
\hline 190 & Teresa: Em determinada situação... & & & & Levantamento \\
\hline
\end{tabular}




\begin{tabular}{|c|c|c|c|c|c|}
\hline & & & & & de hipóteses \\
\hline 191 & Augusto: É intermediário. & & & & $\begin{array}{l}\text { Levantamento } \\
\text { de hipóteses }\end{array}$ \\
\hline 192 & $\begin{array}{l}\text { Prof.: Uma terceira coisa? Lembrando desde o inicio lá, nossa } \\
\text { primeira discussão sobre modelo, onda e partícula são } \\
\text { excludentes. Onda tá espalhada, partícula ta localizada, } \\
\text { certo? Começa por aí, algo pode estar ao meso tempo bem } \\
\text { localizado e espalhado? Dá pra ser ao mesmo tempo as duas } \\
\text { coisas? }\end{array}$ & $\begin{array}{l}\text { Reforça a } \\
\text { conclusão } \\
\text { colocando o } \\
\text { fator do } \\
\text { tempo e as } \\
\text { característica } \\
\text { s dos objetos } \\
\text { físicos onda e } \\
\text { partícula. } \\
\text { Problematiza } \\
\text { ndo. }\end{array}$ & $\begin{array}{l}\text { Se a luz } \\
\text { está } \\
\text { espalhada } \\
\text { no espaço e } \\
\text { a partícula } \\
\text { está bem } \\
\text { localizada, } \\
\text { algo pode } \\
\text { estar ao } \\
\text { mesmo } \\
\text { tempo } \\
\text { espalhado e } \\
\text { localizado? } \\
\end{array}$ & $\begin{array}{l}\text { Pergunta } \\
\text { de } \\
\text { problemati } \\
\text { zação }\end{array}$ & \\
\hline 193 & Patrícia: Depende. & & & & $\begin{array}{l}\text { Levantamento } \\
\text { de hipótese }\end{array}$ \\
\hline 194 & $\begin{array}{l}\text { Prof.: Depende né? O que a gente tem até agora é isso aqui, } \\
\text { interferência eu só consigo explicar como onda, efeito } \\
\text { fotoelétrico só consigo como partícula... }\end{array}$ & & & & \\
\hline 195 & Gilberto: A luz não poderia ser uma exceção? & & & $\begin{array}{l}\text { Pergunta } \\
\text { de } \\
\text { problemati } \\
\text { zação }\end{array}$ & $\begin{array}{l}\text { Levantamento } \\
\text { de hipótese }\end{array}$ \\
\hline 196 & $\begin{array}{l}\text { Prof.: Poderia? Vamos tentar discutir juntos a luz na mecânica } \\
\text { quântica, certo? }\end{array}$ & & & & \\
\hline 197 & Rubens: Deixa a luz como luz e já era. & & & & \\
\hline 198 & $\begin{array}{l}\text { Prof.: Luz é luz e ponto né? Mas não pode ser assim. Bom } \\
\text { gente, se sobrar tempo... }\end{array}$ & & & & \\
\hline 199 & Alice: Já vai tocar. & & & & \\
\hline 200 & Prof.: Não, nós temos 5min. & & & & \\
\hline 201 & Alice: $1 \mathrm{~min}$. & & & & \\
\hline 202 & $\begin{array}{l}\text { Prof.: Tá bom gente, então em 1min esses são os } \\
\text { fenômenos, reflexão, refração, difração, interferência, } \\
\text { polarização e dispersão. E a gente tem que responder com } \\
\text { base nas teorias corpuscular e ondulatória. Reparem, teoria } \\
\text { corpuscular a luz é constituída por partículas ou corpúsculos } \\
\text { que se movem em alta velocidade em linha reta. Teoria } \\
\text { ondulatória, a luz é uma onda que se propaga do mesmo } \\
\text { modo que a onda sonora, ou uma onda... e aí vocês têm três } \\
\text { grandes cientistas que discutiram a natureza da luz, certo? } \\
\text { Primeiro fenômeno, o galera, então olha, pra esse fenômeno, } \\
\text { reflexão da luz que é o que... Quando a luz volta pro meio na } \\
\text { qual ela tava se propagando, bate no anteparo e volta pro } \\
\text { mesmo meio. Na teoria corpuscular... }\end{array}$ & $\begin{array}{l}\text { Resume a } \\
\text { aula e } \\
\text { anuncia e } \\
\text { explica o } \\
\text { exercício. }\end{array}$ & & & \\
\hline
\end{tabular}




\section{1 - Introdução da aula, retoma os componentes do interferômetro, as figuras de interferência observadas e relembra o problema}

\begin{tabular}{|c|c|c|c|c|c|}
\hline $\mathbf{T}$ & Falas transcritas & Descrição & $\begin{array}{l}\text { Reformulando a } \\
\text { pergunta. }\end{array}$ & Classificação & $\begin{array}{l}\text { INDICADO } \\
\text { RES DE } \\
\text { AC }\end{array}$ \\
\hline 001 & Gilberto: Professor. & & & & \\
\hline 002 & $\begin{array}{l}\text { Professor: Mais alguém não me entregou ainda a atividade } \\
\text { da última aula? Bom pessoal, presta atenção. Vocês tão } \\
\text { recebendo uma folhinha e a gente vai agora tentar sintetizar } \\
\text { as discussões que a fez ao longo do ano e tentar interpretar } \\
\text { um pouquinho o que ta acontecendo de fato, ta? Pra isso a } \\
\text { gente vai continuar explorando o nosso interferômetro, } \\
\text { certo? Pra isso nós vamos combinar o seguinte, nós vamos } \\
\text { tentar fazer dessa forma, vocês viram que eu tirei aí do } \\
\text { campinho, não é avaliação, ta certo? Não é prova, nem } \\
\text { nada, é apenas um questionário que a gente vai tentar } \\
\text { então sintetizar as ideias. A gente vai tentar fazer da } \\
\text { seguinte maneira, a gente vai começar a discutir e a } \\
\text { medida que a discussão for avançando, eu vou dando um } \\
\text { tempinho pra que vocês respondam, preencham o quadro, } \\
\text { ta? E aí no finalzinho da aula as três ultimas questões, ta } \\
\text { legal? Se não tiver dando certo isso, a gente faz toda a } \\
\text { discussão e depois a gente completa a atividade. Não é pra } \\
\text { copiar o que ta... O que vai aparecer no quadro, porque se } \\
\text { não, não faz sentido. A gente vai conversar sobre e depois } \\
\text { eu tiro da tela e a gente conversa, ta? Bom, na aula } \\
\text { passada, nessa aula de hoje a gente começou a discutir um } \\
\text { pouquinho o que a gente viu no interferômetro real e o que } \\
\text { a gente viu na simulação. A gente vai explorar um } \\
\text { pouquinho mais esse nosso interferômetro. Aí eu separei } \\
\text { um pouquinho algumas imagens do nosso interferômetro. } \\
\text { Então, já ta identificado. Então, os semiespelhos, que na } \\
\text { verdade são vidros, né? A gente pode imaginar o } \\
\text { semiespelho como sendo quando a gente olha pela janela } \\
\text { ao entardecer ou então quando a gente olha pela manhã a } \\
\text { gente, às vezes a gente enxerga nosso reflexo no espelho, } \\
\text { mas também a gente enxerga o que ta lá do outro lado, ta? } \\
\text { Tudo bem? Então, os dois semiespelhos e os dois } \\
\text { espelhos. Foi esse o arranjo que a gente tem. Agora tem aí } \\
\text { a imagem do que a gente... Ta bom, se fechar tudo fica } \\
\text { muito escuro e a gente não consegue ver. Bom, aí eu } \\
\text { separei então duas imagens, uma do interferômetro real e a } \\
\text { outra do simulador, certo? Foi isso que a gente observou, } \\
\text { certo? Foi isso que você viu, Clara? }\end{array}$ & $\begin{array}{l}\text { Mostando a } \\
\text { figura de } \\
\text { inrferêcia } \\
\text { confere a } \\
\text { visualização } \\
\text { dos alunos }\end{array}$ & $\begin{array}{l}\text { Foi esta figura de } \\
\text { interferência que } \\
\text { observamos quando } \\
\text { fizemos o } \\
\text { experimento? }\end{array}$ & $\begin{array}{l}\text { Pergunta sobre } \\
\text { dados }\end{array}$ & \\
\hline 003 & Alice: Não. & & & & \\
\hline 004 & $\begin{array}{l}\text { Professor: Alguém enxergou uma figura parecida com essa } \\
\text { do real? }\end{array}$ & $\begin{array}{l}\text { Verificando se } \\
\text { houve } \\
\text { semelhança } \\
\text { entre o } \\
\text { observado e a } \\
\text { figura exposta }\end{array}$ & $\begin{array}{l}\text { Alguém observou } \\
\text { esta figura de } \\
\text { interferência na } \\
\text { montagem? }\end{array}$ & $\begin{array}{l}\text { Pergunta sobre } \\
\text { dados }\end{array}$ & \\
\hline 005 & Priscila: Não. & & & & \\
\hline 006 & Professor: Ninguém? & & & & \\
\hline
\end{tabular}




\begin{tabular}{|c|c|c|c|c|c|}
\hline $\mathbf{T}$ & Falas transcritas & Descrição & $\begin{array}{c}\text { Reformulando a } \\
\text { pergunta. }\end{array}$ & Classificação & $\begin{array}{l}\text { INDICADO } \\
\text { RES DE } \\
\text { AC }\end{array}$ \\
\hline 007 & Alunos: Não. & & & & \\
\hline 008 & $\begin{array}{l}\text { Professor: Nem naquela outra experiência que a gente } \\
\text { usou só um laser e um tecido como rede de difração? }\end{array}$ & $\begin{array}{l}\text { Refina a } \\
\text { pergunta } \\
\text { expecificando } \\
\text { a experiência }\end{array}$ & $\begin{array}{l}\text { Vocês enxergaram } \\
\text { essa figura de } \\
\text { interferência na } \\
\text { experienciência com } \\
\text { o laser e o tecido? }\end{array}$ & $\begin{array}{l}\text { Pergunta sobre } \\
\text { dados }\end{array}$ & \\
\hline 009 & Lúcia: Sim... Eu. & & & & \\
\hline 010 & $\begin{array}{l}\text { Professor: Que a gente projetou lá na parede ou no } \\
\text { quadro? (03:55) }\end{array}$ & & & & \\
\hline 011 & Breton: Era assim, desse jeito & & & & $\begin{array}{l}\text { Seriaçã } \\
0\end{array}$ \\
\hline 012 & $\begin{array}{l}\text { Professor: Era assim que tava? Ah, tirei. Não, é que eu ia } \\
\text { apresentar pra vocês tinha uma outra imagem. Fala, } \\
\text { Breton. }\end{array}$ & & & & \\
\hline 013 & Breton: Era tipo... Um monte. Um monte não, não sei... & & & & $\begin{array}{l}\text { Organiz } \\
\text { ação }\end{array}$ \\
\hline 014 & Professor: Uma do lado da outra, não é isso? & & & & \\
\hline 015 & Breton: É. & & & & \\
\hline 016 & $\begin{array}{l}\text { Professor: É que eu tirei a foto daqui agora, ta no outro } \\
\text { computador. A outra possibilidade, tinha uma outra foto, ao } \\
\text { invés da gente enxergar dessa forma, a gente enxergava } \\
\text { mais ou menos isso aqui, como disse o Nicolau (04:31) } \\
\text { Também a gente tinha essa observação...(?) Bom, aí lá na } \\
\text { nossa experiência, pedi pra que vocês identificassem. Era } \\
\text { essa identificação que a gente tinha. E foi pedido pra vocês } \\
\text { desenharem aí como é que era o caminho que tava sendo } \\
\text { percorrido pela luz. E aí a simulação mostrava pra vocês } \\
\text { como duas frentes de onda, certo? Aí a pergunta feita, não } \\
\text { ta no textinho, não ta no roteiro, a gente colocou um } \\
\text { anteparo aqui, certo? Se a gente colocasse o anteparo } \\
\text { aqui, deste outro lado, o que a gente deveria ver? Qual a } \\
\text { relação com essas duas figuras? }\end{array}$ & $\begin{array}{l}\text { Retomando a } \\
\text { atividade da } \\
\text { aula anterior, } \\
\text { traça as } \\
\text { relções da luz } \\
\text { quando se } \\
\text { colocava um } \\
\text { anteparo. }\end{array}$ & $\begin{array}{l}\text { Quando mudamos a } \\
\text { posição do anteparo } \\
\text { para o outro lado } \\
\text { (aqui) o que } \\
\text { observávamos? }\end{array}$ & $\begin{array}{l}\text { Pergunta sobre } \\
\text { dados }\end{array}$ & \\
\hline 017 & Márcia: (05:38) Complementar & & & & $\begin{array}{l}\text { Classifi } \\
\text { cação }\end{array}$ \\
\hline 018 & Professor: Como assim? & & & & \\
\hline 019 & $\begin{array}{l}\text { Márcia: }(05: 41) \text { Por exemplo, seria assim, numa o centro } \\
\text { seria claro e teria as listras e na outra é ao contrário, o } \\
\text { centro preto e as listras ao contrário. }\end{array}$ & & & & $\begin{array}{l}\text { Levanta } \\
\text { mento } \\
\text { de } \\
\text { hipótes } \\
\text { es }\end{array}$ \\
\hline 020 & $\begin{array}{l}\text { Professor: Como que é, Eduardo? Fala alto pra classe } \\
\text { ouvir. }\end{array}$ & & & & \\
\hline 021 & $\begin{array}{l}\text { Eduardo: Se a gente colocasse o anteparo aqui e não aqui, } \\
\text { seria o inverso do que a gente viu. }\end{array}$ & & & & $\begin{array}{l}\text { Levanta } \\
\text { mento } \\
\text { de } \\
\text { hipótes } \\
\text { es }\end{array}$ \\
\hline 022 & Alunos como assim? [inaudível] & & & & \\
\hline 023 & Eduardo:: seria o inverso do que a gente viu & & & & \\
\hline 024 & $\begin{array}{l}\text { Professor: Todo mundo acha que é isso? Todo mundo acha } \\
\text { que é a mesma coisa? E alguém sabe explicar por quê? } \\
\text { Então olha, vamos imaginar... O que vocês tão me dizendo } \\
\text { é isso, num anteparo a gente observa alguma coisa } \\
\text { parecida com isso, certo? No outro, a gente vai enxergar o } \\
\text { contrário, não é isso? [mostra uma folha e gesticula, } \\
\text { apontando as diferenças] Elas seriam complementares } \\
\text { porque se a gente juntasse as figuras, veria o quê? (07:20) }\end{array}$ & $\begin{array}{l}\text { Constroi uma } \\
\text { ideia de } \\
\text { complementari } \\
\text { dade com as } \\
\text { figuras de } \\
\text { interferência. } \\
\text { Complementari } \\
\text { dade como } \\
\text { aquelas que se } \\
\text { complementam }\end{array}$ & $\begin{array}{l}\text { O que veriamos se } \\
\text { juntássemos as duas } \\
\text { figuras? }\end{array}$ & $\begin{array}{l}\text { Perguntas } \\
\text { sobre dados }\end{array}$ & \\
\hline
\end{tabular}




\begin{tabular}{|c|c|c|c|c|c|}
\hline $\mathbf{T}$ & Falas transcritas & Descrição & $\begin{array}{c}\text { Reformulando a } \\
\text { pergunta. }\end{array}$ & Classificação & $\begin{array}{l}\text { INDICADO } \\
\text { RES DE } \\
\text { AC } \\
\end{array}$ \\
\hline 025 & Nicolau: Um círculo & & & & $\begin{array}{l}\text { Levanta } \\
\text { mento } \\
\text { de } \\
\text { hipótes } \\
\text { es }\end{array}$ \\
\hline 026 & $\begin{array}{l}\text { Professor: É isso. Ao invés de ver várias figuras, veria um } \\
\text { círculo. Aí, agora a pergunta... Joe! Alguém consegue me } \\
\text { explicar porque isso? [inaudível] Mas por quê? Dá pra } \\
\text { explicar por quê? }\end{array}$ & $\begin{array}{l}\text { Tenta buscar } \\
\text { as cusas da } \\
\text { inversão de } \\
\text { linhas de } \\
\text { interferência } \\
\text { com a } \\
\text { mudança do } \\
\text { anteparo }\end{array}$ & $\begin{array}{l}\text { Como conseguimos } \\
\text { explicar a mudança } \\
\text { das franjas de } \\
\text { interferência quando } \\
\text { mudamos o } \\
\text { anteparo? }\end{array}$ & $\begin{array}{l}\text { Pergunta de } \\
\text { problematizaçã } \\
0\end{array}$ & \\
\hline 027 & $\begin{array}{l}\text { Nicolau: [inaudível] Eu consigo explicar o que é, mas } \\
\text { porquê eu não sei. }\end{array}$ & & & & $\begin{array}{l}\text { O.E.: } \\
\text { Definiç } \\
\text { ão }\end{array}$ \\
\hline 028 & $\begin{array}{l}\text { Professor: Não, nós não chegamos neste ponto ainda. } \\
\text { [refere-se à explicação do que é o fenômeno] (07:57) }\end{array}$ & & & & \\
\hline 029 & $\begin{array}{l}\text { Gilberto: [quase inaudível, tentando explicar o que está } \\
\text { acontecendo] é igual aquela experiência que a gente batia } \\
\text { o dedo na água e fazia umas ondas, elas se aumentavam, } \\
\text { aumentava não, elas ficavam juntas [entrelaça os dedos } \\
\text { das mãos] só que eu esqueci o nome do fenômeno }\end{array}$ & & & & $\begin{array}{l}\text { Justific } \\
\text { ativa } \\
\text { O.E.: } \\
\text { Apelo a } \\
\text { exempl } \\
\text { o }\end{array}$ \\
\hline 030 & Professor: interferência de ondas? & & & & \\
\hline 031 & Gilberto: É, acho que é. Só que faz mile e anos, tá ligado. & & & & \\
\hline
\end{tabular}

\section{2 - Exploração do fenômeno de interferência da experiência tanto para a luz quanto para o fótons individuais comparando as figuras formadas.}

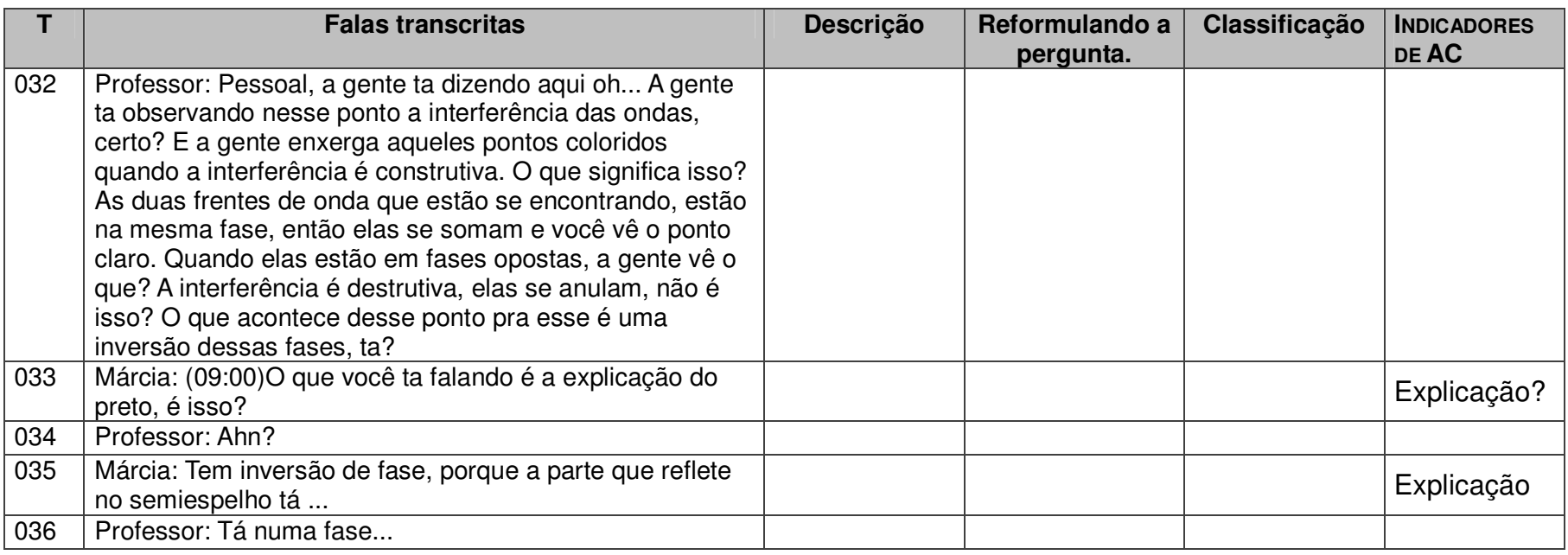




\begin{tabular}{|c|c|c|c|c|c|}
\hline 037 & $\begin{array}{l}\text { Márcia: numa fase diferente da que parte que passou } \\
\text { direto }\end{array}$ & & & & $\begin{array}{l}\text { Explicação } \\
\text { O.E.: } \\
\text { plausibilidad } \\
\text { e }\end{array}$ \\
\hline 038 & $\begin{array}{l}\text { Professor: Isso. E aí o que vai ta acontecendo? Vamos } \\
\text { supor que a fase } 1 \text { ta vindo pra cá e a } 2 \text { pra cá, certo? } \\
\text { [mostra no quadro] Nesse caso aqui, eu vou pegar a } 1 \\
\text { deste, né? E vai interferir com a outra que ta aqui, não é } \\
\text { isso? Então o que ta acontecendo é que ela ta pegando } \\
\text { os lados simétricos, tudo bem? Bom, aí a gente mudou } \\
\text { pra fóton, como vocês bem responderam na ultima aula, o } \\
\text { que acontece com o padrão da figura? O resultado. }\end{array}$ & $\begin{array}{l}\text { Lembrando o } \\
\text { procedimento } \\
\text { da experiência } \\
\text { o professor } \\
\text { retoma o que } \\
\text { acontece com } \\
\text { fotons } \\
\text { individuais no } \\
\text { interferômetro }\end{array}$ & $\begin{array}{l}\text { Quando } \\
\text { emitiamos fotóns } \\
\text { no interferômetro } \\
\text { qual a } \\
\text { observação que } \\
\text { faziamos? }\end{array}$ & $\begin{array}{l}\text { Pergunta sobre } \\
\text { dados }\end{array}$ & \\
\hline 039 & Gilberto: (10:00) Igual, mas pontinhos & & & & $\begin{array}{l}\text { Classificaçã } \\
\text { O } \\
\text { O.E.: } \\
\text { classificação }\end{array}$ \\
\hline 040 & $\begin{array}{l}\text { Professor: É o mesmo, não é? O que ta acontecendo só é } \\
\text { que a gente aqui vai... Quando a gente manda com o } \\
\text { laser forma imagem instantaneamente, não é isso? Todo o } \\
\text { fóton... Ele vai se distribuindo, né? E dependendo da } \\
\text { quantidade que a gente tem aí a gente vai acabar } \\
\text { observando a linha, certo? Até aqui nenhuma novidade, } \\
\text { né? Tudo bem aí, Guilherme? Explica essas duas figuras } \\
\text { aí pra mim, por favor. Fala aí, Willian. }\end{array}$ & & & & \\
\hline 041 & Willian: O canto de lá é... & & & & \\
\hline 042 & $\begin{array}{l}\text { Professor: O canto de lá você diz a direita de quem ta } \\
\text { olhando? }\end{array}$ & & & & \\
\hline 043 & Willian: Isso... Não, a esquerda de quem ta olhando. & & & & \\
\hline 044 & Alunos: Inaudível & & & & \\
\hline 045 & Professor: Vamos chamar esse de 1 e esse de 2. & & & & \\
\hline 046 & Willian: Ta. O 2 é de fóton e o de cá onda & & & & $\begin{array}{l}\text { Levantamen } \\
\text { to de } \\
\text { hipótese }\end{array}$ \\
\hline 047 & Professor: O que eles têm de semelhante? & $\begin{array}{l}\text { Compara as } \\
\text { duas figuras de } \\
\text { interferência } \\
\text { com luz e } \\
\text { fotons }\end{array}$ & $\begin{array}{l}\text { Qual a } \\
\text { semelhança } \\
\text { entre os dois } \\
\text { resultados } \\
\text { (imagens)? }\end{array}$ & $\begin{array}{l}\text { Pergunta sobre } \\
\text { dados }\end{array}$ & \\
\hline 048 & Willian: $\mathrm{O}$ desenho... & & & & $\begin{array}{l}\text { Organização } \\
\text { O.E. } \\
\text { Indução }\end{array}$ \\
\hline 049 & Professor: A imagem? Ta... E o que vai ter de diferente? & $\begin{array}{l}\text { Compara as } \\
\text { duas figuras de } \\
\text { interferência } \\
\text { com luz e } \\
\text { fotons }\end{array}$ & $\begin{array}{l}\text { Qual a diferença } \\
\text { entre estes dois } \\
\text { resultados(image } \\
\text { ns) }\end{array}$ & $\begin{array}{l}\text { Pergunta sobre } \\
\text { dados }\end{array}$ & \\
\hline 050 & Willian: É como se forma. & & & & $\begin{array}{l}\text { Classificaçã } \\
\text { O } \\
\text { O.E.: } \\
\text { Causalidade }\end{array}$ \\
\hline 051 & Professor: É o que? & & & & \\
\hline 052 & $\begin{array}{l}\text { Gilberto: Gradativamente, professor, conforme os fótons } \\
\text { vão chegando. (11:25) }\end{array}$ & & & & $\begin{array}{l}\text { Teste de } \\
\text { hipótese } \\
\text { O.E.: } \\
\text { Causalidade }\end{array}$ \\
\hline 053 & $\begin{array}{l}\text { Professor: dessa maneira [aponta para uma das imagens], } \\
\text { a formação, ela é instantânea, né? E nessa aqui [aponta a } \\
\text { outra imagem] ele vai se formando conforme vai } \\
\text { acontecendo a chegada das partículas. }\end{array}$ & & & & \\
\hline 054 & Gilberto: No laser os fótons estão todos juntinhos? & & & & $\begin{array}{l}\text { Levantamen } \\
\text { to de } \\
\text { hipótese } \\
\text { O.E.: } \\
\text { Causalidade }\end{array}$ \\
\hline
\end{tabular}




\begin{tabular}{|c|c|c|c|c|c|}
\hline 055 & $\begin{array}{l}\text { Professor: Não, laser a gente tem que pensar na luz } \\
\text { sendo onda. Na verdade, ora como onda, ora como } \\
\text { partícula. Bom, e aqui? Alice S, compare essas duas } \\
\text { figuras. }\end{array}$ & & & & \\
\hline 056 & $\begin{array}{l}\text { Alice: Na primeira, são circunferências concêntricas e na } \\
\text { segunda são conjuntos de pontinhos... }\end{array}$ & & & & $\begin{array}{l}\text { Previsão } \\
\text { O.E.: } \\
\text { definição }\end{array}$ \\
\hline 057 & Professor: E? Por quê? & & & & \\
\hline 060 & Alice: Porque na primeira tem interferência. & & & & $\begin{array}{l}\text { Explicação } \\
\text { O.E.: } \\
\text { definição }\end{array}$ \\
\hline 064 & $\begin{array}{l}\text { Gilberto: Então, nos primeiros círculos as duas se } \\
\text { encontram, os dois raios estão juntos (12:37) }\end{array}$ & & & & $\begin{array}{l}\text { Explicação } \\
\text { O.E.: } \\
\text { plausibilidad } \\
\text { e }\end{array}$ \\
\hline 065 & Professor: Pessoal! & & & & \\
\hline 066 & $\begin{array}{l}\text { Gilberto: Enquanto que na outra figura como tem um } \\
\text { detector ele impede a passagem de um dos caminhos de } \\
\text { chegar no anteparo, então só tem um caminho que o } \\
\text { fóton pode passar. Por isso, ele não forma a figura. } \\
(12: 52)\end{array}$ & & & & $\begin{array}{l}\text { Explicação } \\
\text { O.E. } \\
\text { plausibilidad } \\
\text { e }\end{array}$ \\
\hline 067 & $\begin{array}{l}\text { Professor: Tá. Então, nesse caso, não tem interferência e } \\
\text { aqui] a gente tem interferência, não é isso? Bom, agora o } \\
\text { seguinte, o que a gente veio conversando ao longo do } \\
\text { ano inteirinho é que a física pode explicar as coisas de } \\
\text { duas maneiras, ou como onda ou como partícula. }\end{array}$ & & & & \\
\hline
\end{tabular}

\section{3 - O problema da intereferência para um único foton no interferômetro. Diante da figura de interferência para fótons individuais, o professor delimita bem a contradição entre haver interferência do elétron com ele mesmo.}




\begin{tabular}{|c|c|c|c|c|c|}
\hline $\mathbf{T}$ & Falas transcritas & Descrição & $\begin{array}{l}\text { Reformulando } \\
\text { a pergunta. }\end{array}$ & Classificação & $\begin{array}{l}\text { INDICADORES } \\
\text { DE AC }\end{array}$ \\
\hline 069 & $\begin{array}{l}\text { Professor: Não, as coisas, no geral. Pra luz, em particular, } \\
\text { nós chegamos numa encruzilhada. Nós chegamos numa } \\
\text { encruzilhada agora A Clara, se eu não me engano na aula } \\
\text { passada, no finalzinho da aula, colocou exatamente qual } \\
\text { era o nosso problema. Como é que eu explico, se eu } \\
\text { pensar que a luz é uma partícula e o fóton é uma } \\
\text { partícula, como é que eu explico a interferência pra um } \\
\text { único fóton? Então, é isso que a mecânica quântica vai } \\
\text { tentar conversar com a gente }\end{array}$ & $\begin{array}{l}\text { Problematiza a } \\
\text { explicação da } \\
\text { interferência } \\
\text { para um foton } \\
\text { único. }\end{array}$ & $\begin{array}{l}\text { Como eu } \\
\text { explico o } \\
\text { fenomeno da } \\
\text { interferência } \\
\text { para um único } \\
\text { fóton }\end{array}$ & $\begin{array}{l}\text { Pergunta de } \\
\text { problematização. }\end{array}$ & \\
\hline 070 & Eduardo: (14:22) explicar como eles passam & & & & \\
\hline 071 & $\begin{array}{l}\text { Professor: Não, um único. Como é que um fóton interfere } \\
\text { com ele mesmo. [inaudível, vários alunos falam ao } \\
\text { mesmo tempo] Não, não, peraí. Pessoal, diferente do que } \\
\text { eles tão dizendo aqui, não é quando a gente tem assim, } \\
\text { ah, eu tenho a luz interagindo com outra coisa, aí você ta } \\
\text { aumentando as variáveis. Nós estamos pensando assim, } \\
\text { olha... Foi isso que a Clara discutiu aqui na ultima aula. } \\
\text { Como é que eu explico interferência para um único fóton? } \\
\text { Ele com ele mesmo. Na nossa figurinha lá, se eu lançar } \\
\text { apenas um único fóton, entendeu? Diferente do que a } \\
\text { gente tinha no real, que a gente manda um feixe, a gente } \\
\text { ta mandando milhões ao mesmo tempo e aí eu posso } \\
\text { continuar pensando em bolinhas colidindo uma com a } \\
\text { outra, né? Agora não, eu tenho um único E nesse único } \\
\text { eu continuo tendo interferência. }\end{array}$ & & & & \\
\hline 072 & Alice: Ele se dividiu ao meio. & & & & $\begin{array}{l}\text { Levantamen } \\
\text { to de } \\
\text { hipótese }\end{array}$ \\
\hline 073 & $\begin{array}{l}\text { Professor: Quando ele passa lá no semiespelho ele se } \\
\text { divide em duas partes? }\end{array}$ & & & & \\
\hline 074 & Alice: É... & & & & \\
\hline 075 & $\begin{array}{l}\text { Professor: Mas duas partes do que? De partícula? Duas } \\
\text { partes de onda? Uma parte partícula outra parte onda? }\end{array}$ & $\begin{array}{l}\text { Para hipótese } \\
\text { do foton se } \\
\text { dividir em duas } \\
\text { partes o } \\
\text { professor } \\
\text { explora quais } \\
\text { seriam as } \\
\text { partes desta } \\
\text { divisão. } \\
\end{array}$ & $\begin{array}{l}\text { Se o fóton se } \\
\text { dividiu em duas } \\
\text { partes, o que } \\
\text { compõe essas } \\
\text { duas partes? } \\
\text { Particula? } \\
\text { Onda? As duas } \\
\text { coisas? }\end{array}$ & $\begin{array}{l}\text { Pergunta de } \\
\text { problematização }\end{array}$ & \\
\hline 076 & Alice: Acho que as duas partes partícula. & & & & $\begin{array}{l}\text { Levantamen } \\
\text { to de } \\
\text { hipótese }\end{array}$ \\
\hline 077 & $\begin{array}{l}\text { Professor: Mas aí se ele se dividir ao meio, eu deixo de } \\
\text { ter um fóton e tenho dois. Dois meio fótons... }\end{array}$ & & & & \\
\hline 078 & Alice: Aí depois eles se juntam. & & & & $\begin{array}{l}\text { Levantamen } \\
\text { to de } \\
\text { hipótese }\end{array}$ \\
\hline 079 & Professor: Junta aqui embaixo de novo? & & & & \\
\hline 080 & Alice: $\dot{E}$, os dois lados. & & & & Previsão \\
\hline 081 & $\begin{array}{l}\text { Professor: mas como é que com eles juntos eu posso ter } \\
\text { no anteparo dos dois lados? Aqui... Olha, a Clara ta } \\
\text { dizendo o seguinte, aqui ele se divide, certo? Aí vem pra } \\
\text { cá e vem pra cá. Quando chega aqui, se eles se juntam, } \\
\text { como a Clara ta falando, eu teria que ter observação em } \\
\text { um único anteparo, mas eu consigo medir nos dois ao } \\
\text { mesmo tempo. }\end{array}$ & $\begin{array}{l}\text { Motiva uma } \\
\text { hipótese para a } \\
\text { explicação do } \\
\text { foton se dividir } \\
\text { e ser medido } \\
\text { nos dois } \\
\text { anteparos }\end{array}$ & $\begin{array}{l}\text { Se as duas } \\
\text { metades fo } \\
\text { fóton se juntam } \\
\text { como eu posso } \\
\text { ver nos dois } \\
\text { anteparos? }\end{array}$ & $\begin{array}{l}\text { Pergunta de } \\
\text { problematização }\end{array}$ & \\
\hline 082 & $\begin{array}{l}\text { Márcia: (16:15) Eu estava pensando que ali no meio eles } \\
\text { se dividem de novo... }\end{array}$ & & & & $\begin{array}{l}\text { Levantamen } \\
\text { to de } \\
\text { hipótese }\end{array}$ \\
\hline 083 & Professor: Meninos, por favor! & & & & \\
\hline 084 & $\begin{array}{l}\text { Márcia: Vai passar uma parte ali e a outra vai por ali, ó } \\
\text { [aponta a figura] }\end{array}$ & & & & $\begin{array}{l}\text { Teste de } \\
\text { hipótese }\end{array}$ \\
\hline 085 & Professor: Dois que vem pra cá e dois que vem pra cá? & & & & \\
\hline
\end{tabular}




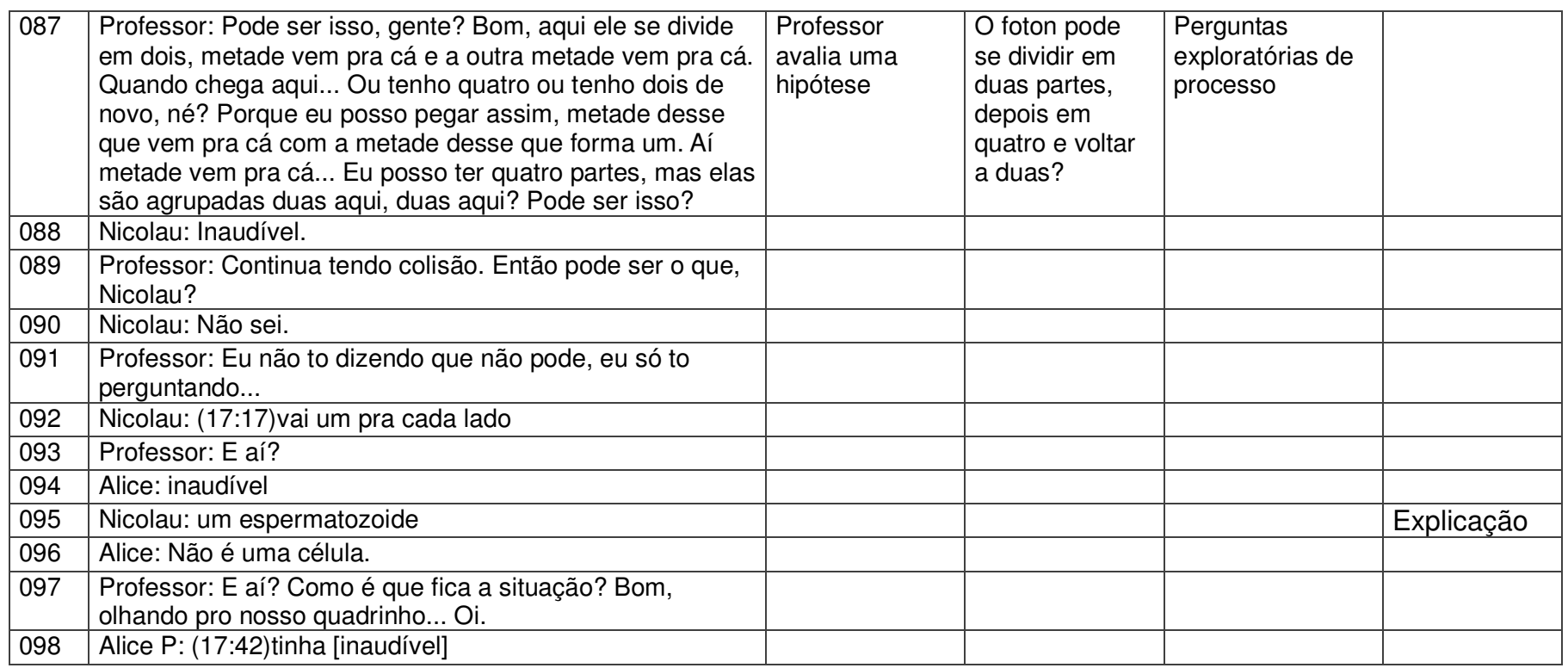

\section{4 - As quatro interpretações da mecânica quântica para a natureza da luz. Professor explora as interpretações junto com os alunos construindo o significado de cada uma.}

\begin{tabular}{|c|c|c|c|c|c|}
\hline $\mathbf{T}$ & Falas transcritas & Descrição & $\begin{array}{c}\text { Reformulando } \\
\text { a pergunta. }\end{array}$ & $\begin{array}{c}\text { Pergunta do } \\
\text { professor }\end{array}$ & $\begin{array}{l}\text { INDICADORES } \\
\text { DE AC }\end{array}$ \\
\hline 100 & Alice: Existem outros? & & & & \\
\hline 102 & Márcia: Ta. & & & & \\
\hline 103 & Professor: Ta né? Porque eu pedi. & & & & \\
\hline 104 & Márcia: Eu já parei. & & & & \\
\hline 105 & $\begin{array}{l}\text { Professor: Já tava com a caneta pronta... Vamos pensar } \\
\text { antes da gente olhar lá o que ta escrito. A gente tem uma } \\
\text { interpretação que recebe o nome de ondulatória. Segundo } \\
\text { essa interpretação a luz é? }\end{array}$ & $\begin{array}{l}\text { Busca dos } \\
\text { alunos o que a } \\
\text { interpretação } \\
\text { ondulatória. }\end{array}$ & $\begin{array}{l}\text { A interpretação } \\
\text { da luz chamada } \\
\text { ondulatória diz } \\
\text { que a luz é...? }\end{array}$ & $\begin{array}{l}\text { Pergunta } \\
\text { exploratória de } \\
\text { processo. }\end{array}$ & \\
\hline 108 & Gilberto: Partícula? Os fótons? & & & & Clasificação \\
\hline 109 & $\begin{array}{l}\text { Professor: São fótons. Fóton é uma partícula de luz. } \\
\text { Existe uma interpretação... Vou pular pra ultima... } \\
\text { Dualista. }\end{array}$ & & & & \\
\hline 110 & Márcia: Ora como onda e como partícula. & & & & $\begin{array}{l}\text { Elaboração } \\
\text { de hipóteses }\end{array}$ \\
\hline 111 & Alice: Onda e Partícula. & & & & $\begin{array}{l}\text { Elaboração } \\
\text { de hipóteses }\end{array}$ \\
\hline 112 & Gilberto: É onda e partícula? & & & & $\begin{array}{l}\text { Elaboração } \\
\text { de hipóteses }\end{array}$ \\
\hline 113 & $\begin{array}{c}\text { Professor: Que ela pode ser as duas coisas ao mesmo } \\
\text { tempo? É uma partícula que é associada com } \\
\text { uma onda ou uma onda com uma partícula... }\end{array}$ & & & & \\
\hline
\end{tabular}




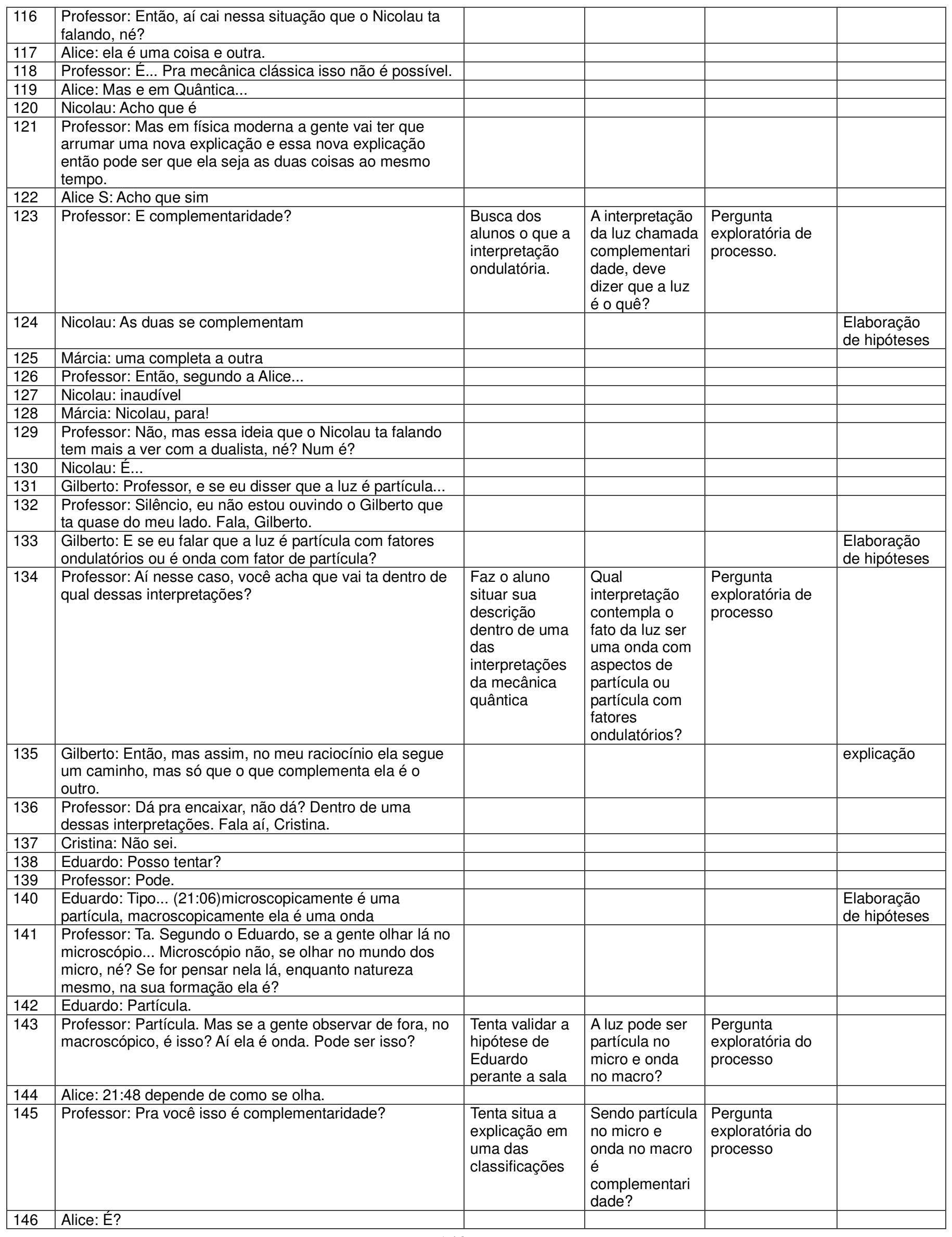




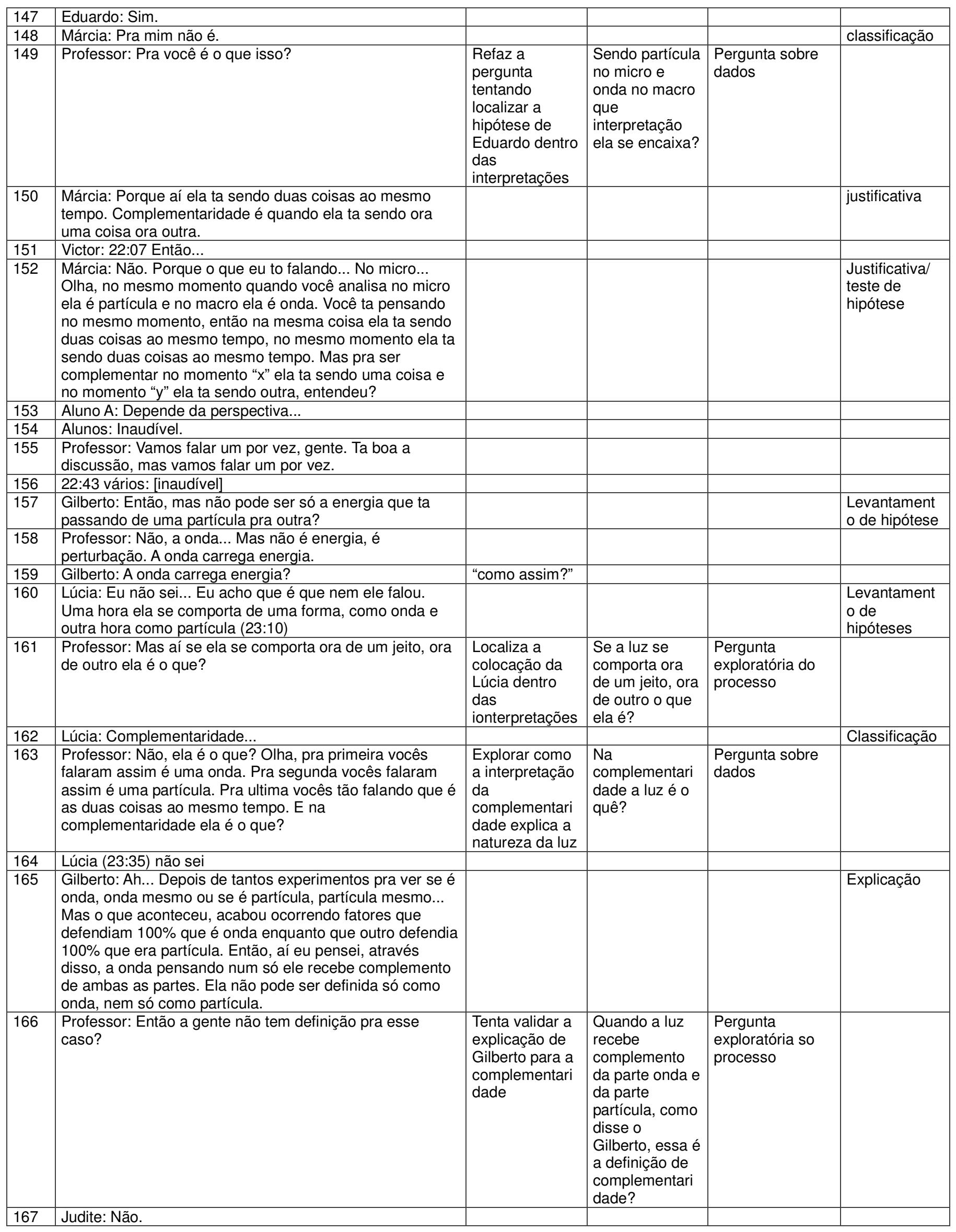




\begin{tabular}{|l|l|l|l|l|}
\hline 168 & Professor: Não sei, to falando pelo Gilberto. & & & \\
\hline 169 & Judite: Vamos passar pra próxima. & & & \\
\hline 170 & Professor: Vamos deixar em branco por enquanto? & & & \\
\hline 171 & Judite: Vamos. & & & \\
\hline 172 & Gilberto: Não & & & \\
\hline 173 & Márcia: Não. & & & \\
\hline
\end{tabular}

\section{5 - As explicações das quatro interpretações para a interferência com apenas um fóton. Professor explora as interpretações junto com os alunos para ver como cada uma delas pode explicar a interferência de um fóton.}

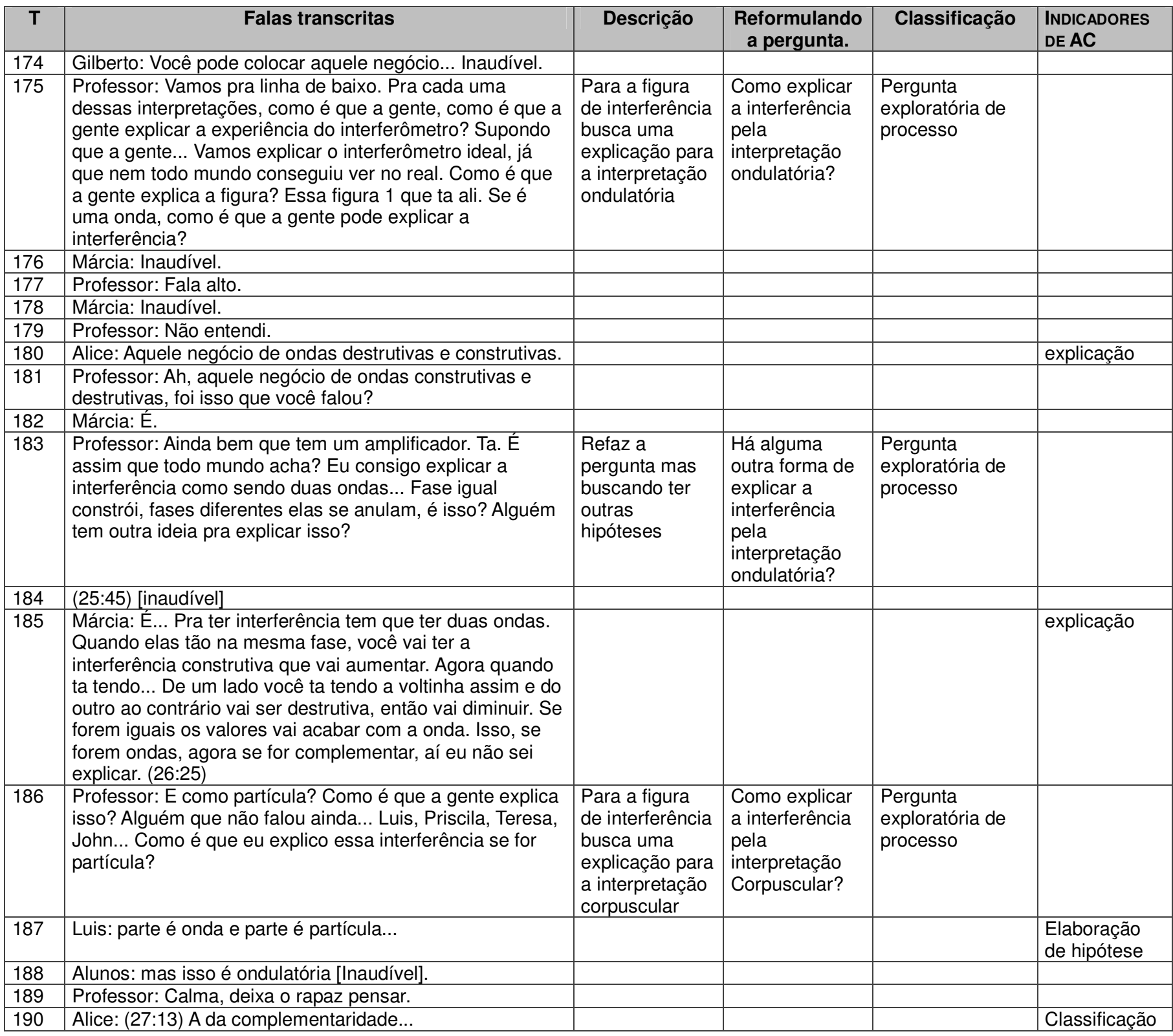




\begin{tabular}{|c|c|c|c|c|c|}
\hline 191 & $\begin{array}{l}\text { Professor: Você ta pulando a pergunta Alice. Se a gente } \\
\text { juntasse a ideia que o Luis ta lançando com o que a Clara } \\
\text { tinha dito a pouco, a ideia da divisão, será que daria pra } \\
\text { explicar? E vamos falar baixo pra não acordar a Zineck. E } \\
\text { aí? Dá pra explicar como... Será que dá? Eu pego a } \\
\text { partícula, quando ela passa ali, ela se divide, depois na } \\
\text { hora que elas se encontram elas vão colidir, se juntam um } \\
\text { pouco, tal... O que a gente tava discutindo antes, aí junta } \\
\text { o que o Luis Tava conversando. Pode ser um caminho? } \\
\text { Pessoas? Fala aí, Carlos! Sem comentários? }\end{array}$ & $\begin{array}{l}\text { Refina a } \\
\text { pergunta } \\
\text { colocando uma } \\
\text { hipótese já } \\
\text { levantada em } \\
\text { aula }\end{array}$ & $\begin{array}{l}\text { Se a particula } \\
\text { se dividir e } \\
\text { interferir, } \\
\text { podemos } \\
\text { explicar a } \\
\text { interferência } \\
\text { assim? }\end{array}$ & $\begin{array}{l}\text { Pergunta } \\
\text { exploratória de } \\
\text { processo }\end{array}$ & \\
\hline 193 & $\begin{array}{l}\text { Professor: Fala aí Clara, o que você queria explicar então } \\
\text { da... Como é que você explica o interferômetro? }\end{array}$ & & & & \\
\hline 194 & Alunos: Inaudível. & & & & \\
\hline 195 & Professor: Fala, Clara. & & & & \\
\hline 196 & Alice: Ele ta falando aqui [inaudível] (28:40) & & & & \\
\hline 197 & $\begin{array}{l}\text { Professor: Não, mas como é que você explica } \\
\text { interferência? }\end{array}$ & & & & \\
\hline 200 & Alice: Não sei... & & & & \\
\hline 201 & Professor: Falem mais. & & & & \\
\hline 202 & Alunos: (29:05) Estamos tentando... & & & & \\
\hline 203 & $\begin{array}{l}\text { Professor: E aí? Ta bom, vamos pro ultimo então. } \\
\text { Dualista-realista. Vocês disseram que... Nossa! }\end{array}$ & & & & \\
\hline 204 & Alunos: Inaudível. & & & & \\
\hline 205 & $\begin{array}{l}\text { Professor: É... Dualista-realista vocês falaram que a luz } \\
\text { era as duas coisas ao mesmo tempo. A interferência } \\
\text { acaba sendo o que? Como é que eu explico a } \\
\text { interferência na dualista? E aí, pessoal? Pra última } \\
\text { interpretação vocês disseram que a luz era as duas coisas } \\
\text { ao mesmo tempo, onda e partícula. }\end{array}$ & $\begin{array}{l}\text { Para a figura } \\
\text { de interferência } \\
\text { busca uma } \\
\text { explicação para } \\
\text { a interpretação } \\
\text { dualista realista }\end{array}$ & $\begin{array}{l}\text { Como explicar } \\
\text { a interferência } \\
\text { pela } \\
\text { interpretação } \\
\text { dualista } \\
\text { realista? }\end{array}$ & $\begin{array}{l}\text { Pergunta } \\
\text { exploratória de } \\
\text { processo }\end{array}$ & \\
\hline 210 & Márcia: 30:20 foton se dividindo & & & & \\
\hline 211 & Professore: Com o que? & & & & \\
\hline 212 & Márcia: Fóton se dividindo. & & & & $\begin{array}{l}\text { Organização } \\
\text { de } \\
\text { informações }\end{array}$ \\
\hline 213 & $\begin{array}{l}\text { Professor: Isso. E depois a colisão deles foi o que o Luis } \\
\text { tinha dito àquela hora. E aí? Se ela é as duas coisas ao } \\
\text { mesmo tempo na quarta interpretação como é que eu } \\
\text { explico a interferência? Ela vai se comportar como o que? }\end{array}$ & $\begin{array}{l}\text { Para a figura } \\
\text { de interferência } \\
\text { busca uma } \\
\text { explicação para } \\
\text { a interpretação } \\
\text { dualista realista }\end{array}$ & $\begin{array}{l}\text { Como explicar } \\
\text { a interferência } \\
\text { pela } \\
\text { interpretação } \\
\text { dualista } \\
\text { realista? }\end{array}$ & $\begin{array}{l}\text { Pergunta } \\
\text { exploratória de } \\
\text { processo }\end{array}$ & \\
\hline 214 & Eduardo: Os dois. & & & & explicação \\
\hline 215 & $\begin{array}{l}\text { Professor: Mas a gente não falou que interferência só } \\
\text { acontece quando tem onda? }\end{array}$ & $\begin{array}{l}\text { Explora a } \\
\text { resposta do } \\
\text { aluno para } \\
\text { problematizar }\end{array}$ & $\begin{array}{l}\text { Se a } \\
\text { interferência só } \\
\text { acontece como } \\
\text { onda e a } \\
\text { interpretação } \\
\text { dualista diz que } \\
\text { a luz é ao } \\
\text { mesmo tempo } \\
\text { onda e } \\
\text { partícula, como } \\
\text { podemos } \\
\text { explicar? }\end{array}$ & $\begin{array}{l}\text { Pergunta de } \\
\text { problematização }\end{array}$ & \\
\hline
\end{tabular}




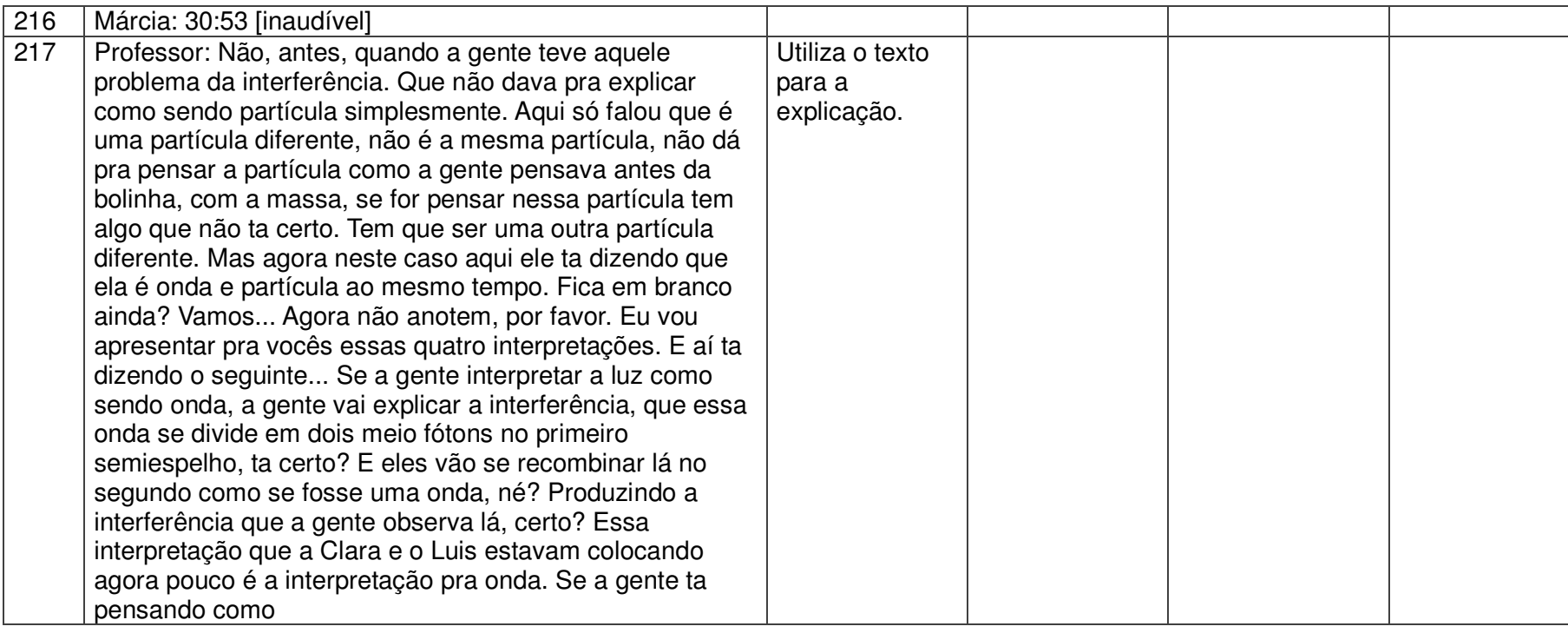

\section{6 - Recorre ao texto para sistematizar as explicações da quatro linhas interpretativas para a interferência de um fóton. Introduz a atividade escrita.}

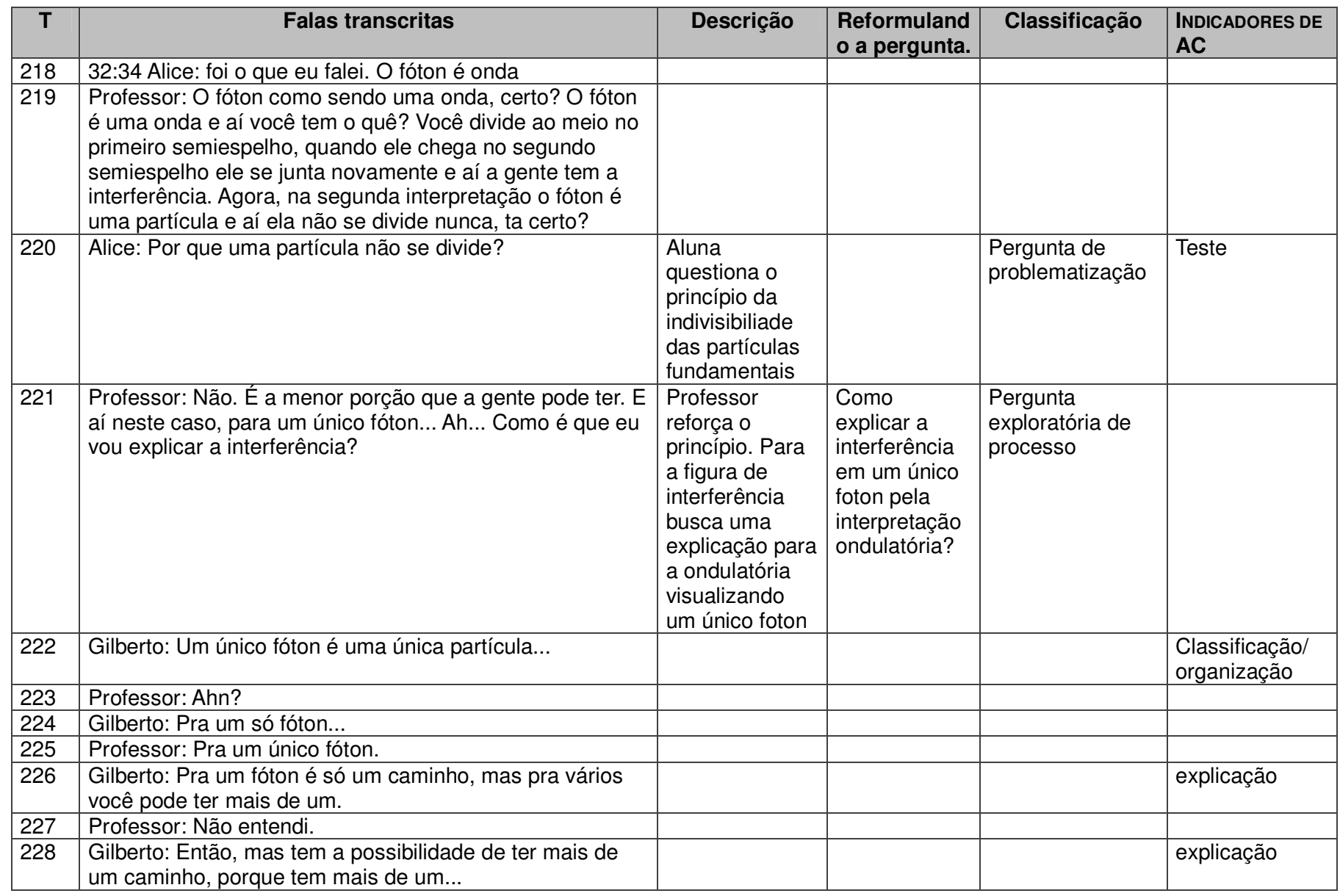




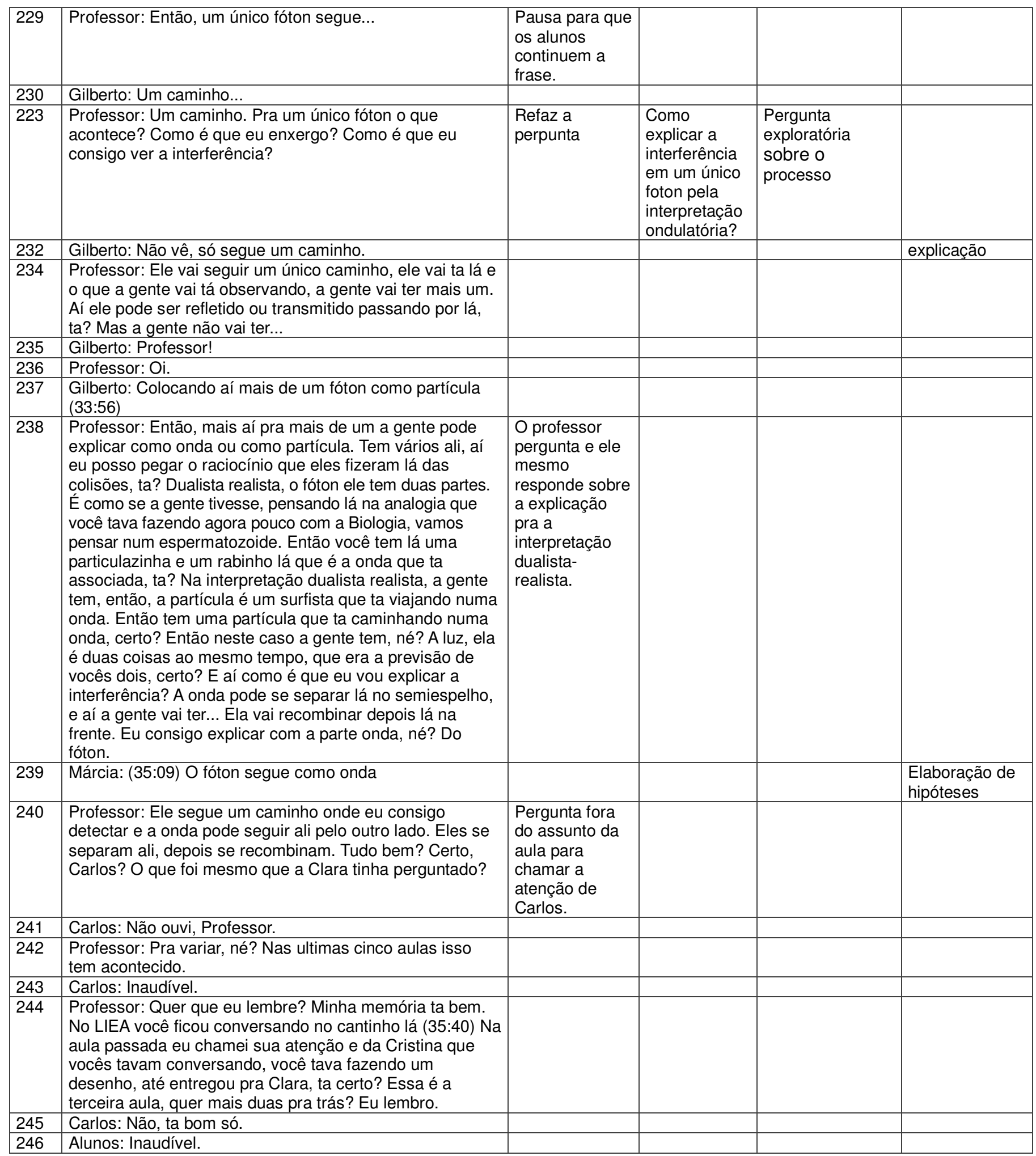


Professor: Gente, interpretação da complementaridade, tá certo? Voltamos às discussões que estavam acontecendo agora pouco, ta? O fóton ora vai se manifestar como onda, ora como partícula, ta certo? Mais nunca ao mesmo tempo. Essa é a diferença que a gente encontra entre os dois. Na dualista realista o fóton é onda e partícula ao mesmo tempo. Eu tenho uma partícula com uma onda associada. Na interpretação da complementaridade, ora é de um jeito, ora de outro. E aí, vocês dois na hora que estavam comentando, né? Fizeram essa discussão. E aí o arranjo que a gente tem ali, a gente tem observação como? Como o que? Como onda e quando a gente põe o detector o que acontece? Ele ta interpretando como partícula, deixa de ter interferência. Na hora que a gente tava fazendo lá a simulação, quando a gente ta observando a interferência, qual é o comportamento que eu to eu to vendo ali da complementaridade? Como onda, certo? Agora, quando eu ponho o detector lá, o que acontece? Vai interagir o detector com o fóton que ta passando. Aquele fóton ali vai ter um comportamento de partícula e aí ele é absorvido ali e a gente não tem mais a interferência. Agora vocês têm que completar aí o quadro e tentar encaixar essas quatro afirmações pra cada uma dessas interpretações. Olha, "precisando de uma nova lógica". Essa interpretação, essa frase, se adéqua a qual dessas interpretações? Ondulatória, corpuscular, complementaridade... "Quando o fóton se divide, quando o fóton decide se é onda ou partícula, só podemos falar na natureza da luz depois que a gente fizer a medição." Essa afirmação é corpuscular, é dualista...

248 Márcia: (38:14) é complementaridade

249 Professor: Ahn? Não, isso vocês só vão responder pra mim. No papel vocês vão colocar só essas questões que tão. Agora aqui...

\begin{tabular}{|l|l|}
\hline 250 & Alice: A segunda é complementaridade. \\
\hline 251 & Professor: Todo mundo concorda que a segunda é
\end{tabular}

251 Professor: Todo mundo concorda que a segunda é complementaridade?

252 Luis: Sim.

253 Professor: Eu só posso falar da natureza da luz depois que eu fizer a medição?

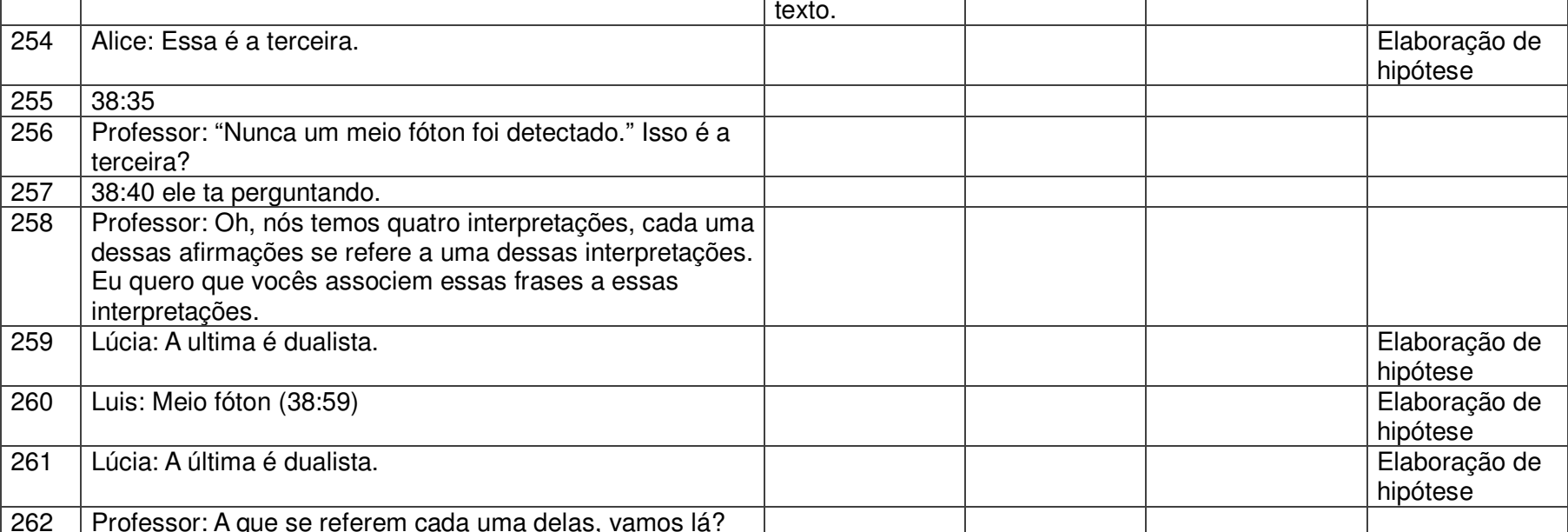




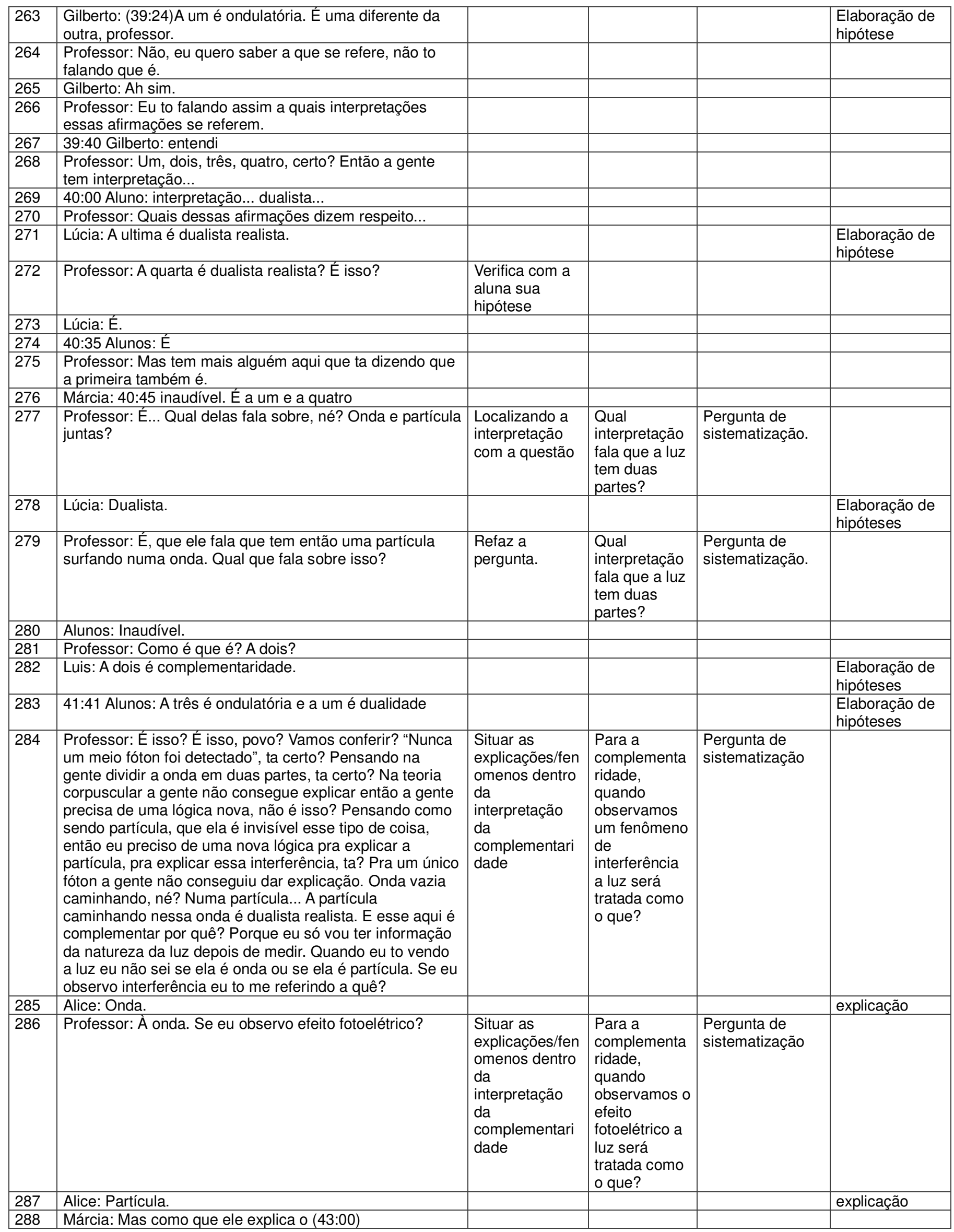




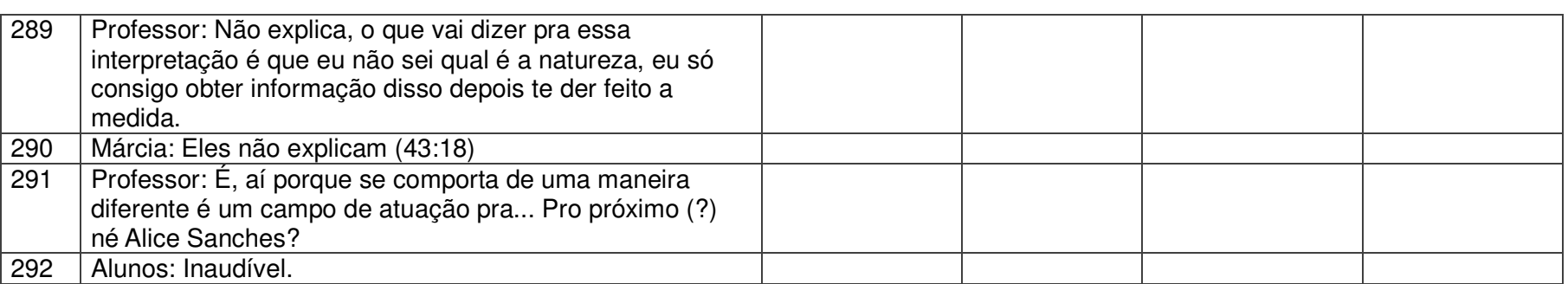

